\title{
Naropini Stichel, taxonomia e imaturos (Lepidoptera, Nymphalidae, Brassolinae) ${ }^{1}$
}

\author{
Mirna M. Casagrande ${ }^{2}$
}

\begin{abstract}
Naropini Stichel, taxonomy and immatures (Lepidoptera, Nymphalidae, Brassolinae). A systematic study of Naropini (Stichel, 1925) Casagrande, 1996 is presented. The species of this tribe occur exclusively in the Neotropical Region. All the known species of Aponarope Casagrande, 1982, and Narope Doubleday, [1849] are redescribed, new species are described and all of them are illustrated Immatures of Narope cyllene C. Felder \& R. Felder, 1859 are redescribed. Head chaetotaxy of the first instar larva is illustrated with electron micrographies. Both, the head and body chaetotaxy of this instar is also interpreted. The following are new species: Narope minor Casagrande, Oaxaca, Mexico; Panama, Veraguas, Panama; San Jose, Costa Rica. - Narope obidos Casagrande, Pará, Mato Grosso, Espírito Santo, Brazil; Madre de Dios, Peru. - Narope ybyra Casagrande, Bolivia. - Narope cauca Casagrande, Cauca Valley, ColombiA. Lectotypes are designated for the following species or subspecies: Narope cyllastros Doubleday, [1849]; Narope cyllarus Westwood, 1851; Narope panniculus piccatus Stichel, 1916; Narope nesope Hewitson, 1869; Narope testacea Godman \& Salvin, 1878; Narope cyllabarus Westwood, 1851; Narope anartes Hewitson, 1874; Narope marmorata Schaus, 1902, and Narope pluto Tessmann, 1928. Narope denticulatus Talbot, 1928 is a stat. n. Narope syllabus stygius Staudinger, 1887 is a ssp. rev., comb. n. Narope testacea Godman \& Salvin, 1878 is a stat. rev. Narope marmorata Shaus, 1902 is a stat. rev. The following are syn. n.: Narope pusilla Röber, 1929 of Narope nesope Hewitson, 1869; Narope sarastro Staudinger (1886) and Narope sarastro disyllus Fruhstorfer, 1912 of Narope anartes Hewitson, 1874, and Narope panniculus piccata Stichel, 1916 of Narope panniculus Stichel, 1904.
\end{abstract}

KEY WORDS. Lepidoptera, Neotropical, Brassolinae, Narope, Aponarope

\section{CONTEÚDO}

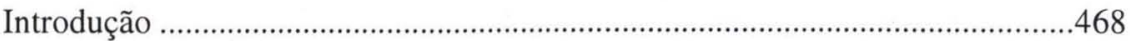

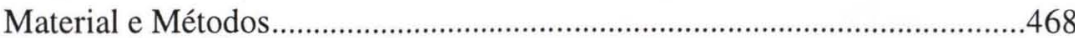

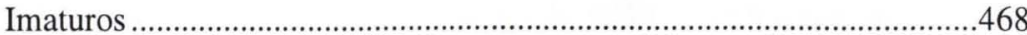

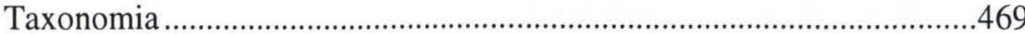

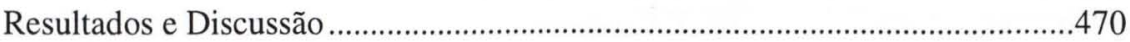

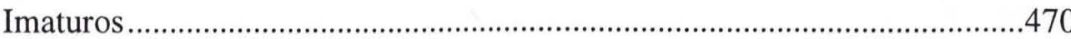

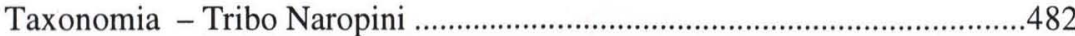

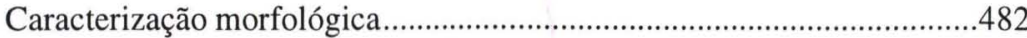

Chave para os gêneros de Naropini ..............................................................483

1) Contribuição número 1290 do Departamento de Zoologia, Universidade Federal do Paraná

2) Departamento de Zoologia, Universidade Federal do Paraná. Caixa Postal 19020, 81531-980 Curitiba, Paraná, Brasil. Pesquisador CNPq. E-mail: mibras @ bio.ufpr.br 
Narope 483

Caracterização morfológica 484

Espécies e subespécies incluídas .......................................................... 487

Chave para identificação de machos das espécies de Narope ........... 488

Chave para identificação de fêmeas das espécies de Narope ............ 489

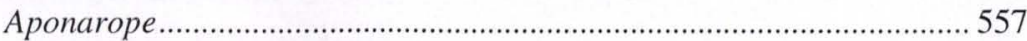

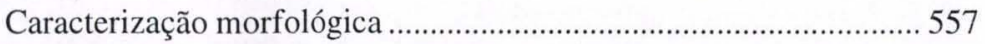

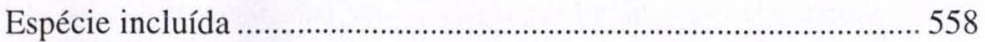

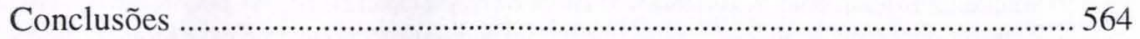

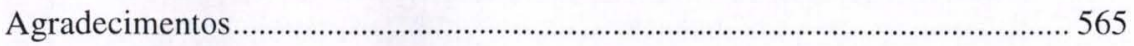

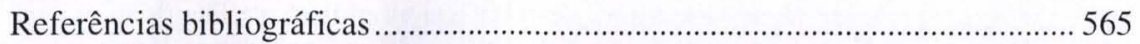

A subfamília Brassolinae (Boisduval, 1836) Bates, 1861 é exclusivamente Neotropical, sendo seu limite sul o norte da Argentina, Paraguai e Bolívia. Como interpretada por CASAGRANDE (1996), possue duas tribos: Brassolini (Boisduval, 1836) Handlirsch, 1925 com os gêneros: Brassolis Fabricius, 1807; Caligo Hübner, 1819; Penetes Doubleday, [1849]; Dynastor Doubleday, [1849]; Opsiphanes Doubleday, [1849]; Dasyophthalma Westwood, 1851; Eryphanis Boisduval, 1870; Opoptera Aurivillius, 1882; Selenophanes Staudinger, 1887; Catoblepia Stichel, 1902; Caligopsis Seydel, 1924; Mielkella Casagrande, 1982; Orobrassolis Casagrande, 1982 e Mimoblepia Casagrande, 1982; enquanto Naropini (Stichel, 1925) Casagrande, 1996 dois gêneros: Narope Doubleday, 1849 e Aponarope Casagrande, 1986.

A monofilia da subfamília está baseada no uso de monocotiledôneas como planta hospedeira das larvas, na presença de célula e veia umerais, célula discal fechada em ambas as asas e pelas androcônias e pincéis de pêlos nas asas.

Os Naropini, ao contrário da tribo Brassolini, não possuem valor comercial, pois são pequenos e quase todos de cores escuras ou ferrugíneo. Também são pouco coletados porque voam no crepúsculo e de forma tão rápida que são de difícil visualização, como sugere a etimologia do nome Narope - "como corredeira", razão pela qual, nas coleções encontram-se poucos representantes. São habitantes de florestas e somente encontrados em áreas abertas, sobre restos de animais ou frutas em decomposição.

A proposta desse estudo objetiva um melhor conhecimento dos aspectos morfológicos, de distribuições temporal e espacial das espécies e subespécies, comparações com material tipo e um aprofundamento de dados sobre os imaturos e sistemático.

\section{MATERIAL E MÉTODOS}

\section{Imaturos}

Para os dados de oviposição, estudos morfológicos e período de desenvolvimento dos imaturos, utilizou-se uma fêmea de Narope cyllene C. Felder \& R. Felder, 1859 coletada em Rio Vermelho, São Bento do Sul, Santa Catarina, que foi colocada sobre Chusquea leptophylla Nees (Poaceae), planta hospedeira. 
Ovos, larvas e pupas foram mantidos na planta hospedeira até a emergência dos adultos. Um exemplar de cada fase do desenvolvimento foi fixado em Dietrich por 72 horas e posteriormente conservado em álcool $70 \%$.

Os desenhos foram feitos com auxílio de câmara clara (Wild M5), as fotos em microscopia eletrônica de varredura (Philips SEM 505) e metalizador (Balzers SCD 030).

A nomenclatura relacionada às áreas do corpo está baseada em PETERSON (1962) e a quetotaxia em HINTON (1946), PETERSON (1962) e STEHR (1987).

\section{Taxonomia}

Estudou-se, incluindo todos os holótipos e lectótipos aqui designados, aproximadamente 800 exemplares, sendo $50 \%$ da Coleção Pe. Jesus Santiago Moure, Departamento de Zoologia, Setor de Ciências Biológicas da Universidade Federal do Paraná, uma das coleções com maior representatividade da tribo.

Exemplares quando não da referida coleção, foram solicitados por empréstimo ou mesmo estudados na própria instituição, conforme relação que segue com os respectivos curadores. As abreviaturas utilizadas estão de acordo com HEPPNER \& LAMAS (1982) e MIELKE (1995). (AMNH) American Museum of Natural History, Nova Iorque, EUA. Drs Frederick Rindge e James Miller; (AME) Allyn Museum of Entomology, Sarasota, Florida, EUA. Drs. Lee Miller e Jacqueline Miller; $(\mathrm{BM}(\mathrm{NH}))$ The Natural History Museum, Londres, Inglaterra. Drs. R.I. VaneWright e Phillip Ackery; (CGCM) Coleção particular do MsC. Carlos Guilherme Costa Mielke, Curitiba, Paraná, Brasil; (CU) Department of Entomology, Cornell University, Ithaca, New York, USA, Dr. John G. Franclemont; (EF) Coleção particular do Sr. Eurides Furtado, Diamantino, Mato Grosso, Brasil; (ESM) Coleção particular do Dr. Ernst Schmidt-Mumm, Bogotá, Colômbia; (FR) Coleção particular do Sr. Francisco Romero, Maracay, Venezuela; (IBGE) Coleção da Reserva Ecológica do Instituto Brasileiro de Geografia e Estatística (IBGE), Brasília, Distrito Federal, Brasil. Dr. Braulio Dias; (IOC) Instituto Oswaldo Cruz, Rio de Janeiro, Rio de Janeiro, Brasil, Sr. Orlando Ferreira; (KB) Coleção Particular do Dr. Keith Brown Jr., Campinas, São Paulo, Brasil; (MHNL) Museo de Historia Natural, Lima, Peru, Dr. Gerardo Lamas; (MNHP) Muséum National d'Histoire Naturelle, Paris, França, Drs Pierre Viette, G. Bernardi, Jacques Pierre e Judith Najt; (MNRJ) Museu Nacional, Universidade Federal do Rio de Janeiro, Rio de Janeiro, Brasil, Drs. Alfredo R. do Rego Barros e Luiz Soledade Otero; (MZSP) Museu de Zoologia, Universidade de São Paulo, São Paulo, Brasil, (inclui a Coleção Diringshofen), Dr. Ubirajara Martins; (NT) Coleção particular do Sr. Nirton Tangerini, Rio de Janeiro, Rio de Janeiro, Brasil; (OM) Coleção particular do Dr. Olaf H.H. Mielke, Curitiba, Paraná, Brasil; (SMTD) Staatliches Museum für Tierkunde, Dresden, Alemanha, Dr. R. Krause; (UCV) Departamento de Zoologia Agricola, Facultad de Agronomia, Universidad Central de Venezuela, Maracay, Venezuela, Dr. Luiz D. Otero; (UFP) Departamento de Entomologia, Universidade Federal de Pelotas, Rio Grande do Sul, Brasil (Coleção C.M. Biezanko), Dr. Milton de Souza Guerra; (UFPC) Departamento de Zoologia, Setor de Ciências Biológicas, Universidade Federal do Paraná, Curitiba, Paraná, Brasil, (inclui as coleções: R.F. D’Almeida, P. Gagarin, H. Ebert, 
D. Gifford); (USNM) National Museum of Natural History, Smithsonian Institution, Washington, EUA, Dr. Robert K. Robbins; (ZMHB) Zoologisches Museum der Humboldt Universität, Berlim, Alemanha, Drs H.J. Hannemann e W. Mey; (ZMUC) Zoologisk Museum, Copenhague, Dinamarca, Dr. Niels P. Kristensen; (ZSBS) Zoologische Sammlung des bayrischen Staates, Munique, Alemanha, Dr. W. Dierl.

Para todas as espécies examinou-se o material tipo, nas respectivas coleções onde estão depositados e foram feitos slides em vistas dorsal, ventral e etiquetas.

No catálogo que segue a cada gênero, espécie ou subespécie cita-se, de que assunto trata a referência, para qual, utilizam-se as seguintes abreviaturas: (biol.) biologia, (cat.) catálogo, (cit.) citação, (d) dorsal, (dg) distribuição geográfica, (etol.) etologia, (planta hosp.) planta hospedeira, (sist.) sistemática, (v) ventral.

Para os estudos morfológicos de cada espécie preparou-se, sempre que possível, vários exemplares em ambos os sexos. As genitálias e apêndices, como pernas, antenas e palpos, foram fervidos em banho-maria em solução de hidróxido de potássio, e quando moles, lavadas em água e retiradas todas as escamas e no caso da genitália, as estruturas membranosas internas. Após interpretação, os preparados foram devidamente etiquetados e preservados em tubos de vidro com glicerina juntamente com o exemplar, nas gavetas entomológicas. Para as venações utilizouse clareamento em hipoclorito de sódio diluído a $20 \%$ (água sanitária comercial), após rápida imersão em álcool comercial para remoção das gorduras. Após secagem entre papel absorvente e vidros, foram coladas no exemplar.

Nos desenhos de venações incluiu-se os padrões de faixas e manchas objetivando facilitar a identificação (Fig. 27). Para as medidas das asas utilizou-se os seguintes critérios: asa anterior - comprimento da margem costal (base da asa até o ápice de $\mathrm{R}_{4}$ ); margem externa ( $\mathrm{R}_{3}$ até $2 \mathrm{~A}$ ); largura da asa (ápice de $\mathrm{R}_{2}$ até ápice de 2A). Asa posterior - comprimento da margem costal (base até ápice de Rs); margem externa (Rs até o ângulo anal em $2 \mathrm{~A}$ ); maior comprimento da asa (base até o ápice de $\mathrm{CuA}_{1}$ e em Aponarope sutor, Narope nesope, Narope obidos $\mathbf{s p .} \mathbf{n}$. e Narope cyllabarus, da base até o ápice de $2 \mathrm{~A}$ ).

Etiquetou-se todos os exemplares com etiquetas de identificação e os holótipos, alótipos e parátipos das espécies e subespécies novas ou já descritas, assim como os lectótipos e paralectótipos designados conforme padrões internacionais.

Nas distribuições espacial e temporal somente considerou-se as procedências de exemplares examinados e alguns dados bibliográficos confiáveis. Nos mapas de distribuição espacial, os sinais vazados, indicam procedências sem definição de estado, província ou departamento. (1995).

Algumas datas de publicações foram atualizadas conforme LAMAS et al.

\section{RESULTADOS E DISCUSSÕES}

\section{Imaturos (Figs 1-19)}

Entre os Nymphalidae, os Brassolinae são conhecidos pelos hábitos crepusculares e pelo impacto econômico que algumas espécies podem causar, como é o caso de Brassolis astyra Godart, [1824], Brassolis sophorae (Linnaeus, 1758) e 
Brassolis isthmia Bates, 1864 ou ainda Caligo eurilochus (Cramer, 1775) e Caligo memnon (C. Felder \& R. Felder, 1867), em todos estes casos como devoradores vorazes, estes de folhas de bananeiras e aqueles de folhas de palmeiras em geral. Entre os Brassolis, que têm hábitos gregários, construíndo ninhos algumas vezes com centenas de larvas, o impacto é ainda maior.

PENZ et al. (2000), em relato sobre as plantas alimentícias da subfamília, indicam a preferência das espécies por monocotiledôneas como também já citado por EHRLICH \& RAVEN (1965) e ACKERY (1988). Essas preferências variam dentro dos distintos gêneros por Arecaceae, Poaceae, Musaceae, Cannaceae, Marantaceae, Zingiberaceae e Bromeliaceae.

Estudos sobre espécies que não se constituem pragas em potencial, como os relatados por CASAGRANDE (1979, 1991 e 2000) para Caligo beltrao (Illiger, 1801); Narope cyllene $\mathrm{C}$. Felder \& R. Felder, 1859; Dasyophthalma rusina rusina (Godart, [1824]); Caligo martia (Godart, [1824]); DIAS (1979), para Eryphanis automedon automedon (Cramer, 1776) (citado como seu sinônimo, Eryphanis polyxena polyxena (Meerburgh, [1780]) EMMEL (1991), para Dynastor napoleon Doubleday, [1849] e URICH \& EMMEL (1991) para Dynastor darius darius (Fabricius, 1775), têm contribuído para a sistemática destes gêneros.

Especificamente para o gênero Narope Doubleday [1849] poucos são os dados, exceto por aqueles citados por MÜLLER (1886); BATES (1932); SILVA et. al. (1967-1968), DEVRIES (1987) e ACKERY (1988) que relatam poucos aspectos e na grande maioria só relacionados com a planta hospedeira. CASAGRANDE (1991) ao revalidar e redescrever Narope cyllene C. Felder \& R. Felder, 1859, descreve e figura os imaturos.

Neste artigo redescreve-se e complementam-se estes dados com fotografias de microscopia eletrônica da cabeça de primeiro estádio, interpretação de parte da quetotaxia da cabeça e do corpo da larva de primeiro estádio.

\section{Oviposição (Fig. 1)}

Uma fêmea de Narope cyllene C. Felder \& R. Felder, 1859, capturada em Rio Vermelho, São Bento do Sul, Santa Catarina, 850 m, próxima à uma área com predominância de Chusquea leptophylla Nees (Poaceae), bambu, foi trazida ao laboratório, onde induziu-se à postura, colocando-a sobre a suposta planta hospedeira envolta por saco plástico transparente.

Durante três dias, a fêmea ovipositou um total de 36 ovos, nas axilas das folhas sendo apenas um na face adaxial da mesma. Os ovos são presos às folhas por substância transparente misturada com algumas escamas.

\section{Ovo (Fig. 2)}

Pouco mais alto que largo, $1 \mathrm{~mm}$ de diâmetro por $1,2 \mathrm{~mm}$ de altura. Branco amarelado, com linhas longitudinais ligadas por fino reticulado. Vinte e quatro horas após a postura, podem ser visualizadas bandas avermelhadas no pólo superior ao redor da área micropilar. Este vermelho se intensifica até quase próximo à eclosão da larva, quando pode ser observada pela transparência do cório.

A eclosão das larvas ocorreu no final de março, oito dias após a postura dos primeiros ovos. 

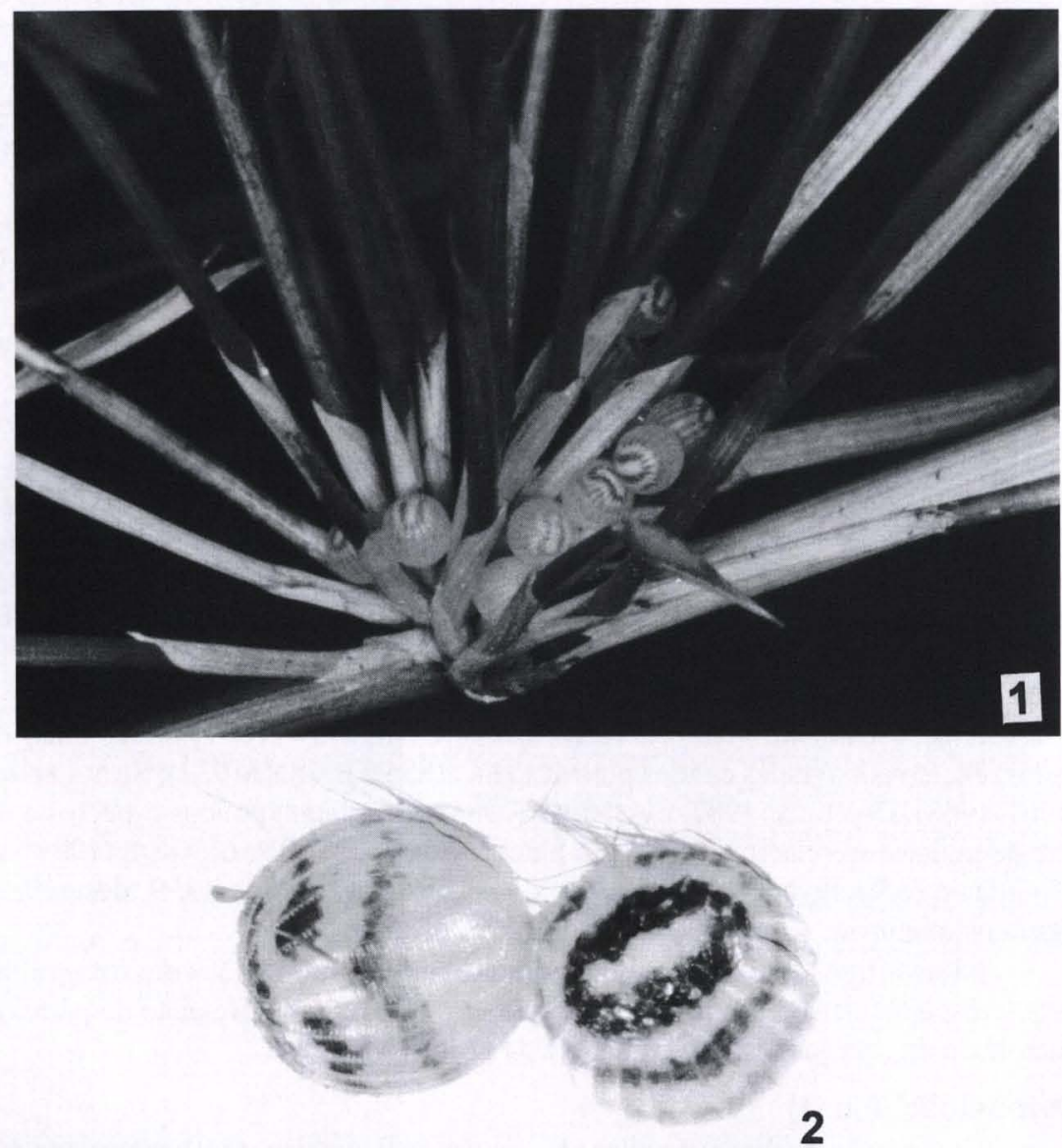

Figs 1-2. Narope cyllene. (1) Aspecto da postura; (2) ovo.

\section{Larva de primeiro estádio (Figs 3A, 4-13)}

Logo após a eclosão, alimentam-se do cório do próprio ovo ou de outros já abandonados. Percorrem ativamente sobre as folhas e caule da planta, até iniciarem a alimentação com as folhas, aproximadamente doze horas após a eclosão.

Cabeça: sem escolos, arredondada e de textura irregular, castanho escura translúcida (Fig. 13). As cerdas são escuras na base, claras e ramificadas na parte distal. Mandíbulas retangulares, com extremidade cortante reta (Fig. 5). Fiandeira de extremidade bífida, com as pontas cruzadas sobre si. Palpos labiais, laterais e pouco anteriores à fiandeira (Figs 6 e 7). Conjunto de seis estemas, os quatro primeiros distribuídos em semicirculo e em posição lateral, o quinto ventral e ao lado externo da antena e o sexto também ventral, pouco além do quinto (Fig. 8). 

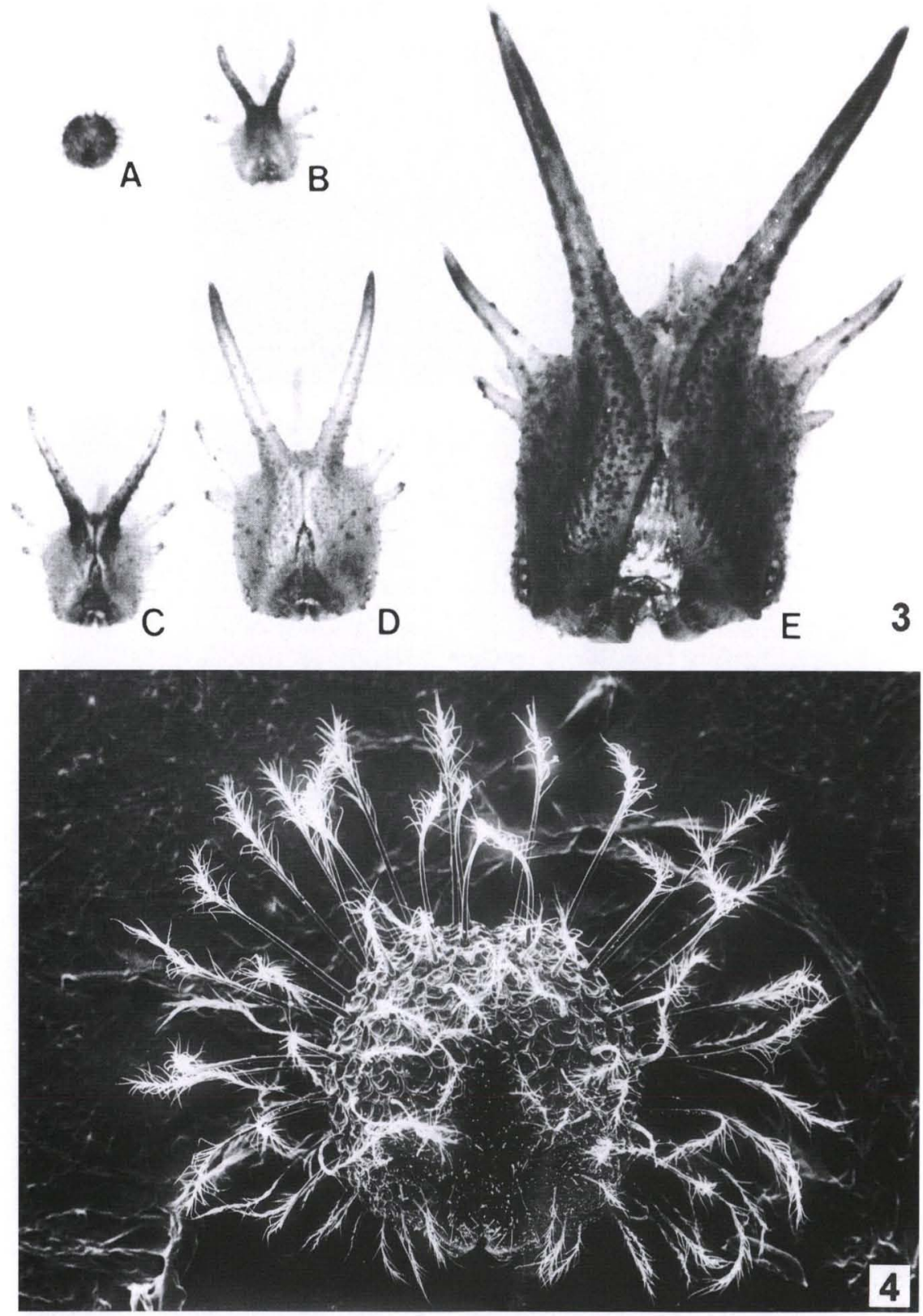

Figs 3-4. Narope cyllene. (3) Cabeça, vista frontal: (A a E) larvas de primeiro ao quinto estádio respectivamente; (4) larva de primeiro estádio. 

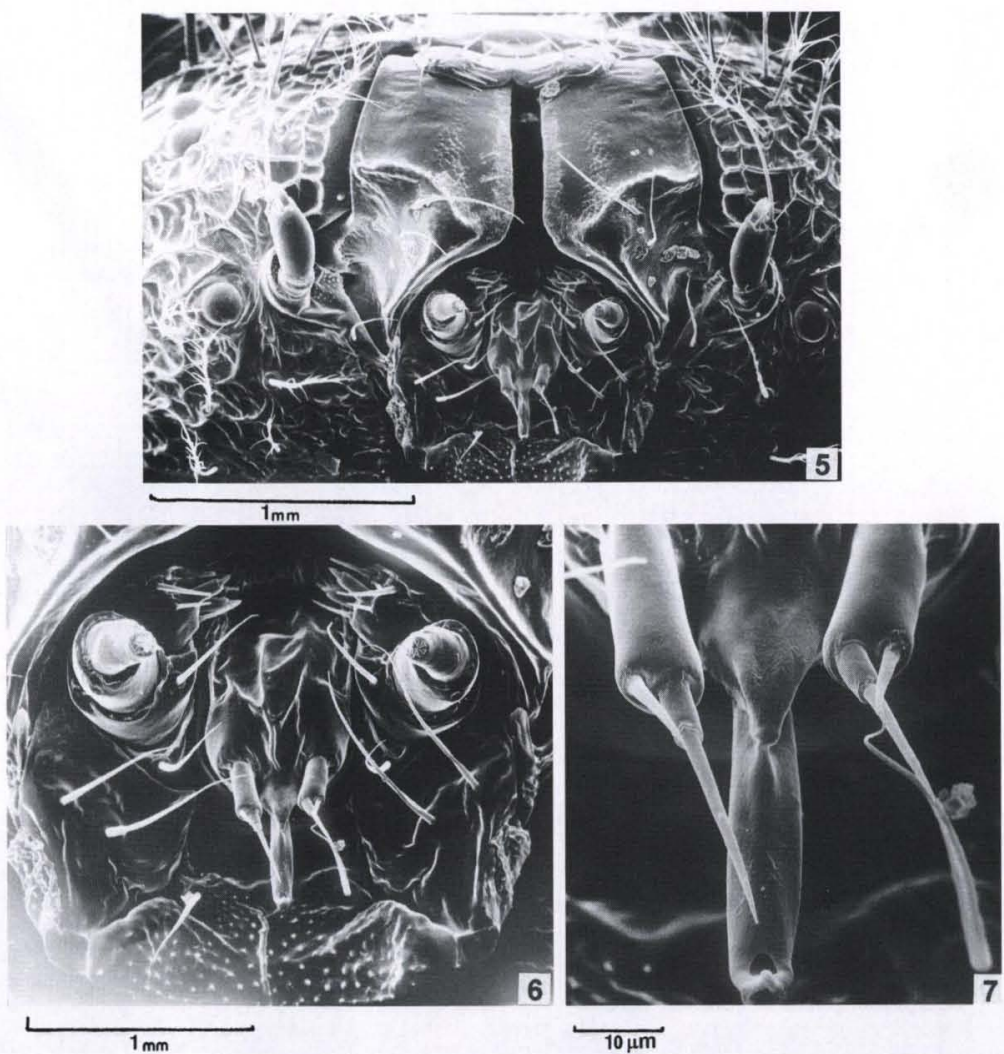

Figs 5-7. Narope cyllene, cabeça, vista ventral. (5) Mandíbula; (6) palpo maxilar; (7A) palpo labial; (7B) fiandeira.

Além da fiandeira, em posição distal, ainda dentro da fossa proboscidial, tecido corrugado de pontuações claras (Figs 5 e 6). Este mesmo aspecto pode ser encontrado na base das antenas (Fig. 9) e ao redor do forame magno, exceto na parte ventral, cujo limite é feito por duas pregas crenuladas (Figs 10 e 11).

\section{Quetotaxia da cabeça (Fig. 12)}

Encontrou-se três tipos de cerdas. Um primeiro grupo de cerdas grandes e ramificadas a partir da metade distal; um segundo grupo, de aspecto morfológico igual às anteriores, porém com a metade do tamanho, intercaladas entre estas e, um terceiro grupo de cerdas pequenas e sem ramificações, distribuídas pela fronte, clipeo, labro, palpo maxilar e mandíbulas. Não identificou-se nenhuma pontuação, uma hipótese para esta dificuldade em visualizar estas estruturas pode estar relacionada ao processo de metalização para microscopia eletrônica de varredura, como já observado em experimentos anteriores, com formas imaturas de Lycaenidae (DUARTE in litt.). 

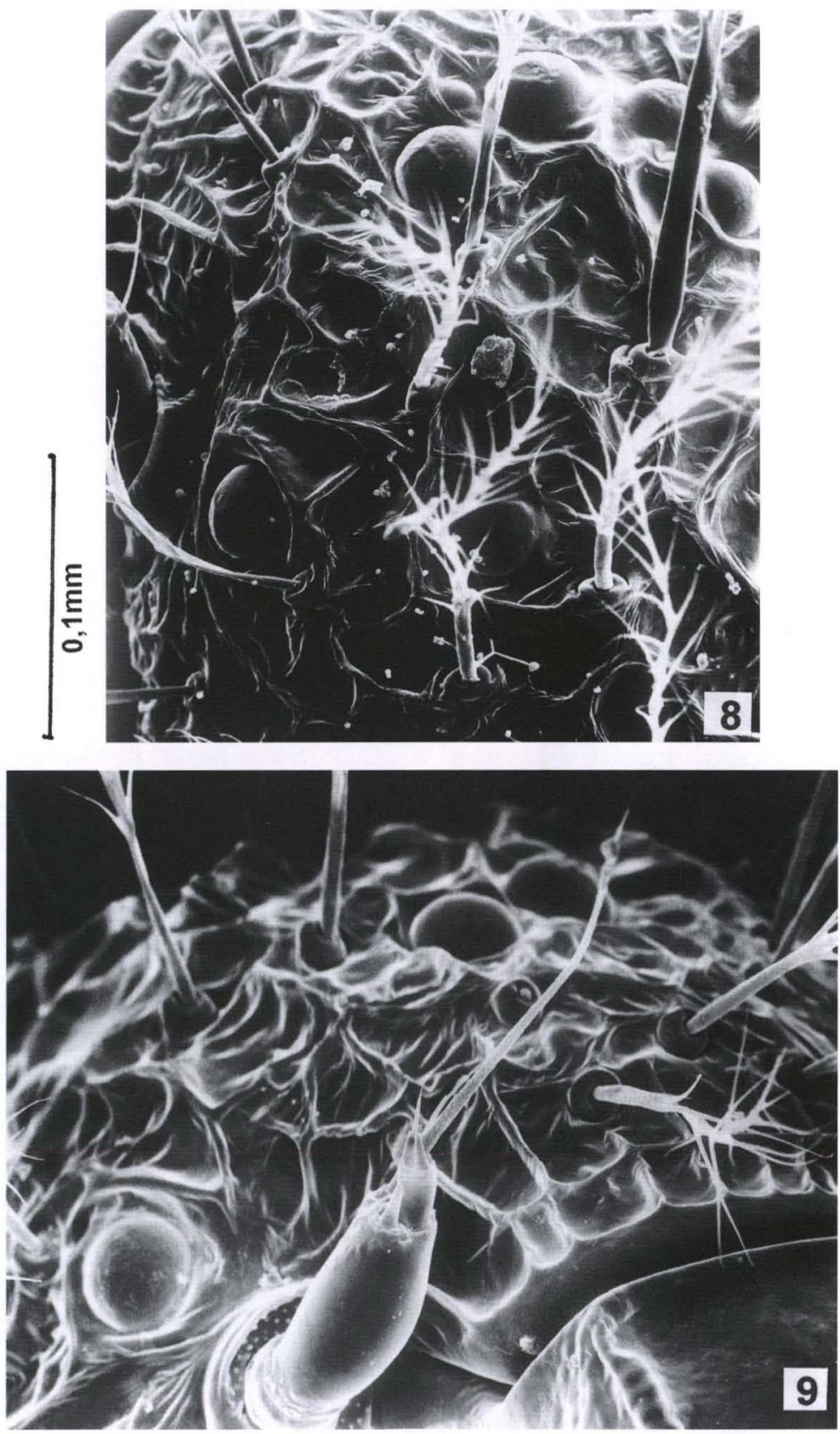

Figs 8-9. Narope cyllene. (8) Conjunto de estemas; (9) antena. 

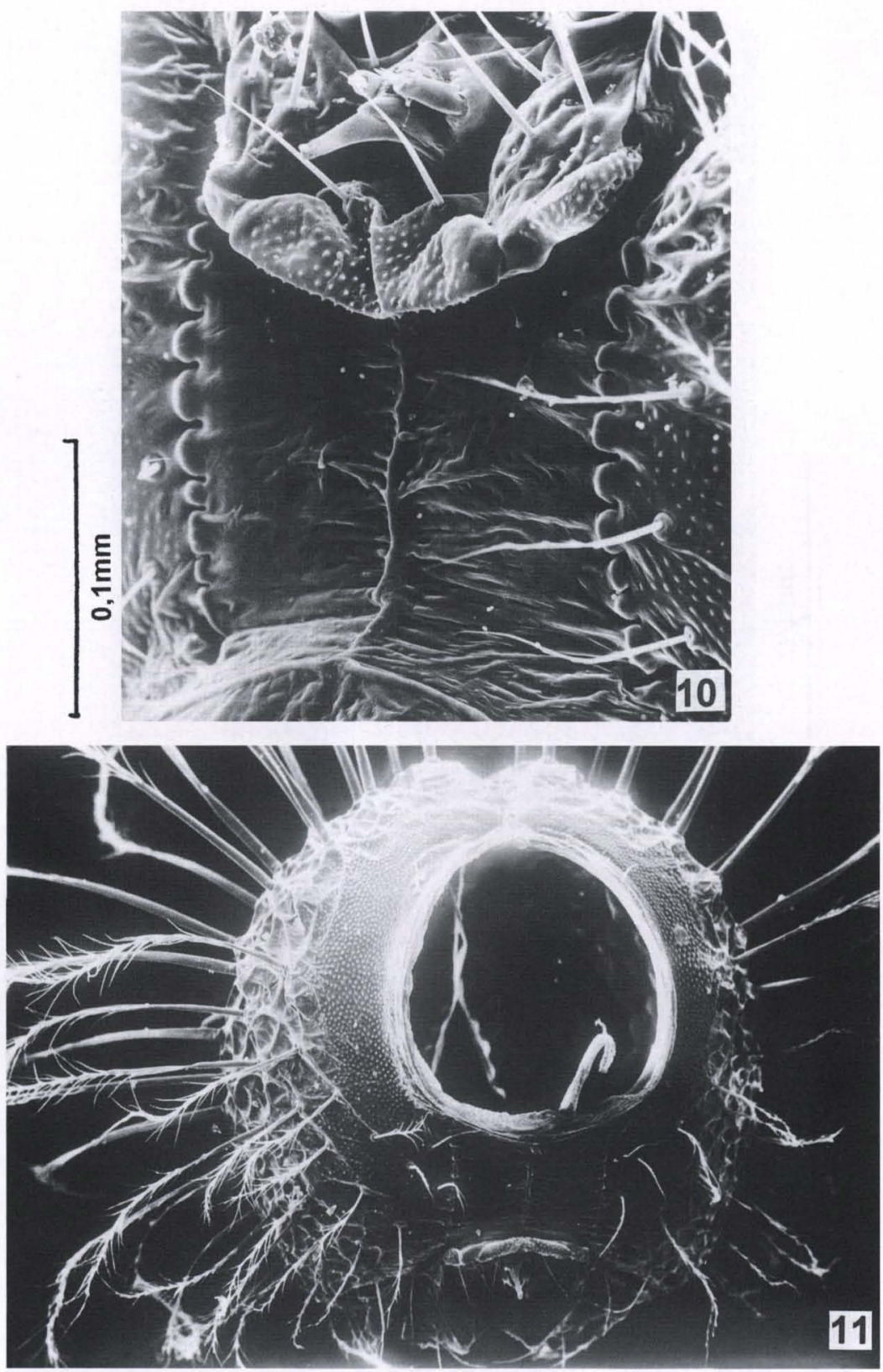

$0,5 \mathrm{~mm}$

Figs 10-11. Narope cyllene, cabeça. (10) Vista ventral; (11) vista posterior.

Revta bras. Zool. 19 (2): 467 - 569, 2002 


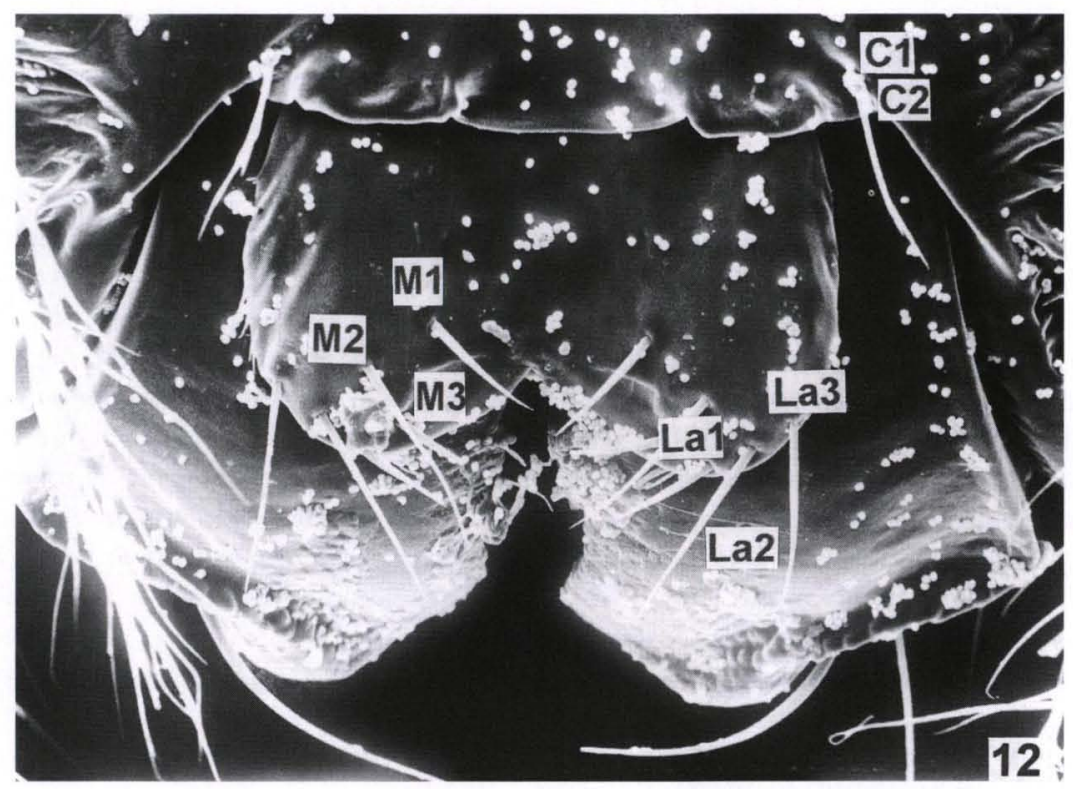

$0.1 \mathrm{~mm}$

Fig. 12. Narope cyllene, cabeça: clípeo, labro e mandíbula.

HINTON (1946), PETERSON (1962) e STEHR (1987) identificam para a fronte apenas um par de cerdas, denominada $\mathrm{F}_{1}$, em posição lateral e inferior, próximo ao labro. No clípeo, $\mathrm{C}_{1}$ e $\mathrm{C}_{2}$ ambas em posição lateral. $\mathrm{C}_{1}$ sobrepondo-se a $\mathrm{C}_{2}$ (Fig. 12). No labro, apenas PETERSON (1962) considera e identifica as cerdas desta estrutura. São facilmente visualizadas os três pares de medianas como $\mathrm{M}_{1}, \mathrm{M}_{2}$ e $\mathrm{M}_{3}$ onde $\mathrm{M}_{2}$ cobre parcialmente $\mathrm{M}_{3}$ e três pares de laterais, $\mathrm{L}_{1}, \mathrm{~L}_{2}$ e $\mathrm{L}_{3}$ (Fig. 12).

Tórax e abdome: de coloração amarelo-palha com três faixas longitudinais vermelhas. A primeira, média dorsal, a segunda supra-espiracular e a terceira, sub-espiracular, com início no mesotórax e término no final do abdome. Entre essas faixas, sobre a segunda e abaixo da terceira, faixas longitudinais branco-leitosas.

Sobre a média dorsal, no quarto segmento abdominal, esta faixa é pouco difusa, dando lugar a uma mancha alongada também vermelha. Face ventral verde claro e à partir do primeiro segmento abdominal, com faixa vermelha na linha mediana.

Placa suranal bífida, com projeções bege (Fig. 13).

Alimentam-se tanto pela manhã, como ao entardecer. Permanecem isoladas na face adaxial ou abaxial das folhas e praticamente imóveis durante todo o dia.

\section{Quetotaxia do tórax (Figs 18 e 19)}

Entre todos os segmentos do corpo, o protórax possui o maior nụ́mero de cerdas. Sobre a placa protorácica (Fig. 19A) estão as cerdas táteis XD1, XD2, D1 e D2, todas de igual tamanho. XD1 e XD2 em posição proximal, enquanto D1 e D2 
pouco mais caudal. O conjunto de L1, L2 e L3, na mesma linha do espiráculo e anteriores a este, sendo L1 pouco maior que as outras. SD1 e SD2 acima do espiráculo. No meso e metatórax, presentes D1 e SD1 alinhadas anteriormente, ausência de L3 e aparecimento de SV1 logo após a coxa.

No abdome, A1 e A2, com o mesmo padrão: D1 e SD1 com o mesmo tamanho, sendo SD1 posterior à D1; L1 acima e posterior ao espiráculo enquanto L2 está abaixo e anterior ao mesmo. SV1 e SV2 posteriores à L2. A3 a A7: com D1 na mesma posição de A1 e A2, seguida em posição caudal e inferior de D2; inferior à D1 e D2, em uma linha imaginária entre essas, está SD1; L1 e L2 com o mesmo tamanho e posição que em A1 e A2. A8: com D1 na mesma posição dos segmentos anteriores; ausência de D2 e SD1; L1 e L2 acima do espiráculo. A9: com número reduzido de cerdas; presentes D1, como nos segmentos anteriores e L1 na mesma linha porém superior ao espiráculo. A10: com D1 quatro vezes maior que nos segmentos anteriores; D2 na base da projeção caudal; SD1 em posição oposta à D2 e SD2 pouco mais ventral (Fig. 19B). Nas pernas abdominais, os ganchos estão distribuídos na planta em mesossérie triordinal.

As primeiras mudas ocorreram após seis dias da eclosão. As larvas atingem $1 \mathrm{~cm}$ de comprimento.

\section{Larva de segundo estádio (Fig. 3B)}

Cabeça com três pares de escolos arredondados, o dorsal castanho e o dobro em tamanho que o lateral; os látero-ventrais, dois terços do tamanho do lateral, ambos castanho claro. Área frontal, desde o labro até o vértice, castanho, mandíbulas castanho mais escuro e genas bege. Textura irregular com várias cerdas claras sobre base escura, inclusive nos escolos.

Tegumento do corpo de coloração mais acentuada que na idade anterior. Permanecem as faixas longitudinais. Mancha oval sobre a linha média dorsal e metade basal do segundo segmento abdominal com as mesmas cores. Cerdas distribuídas pelo corpo sobre calaza mais clara que o tegumento. Espiráculos com peritrema preto.

Durante todo o dia permanecem isoladas, praticamente imóveis, em qualquer uma das faces da folha.

As primeiras mudas ocorreram oito dias após o início deste estádio. As larvas atingem o comprimento máximo de $1,8 \mathrm{~cm}$.

\section{Larva de terceiro estádio (Fig. 3C)}

Cabeça com mancha castanho escura, desde o par de escolos dorsais até próximo ao labro. Clípeo mais escuro que esta mancha. Escolos laterais com a base clara e o ápice escuro. Restante da cabeça castanho claro.

Tegumento do corpo e outras estruturas semelhantes ao estádio anterior, com exceção da faixa médio dorsal vermelha, substituída por estreita linha castanho escura. No quarto segmento abdominal um par de cerdas, laterais a esta linha, maiores e mais escuras que as do restante do corpo e com calaza totalmente preta.

As primeiras mudas ocorreram sete dias após o início deste estádio. As larvas atingem um comprimento máximo de $3 \mathrm{~cm}$. 

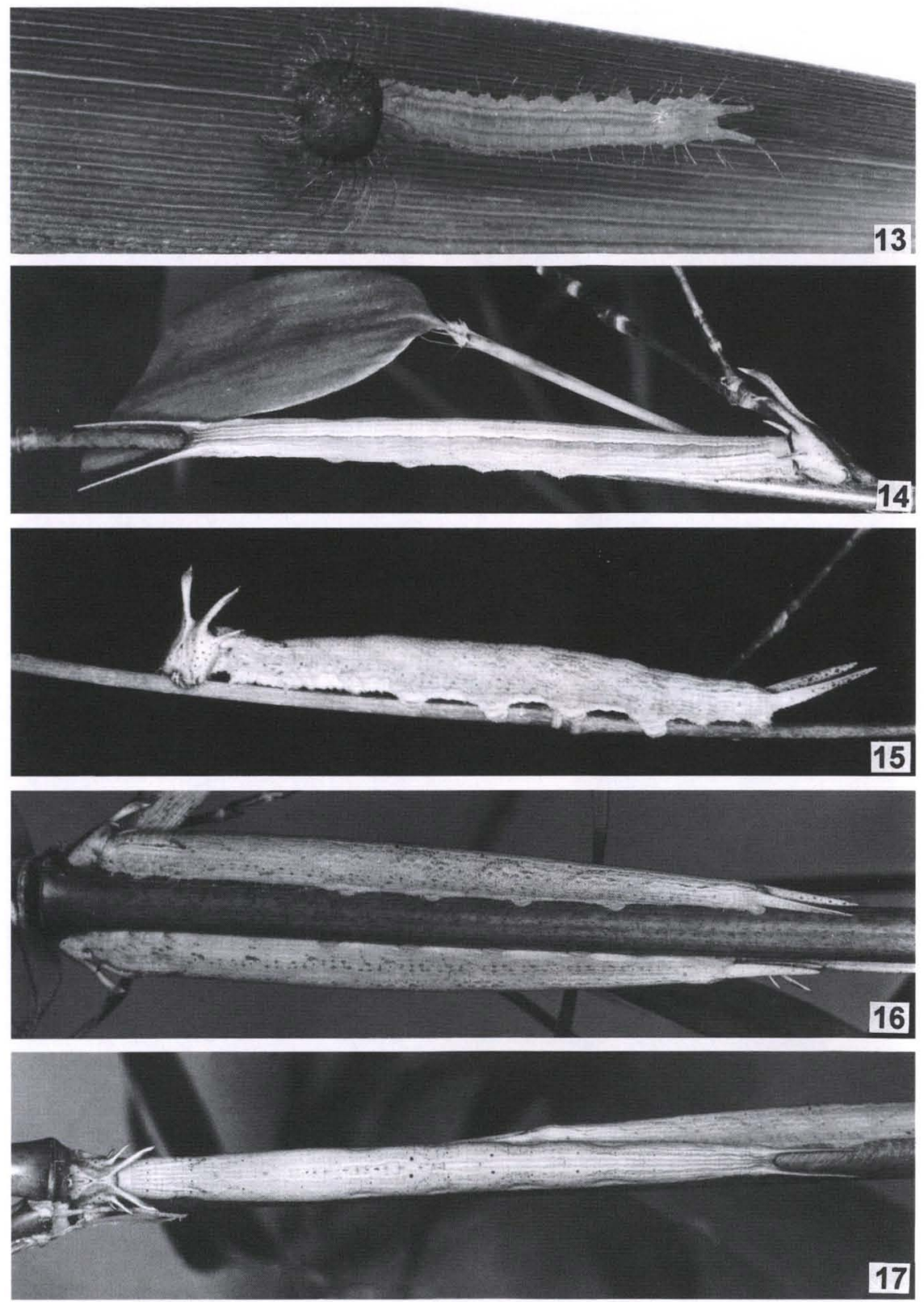

Figs 13-17. Narope cyllene. (13) Larva de primeiro estádio, vista dorsal; (14-17) larva de quinto estádio: (14-16) vista lateral; (17) vista dorsal. 

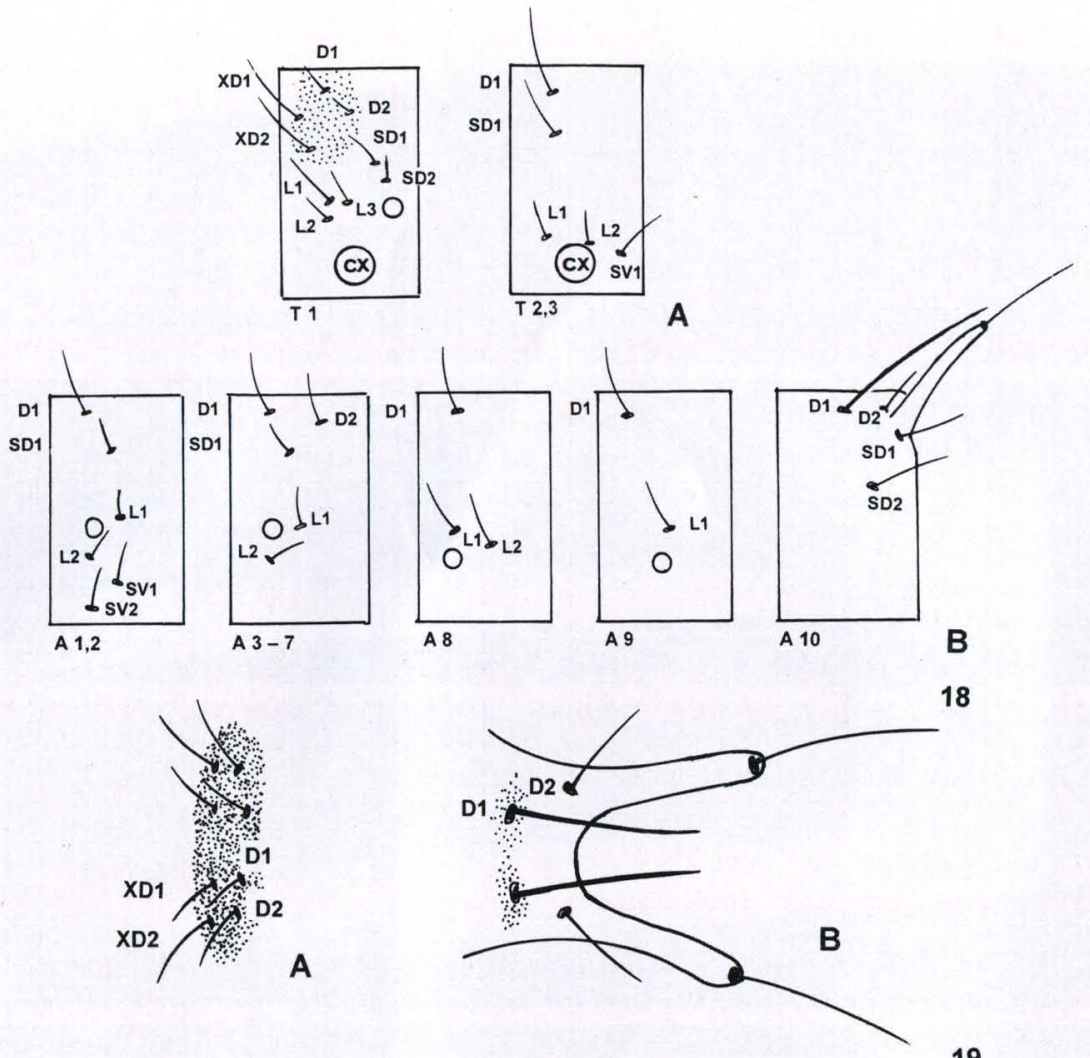

18

Figs 18-19. Narope cyllene. (18-19) Quetotaxia: (18A) tórax, (18B) abdome; (19A) placa protorácica, (19B) placa suranal.

\section{Larva de quarto estádio (Fig. 3D)}

Cabeça com clípeo claro, somente o espaço entre as suturas epicranial e adfrontal escura, como no estádio anterior. Escolos dorsais não tão escuros e somente na região frontal, lateral e posterior mais claros.

Tegumento do corpo percorrido por faixas longitudinais na cor palha, intercaladas em dois tons diferentes. As vermelhas no estádio anterior, são agora palha escuro, próximo ao bege. Linha média dorsal escura e inconspícua, ladeada por faixas de coloração palha em tons claros e escuros, formando área distinta. As cerdas dorsais e laterais do corpo são escuras sobre calaza clara. Do primeiro ao sétimo segmento, com um par de cerdas escuras maiores, na mesma posição daquelas do quarto segmento abdominal do estádio anterior, porém maiores. Nos mesmos segmentos, pouco mais distal e ventral outro par de cerdas com as mesmas características. Projeções da placa suranal, até então arredondadas, apresentam-se neste estádio achatadas lateralmente. 
Neste estádio e no próximo, provavelmente devido ao peso, as larvas abandonam durante o dia, as folhas, para ocupar os ramos de maior diâmetro ou o caule principal. Também à partir deste estádio a camuflagem é notável. As larvas mantêm a cabeça voltada para a parte inferior da planta, sempre próxima às ramificações e assim, as linhas bege do corpo confundem-se com a bainha seca do bambu e os escolos com os râmulos (Figs 14 e 17)

As primeiras mudas ocorreram doze dias após o início deste estádio. As larvas atingem o comprimento máximo de $4,1 \mathrm{~cm}$.

\section{Larva de quinto estádio (Figs 3E, 14-17)}

Cabeça de coloração palha. Mancha frontal pouco mais escura. Maioria das cerdas com calaza escura, nos escolos são claras. Os escolos dorsais perdem o aspecto arredondado dos estádios anteriores e passam a ser achatados lateralmente.

Tegumento do corpo com as mesmas faixas longitudinais em tons palha do estádio anterior. Meso e metatórax com um linha transversal de cerdas escuras sobre calaza de base clara e ápice escuro. No restante do corpo e projeções da placa suranal, calazas escuras dando ao corpo e as projeções da placa suranal um pontuado escuro sobre a cor palha do tegumento, muito similar aos pequenos pontos escuros sobre os ramos e caule principal do bambu (Figs 15 e 16).

As primeiras pupas surgiram vinte e três dias após o início deste estádio. As larvas atingem um comprimento máximo de $7,3 \mathrm{~cm}$.

Pupa (Fig. 20A-C)

Os locais preferidos pelas larvas ao darem início ao processo de pupação são o caule e os ramos secundários não muito finos. A quantidade de fios de seda ocupa invariavelmente um raio de $5 \mathrm{~cm}$ aproximadamente em todas as direções, até uma maior concentração no ponto onde realmente se prende.

A posição final da pupa é perpendicular ao ramo escolhido, onde a face dorsal dos segmentos A6 até o cremaster ficam paralelos e encostados no ramo.

De coloração geral âmbar, com matizes em vários tons de castanho escuro. Região cefálica mais escura dorsalmente, com duas projeções anteriores ao escapo. Antenas diferenciadas do restante do tegumento pela coloração esverdeada. Flagelômeros distintos por linha preta divisória.

Pronoto com a mesma coloração da cabeça, sem adornos ou detalhes. Mesotórax com projeção posterior dorso mediana mais escura, na face ventral com mais intensidade de tons escuros e com dois pares de projeções laterais aos lados das tecas alares. Mancha branco-leitosa entre o segundo par de projeções e o primeiro segmento abdominal. Perna mesotorácica com pequena projeção dirigida ântero-ventralmente, próxima ao primeiro terço da gálea. Metatórax sem adornos.

Segmentos abdominais mesclados com linhas mais escuras. Ventralmente faixa mediana mais clara.

Comprimento, do cremaster até o vértice de $1,5 \mathrm{~cm}$ e maior largura, na base das tecas alares, $0,7 \mathrm{~cm}$.

Os primeiros adultos (Figs 34 e 35) surgiram vinte dias após a fomação das primeiras pupas. 

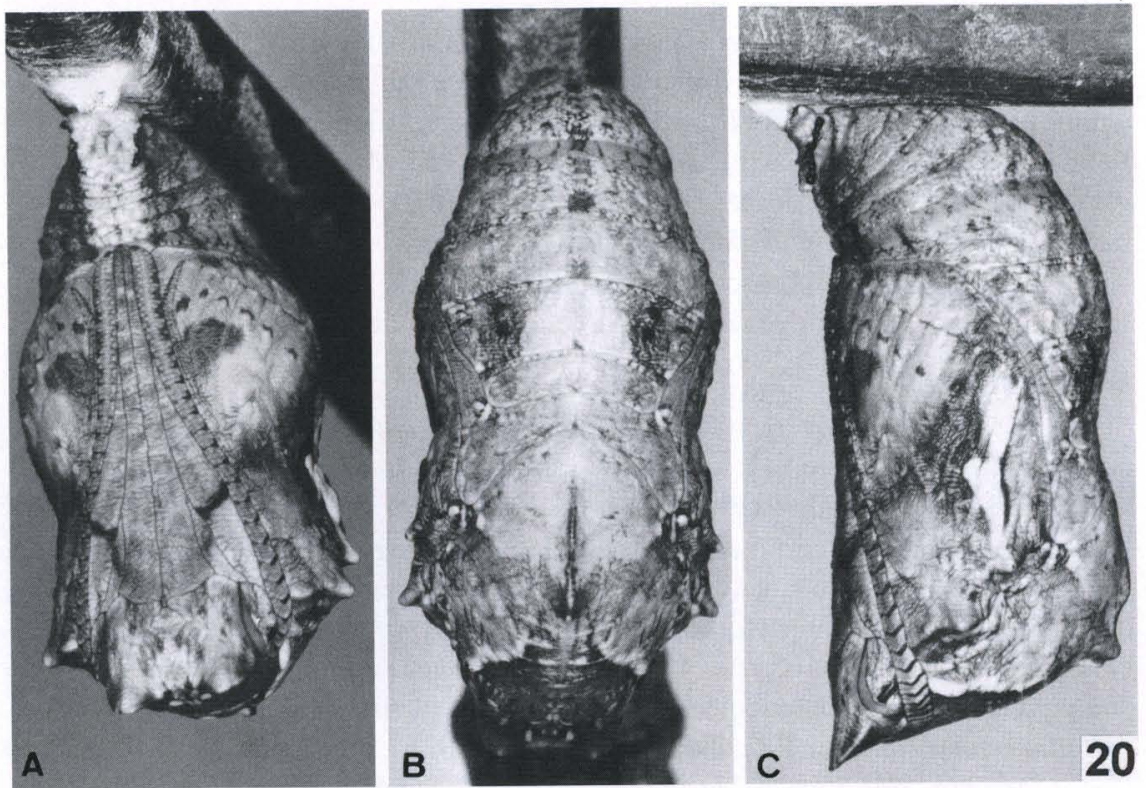

Fig. 20. Narope cyllene, pupa: (A) vista ventral, (B) vista dorsal, (C) vista lateral.

\section{Taxonomia}

Naropini (Stichel, 1925) Casagrande, 1996

Naropidi Stichel, 1925. Neue Beitr. syst. Insektenkunde 3: 58; tribo, incluindo Narope - Stichel, 1932. Lep. Cat. 51, p. 13; cit.

Naropinae Hayward, 1951. Acta zool. lill. 9: 219; cat.- Biezanko, 1960. Arq. Ent., sér. B, Pelotas, p. 7; distr. geogr., etol.- Hayward, 1973. Op. lill. 23: 241; cat.

Naropini Casagrande, 1996. Revta bras. Zool. 12: 684.- Mielke \& Casagrande, 1998. Revta bras. Zool. 14: 975.

Gênero tipo: Narope Doubleday, [1849]

\section{Caracterização morfológica}

Cabeça, tórax e abdome com a mesma coloração das asas. Olho glabro, palpo labial inerme e antena fusiforme.

Face dorsal das asas, com cores variando do castanho intenso (Figs 28-29), quase preto, até o amarelo (Figs 39-40); algumas espécies com manchas ou faixas amarelo ou ferrugíneo (Figs 44-45) e outras de coloração uniforme (Figs 100-101). Face ventral com matizes em castanho, amarelo, ferrugíneo, preto e violáceo. Em todas as espécies, a face ventral da asa anterior com uma linha, escura ou clara, entre o ápice e a metade da margem interna, dependendo da cor básica do restante da asa.

Androcônia (Figs 21-23) na face ventral da asa anterior sobre a metade de $2 \mathrm{~A}$, de aspecto oval e tamanho uniforme em todas as espécies da tribo. Exceto em 
Narope albopunctum todas são recobertas por pincel de escamas modificadas inseridas na margem interna (Figs 22-23). Na face dorsal da asa posterior, logo após a bifurcação Rs com $\mathrm{M}_{1}$, sobre Rs, androcônia em três tamanhos, pequena, média e grande (Fig. 24-26). Em Narope albopunctum o pincel está dentro da célula discal, próximo à base de $\mathrm{CuA}_{2}$.

Asa anterior com 11 veias que chegam às margens (Fig. 30F), quando com 12 , então $\mathrm{Sc}$ e $\mathrm{R}_{1}$, com anastomose próxima à base; $\mathrm{R}_{3}$ terminando no ápice da asa; bifurcação entre $\mathrm{R}_{3}$ e $\mathrm{R}_{4}$ na mesma direção ou posterior ao ângulo inferior da célula discal; $R_{4}$ reta ou levemente sinuosa terminando na margem externa; margem externa reta, com ápice recuado (Fig. 103 E), ou suavemente sinuosa e de ápice pouco projetado; androcônia na face ventral, acima de $2 \mathrm{~A}$, oval, coberta por escamas, exceto em Narope albopunctum. Asa posterior com veia umeral reta e de extremidade truncada; ângulo anal reto ou agudo.

Perna protorácica sem dimorfismo sexual quanto à divisão do tarso; tíbia inerme e tarso indiviso. Pernas meso e metatorácicas, em ambos os sexos, com esporões tibiais. Nos machos, fêmur mesotorácico menor que a tíbia mais o tarsômero proximal; fêmur metatorácico mais longo ou igual à tíbia; tíbia metatorácica com espinhos distribuídos desordenadamente e quase todos localizados na metade distal (Figs 30A-C e 103A-C).

Genitália masculina com subunco formado por placa estreita, alongada com ou sem extremidade trilobada. Valva em ponta, com projeções subapicais, ou truncada com denteado no bordo distal (Figs 31A, B e 104A, B)

Genitália feminina com lamela pós-vaginal oval ou retangular e com as porções laterias voltadas dorsal e distalmente. Lamela ante-vaginal reduzida e pouco esclerotinizada. Signos na bolsa ausentes (Figs 32 e 105). Papila anal mais longa que alta. 1982.

Gêneros incluídos. Narope Doubleday, [1849] e Aponarope Casagrande,

\section{Chave para os gêneros de Naropini}

1. Machos com a margem externa da asa anterior reta ou suavemente sinuosa e o ápice pouco projetado. Fêmures meso e metatorácicos sem espinhos (Figs 30 A e B). Nas fêmeas o fêmur protorácico é menor que a metade do tarso . Narope

- Machos com a margem externa da asa anterior reta e o ápice recuado. Fêmures meso e metatorácicos com espinhos (Figs 103 A e B). Nas fêmeas o fêmur protorácico é maior que a metade do tarso ............... Aponarope

\section{Narope Doubleday, [1849]}

Espécie tipo: Narope cyllastros Doubleday, [1849], por monotipia.

Narope Doubleday, [1849]. Gen. Diurn. Lep. 1, pl. 50, Fig. 4 -Narope cyllastros; tipo - única espécie incluida: Narope cyllastros.- Westwood, 1851, in Doubleday (Boiduval in litt.). Gen. Diurn. Lep. 2, p. 349; dg.- Lucas, 1851, in Chenu (ed.). Enc. d'Hist. Nat., Pap. Diurn., p. 171; cit.-Ménétriés, 1855. Enum. Corp. Anim. Mus. Petrop., Lep. 1, p. 39; cat.- Herrich-Schäffer, 1864. Corr.Blatt zool.- min. Ver. Regensburg 18: 99; cit.- Herrich-Schäffer, 1865. Corr.- Blatt zool. min. 
Ver. Regensburg 19: 65; cit.- Bates, 1864. Jour. Ent. 2: 176; cit.- Kirby, 1871. Syn. Cat. Diurn. Lep., p. 129; cat.-Scudder, 1875. Proc. Amer. Ac. Arts \& Sc. 10: 224; tipo do gênero: cyllastros.Wallace, 1876. Geogr. Distr. Anim. 2, p. 472; cit--Möschler, 1877. Verh. zool.- bot. Ges., Wien, 26: 322; cit.- F. Müller, 1877. Jena. Ztsch. Naturw. 11: 102; sist.- Kirby, 1878. Entomol. 11: 27.- Crüger, 1881. Berl. ent. Ztschr. 25: 110; cit.-Godman \& Salvin, 1881. Biol. Centr.-Amer., Lep. Rhop. 1, p. 139; sist.- Gerhard, 1883. Berl. ent. Ztschr. 27: 179; dg.- Glaser, 1887. Cat. etym. Lep. Col., p. 302; etimologia.- Staudinger, 1887, in Staudinger \& Schatz. Exot. Schmett. 1, p. 218; sist.- Röber, 1889, in Staudinger \& Schatz, Exot. Schmett. 2, p. 194; sist., biol.Richelmann, 1889. Tagebl. dtsch. Naturf. Versamml. 61: 69; dg.- Stichel, 1904, in Wytsman. Gen. Ins. 20, p. 4, 13, Fig. (venação), pl. 1, Fig. 15 (venação); sist.- Pagenstecher, 1909. Geogr. Verbreit. Schmett., p. 413; dg.-Stichel, 1909. Tierreich 25: 39; cat., sist., dg.-Fruhstorfer, 1912, in Seitz. Gross-Schmett. Erde 5, p. 327; sist.- Stichel, 1916. Neue Beitr. syst. Insektenk. 1: 7; sist.- Holdhaus, 1927, in Schröder. Handb. Ent. 2, p. 743.- Stichel, 1932. Lep. Cat. 51, p. 13; syn.: Naropina; cat.-Hayward, 1951. Acta zool. lill. 9: 219; syn.: Naropina; cat.-Hayward, 1954. Acta zool. lill. 14: 362; sist.- Hemming, 1967. Bull. Brit. Mus. (Nat. Hist.), Ent., Suppl. 9: 305; sist.- L. Miller, 1968. Mem. Amer. Ent. Soc. 24: 25, 28; sist.- Hayward, 1973. Op. Lill. 23:241; syn.: Naropina.- DeVries, 1987. Butt. Costa Rica, p. 256; dg.- Casagrande, 1996. Revta bras. Zool. 12: 687; sist.- D’Abrera, 1987. Butt. Neotrop. Reg. 3, p. 390; sist.

Pilopoecili Stichel, 1904, in Wytsman. Gen. Ins. 20, p. 14; seção de Narope, incluindo as coortes Cyllastroformes e Nesopiformes.- Stichel, 1909, Tierreich 25, p. 42; sist.- Stichel, 1931. Lep. Cat. 51: 14; cat.

Cyllastroformes Stichel, 1904, in Wytsman. Gen. Ins. 20, p. 14; coorte, incluindo Narope cyllastros, $N$. cyllarus, $N$. sarastro, $N$. anartes.- Stichel, 1909. Tierreich 25, p. 42; sist.- Stichel, 1932. Lep. Cat. 51: 14 ; cat.

Nesopiformes Stichel, 1904, in Wytsman. Gen. Ins. 20, p. 15; coorte, incluindo Narope nesope, $N$. cyllabarus, N. panniculus.- Stichel, 1909. Tierreich 25, p. 48; sist.- Stichel, 1916. Neue Beitr. syst. Insektenk. 1: 7; sist.- Stichel, 1932. Lep. Cat. 52: 16; cat.

Peracurii Stichel, 1904, in Wytsman. Gen. Ins. 20, p. 116; seção de Narope, incluindo Narope albopunctum.- Stichel, 1909. Tierreich 25, p. 49; sist.- Stichel, 1932. Lep. Cat. 51: 17; cat.

Naropina Röber, 1929. Int. ent. Ztschr. 23: 326; tipo -única espécie incluida: Naropina pusilla.-Hemming, 1967. Bull. Brit. Mus. (Nat. Hist.), Ent., Suppl. 9: 305; sist.

Naropa [sic]; Casagrande, 1991. Revta bras. Zool. 7: 135; Naropa cyllastros.

Caracterização morfológica do adulto (Figs 21-97). Asa anterior com margem externa levemente sinuada ou reta, ápice na mesma direção ou levemente projetado. Com 11 veias que atingem as margens costal e externa. Sc e $\mathrm{R}_{1}$ anastomosam logo após a dcs. $\mathrm{R}_{3}$ termina no ápice da asa.

$\mathrm{Na}$ asa posterior, o contorno pode ser arredondado ou projetado com acompanhamento de veia. Face dorsal, com área de aspecto brilhoso e sem escamas da célula umeral até pouco além da base da bifurcação Rs com M1. No centro desta área, sobre Rs, escamas diferenciadas formam androcônia de forma arredonda ou oval, em três tamanhos distintos, pequena, média e grande, nas cores branca, creme ou ferrugínea (Figs 24-26).

$\mathrm{Na}$ face ventral da asa anterior, sobre a metade proximal de $2 \mathrm{~A}$, androcônia com escamas creme ou bege, de tamanho médio, quando comparada à aquela da face dorsal da asa posterior. Sobre essas escamas um pincel de pêlos, distribuídos

Figs 21-23. Asa anterior. (21) Narope cyllabarus, androcônia da face ventral da asa em vista dorsal; (22) Narope cyllabarus, pincel de pêlos, sobre androcônia da face ventral da asa em vista ventral; (23) Narope testacea, pincel de pêlos, semi aberto sobre androcônia da face ventral da asa em vista ventral. 

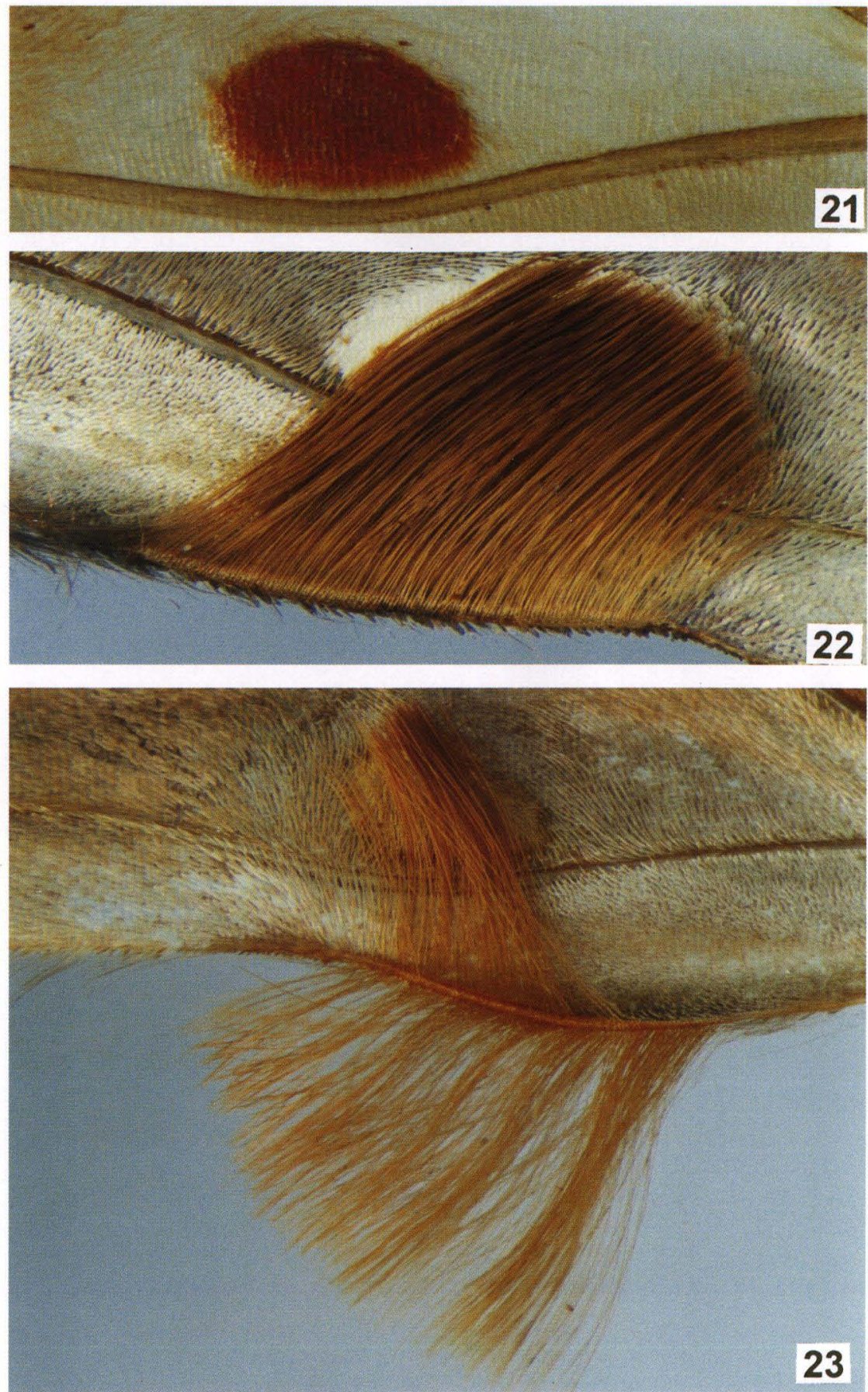

Revta bras. Zool. 19 (2): 467 - 569, 2002 

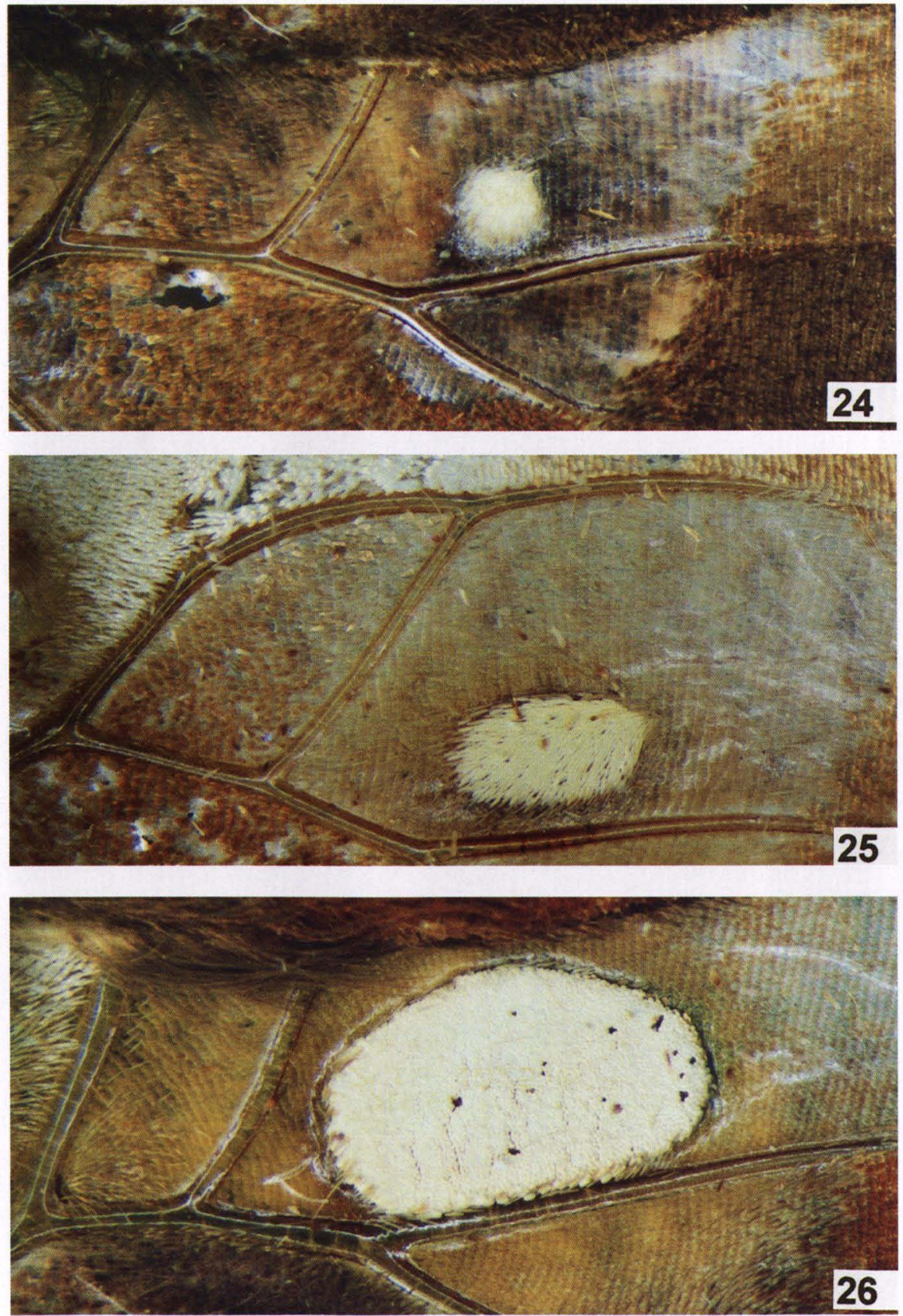

Figs 24-26. Asa posterior, face dorsal, androcônia: tamanhos. (24) Narope guilhermei, pequena; (25) Narope anartes, média; (26) Narope cyllabaus, grande.

Revta bras. Zool. 19 (2): $467-569,2002$ 

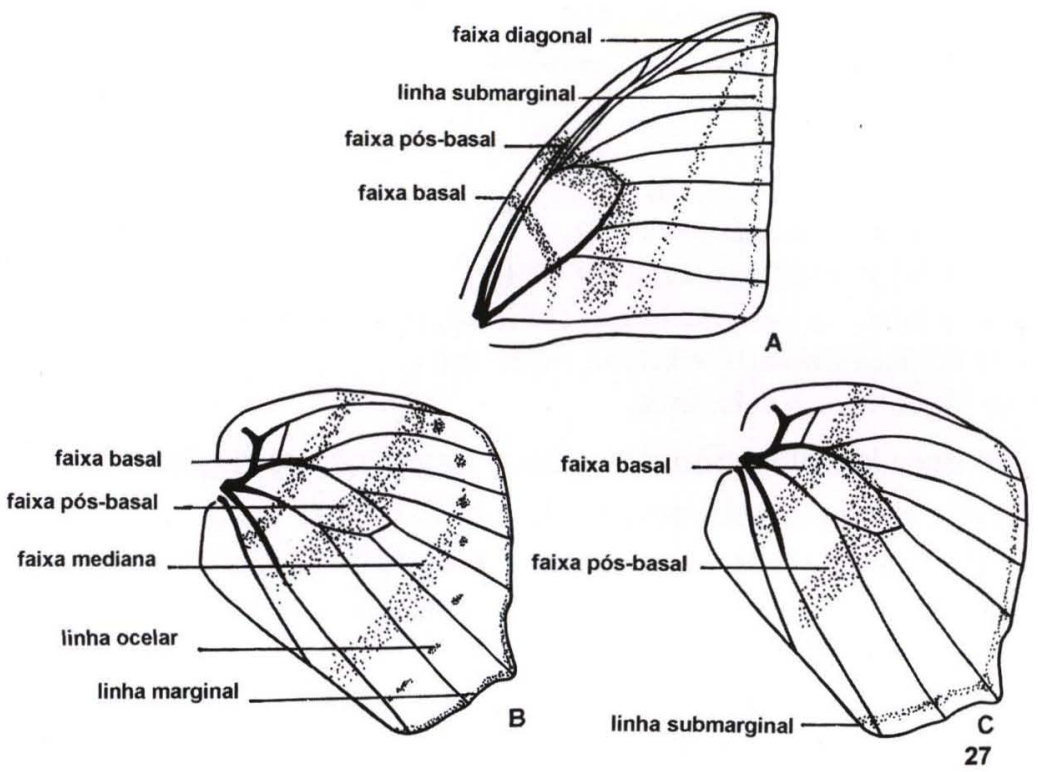

Fig. 27. Narope, distribuição de manchas, faixas e linhas: (A) asa anterior, (B e C) asa posterior.

de forma linear sobre uma dobra formada pela margem interna da asa. A extensão da faixa de pêlos corresponde ao tamanho da mancha (Figs 21-23). Em Narope albopunctum pincel de pêlos, dentro da célula discal, na base de $\mathrm{CuA}_{1}$ (Fig. 95).

Nas fêmeas, o fêmur da perna protorácica menor que o tarso (Fig. 30 D).

Nos machos, fêmures das pernas meso e metatorácicas inermes (Fig. 30A-B).

Genitália masculina com valva em ponta ou pouco arredondada distalmente. Juxta presente e edeago inerme e liso com vesica se projetando da face ventral (Fig. 31).

Genitália feminina com lamela pós-vaginal desenvolvida e fortemente esclerotinizada, lamela ante-vaginal reduzida e pouco esclerotinizada. Bolsa copuladora alongada ou arredondada (Fig. 32).

\section{Espécies e subespécies incluídas}

Narope albopunctum Stichel, 1904

Narope anartes Hewitson, 1874

Narope cauca Casagrande, sp. n.

Narope cyllabarus Westwood, 1851

Narope cyllarus Westwood, 1851

Narope cyllastros Doubleday, [1849]

Narope cyllene C. Felder \& R. Felder, 1859

Narope denticulatus Talbot, 1928, stat. rev. 
Narope guilhermei Casagrande, 1989

Narope marmorata Schaus, 1902, stat. rev.

Narope minor Casagrande, sp. $\mathbf{n}$.

Narope nesope Hewitson, 1869

Narope obidos Casagrande, sp. n.

Narope panniculus Stichel, 1904

Narope syllabus syllabus Staudinger, 1887

Narope syllabus stygius Staudinger, 1887, ssp. rev., comb. n.

Narope testacea Godman \& Salvin, 1878, stat. n.

Narope ybyra Casagrande, sp. $\mathbf{n}$.

\section{Chave para identificação de machos das espécies de Narope}

1. Margem externa da asa posterior, reta entre Rs e CuA1 ............ 2

- Margem externa da asa posterior, convexa entre Rs e $\mathrm{CuA}_{2} \ldots \ldots \ldots \ldots .10$

2. Face dorsal das asas anterior e posterior com amarelo, laranja, castanho ferrugíneo ou castanho escuro . . . . . . . . . . . . . . . . . . . . . . . . 3

- Face dorsal da asa anterior amarelo ferrugíneo e da asa posterior castanho, com faixa marginal amarelo ferrugíneo ................. guilhermei

3. Face dorsal das asas anterior e posterior castanho escuro . . . . . . . . 4

- Face dorsal das asas anterior e posterior laranja ferrugíneo ou castanho ferrugíneo

4. Margem externa de ambas as asas com franjas creme ............. 5

- Margem externa de ambas as asa com franjas concolores ..............6 6

5. Face ventral da asa posterior com linha submarginal acompanhando a projeção em $\mathrm{CuA}_{1} \ldots \ldots \ldots \ldots \ldots \ldots \ldots \ldots \ldots \ldots \ldots \ldots \ldots \ldots$ denticulatus

-Face ventral da asa posterior com linha submarginal reta e não projetada em $\mathrm{CuA}_{1}$

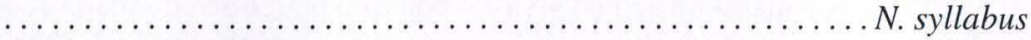

6. Androcônia das asas anterior e posterior de igual tamanho ......... cyllastros - Androcônia da asa posterior um quinto do tamanho daquela da asa anterior .... N. cyllene

7. Face dorsal das asas anterior e posterior, com linha marginal ou submarginal de escamas escuras . . . . . . . . . . . . . . . . . . . 8

- Face dorsal das asas anterior e posterior, com linha marginal ou submarginal de escamas escuras ausente em uma ou ambas as asa . ............9

8. Linha submarginal da face dorsal presente em ambas as asas ....... cyllarus - Linha marginal da face dorsal, presente em ambas as asas ........ N testacea 9. Linha submarginal presente na face dorsal da asa posterior .......... minor - Linha submarginal ausente na face dorsal das asa posterior ....... . marmorata 10. Ápice da asa anterior com a mesma cor do restante da asa .......... 11 - Ápice da asa anterior escuro ......................... 13 
11. Face dorsal da asa anterior com mancha arredondada escura abaixo da célula

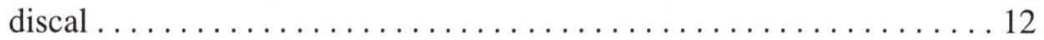

- Face dorsal da asa anterior sem essa mancha ................ 14

12. Face dorsal da asa anterior castanho escuro ................ panniculus

- Face dorsal da asa anterior castanho escuro com ferrugíneo .......... Nesope

13. Face dorsal das asas anterior e posterior laranja ferrugíneo .......... ybyra

- Face dorsal das asas anterior e posterior castanho ferrugíneo . . . . . . . . 15

14. Face dorsal das asas anteriror e posterior castanho escuro, sem ferrugíneo, com mancha de escamas brancas entre $\mathrm{R}_{5}$ e $\mathrm{M}_{1} \ldots \ldots \ldots \ldots . .$. albopunctum

- Face dorsal das asas anterior e posterior castanho claro ferrugíneo ou castanho escuro ferrugíneo .......................... 16

15. Asa posterior com margem externa crenulada $\ldots \ldots \ldots \ldots \ldots \ldots$. anartes

- Asa posterior com a margem externa arredondada ................ cauca

16. Face dorsal das asa anterior e posterior laranja ferrugíneo intenso. Androcônia da asa posterior, oval, quase tão longa quanto alta. Face ventral de ambas as asas com amarelo intenso e faixas e manchas castanho ........ cyllabarus

- Face dorsal das asas anterior e posterior castanho ferrugíneo, mais intenso nas asas anteriores. Androcônia das asas posteriores mais longa que alta. Face ventral em bege, com faixas e manchas castanho ............ obidos

\section{Chave para identificação de fêmeas das espécies de Narope}

A chave trata das fêmeas disponíveis nas coleções estudadas: $N$. anartes, $N$. cyllabarus, $N$. cyllarus, $N$. cyllastros, $N$. cyllene, $N$. guilhermei, $N$. panniculus, $N$. cauca sp. n., $N$. syllabus stygius, $N$. testacea, $N$. obidos $\mathbf{s p .}$ n. e $N$. minor $\mathbf{s p .}$.

1. Face dorsal da asa anterior com mancha subapical em amarelo ou laranja

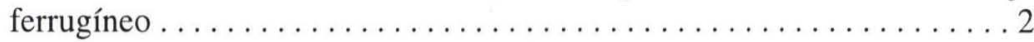

- Face dorsal da asa anterior sem manchas, se com escamas ferrugíneas sobre castanho, as escamas ferrugíneas estão esparsas sobre o ramo da veia mediana e na linha marginal de ambas as asas . .............. 3

2. Face dorsal da asa anterior com mancha laranja ou amarelo ferrugíneo em meia

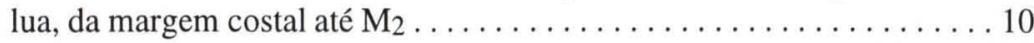

- Face dorsal da asa anterior com mancha amarelo ferrugíneo em meia lua, da margem costal até $2 \mathrm{~A} \ldots \ldots \ldots \ldots \ldots \ldots \ldots \ldots \ldots \ldots \ldots \ldots \ldots \ldots \ldots$ gulhermei

3. Face dorsal das asas anterior e posterior laranja ferrugíneo, com faixa submarginal de escamas escuras . . . . . . . . . . ................ cyllarus

- Face dorsal das asas anterior e posterior castanho sem ferrugíneo, ou quando presente de forma esparsa . . . . . . . . . . . . . . . . . 4

4. Asa posterior com margem externa projetada de forma acentuada em $\mathrm{M}_{3}$, ou em

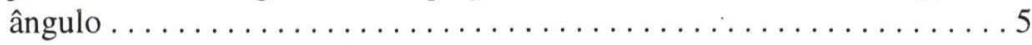

- Asa posterior com margem externa arredondada .............. panniculus 
5. Asa posterior com margem externa crenulada, linha marginal em ambas as asas pouco mais clara que o restante das asas . . . . . . . . . . . . . 6

- Asa posterior com margem externa reta, exceto por projeção em $M_{3}$, linha marginal mais clara e com escama ferrugíneas em ambas as asas . . . . . 9

6. Face dorsal das asas anterior e posterior castanho claro. América Central . . . 7

- Face dorsal das asas anterior e posterior castanho escuro. América do Sul . . . 8

7. Face ventral da asa posterior com aspecto marmorizado e faixa submarginal branca com reflexos prateados ....................... testacea - Face ventral da asa posterior sem esses caracteres ............. N. minor

8. Face ventral da asa anterior com pequena mancha ocelar escura com escamas claras no centro, no terço distal da asa, entre $\mathrm{M}_{1}$ e $\mathrm{M}_{2} \ldots$. . syllabus stygius

- Face ventral da asa anterior sem esta mancha ................ 11

9. Face ventral das asas anterior e posterior com linha marginal castanho claro seguida de linha submarginal castanho escuro .............. cyllabarus

- Face ventral das asas anterior e posterior sem linha marginal ou submarginal evidentes ................................. obidos

10. Face dorsal da asa anterior com mancha amarelo ferrugíneo, em meia lua, que se projeta em direção ao ápice da asa, desde a base de $\mathrm{R}_{4+5} \operatorname{com} \mathrm{M}_{1}$, no ápice superior da célula discal. Asa posterior com margem externa arredondada . N. cauca

- Face dorsal da asa anterior com mancha amarela não se projetando como acima. Asa posterior com margem externa crenulada, pouco mais projetada em $\mathrm{M}_{3}$

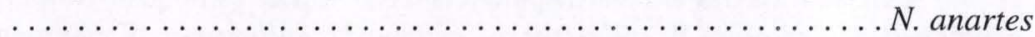

11. Asa posterior com margem externa acentuadamente crenulada, voa em altitudes acima de 300 m. Lamela pós-vaginal com depressão mediana . . . N. cyllene - Asa posterior com margem externa de suave crenulado, voa ao nível do mar até 300 m. Lamela pós-vaginal sem depressão mediana distal ..... N.cyllastros

\section{Narope cyllastros Doubleday, [1849]}

\section{Figs 28-35}

Narope cyllastros Doubleday, [1849], in Doubleday (Boisduval in litt.). Gen. Diurn. Lep. 1, pl. 50, Fig. 4 (dorsal).- Westwood, 1851, in Doubleday. Gen. Diurn. Lep. 2, p. 349; Pará, Brasil; BM(NH).Lucas, 1851, in Chenu (ed.). Enc. d'Hist. Nat., Pap. Diurn., p. 172, fig. 283 (d); dg.- Ménétriés, 1855. Enum. Corp. Anim. Mus. Petrop., Lep. 1, p. 39; cat., dg.- Herrich-Schäffer, 1865. Corr.Blatt. zool.- min. Ver. Regensburg 19: 65; cit-- Kirby, 1871. Syn. Cat. Diurn. Lep., p. 129; cat.-Scudder, 1875. Proc. Amer. Ac. Arts \& Sc. 10: 224; tipo do gênero: N. cyllastros.- Möschler, 1877. Verh. zool.- bot. Ges., Wien, 26: 322; cit.- W. Müller, 1886. Zool. Jahrb., Syst. 1, p. 601; planta hosp., dg.- Staudinger, 1886, in Staudinger \& Schatz. Exot. Schmett. 1, pl. 76 (macho d, v).- Staudinger, 1887, in Staudinger \& Schatz. Exot. Schmett. 1, p. 218; sist., dg.- Schatz, 1888, in Staudinger \& Schatz. Exot. Schmett. 2, pl. 32 (palpo, venação).- Röber, 1888, in Staudinger \& Schatz. Exot. Schmett. 2, p. 194; sist.- Stichel, 1909. Tierreich 25, p. 42; cat., sist., dg.Fruhstorfer, 1912, in Seitz. Gross-Schmett. Erde 5, p. 328, pl. 62d (macho d, fêmea v); syn.: cyllene; sist., planta hosp., biol., dg.- Stichel, 1916. Neue Beitr. syst. Insektenkunde 1: 7; sist.Seitz, 1924, in Seitz, Gros-Schmett. Erde 5, p. 1134 (errata).- Zikán, 1928. Ent. Rdsch. 45: 11; 
dg.- Köhler, 1928. Publ. Breyer, Buenos Aires, p. 2; cit., dg. - Stichel, 1932. Lep. Cat. 51, p. 14; cat. syn.: cyllene, cyllastros f. stygius.- Bates, 1932. Bull. Brooklyn Ent. Soc. 27: 157, 158; planta hosp.- Hemming, 1941. Jour. Soc. Bibl. Nat. Hist. 1(2): 451; sist., dg.- Hayward, 1951. Acta zool. lill. 9: 219; syn.: cyllene; cyllastrus; cat., dg.- L. Miller, 1968. Mem. Amer. Ent. Soc. 24: 24, Fig. 19 (venação); sist.- Hayward, 1973. Op. lill. 23: 241; syn.: cyllene, cyllastrus; cat.; dg.Smart, 1976. Enc. Butt. World, p. 240, fig. 7 (d); dg.- Casagrande, 1991. Revta bras. Zool. 7 : 129, 137, Fig. 11 (venação); sist., dg.- Casagrande, 1996. Revta bras. Zool. 12: 686, figs 29, 30 (venação), 33 (gen. masc.), 37 (gen. fem.); sist.- Lewis, 1973. Butt. World, p. 29, Fig. 11 (d, v), p. 222; dg.- Lewis, 1975. Marip. Mundo, p. 29, fig. 11 (d, v), p. 222; dg.- K. Brown, 1992, in Morellato. Hist. nat. Japi, p. 150, 151, figs 10 (macho d), 11 (fêmea v); dg.- Penz, Aiello \& Srygley, 2000. Jour. Lep. Soc. 53(4): 149; planta hosp.

Narope cyllastrus [sic]; Bönninghausen, 1896. Verhandl. Ver. naturw. Unterh. Humburg 9: 39; dg.Köhler, 1923. Ztschr. wiss. Insektenb. 18, Sonderb., p. 21; dg.- Kivirikko, 1936. Ann. Ent. Fenn. 2(2): 54; dg.- J. Zikán \& W. Zikán, 1968. Pesq. agropec. bras. 3: 50; planta hosp. dg.

Narope cyllastros cyllastros; Stichel, 1904. Ins. Börse 21: 197; syn.: cyllene, stygius; sist., dg.- Stichel, 1904, in Wytsman. Gen. Ins. 20, p. 14; syn.: cyllene, stygius; cat., dg.- Stichel, 1909. Tierreich 25, p. 43; syn.: cyllene, stygius; cat., sist., dg.- Stichel, 1932. Lep. Cat. 51: 14; syn.: cyllene, cyllastros f. stygius; cat., dg.- Podtiaguin, 1944. Revta Soc. Cient. Paraguay, VI (4):24; dg.Silva et al., 1968. Quarto Cat. Ins. viv. Plantas Brasil 2(1), p. 328; planta hosp., dg.- D'Abrera, 1987. Butt. Neotrop. Reg. 3, p. 390, figs (macho d, fêmea v); sist., dg.- Mielke \& Casagrande, 1998. Revta bras. Zool. 14: 975; dg.- Penz, Aiello \& Srygley, 2000. Jour. Lep. Soc. 53(4): 149; planta hosp.

Naropa [sic] cyllastros; Casagrande, 1991. Revta bras. Zool. 7: 135.

Narope cylastros [sic]; Casagrande, 1996. Revta bras. Zool. 12: 686, fig. 36 (gen. fem.).

Histórico. A primeira citação para a espécie DOUBLEDAY (1849) é uma figura publicada no primeiro volume do "The Genera of Diurnal Lepidoptera". No segundo volume do mesmo trabalho, WESTWOOD (1851) cita a procedência como sendo do Pará, Brasil, certamente um erro, pois a distribuição da espécie está restrita ao sudeste e sul do Brasil.

Material tipo. Narope cyllastros baseia-se em número não definido de exemplares. No "The Natural History Museum" Londres, Inglaterra, foi encontrado um exemplar macho, aqui designado, como LECTÓTIPO, com o objetivo de garantir a adequada identificação da espécie, com as seguintes etiquetas: /Type/ Narope cyllastros, D. \& H.G.D.L pl 50 f 4/ B.M. TYPE N ${ }^{\circ}$ Rh 6114 Narope cyllastros macho D.W. \& H./ LECTOTYPE/ Narope cyllastros Doubleday, [1849], Lectotype, M.M. Casagrande det. 2002/.

Diagnose. Face dorsal das asas anterior e posterior castanho escuro sem manchas ou faixas de outra cor. Androcônia das asas anterior e posterior de igual tamanho. Faixa basal da face ventral da asa posterior reduzida, com início dentro da célula discal e não na margem costal. Genitália masculina com valva em ponta e duas carenas de espinhos na face interna da metade distal.

Descrição. Macho (Figs 28, 30A-C, E, 31). Asa anterior: comprimento da margem costal - 28 a $32 \mathrm{~mm}$; margem externa - 21 a $24 \mathrm{~mm}$; largura da asa - 18 a $21 \mathrm{~mm}$. Asa posterior: comprimento da margem costal - 19 a $21 \mathrm{~mm}$; margem externa - 21 a $23 \mathrm{~mm}$; maior comprimento da asa -23 a $27 \mathrm{~mm}$.

Cabeça e apêndices, tórax e abdome castanho.

Face dorsal das asas anterior e posterior castanho a castanho escuro, mais escuro e de aspecto esfumaçado na margem externa e diluindo para a base. Asa posterior com margem externa reta desde Rs até $\mathrm{CuA}_{1}$ e androcônia oval de tamanho médio, creme, pouco além da bifurcação Rs-M1, sobre Rs. 

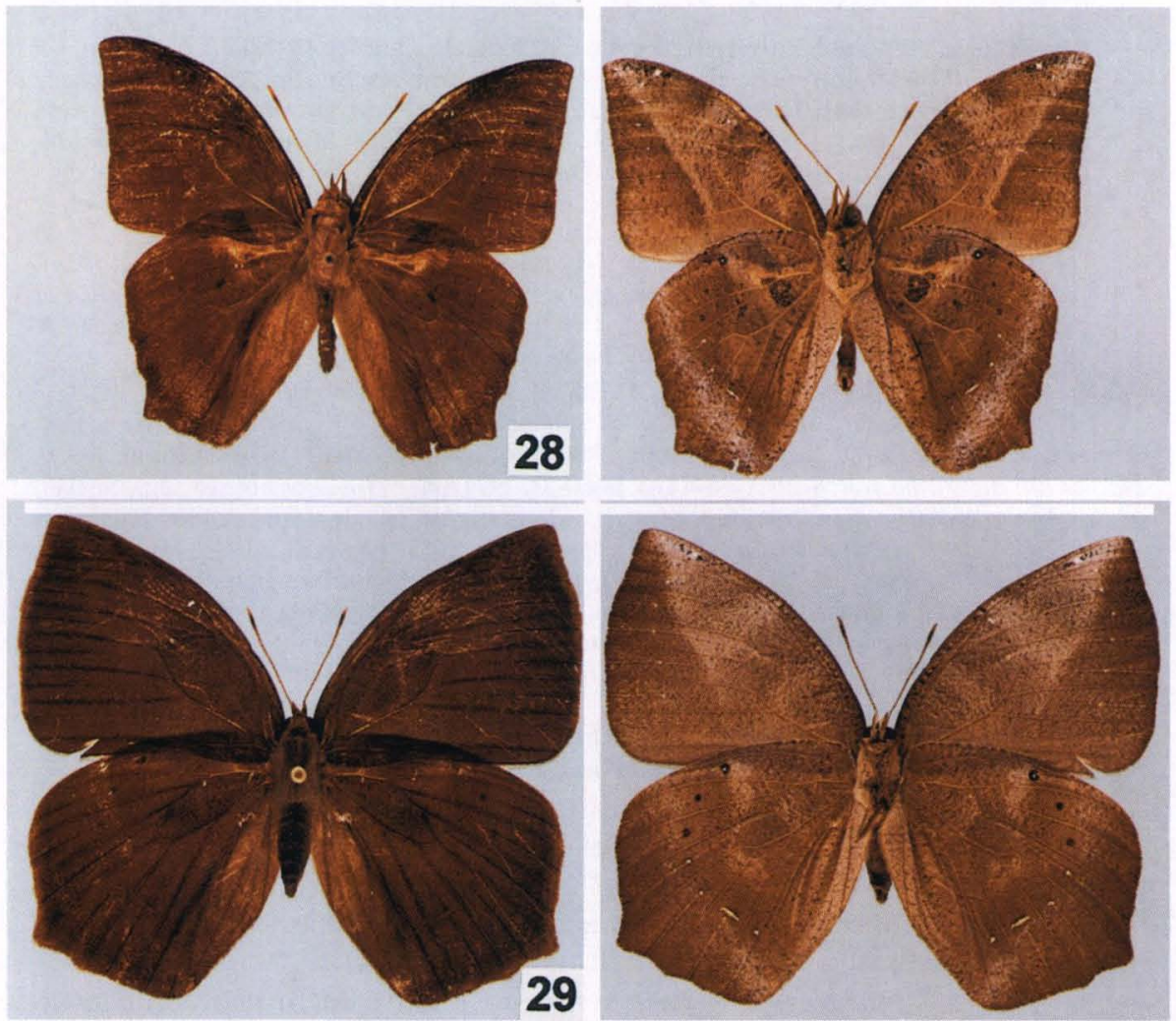

Figs 28-29. Narope cyllastros. (28) Macho, vistas dorsal e ventral; (29) fêmea, vistas dorsal e ventral.

Face ventral da asa anterior, dividida em duas áreas por uma linha diagonal desde o ápice até aproximadamente o meio de $2 \mathrm{~A}$, sendo a parte distal castanho amarelado e a proximal castanho claro. Em ambos os lados pequenos aglomerados de escamas mais escuras se distribuem de maneira uniforme. Pequenos pontos formados por escamas brancas entre $\mathrm{R}_{3} \mathrm{e} \mathrm{R}_{4}$ pouco antes do ápice. Ainda sobre as discocelulares e na parte central da célula discal, duas manchas mais escuras, faixas basal e pós-basal pouco pronunciadas. Sobre a metade proximal de $2 \mathrm{~A}$, androcônia de forma oval, com escamas creme e de igual tamanho àquelas da face dorsal das asas posteriores.

Face ventral da asa posterior, um conjunto de escamas pretas definem a faixa basal, no meio da célula discal. Sobre as discocelulares, linha diagonal, parece dar continuidade à aquela das asas anteriores, desde a margem costal até a margem interna. Da mesma forma que na asa anterior, a metade proximal é mais clara e a distal mais escura. Uma série de pontos submarginais acompanham a forma convexa da margem externa, os dois primeiros escuros e os quatro seguintes creme, o penúltimo destes, de forma alongada como um traço. Destes pontos até pouco antes da margem externa uma faixa de cor violácea. 


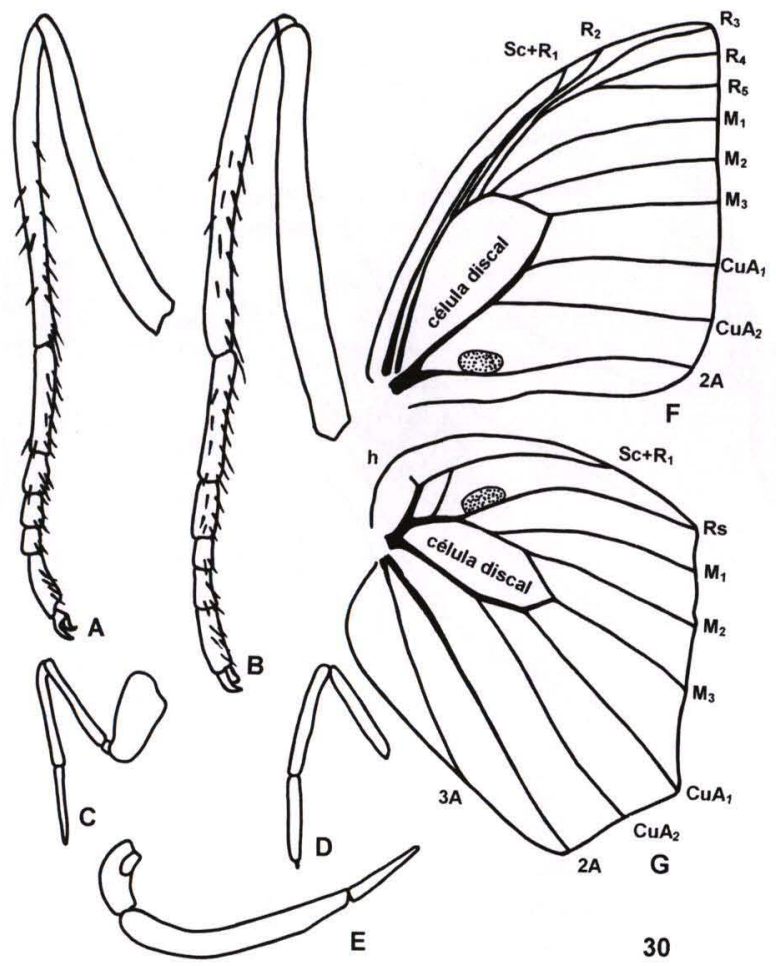

Fig. 30. Narope cyllastros: (A) macho, perna metatorácica, (B) macho, perna mesotorácica, (C) macho, perna protorácica, (D) fêmea, perna protorácica, (E) macho, palpo labial, (F) macho, asa anterior, (G) macho, asa posterior.

Genitália (Fig. 31A-E). Unco com a metade basal alargada, afilando distalmente. Subunco projetado dorsalmente, pouco maior que a metade do unco e com duas pontas no ápice. Valva em ponta, projetada além do término do unco, margem superior serrilhada; da metade interna até o ápice uma depressão aloja uma série de espinhos esclerotinizados com duas pronunciadas carenas. Juxta, em vista ventral, cordiforme.

Fêmea (Figs 29, 30D, 32). Asa anterior: comprimento da margem costal 31 a $36 \mathrm{~mm}$; margem externa - 20 a $26 \mathrm{~mm}$; largura da asa - 21 a $24 \mathrm{~mm}$. Asa posterior; comprimento da margem costal - 22 a $27 \mathrm{~mm}$; margem externa - 23 a 28 $\mathrm{mm}$; maior comprimento da asa - 28 a $33 \mathrm{~mm}$.

Face dorsal das asas anterior e posterior castanho claro e como nos machos, sem manchas ou faixas.

Face ventral mais clara. Pequenos conjuntos de escamas escuras distribuídas por toda a superfície das asas. Como nos machos, linha diagonal desde o ápice da asa anterior até a metade de $2 \mathrm{~A}$, e na asa posterior da metade da margem costal até à metade da margem interna. A área proximal é mais clara que a distal. $\mathrm{Na}$ asa posteriores margem externa crenulada e projetada em ponta em $\mathrm{M}_{3}$. 


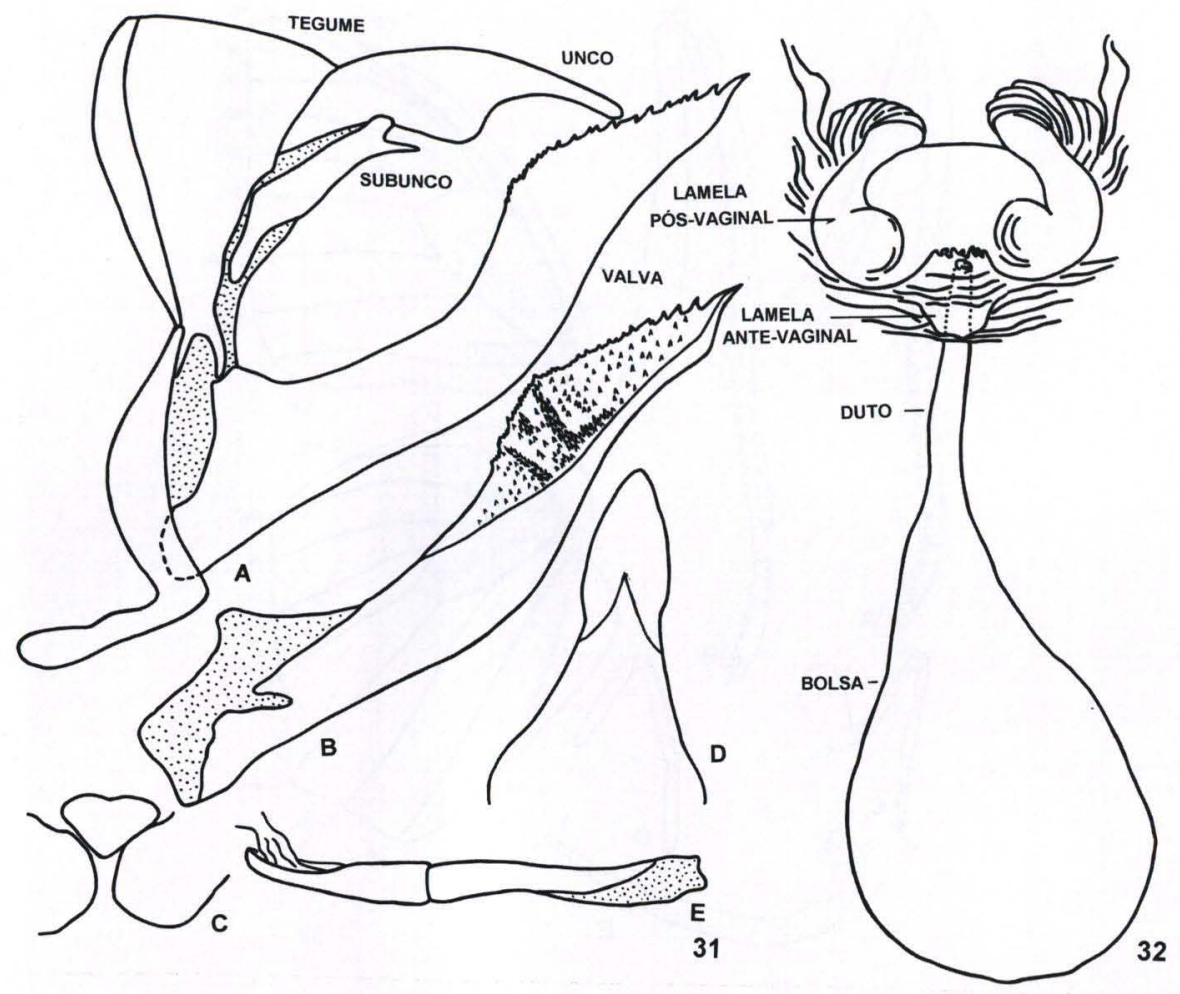

Figs 31-32. Narope cyllastros. (31) Genitália masculina: (A) vista lateral, (B) valva, vista lateral interna, (C) juxta, vista ventral, (D) tegume/unco, vista dorsal, (E) edeago, vista lateral; (32) genitália feminina, vista ventral.

Genitália (Fig. 32). Lamela pós-vaginal em forma de placa retangular com extremidades arredondadas, esclerotinizada e com superfície anterior voltada ventralmente. Lamela ante-vaginal pequena em relação à pós-vaginal e pouco esclerotinizada. Corpo da bolsa maior que o duto; bolsa alongada.

Discussão. Aproxima-se de $N$. cyllene pelo aspecto cromático e forma das asas; diferencia-se pela androcônia na face dorsal da asa posterior de tamanho médio, similar à aquela da face ventral da asa anterior, enquanto que em $N$. cyllene (Fig. 34) são menores. De $N$. guilhermei (Figs 44-45) diferencia-se pela ausência de coloração ferrugínea nas asas e também pelo tamanho maior da androcônia da face dorsal da asa posterior.

Distribuição espacial. (Fig. 33). BRASIL, Minas Gerais: Caxambú; Rio de Janeiro: Rio de Janeiro, Duque de Caxias, Xerém, Imbariê; São Paulo: Rio Claro, Paraná: Rolândia, Porecatu; Santa Catarina: Joinville, Seara; Rio Grande do Sul: Guarany, São Leopoldo. PARAguAI. ARgentina, Missiones.

Distribuição temporal. Voa durante todo o ano nos lugares mais quentes, enquanto que no sul do país, de outubro até março ou abril, no final do verão. 


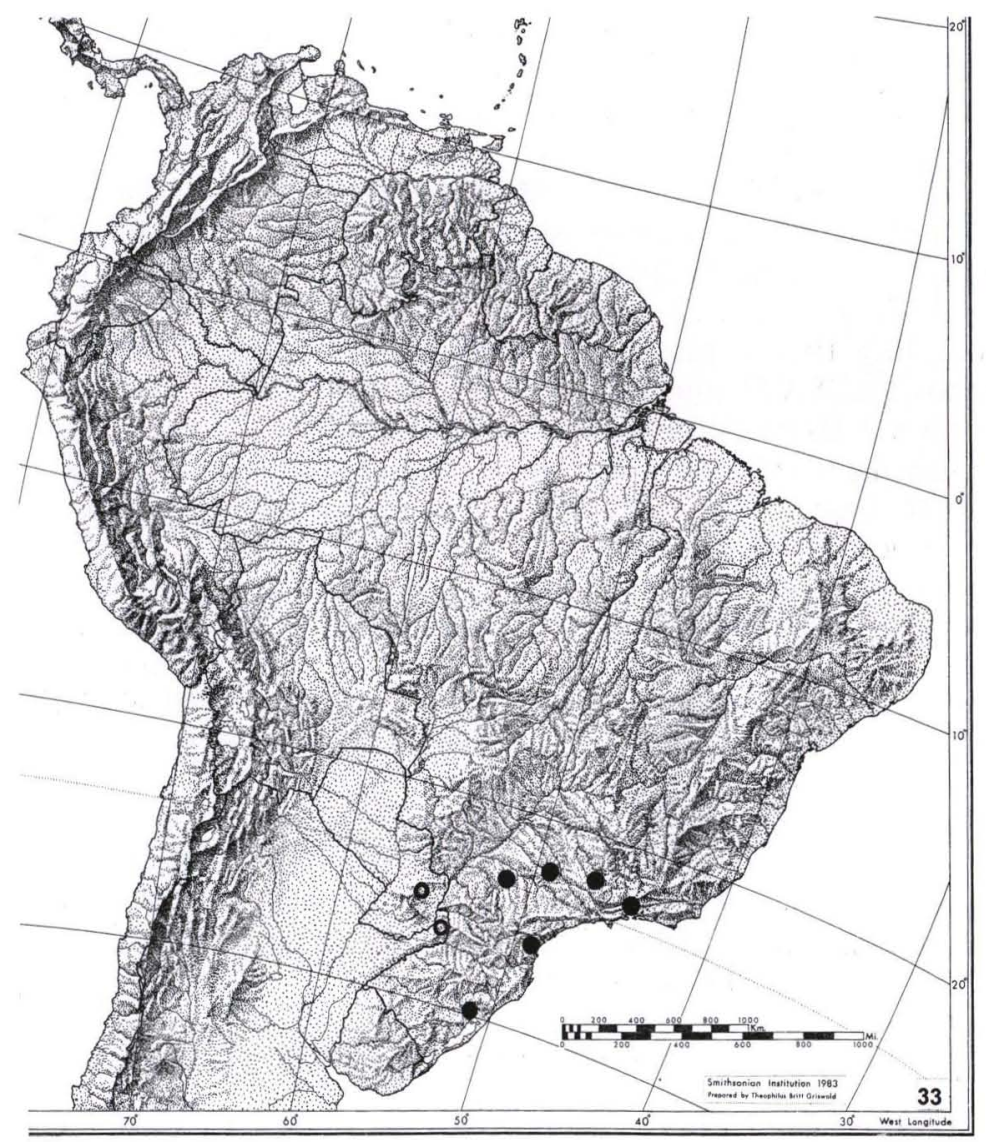

Fig. 33. Narope cyllastros, distribuição espacial.

Etologia. Voa em lugares baixos desde o nível do mar sem ultrapassar $300 \mathrm{~m}$ de altitude. São crepusculares de voo rápido e até aproximadamente $3 \mathrm{~m}$ do solo. Exibem comportamento territorial, os machos brigam por determinados pontos na vegetação.

Planta hospedeira e imaturos. MÜLLER (1886), FRUHSTORFER (1912), BATES (1932), SILVA et. al. (1968), ZIKÁN \& ZIKÁN (1968) e PENZ et al. (2000) citam para a espécie, Bambusa sp. (Poaceae).

Sobre os imaturos MÜLLER (1886) faz referência a uma única largarta por ele encontrada, próxima de empupar, com $6 \mathrm{~cm}$ de comprimento ou $7,5 \mathrm{~cm}$, se incluida a cauda. Cabeça marrom com três pares de chifres. O corpo vermelho pálido e marrom acinzentado com linhas foscas e onduladas. A pupa, ventralmente com os segmentos abdominais bastante comprimidos. BATES (1932) cita características comuns para as larvas de Brassolis, Caligo, Dynastor, Eryphanis, 
Narope e Opsiphanes onde as larvas possuem escolos na cabeça, em número de quatro pares, sendo apenas os dois medianos desenvolvidos; o corpo é estreito, de cor marrom ou verde com linhas longitudinais e as projeções da cauda são desenvolvidas, exceto para Brassolis.

Material estudado. BRASIL, Minas Gerais: Caxambú, 1 macho (UFPC); Rio de Janeiro: Rio de Janeiro, Jacarepaguá, 1 fêmea, 25.IV.1920, 1 macho, 11.XI.1921, D'Almeida leg. (UFPC); Guapimirim, 1 macho, 19.VI.1938 (UFPC); Rio de Janeiro, 2 machos, 7.IX.1958 e 10.IX.1965, Mielke leg. (OM), 1 fêmea, 19.X.1965, 1 macho, 25.IX.1965 (KB), 2 machos, 30.III.1967 (UFPC), 6 machos, (2) 28.VIII.1967, (2) 19.VI.1971, (2) 25.VII.1971, Brown leg. (KB), 1 macho e 1 fêmea (USMN), Rio de Janeiro, Gávea, 1 macho, 18.IV.1971, Callaghan leg. (AME), Rio de Janeiro, Morro Dona Marta, 200m, 1 fêmea, 14.V.1936, Gagarin leg. (UFPC); Duque de Caxias, Km 16, estrada Rio-Petrópolis, 1 macho e 1 fêmea, 22.V.1972, Callaghan leg. (AME); Xerém, 1 macho, 3.X.1976, Brown leg. (KB); Imbariê, 25 m, 1 fêmea, 22.II.1967, Ebert leg. (UFPC); São Paulo: Rio Claro, 600m, 1 fêmea, 12.IV.1967, Ebert leg. (UFPC); Paraná: Rio das Cobras, 2 machos e 2 fêmeas, II.1942, Widerski leg. (UFPC), 1 macho, Justus leg. (UFPC), Rolandia, Rio Tibagi, 12.VIII.1957, Walz leg. (UFPC), Porecatu, 1 macho, 20.X.1970, Becker leg. (UFPC); Santa Catarina: Joinville, 1 macho e 1 fêmea, 10.X.1968, 25.V.1980, Miers leg. (UFPC), 2 machos, (AMNH); Seara, Nova Teotônia, 300 m, 1 macho, 1.V.1979, 2 fêmeas, I.1963, III.1966, Plaumann leg. (UFPC); Rio Grande do Sul: Guarany, São Luiz de Gonzaga, 1 macho, 21.XII.1939, 1 macho, Biezanko leg. (UFPC), 1 macho, 8.I.1954, Biezanko leg. (CU), São Leopoldo, 1 fêmea, 5.I.1966, Dendisch leg. (UFPC).

\section{Narope cyllene C. Felder \& R. Felder, 1859}

\section{Figs $34-38$}

Narope cyllene C. Felder \& R. Felder, 1859. Wien. ent. Monatschr. 3: 270; 1 fêmea [holótipo], Brasil ?.- Herrich-Schäffer, 1865. Corr.- Blatt zool.-min. Ver. Regensburg 19: 65; cit.- Kirby, 1871. Syn. Cat. Diurn. Lep., p. 129; cat.- Staudinger, 1887, in Staudinger \& Schatz. Exot. Schmett. 1, p. 218; sist.- Glaser, 1887. Cat. etymol. Col. Lep., p. 302; cit., etimologia.- Casagrande, 1991. Revta bras. Zool. 7: 130, Figs 1-4 (macho, fêmea d, v), 9, 10 (venação), 12-16 (gen. masc.), 17 (gen. fem.), 18-30 (ovo, larva, pupa); biologia, planta hosp., dg.

Histórico. Na descrição original, os autores, FELDER \& FELDER (1859) indicam que o único exemplar que possuem, provavelmente é do Brasil e o comparam com as outras espécies já descritas para o gênero. STICHEL (1932) sinonimiza com $N$. cyllastros. CASAGRANDE (1991) revalida a espécie, redescreve $\mathrm{o}$ adulto e apresenta dados sobre os imaturos.

Material tipo. Como a descrição original é clara no que diz respeito ao número de exemplares, considerou-se o exemplar fêmea da coleção do "The Natural History Museum" Londres, Inglaterra como HOLÓTIPO. O exemplar possui as seguintes etiquetas: /cyllene n./ Felder Coll./ Narope cyllene 1 Südamer in Coll. Felder/ HOLOTYPE/ Narope cyllene C. Felder \& R. Felder, 1859, Holotype, M.M. Casagrande det. 2002/. 
Diagnose. Face dorsal das asas anterior e posterior castanho escuro sem manchas ou faixas de outra cor. Androcônia da asa posterior $1 / 4$ do tamanho daquela da face ventral da asa anterior. Faixa basal da asa posterior desde a margem costal até $2 \mathrm{~A}$. Genitália masculina com valva em ponta e face dorsal do unco com espinhos.

Descrição. Macho (Figs 34, 36). Asa anterior: comprimento da margem costal - 31 a $33 \mathrm{~mm}$; margem externa - 20 a $22 \mathrm{~mm}$; largura da asa - 19 a $21 \mathrm{~mm}$. Asa posterior: comprimento da margem costal - 19 a $21 \mathrm{~mm}$; margem externa: 21 a $23 \mathrm{~mm}$; maior comprimento da asa -22 a $25 \mathrm{~mm}$.

Dorsalmente a cabeça e os palpos, tórax e abdome castanho escuro, ventralmente castanho claro. Antenas ferrugíneas.

Face dorsal das asas anterior e posterior castanho escuro, contornada por estreita margem enegrecida, no ápice da asa anterior desde a bifurcação $\mathrm{R}_{4}-\mathrm{R}_{5}$; androcônia arredondada, de tamanho pequeno, creme, pouco além bifurcação de Rs-M $M_{1}$, sobre Rs. $\mathrm{CuA}_{1}$ se prolonga de forma a acrescentar uma projeção acentuada ao contorno da asa.

Face ventral da asa anterior, castanho médio, pouco ferrugínea, com manchas castanho escuras. Do ápice até o meio da margem interna, uma faixa mais clara que o restante da asa. Desta faixa até a base da asa, com exceção da célula discal, algumas escamas claras e metálicas dão o aspecto levemente violáceo sobre o castanho, enquanto o restante distal é opaco. Faixa basal restrita ao espaço da célula; pós-basal desde o meio da margem costal, passando sobre as discocelulares até a base de 2A. Sobre a metade basal de $2 \mathrm{~A}$, androcônia com escamas creme, quatro vezes maior que aquela da face dorsal da asa posterior. Sobre estas escamas, um pincel de pêlos, distribuídos de forma linear sobre uma prega formada pela margem interna da asa. A extensão da faixa de pêlos corresponde ao tamanho da mancha.

$\mathrm{Na}$ face ventral da asa posterior o efeito violáceo também está presente em uma faixa nas margens anal e externa. Entre estas, as cores são opacas e as linhas claras e escuras se sucedem. Nitidamente pode-se destacar uma faixa clara, obliqua do meio da margem interna até $2 \mathrm{~A}$, que separa a faixa basal da pós-basal, ambas escuras.

Genitália (Fig. 36A-E). Unco curvo distalmente e com numerosos espinhos na face dorsal. Subunco desenvolvido, retangular, projetado dorsalmente e em ponta. Extremidade distal da valva com três projeções anteriores distintamente marcadas e outra distal, ponteaguda, que se projeta para além da terminação do unco. Juxta, em vista ventral, com forma de losângulo e suave depressão na borda superior.

Fêmea (Figs 35, 37). Asa anterior: comprimento da margem costal -29 a 36 $\mathrm{mm}$; margem externa - 20 a $26 \mathrm{~mm}$; largura da asa - 19 a $25 \mathrm{~mm}$. Asa posterior: comprimento da margem costal -21 a $25 \mathrm{~mm}$; margem externa -21 a $26 \mathrm{~mm}$; maior comprimento da asa -26 a $32 \mathrm{~mm}$.

Fêmeas com a mesma coloração das asas que os machos, sendo que ventralmente as manchas e faixas são menos evidentes. $\mathrm{O}$ ápice da asa anterior é retraído em relação à parte mediana da margem externa e nas asas posteriores, na margem externa, a maior projeção da asa é acompanhada pela $\mathrm{M}_{3}$ e não pela $\mathrm{CuA}_{1}$, como nos machos. 

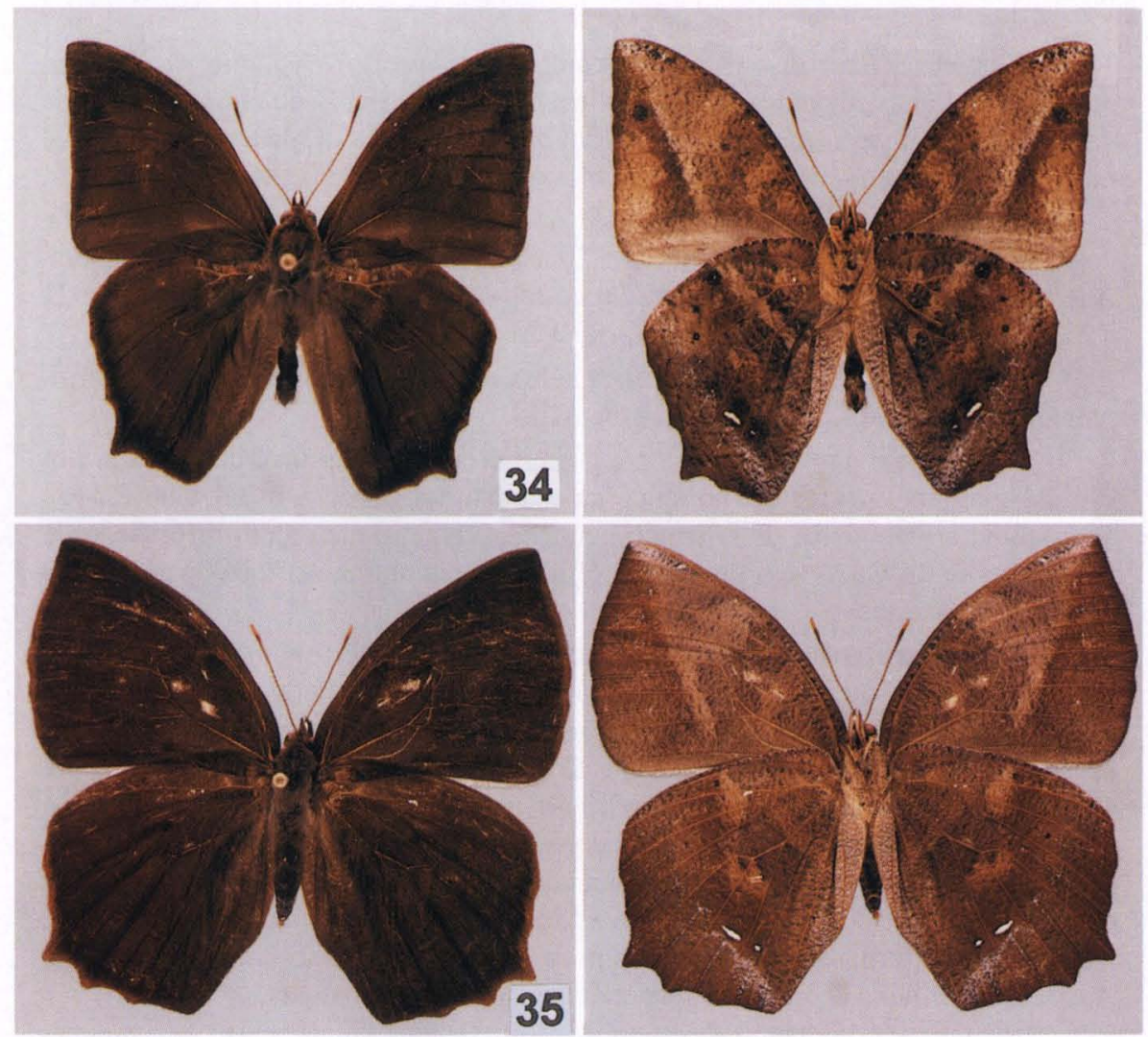

Figs 34-35. Narope cyllene. (34) Macho, vistas dorsal e ventral; (35) fêmea, vistas dorsal e ventral.

Genitália (Fig. 37). Lamela pós-vaginal em forma de placa esclerotinizada com projeções látero-distais, no centro e distalmente com projeção em forma de "T". Anteriormente finas linhas esclerotinizadas do oitavo segmento convergem para a formação de uma placa central, a lamela ante-vaginal. O duto da bolsa se alarga progressivamente constituindo a mesma.

Discussão. Aproxima-se de N. cyllastros e de N. guilhermei. Separa-se da última pela ausência da cor amarelo-ferrugíneo da face dorsal das asas, pela ausência de carena na face interna da valva e aspectos do unco e subunco. Separa-se de $N$. cyllastros principalmente pela diferença no tamanho da androcônia da face dorsal da asa posterior, em $N$. cyllene, bem menores e, ventralmente pelas faixas na asa posterior.

Distribuição espacial (Fig. 38). BRASıL, Minas Gerais: Passa Quatro, Manhuaçu; Espírito Santo: Santa Tereza; Rio de Janeiro: Petrópolis, Teresópolis (Parque Nacional), Itatiaia (Parque Nacional); São Paulo: São José do Barreiro (Serra da Bocaina), Campos do Jordão (Umuarama), Teodoro Sampaio (Parque 


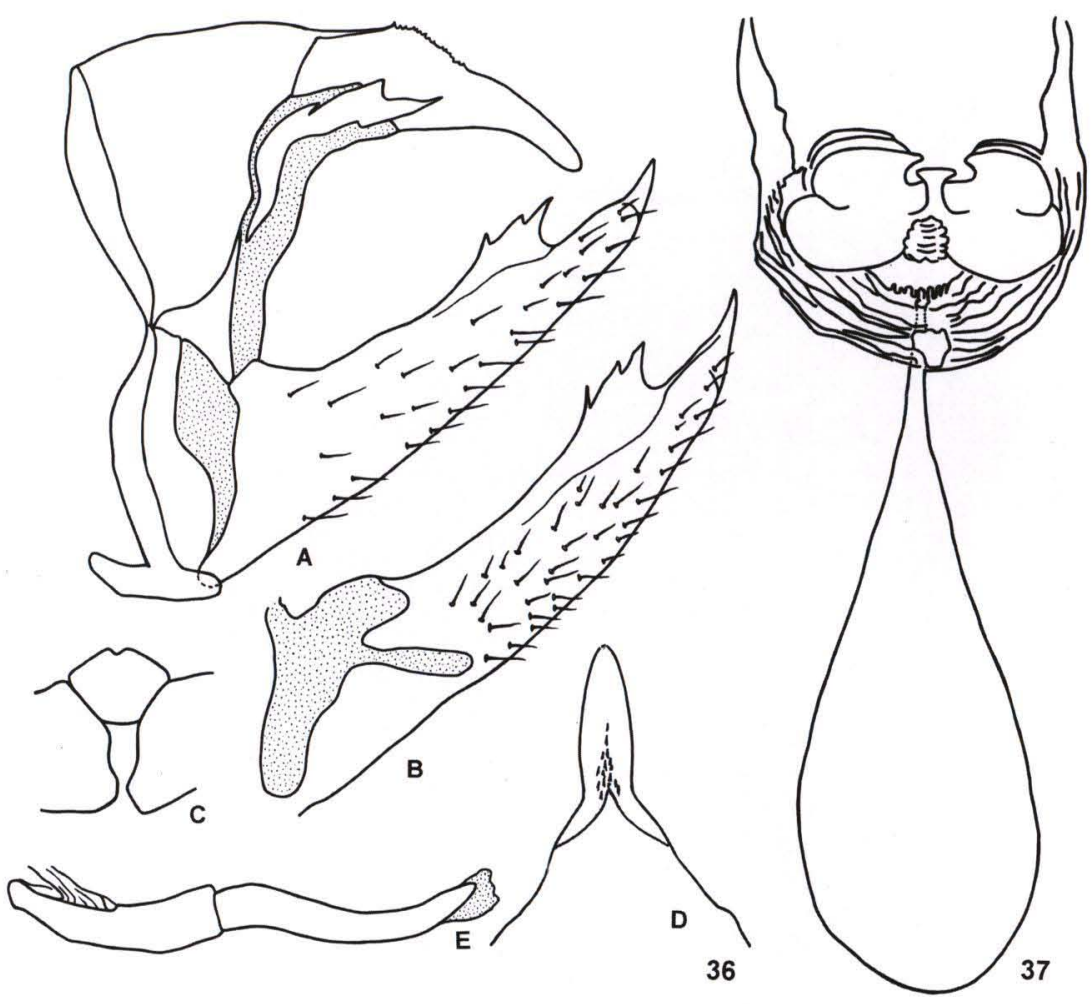

Figs 36-37. Narope cyllene. (36) Genitália masculina: (A) vista lateral, (B) valva, vista lateral interna, (C) juxta, vista ventral, (D) tegume/unco, vista dorsal, (E) edeago, vista lateral; (37) genitália feminina, vista ventral.

Estadual do Morro do Diabo), Apiaí, Piquete (Barreira); Paraná: Curitiba, São Luiz do Purunã, Bituruna, Mafra, Tijucas do Sul (Vossoroca, Rincão); Santa Catarina: São Bento dos Sul (Rio Natal, Rio Vermelho).

Distribuição temporal. Voa durante os meses de outubro e de dezembro a junho.

Etologia. Voa em locais com altitudes acima de $300 \mathrm{~m}$.

Planta hospedeira e imaturos. As larvas alimentam-se de Chusquea leptophylla Nees (Poaceae). Permanecem na planta durante todo o desenvolvimento até a eclosão dos adultos. As fêmeas ovipositam grupos de ovos nas axilas das folhas e as larvas levam aproximadamente oito dias para eclodir. Da primeira até a terceira idade, permanecem uma em cada folha, tanto nas faces dorsal como ventral da mesma. Alimentam-se pela manhã e ao entardecer. Nas quarta e quinta idades preferem os talos principais onde permanecem grande parte do dia com a cabeça voltada para a parte inferior da planta, entre as ramificações. A camuflagem é notável, pois as linhas beges do corpo confundem-se com a bainha seca do bambú e os escolos da cabeça com os râmulos. Quando na fase de pupa, os últimos segmentos abdominais ficam dorsalmente paralelos ao substrato escolhido para se pendurar. 


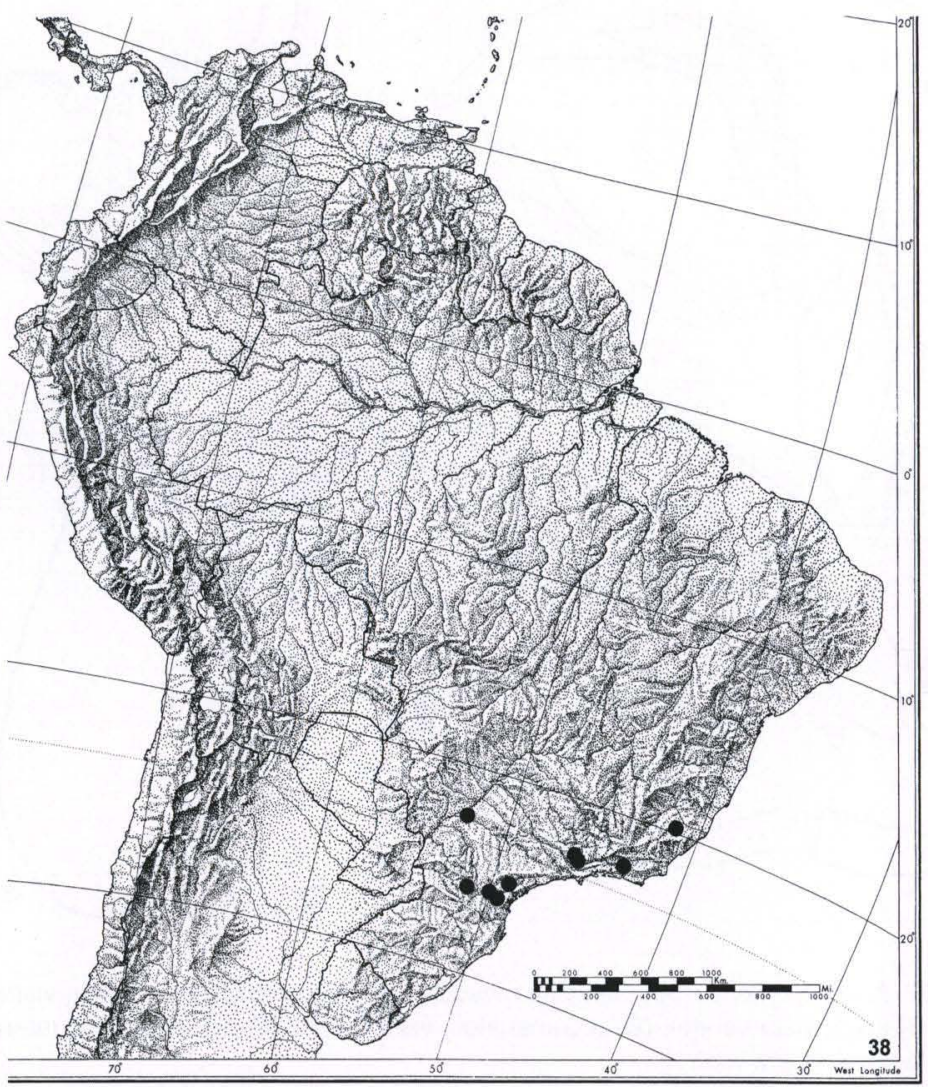

Fig. 38. Narope cyllene, distribuição espacial.

Material estudado. BRASIL, 1 fêmea (holótipo) (BMNH). Minas Gerais: Passa Quatro, Fazenda dos Campos, 1 fêmea, 2.VI.1929, Zikán leg. (MNRJ); Manhuaçu, Parque Nacional do Caparaó, 1500m, 1 fêmea, 6-8.II.1987, Mielke \& Casagrande leg. (UFPC). Espírito Santo: Santa Tereza, 1 macho, 12.V.1970, Brown leg. (KB). Rio de Janeiro: Petrópolis, 800 m, 1 macho, 1.XII.1958; 1100m, 3 machos, 21.II.1966 e 1 macho, 9.IV.1971, Ebert leg. (UFPC); Teresópolis, Parque Nacional da Serra dos Órgãos, 1500 m, 2 machos, 30.IV.1962, Mielke leg. (OM), 1000m, 2 machos, 2.IV.1965, (OM) (UFPC). Itatiaia, Parque Nacional do Itatiaia, 1000 m, 2 machos, 2.V.1965, Brown leg. (KB), Itatiaia, 1 fêmea, 10.II.1966, Brown leg. (KB), Itatiaia, Serra do Itatiaia, $1700 \mathrm{~m}, 1$ macho, 16.I.1969, Ebert leg. (UFPC). São Paulo: Campos do Jordão, Umuarama, 1800 m, 2 fêmeas, 8-15.III.1937, Gagarin leg. (UFPC). Campos do Jordão, 1700 m, 1 fêmea e 5 machos, 24-31.I.1966, Ebert leg. (UFPC), São José doBarreiro, Serra da Bocaina, 1 macho, 2-4.III.1967, 
Ebert leg. (UFPC). Apiaí, 2 fêmeas, IV.1972, Ebert leg. (UFPC), Piquete (Barreira), 1400-1600 m, 1 macho, 15.II.1984, Mielke \& Casagrande leg. (UFPC), Teodoro Sampaio, Parque Estadual Morro do Diabo, 350-500 m, 1 macho, 20-23.II.1990, Mielke \& Casagrande leg. (UFPC). Paraná: Curitiba, 1 macho, III.1946 (UFPC). São Luiz do Purunã, 1000 m, 1 macho 15.II.1990, Mielke \& Casagrande leg. (UFPC), Bituruna, 4 machos, 10-25.III.1966, Staviarsky leg. (OM). Mafra, 850 m, 1 macho, 22.II.1982, Mielke leg. (UFPC). Tijucas do Sul, Rincão, 1 fêmea, 25.II.1969, Mielke leg. (UFPC), Vossoroca, 850 m, 4 machos, 8.III.1981, Mielke leg. (UFPC), X-2000, 3 machos, Mielke \& Casagrande leg. (UFPC). Santa Catarina: São Bento do Sul, 1 fêmea, 5.II.1969 e 1 macho, 3.X.1971, Ebert leg. (UFPC), São Bento do Sul, Rio Vermelho, 850 m, 1 fêmea, 10.II.1973, 2 machos, 13.II.1980, 1 macho, II.1980, 1 macho e 5 fêmeas, III.1980, 1 macho, 8.III.1980, 1 macho, 28.III.1980, 1 macho, 2.I.1982, 1 macho, 18.I.1982, 1 macho, 27.I.1982, 1 macho, 31.I.1982, 1 fêmea, 12.II.1982, 1 macho, 18.II.1982, 3 machos, 21.II.1982, 1 fêmea, 25.III.1982, 1 macho, 12.III.1985, 1 macho e 1 fêmea, 30.III.1985, Rank leg. (UFPC); 3 machos e 1 fêmea, 24.VI.1988, 1 macho, 26.VI.1988, Mielke leg. (UFPC); São Bento do Sul, Rio das Antas, 1 macho, 19.III.1982, Miers leg. (UFPC); São Bento do Sul, Rio Natal, 500 m, 1 macho, 1.III.1982, 2 machos, 2.II.1982, 1 macho, 10.III.1984, Rank leg. (UFPC).

\section{Narope cyllarus Westwood, 1851}

Figs $39-43$

Narope cyllarus Westwood, 1851, in Doubleday. Gen. Diurn. Lep. 2, p. 349; Rio River [Rio de Janeiro, Brasil], América do Sul; Museu Hewitson.-Herrich-Schäffer, 1865. Corr.-Blatt zool--min. Ver. Regensburg 19: 65; cit.- Kirby, 1871. Syn. Cat. Diurn. Lep., p. 129; cat.- Staudinger, 1887, in Staudinger \& Schatz. Exot. Schmett. 1, p. 218; sist., dg.- Bönninghausen, 1896. Verh. Ver. naturw. Unterh. Hamburg 9: 39; dg.- Stichel, 1904, in Wytsman. Gen. Ins. 20, p. 15, pl. 4, fig. 1 (macho d, v); cat., dg.- Stichel, 1909. Tierreich 25, p. 42, 44; cat., sist., dg.- Fruhstorfer, 1912, in Seitz. Gross-Schmett. Erde 5, p. 328, pl. 62 ([macho] d); sist., dg.- Zikán, 1928. Ent. Rdsch. 45: 11; dg.- Stichel, 1932. Lep. Cat. 51, p. 15; cat., dg.- Hemming, 1941. Jour. Soc. Bibl. Nat. Hist. 1(2): 451; sist., dg.- Hayward, 1951. Acta zool. lill. 9: 219; cat., dg.- J. Zikán \& W. Zikán, 1968. Pesq. agropec. bras. 3: 50; dg.- Hayward, 1973. Op. lill. 23: 241; cat., dg.- Lewis, 1973. Butt. World, p. 222; dg.- Lewis, 1975. Marip. Mundo, p. 222; dg.- D'Abrera, 1987. Butt. Neotrop. Reg 3, p. 392, figs (macho d, v); sist., dg.- Casagrande \& Mielke, 1993. Revta bras. Zool. 9: 84, fig. 10 (macho, fêmea d, v); dg.- Casagrande \& Mielke, 1995, in Paraná, SEMA. Lista verm. Anim. ameaç. Extinção Est. Paraná, p. 148; dg.- Casagrande, 1996. Revta bras. Zool. 12: 686, Fig. (gen. masc.); sist.- Peracchi et al. 1998, in Bergallo. Diário Oficial, Estado do Rio de Janeiro, 24(102), parte I, p. 11; dg.- Bergallo et al., 2000. Fauna ameaç. ext. Estado Rio de Janeiro, p. 54, dg.

Histórico. WESTWOOD (1851), ao citar a distribuição geográfica da espécie tipo do gênero, Narope cyllastros, até então somente figurada, inclui duas novas espécies: Narope cyllabarus da Bolívia e N. cyllarus de River Rio, South America.

As citações que seguem à descrição original, ampliam a distribuição geográfica para outros estados do Brasil, das Regiões Sul e Leste. CASAGRANDE \& MIELKE $(1995,1996)$ a incluem na lista de espécies ameaçadas de extinção no Estado do Paraná, e PERACCHI et al. (1998 in BERGALlo et al. 2000) na lista de espécies ameaçadas de extinção no Estado do Rio de Janeiro. 
Material tipo. Como na descrição original não há referência ao número de exemplares, a fêmea encontrada no "The Natural History Museum", Londres, Inglaterra, é aqui designada como LECTÓTIPO, com o objetivo de garantir a adequada identificação da espécie, com as seguintes etiquetas: /Type/ Rio R/ Rio River, Hewitson Coll., 79-69, Narope cyllarus Westw/ /cyllarus/ B.M. TYPE, N ${ }^{\circ}$ Rh 6117, Narope cyllarus, fêmea Westw/ LECTOTYPE/ Narope cyllarus Westwood, 1851, Lectotype, M.M. Casagrande det. 2002/

Diagnose. Face dorsal das asas anterior e posterior castanho claro ferrugíneo. Linha submarginal denteada e enegrecida contorna toda a margem externa em ambas as asas. Pequeno ponto da mesma cor da faixa e pouco antes dela, entre $\mathbf{M}_{1}-\mathrm{M}_{2}$. Genitália masculina com a valva contornada na extremidade distal externa por projeções denteadas e na face interna, com depressão e numerosos dentes.

Descrição. Macho (Figs 39 e 41). Asa anterior: comprimento da margem costal - 27 a $29 \mathrm{~mm}$; margem externa - 18 a $20 \mathrm{~mm}$; largura da asa - 17 a $19 \mathrm{~mm}$. Asa posterior: comprimento da margem costal - 16 a $18 \mathrm{~mm}$; margem externa - 19 a $21 \mathrm{~mm}$; maior comprimento da asa - 22 a $24 \mathrm{~mm}$.

Cabeça e apêndices, tórax e abdome castanho claro ferrugíneo, pouco mais claro ventralmente.

Face dorsal das asas anterior e posterior castanho claro ferrugíneo. Linha submarginal denteada, enegrecida e contornando toda a margem externa em ambas as asas. Pequeno ponto da mesma cor da faixa e pouco antes dela, entre $\mathrm{M}_{1}-\mathrm{M}_{2}$. Sobre a base de $\mathrm{M}_{1}, \mathrm{M}_{2}$, fora e dentro da célula discal, e sobre a parte média da discocelular inferior, escamas castanho ferrugíneo intenso, formam pequenas manchas. $\mathrm{Na}$ asa posterior, estas escamas de mesma coloração também sobre a base de $\mathrm{M}_{3}$, dentro da célula discal, formando uma pequena mancha de aspecto arredondado; androcônia oval de tamanho médio, creme, pouco além da Rs-M1, sobre Rs. $\mathrm{CuA}_{1}$ se extende de forma a acrescentar uma projeção acentuada ao contorno da asa.

Face ventral das asas castanho claro e pardo, contornado por finas linhas enegrecidas. Linha submarginal denteada como na face dorsal. Uma segunda linha, pós-mediana, com a mesma cor. Do ápice da asa anterior até pouco antes do meio da margem interna, faixa obliqua enegrecida. Faixa basal estreita e pós-basal três vezes

mais larga. Sobre a metade proximal de $2 \mathrm{~A}$, androcônia com escamas ferrugíneas, de igual tamanho que aquela da face dorsal da asa posterior. $\mathrm{Na}$ asa posterior faixa basal obliqua enegrecida da metade proximal da margem costal até o primeiro terço de $2 \mathrm{~A}$. Igualmente obliqua e com a mesma coloração, faixa pós-basal, desde a metade distal da célula discal até pouco além de $\mathrm{CuA}_{2} \mathrm{e}$ antes de 2A. Estas duas faixas unidas na base de Rs-M $\mathrm{M}_{1}$ e contornadas por escamas brancas, com reflexo prateado.

Genitália (Fig. 41 A-E). Unco afilado e projetado para além da parte distal da valva. Subunco retangular, com a porção distal revestida de espinhos. Valva contornada na extremidade distal por projeções denteadas, na face interna, com depressão e numerosos dentes. Juxta, em vista ventral, em forma de $\mathrm{U}$.

Fêmea (Figs 40 e 42). Asa anterior: comprimento da margem costal - 29 a $34 \mathrm{~mm}$; margem externa - 19 a $23 \mathrm{~mm}$; largura da asa - 19 a $22 \mathrm{~mm}$. Asa posterior: 

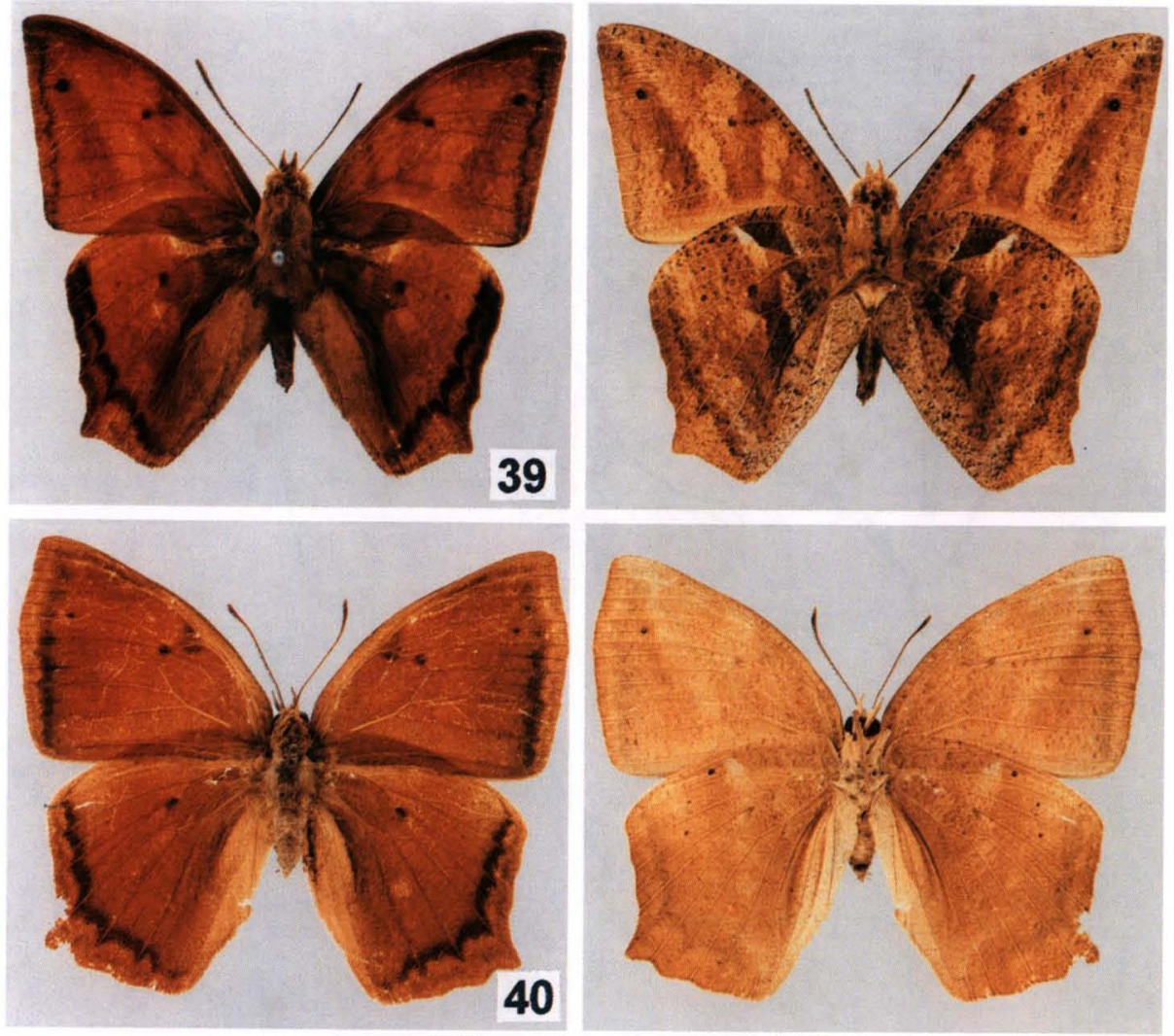

Figs 39-40. Narope cyllarus. (39) Macho, vistas dorsal e ventral; (40) fêmea, vistas dorsal e ventral.

comprimento da margem costal - 21 a $25 \mathrm{~mm}$; margem externa -21 a $25 \mathrm{~mm}$; maior comprimento da asa - 26 a $29 \mathrm{~mm}$.

Coloração geral e desenhos na face dorsal das asas igual aos machos. $\mathrm{M}_{3}$ se extende acrescentando projeção acentuada ao contorno alar.

Face ventral de ambas as asas, em tons mais claros que a face dorsal, não possui reflexo prateado e toda a superfície pontuada de pequenos aglomerados de escamas mais escuras.

Genitália (Fig. 42). Lamela pós-vaginal formada por placa triangular esclerotinizada e com extremidades arredondadas. Lamela ante-vaginal, um quinto do tamanho da pós-vaginal e de tênue esclerotinização. Duto e bolsa distintos, com praticamente o mesmo tamanho; bolsa arredondada.

Discussão. Facilmente reconhecida pela coloração das asas e pela linha submarginal enegrecida em ambas as asas. Eventualmente pode ser confundida com Narope testacea, porém pode ser facilmente distinta pela distribuição geográfica, pois $N$. cyllarus ocorre exclusivamente no Brasil e norte da Argentina, enquanto $N$. testacea exclusivamente na América Central. 


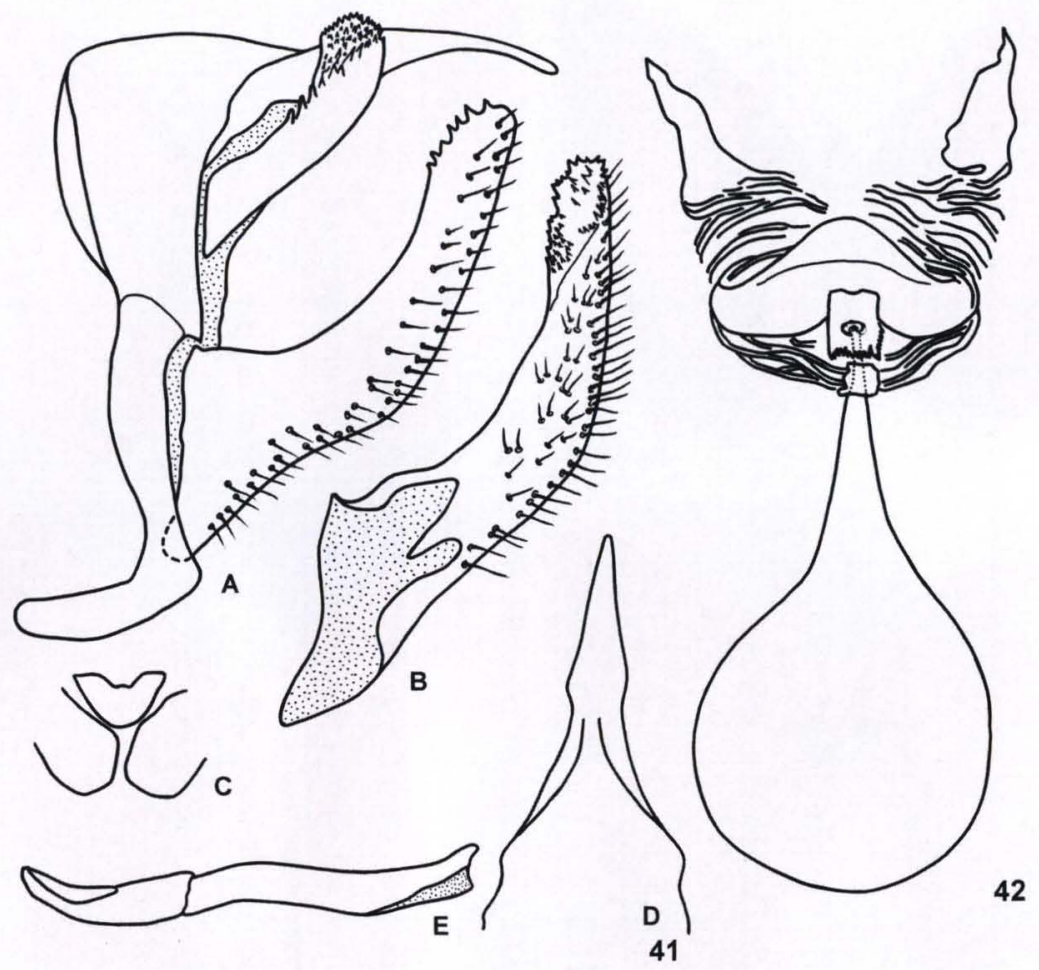

Figs 41-42. Narope cyllarus.(41) Genitália masculina: (A) vista lateral, (B) valva, vista lateral interna, (C) juxta, vista ventral, (D) tegume/unco, vista dorsal, (E) edeago, vista lateral; (42) genitália feminina, vista ventral.

Distribuição espacial (Fig. 43). BRASIL, Espirito Santo; Rio de Janeiro: Itatiaia, Guapimirim, Rio de Janeiro; Paraná: Foz do Iguaçu; Santa Catarina: Joinville, São Bento do Sul (Rio Natal). ARGENTINA, Missiones.

Distribuição temporal. Voa nos meses de dezembro a abril.

Etologia. Desconhecida.

Planta hospedeira e imaturos. Desconhecida, mas acredita-se que as larvas devam alimentar-se de Poaceae.

Material estudado. BrASIL, Espírito Santo: 1 macho (CU). Rio de Janeiro: 1 macho, Rio River (LECTÓTIPO) (BMNH); Itatiaia, 800 m, 1 macho, 15.I.1925, J.F. Zikán leg. (MNRJ); 700 m, 1 fêmea, 6.IV.1973, Ebert leg. (UFPC); Guapimirim: 1 macho, 15.X.1940 (OM); 1 macho, 20.VII.1941 (UFPC). Santa Catarina: Joinville, 1 macho, XII.1965, Miers leg. (OM); São Bento do Sul, 1 macho, 12.I.1972 (UFPC); São Bento do Sul, Rio Natal, 300 m, São bento do Sul, 9 machos, 11.VI, 12.VII, 19.VII, 10.VIII, 12.VIII, 13.IX e 20.IX.2001, Lino Rank leg. (CGCM), 1 macho, 23.I.1993 (Col. Jordano Harro). 


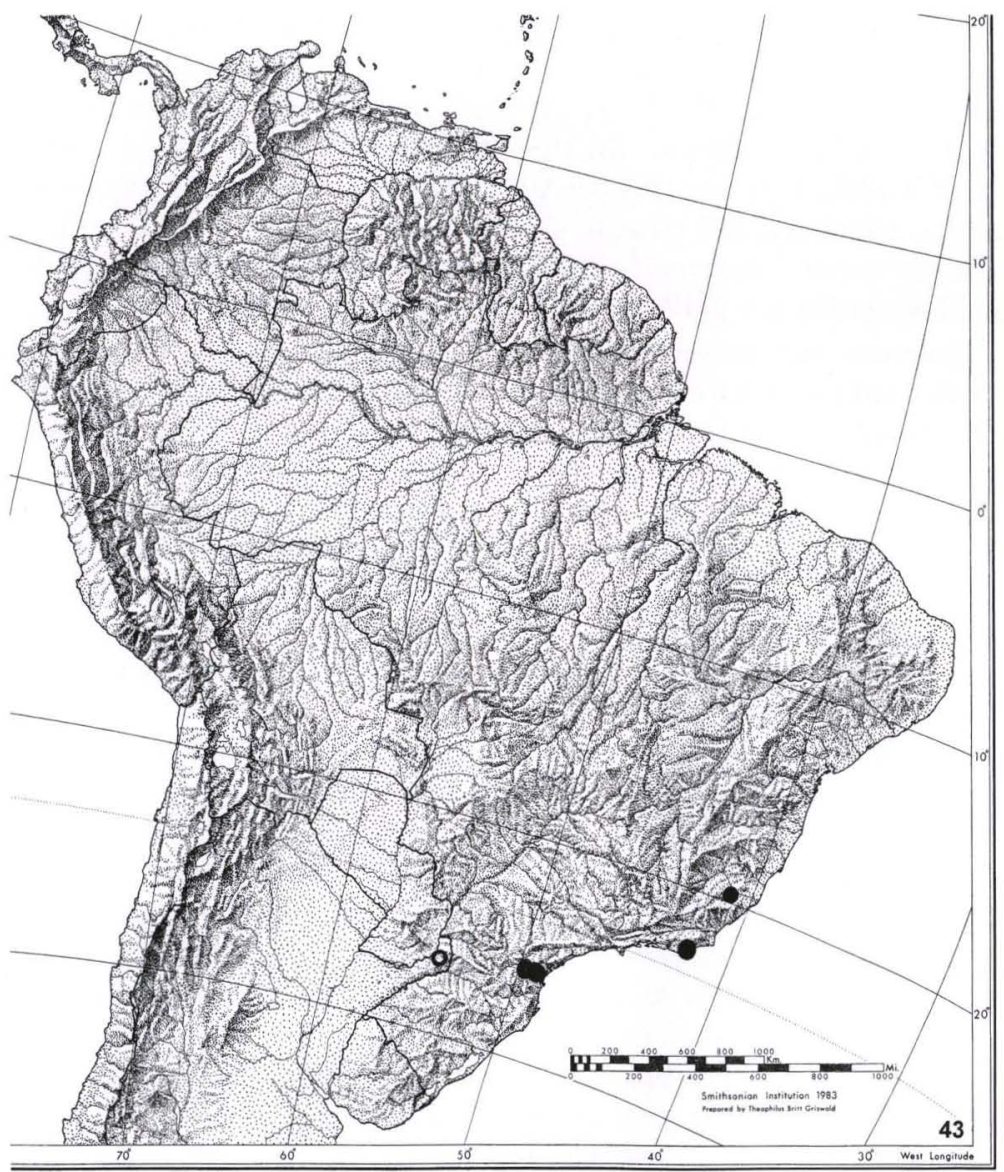

Fig. 43. Narope cyllarus, distribuição espacial.

\section{Narope guilhermei Casagrande, 1989}

Figs 44, 45, 47, 48 e 54

Narope guilhermei Casagrande, 1989. Revta bras. Zool. 6: 126, figs 1-4 (macho, fêmea d, v), 5, 6 (venação), 7-11 (gen. masc.), 12, 13 (gen. fem.); holótipo macho, 24-I-1986, Rio Negrinho, Santa Catarina, Brasil, C. G. Mielke leg.; Departamento de Zoologia, Universidade Federal do Paraná.

Material tipo. HOLÓTIPO depositado na Coleção Padre Jesus Santiago Moure do Departamento de Zoologia da Universidade Federal do Paraná, com as seguintes etiquetas: /Holótipo/ 24.I.1986, Rio Negrinho, SC, C.G. Mielke leg./DZ 3071/ Narope guilhermei Casagrande, M. Casagrande det. 1988, Holótipo/. ALÓ- 
TIPO fêmea, também depositado na mesma coleção com as seguintes etiquetas: /Alótipo/ 27.I.1986, Rio Negrinho, SC, C.G. - O. Mielke leg./ DZ 3072/ Narope guilhermei Casagrande, M. Casagrande det. 1988, Alótipo/. PARÁTIPOS - BRASIL, Santa Catarina: Rio Negrinho, 1 macho, 18.I.1984, C.G. Mielke leg. (CGM), 1 macho, 18.I.1984, C.G. Mielke leg. (UFPC); 3 machos e 1 fêmea, 24.I.1986, C.G. Mielke leg. (UFPC); 1 fêmea, 24.I.1986, C.G.Mielke leg. (CGM), 2 machos e 4 fêmeas, 27.I.1986, C.G.- O. Mielke leg. (UFPC); 1 macho, 27.I.1986, C.G.- O. Mielke leg. (BMNH); Rio Grande do Sul: Caxias do Sul, 1 fêmea, 15.II.1896 (identificado como cyllabarus?) (FZRS), todos etiquetados como parátipos da seguinte forma:/ Narope guilhermei Casagrande, M. Casagrande det. 1988/.

Diagnose. Face dorsal da asa anterior em laranja ferrugíneo. A cor castanho escura está restrita ao ápice e margens externa e interna da asa anterior. Asa posterior, castanho escuro com faixa marginal laranja ferrugíneo. Na fêmea a área laranja ferrugíneo reduzida a uma mancha, além da célula discal e em amarelo ferrugíneo.

Descrição. Macho (Figs 44 e 47). Asa anterior: comprimento da margem costal - 31 a $33 \mathrm{~mm}$; margem externa - 19 a $22 \mathrm{~mm}$; largura da asa - 19 a $22 \mathrm{~mm}$. Asa posterior: comprimento da margem costal -19 a $22 \mathrm{~mm}$; margem externa - 19 a $22 \mathrm{~mm}$; maior comprimento da asa -24 a $28 \mathrm{~mm}$.

Cabeça e tórax, dorsal e ventralmente, castanho claro ferrugíneo; abdome castanho escuro. Antenas ferrugíneas.

Face dorsal da asa anterior, desde a bifurcação R4-R5 até o ápice castanho escuro. Esta área se estreita progressivamente até o ápice de $\mathrm{CuA}_{2}$. $\mathrm{Da} \mathrm{CuA}_{1}$ até a base de $2 \mathrm{~A}$, fora da célula discal, castanho. Célula discal e todo restante da asa ferrugíneo. Margem externa com faixa ferrugínea de $1 \mathrm{~mm}$ de largura.

Face dorsal da asa posterior castanho, contornada desde $\mathrm{Sc}+\mathrm{R}_{1}$ até $2 \mathrm{~A}$ por faixa ferrugínea, com a mesma espessura daquela da asa anterior; androcônia arredondada, de tamanho pequeno, creme, pouco além da bifurcação de Rs-Ml, sobre Rs.

Face ventral da asa anterior castanho claro com faixas castanho escuro. Duas destas faixas, a basal e a pós-basal, atravessam a célula discal de forma oblíqua, no sentido margem costal - margem interna, terminando pouco antes da última. Outra faixa, da mesma cor que as anteriores, ocupa o espaço entre uma mancha redonda, preta, localizada entre $\mathrm{M}_{1}-\mathrm{M}_{2}$ e próxima à margem externa, alargando-se progressivamente até o centro da margem interna e ápice de $2 \mathrm{~A}$. Sobre a metade proximal de $2 \mathrm{~A}$, androcônia oval, com escamas creme e o dobro do tamanho daquela da face dorsal da asa posterior.

Face ventral da asa posterior castanho claro. Pequena mancha castanho escura e redonda no centro da margem costal. Entre $\mathrm{Sc}+\mathrm{R}_{1} \mathrm{e} \mathrm{Rs}$, três faixas paralelas, dispostas da margem costal até a margem anal. A basal, mais larga, afila progressivamente até o terço proximal de $2 \mathrm{~A}$ e as pós-basal e mediana, com a mesma espessura, terminam no segundo terço de $2 \mathrm{~A}$ e na porção distal de $2 \mathrm{~A}$, respectivamente. Ainda dessa mesma mancha escura, parte uma série de outras manchas submarginais, formando um semi-círculo, seguindo o contorno alar até $2 \mathrm{~A}$; as duas primeiras castanho escuro com o centro creme, as quatro seguintes creme, sendo a penúltima maior e em meia lua. No ângulo anal, uma faixa branca difunde-se progressivamente até próxima à penúltima mancha creme. 

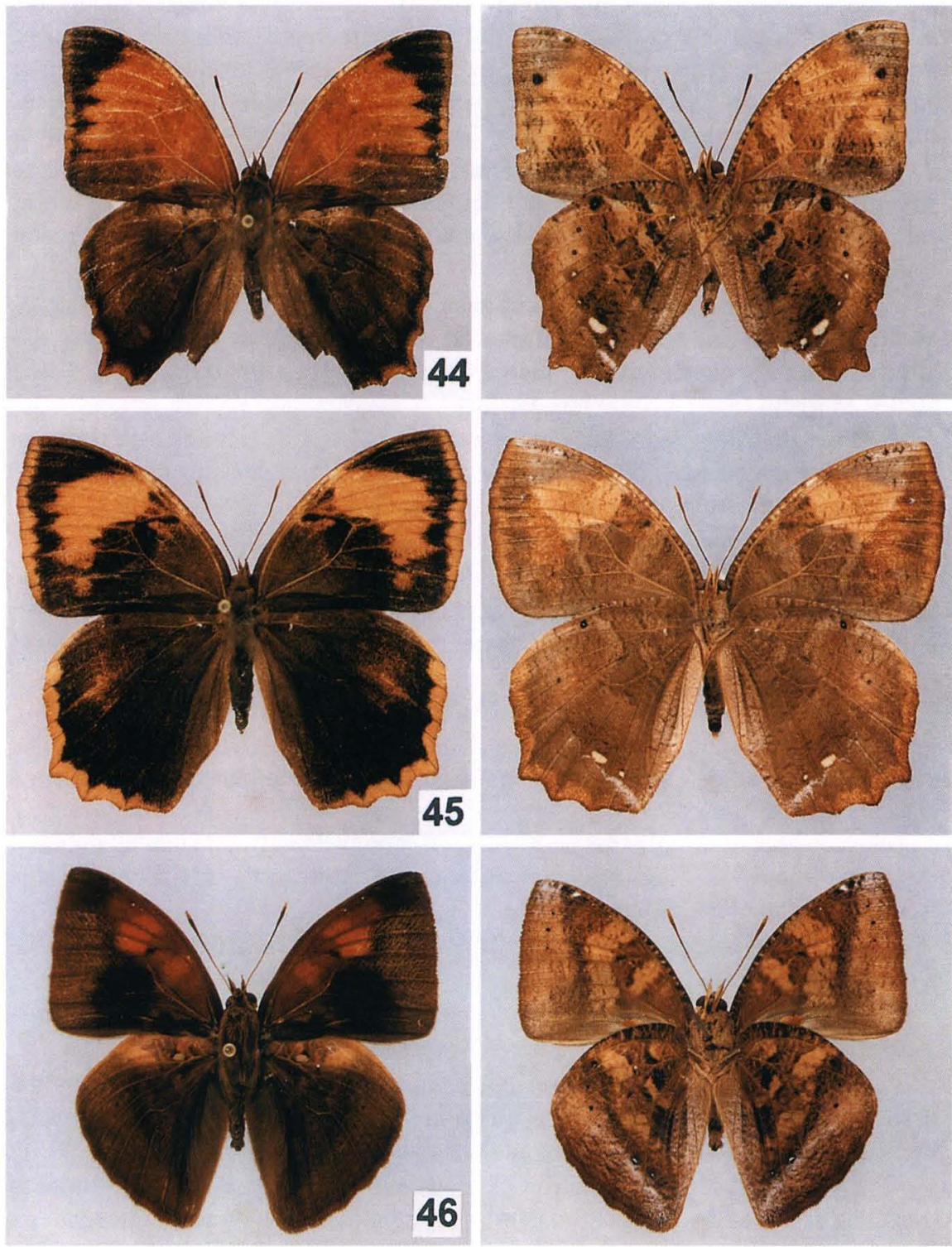

Figs 44-46. (44-45) Narope guilhermei: (44) macho, vistas dorsal e ventral; (45) fêmea, vistas dorsal e ventral; (46) Narope nesope, macho, vistas dorsal e ventral.

Revta bras. Zool. 19 (2): 467 - 569, 2002 
Genitália (Fig. 47A-E). Unco desprovido de espinhos. Subunco retangular, projetado dorsalmente mas não ultrapassando o unco; extremidade distal com numerosos dentes. Valva de bordo distal serrilhado com espinhos proeminentes. Superficie interna e distal deprimida e revestida de inúmeros pequenos espinhos, na parte mediana os espinhos se dispõem sobre uma elevação formando uma carena. Juxta, em vista ventral, em forma de "V" com a margem interna serrilhada.

Fêmea (Figs 45 e 48). Asa anterior: comprimento da margem costal - 33 a $36 \mathrm{~mm}$; margem externa - 21 a $23 \mathrm{~mm}$; largura da asa -22 a $24 \mathrm{~mm}$. Asa posterior: comprimento da margem costal - 24 a $26 \mathrm{~mm}$; margem externa - 24 a $26 \mathrm{~mm}$; maior comprimento da asa -27 a $30 \mathrm{~mm}$.

Face dorsal da asa anterior castanha, pouco mais escuro que nos machos. Mancha amarelo ferrugínea, em forma de meia lua entre as discocelulares e a bifurcação $\mathrm{R}_{4}-\mathrm{R}_{5}$, em alguns exemplares se extende de forma mais estreita até $\mathrm{CuA}_{1}$ ou 2A. Margem externa como nos machos.

Face dorsal da asa posterior castanha, com faixa de $1 \mathrm{~mm}$ de espessura em amarelo ferrugíneo que contorna toda a margem externa. Após as discocelulares uma área com amarelo difuso pode ou não estar presente.

Face ventral das asas anterior e posterior, semelhantes aos machos.

Genitália (Fig. 48). Lamela pós-vaginal como uma placa retangular de extremidades arredondadas, esclerotinizada. A lamela ante-vaginal é formada por uma prega esclerotinizada próxima à lamela pós-vaginal. O duto da bolsa se alarga progressivamente, constituindo a bolsa.

Discussão. Aproxima-se no aspecto geral de $N$. anartes e de $N$. cyllastros. Porém morfologicamente separa-se de $N$. anartes pela ausência de projeções na extremidade distal da valva e dorsais no unco, aspecto do subunco e externamente pelo colorido laranja ferrugíneo das asas anteriores. Difere de $N$. cyllastros pela presença de apenas uma carena na parte distal interna da valva, no tamanho menor da androcônia da face dorsal da asa posterior e pela presença de colorido laranja ferrugíneo e amarelo das asas.

Distribuição espacial (Fig. 54). BRASIL, Santa Catarina: Rio Negrinho e Rio Grande do Sul, Caxias do Sul.

Distribuição temporal. Entre os exemplares estudados pode-se concluir que a espécie voa entre os meses de janeiro e fevereiro.

Etologia. Os exemplares, machos e fêmeas, foram todos coletados no final da tarde, quando a luz do dia está quase ausente. São de voo ágil e se matêm praticamente no mesmo lugar passando de um para outro arbusto.

Planta hospedeira e imaturos. O pouco que se conhece dos hábitos alimentares das espécies do gênero, indicam como sendo Poaceae a planta hospedeira das larvas. Não foram encontrados imaturos, porém no local de coleta dos adultos, segundo informações dos coletores, haviam muitos arbustos de Bambusa sp (Poaceae).

Etimologia. O nome científico é uma homenagem ao coletor Carlos Guilherme Costa Mielke.

Material estudado. Todo o material relacionado no item Material tipo. 


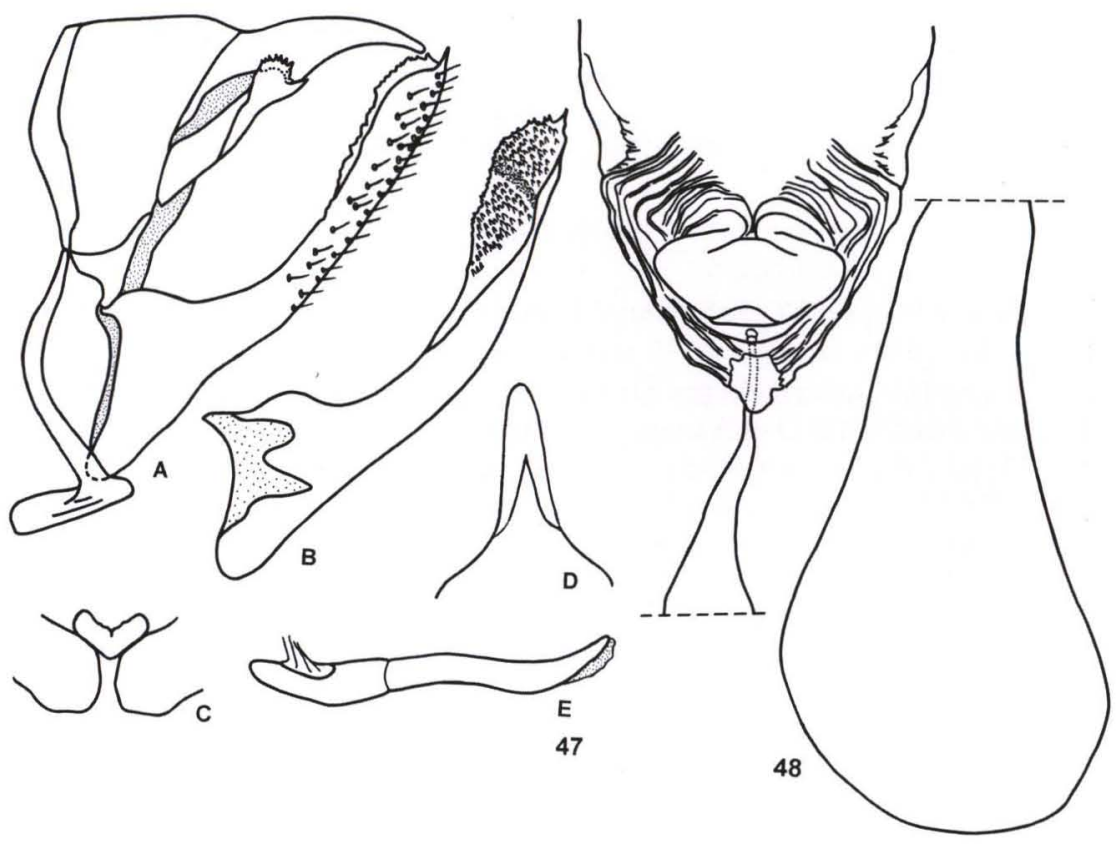

Figs 47-48. Narope guilhermei. (47) Genitália masculina: (A) vista lateral, (B) valva, vista lateral interna, (C) juxta, vista ventral, (D) tegume/unco, vista dorsal, (E) edeago, vista lateral, (48) genitália feminina.

\section{Narope panniculus Stichel, 1904}

Figs $49,50,52-54$

Narope panniculus Stichel, 1904. Ins.- Börse 21: 6; 1 macho, Paraguai [Nueva Germania], coleção Stichel e 3 machos, Rio Yuntas [recte Juntas], Bolívia, 1000m, coleção Staudinger [Museum für Naturkunde der Humboldt Universität, Berlim].- Stichel, 1904, in Wytsman. Gen. Ins. 20, p. 15, pl. 4, fig. 2 (macho d, v); cat., dg.-Stichel, 1909. Tierreich 25, p. 41, 49; cat., sist., dg.-Fruhstorfer, 1910. Ent. Zeit. 24: 194; sist., dg.- Fruhstorfer, 1912, in Seitz. Gross-Schmett. Erde 5, p. 330; sist., dg.- Stichel, 1916. Neue Beitr. syst. Insektenk. 1: 8; sist., dg.- Stichel, 1932. Lep. Cat. 51, p. 16; cat.- D'Abrera, 1987. Butt. Neotrop. Reg. 3, p. 392, figs (macho d, fêmea v); sist., dg.Robbins et al., 1996, in Wilson \& Sandoval. Manu, p. 229; dg.

Narope panniculus piccatus Stichel, 1916. Neue Beitr. syst. Insektenk. 1: 8; tipos: 3 machos, Rio Yuntas [recte Juntas], Bolívia; Mus. Berol.- Stichel, 1932. Lep. Cat. 51, p. 17; cat., dg.- Lamas, 1981. Rev. Soc. Mex. Lep. 6: 30; dg.- D’Abrera, 1987. Butt. Neotrop. Reg. 3, p. 392; sist., dg.; syn. $\mathbf{n}$.

Narope panniculus panniculus; Stichel, 1932. Lep. Cat. 51, p. 16; cat., dg.-Mielke \& Casagrande, 1998 Revta bras. Zool. 14: 975; dg.

Narope paniculus [sic]; Hayward, 1951. Acta zool. lill. 9: 219; cat., dg.- Hayward, 1973. Op. lill. 23: 241 ; cat.; dg.

Histórico. STICHEL (1904) descreve a espécie com base em 1 macho do Paraguai, na coleção Stichel, outros 3 do Rio Yuntas, Bolívia, da coleção Staudinger. STICHEL (1916) define que os 3 exemplares machos do Rio Yuntas, Bolívia 
constituem uma outra subespécie, Narope panniculus piccata. Na mesma publicação inclui para N.panniculus panniculus uma fêmea de Itaituba, Pará, também da coleção Staudinger. Esta fêmea, hoje na Coleção do "The Natural History Museum" é uma fêmea de Aponarope sutor e não de $N$. panniculus panniculus, como supunha Stichel.

O estudo dos lectótipos, comentados a seguir, mostrou que $N$. panniculus piccatus é um novo sinônimo.

Material tipo. No "The Natural History Museum", Londres, Inglaterra, dois machos dos quatro síntipos de $N$. panniculus, foram encontrados. O exemplar de Nueva Germânia, designado por Stichel, 1916 (meinem Original), é aqui interpretado como LECTÓTIPO de Narope panniculus Stichel, com as seguintes etiquetas: /Type/ Typus/ Narope panniculus Stich./ Paraguay Nuev. Germania e.c. H.Stichel/ LECTOTYPE/ Narope panniculus Stichel, 1904, Lectotype, designated by Stichel, 1916, M. M. Casagrande det. 2002/. O exemplar, no "Zoologisches Museum der Humboldt Universität" também síntipo de $N$. panniculus, mais tarde incluido na série dos 3 síntipos de $N$. panniculus piccatus é aqui designado como LECTÓTIPO de Narope panniculus piccatus Stichel, 1916, com o objetivo de garantir a adequada identificação do táxon, com as seguintes etiquetas: /Typus/ BOLÍVIA $1000 \mathrm{~m}$ Rio Juntas Garlepp/ Narope panniculus Stichel/ LECTOTYPE/ Narope panniculus piccatus Stichel, 1916, Lectotype, M. M. Casagrande det. 2002/.

Diagnose. Face dorsal das asas anterior e posterior castanha. Na face dorsal da asa anterior mancha arredondada, de cor preta, ocupando o espaço entre a base das cubitais até a margem interna.

Descrição. Macho (Figs 49-52). Asa anterior: comprimento da margem costal - 30 a $39 \mathrm{~mm}$; margem externa - 20 a $27 \mathrm{~mm}$; largura da asa - 21 a $26 \mathrm{~mm}$. Asa posterior: comprimento da margem costal - 21 a 26; margem externa - 22 a 27 $\mathrm{mm}$; maior comprimento da asa -24 a $27 \mathrm{~mm}$.

Cabeça e apêndices, tórax e abdome castanho.

Face dorsal das asas anterior e posterior castanha. Na asa anterior mancha arredondada, de cor preta, ocupando o espaço entre a base das cubitais até a margem interna.

Asa posterior, com androcônia oval, de tamanho médio, creme, pouco além da bifurcação de Rs-M 1 , sobre Rs. Nenhuma das veias da asa posterior se projeta, conferindo à margem da asa um aspecto completamente arredondado.

$\mathrm{Na}$ face ventral de ambas as asas reflexo metálico prata. $\mathrm{Na}$ asa anterior quatro faixas mais escuras; as três proximais: basal, pós basal e mediana, desde a margem costal até $\mathrm{CuA}_{2}$ e a quarta, com início no espaço $\mathrm{M}_{1}-\mathrm{M}_{2}$ até $\mathrm{CuA} \mathrm{A}_{2}$, juntamente com ponto preto; faixa diagonal do ápice até o meio de $2 \mathrm{~A}$, ausente. Da margem costal até $\mathrm{a} S \mathrm{Sc}+\mathrm{R}_{1}$, pequenas linhas formadas por escamas brancas, perpendiculares à margem costal e intercaladas por áreas escuras. Sobre a metade proximal de $2 \mathrm{~A}$, androcônia oval, creme, pouco maior que aquela da face dorsal da asa posterior.

$\mathrm{Na}$ asa posterior a metade proximal mais clara e a distal mais escura, e com efeito metalizado prata mais intenso. Em alguns exemplares, pode estar presente uma linha de pontos submarginais, formados por escamas brancas, acompanhando o contorno arredondado da asa (Fig. 49). 

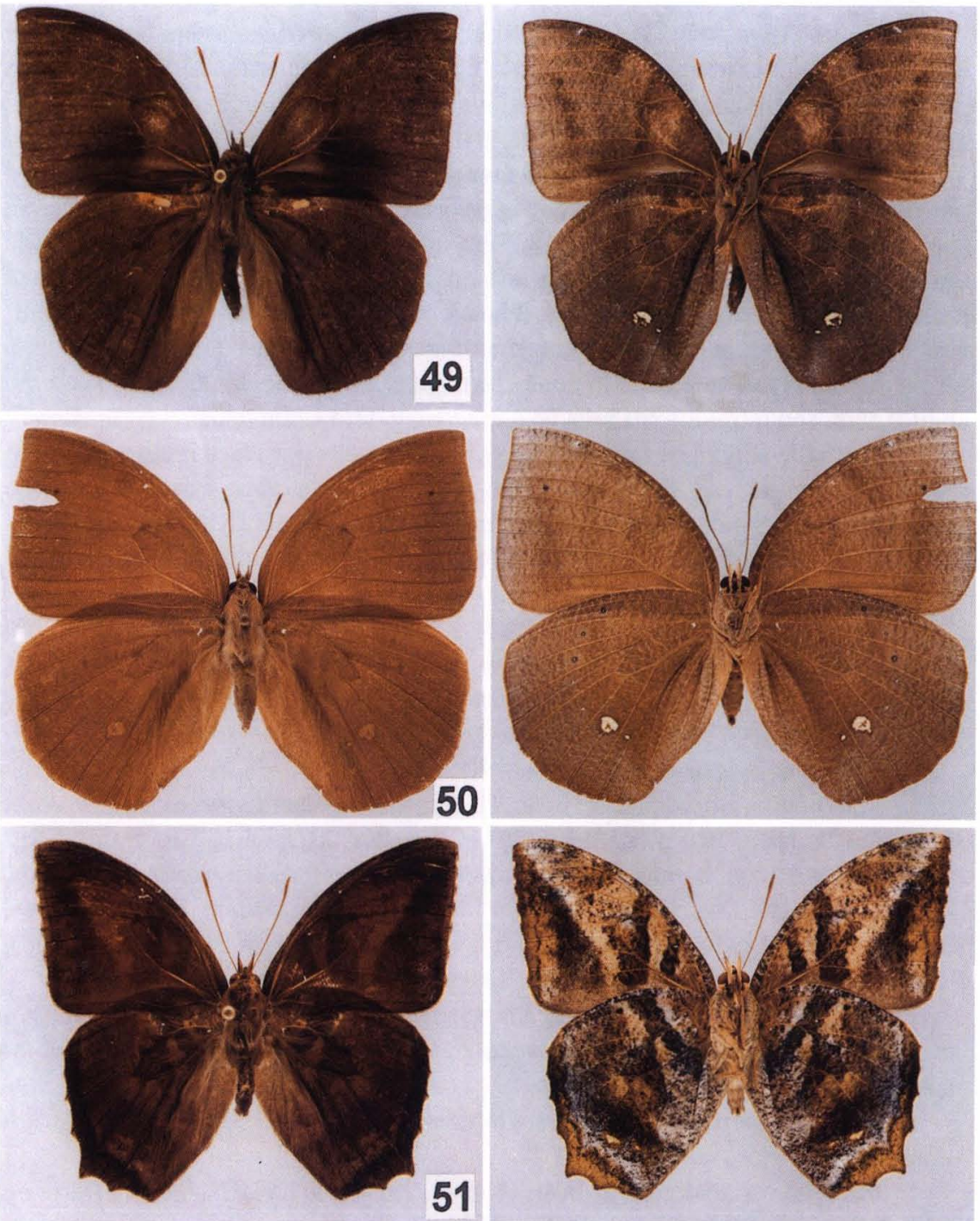

Figs 49-51. (49-50) Narope panniculus: (49) macho, vistas dorsal e ventral; (50) fêmea, vistas dorsal e ventral; (51) Narope denticulatus, macho, vistas dorsal e ventral.

Genitália (Fig. 52A-E). Unco curvo e sem espinhos ou projeções. Subunco alongado e estreito, projetado para além da margem superior do unco. Valva com extremidade em ponta suave e projetada para além do unco, faces externa e interna com numerosas cerdas, sem espinhos. Juxta, em vista ventral, em forma de $\mathrm{V}$, com profunda fenda na região mediana distal. 
Fêmea (Figs 50 e 53). Asa anterior: comprimento da margem costal - 31 a $33 \mathrm{~mm}$; margem externa - 22 a $24 \mathrm{~mm}$; maior largura da asa -23 a $25 \mathrm{~mm}$. Asa posterior: comprimento da margem costal -24 a $26 \mathrm{~mm}$; margem externa - 24 a 25 $\mathrm{mm}$; maior comprimento da asa -25 a $26 \mathrm{~mm}$.

Asas anterior e posterior com a face dorsal em castanho claro, sem faixas ou manchas. Na face ventral, a cor ainda mais clara que da face dorsal, apenas a faixa submarginal, que como nos machos, tem início no espaço entre $\mathrm{M}_{1}-\mathrm{M}_{2}$, onde também está presente uma mancha arredondada e escura. $\mathrm{O}$ aspecto prata metálico permanece menos intenso que nos machos. Como nestes, alguns exemplares femininos também podem apresentar manchas claras submarginais que acompanham a forma da asa. A asa anterior têm contorno distinto do macho, tanto o ápice como o ângulo anal, são retraídos em relação à margem externa, convexa.

Genitália (Fig. 53). Lamelá pós-vaginal formada por placa retangular quase totalmente dividida ao meio, formando duas placas laterais, estreitas na parte mediana e convergindo nas laterais para a parte dorsal. Lamela ante-vaginal pequena, também retangular e pouco esclerotinizada. Duto da bolsa e bolsa de igual tamanho, esta alongada.

Discussão. Distingue-se de todas as outras espécies do gênero pelo contorno arredondado da asa posterior. A mancha arredondada de escamas escuras na face dorsal da asa anterior também é encontrada em $N$. nesope mas pode facilmente ser distinguida desta por não apresentar ferrugíneo nas asas.

Distribuição espacial (Fig. 54). EQUADOR. PERU, Madre de Dios: Ibéria, Puerto Maldonado, Boca Rio La Torre; San Martin: Jepelacio; Loreto: Rio Ucayali; Junín, Rio Perené. Bolívia, Santa Cruz: Buenavista (Ichilo), Rio Surutu, Rio Japacani. PARAguaI: Sapucay, Yhu, Villarica. ARgentina, Missiones, Entre Rios. BRASIL, Pará: Óbidos; Distrito Federal: Planaltina; Mato Grosso: Buriti, Cáceres, Brasnorte; São Paulo: Teodoro Sampaio (Parque Estadual Morro do Diabo); Paraná: Rio Piquiri, Toledo, Rondon, Tapejara.

Distribuição temporal. Os registros indicam que a espécie ocorre todo o ano.

Etologia. Machos são atraídos para restos de animais (sapos) em decomposição.

Planta hospedeira e imaturos. Desconhecidos, mas acredita-se que devam alimentar-se de Poaceae.

Material estudado. EQUADOR, Oriente, 2 machos (AME). PERU, Madre de Dios: Iberia, 2 machos, 10.IV.1973, (CU); Puerto Maldonado, 250m, 1 fêmea, 21.VIII.1987, L.Miller leg. (AME); Boca Rio La Torre, 300m, 1 macho, 9.XI.1979, Heppner leg., 2 machos, 2.X.1981, Lamas leg., 1 fêmea, 22.X.1985, Lamas leg. (MHNL); San Martín: Jepelacio, 1 macho, (AMNH), 2 machos, (USMN); Loreto, R. Ucayali, 2 machos, 6.II.1928, 9.III.1929, (AMNH); Junín, Rio Perené, 2 machos, (MHNL). BolíviA, Santa Cruz: Buenavista, Ichilo, 400m, 1 macho, III.1955, (AME); 2 machos, IV e V.1915, Steinbach leg. (CMP); 3 machos, (UFPC); Rio Juntas, 1 macho (lectótipo de N. panniculus piccatus) (BMNH) Rio Juntas, 1000 m, 2 machos, 1890, Michael leg. (ZMHB); Rio Surutu, 600 m, 1 macho, II.1915, Steinbach leg., Rio Japacani, 8 machos, (1) II.1914, (2) IX.1914, (3) II.1915, (2) 


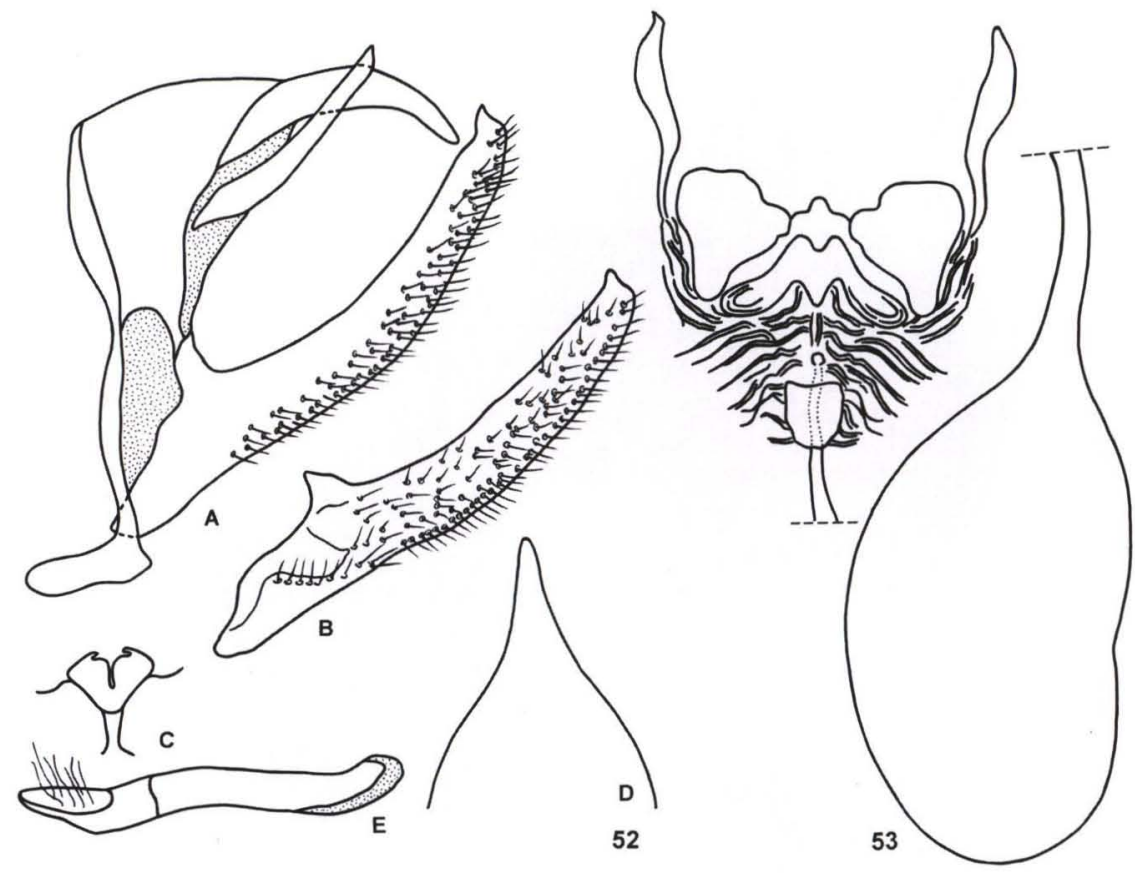

Figs 52-53. Narope panniculus. (52) Genitália masculina: (A) vista lateral, (B) valva, vista lateral interna, (C) juxta, vista ventral, (D) tegume/unco, vista dorsal, (E) edeago, vista lateral, (53) genitália feminina.

III.1915, (CMP). PARAGUAI, 1 macho, (BMNH); Sapucay, 3 machos, 19.XII.1902, 5.VI.1903, 23.XII.1904, 1 macho, (BMNH); Yhu, 4 machos, IX-XII. 96, (BMNH), Villarica, Nueva Germania, 1 macho (lectótipo de N. panniculus) (BMNH), Villarica, Colônia Carlos Pfannl, 1 macho, J. Anders leg.; R. Iguazu, 1 macho, XII.1960, (UFPC). ARGENTINA, Missiones: 1 macho e 1 fêmea, IX, 1927, (BMNH); 2 machos, XII. 1957, (AME); Entre Rios: 2 machos, H.H. Smith leg., (BMNH). BRASIL, Pará: Óbidos, 1 macho, IX.1968, Kesselring leg., (UFPC); Distrito Federal: Planaltina, 1000 m, 1 fêmea, 10.VI.1976, V. Becker leg., (UFPC); Mato Grosso: Buriti, 4 machos, 24.V.1969, 7.VI.1970, 15.VI.1970 e 16.VI.1970, (KB), 1 fêmea, 4.VI. 1971, (OM); Cáceres, 5 machos, 18-19.XI.1984, Buzzi, Mielke, Elias \& Casagrande leg., 2 machos, 1-15.XII.1984, 4 machos, 1-9.II.1985, Elias leg., (UFPC), Brasnorte, 3 machos, 23.VII.1987, Miers leg., (OM); 5 machos, 5-20.VII.1990, 400 m, C.G.Mielke \& Miers leg. (CGCM); São Paulo: Teodoro Sampaio, Parque Estadual Morro do Diabo, 300- 600 m, 9 machos, 22-25.X.1987, Mielke \& Casagrande leg. (OM); 1 macho, 20-23.II.1990, Mielke \& Casagrande leg., (UFPC). Paraná: Rio Piquiri, 1 fêmea, 7.VIII.1940, Mayes leg.; Rondon, 1 macho, 10.III.1959; Tapejara, 1 macho, I. 1953; Toledo, 1 macho, VIII-IX.1959, Mohr leg. (OM). 


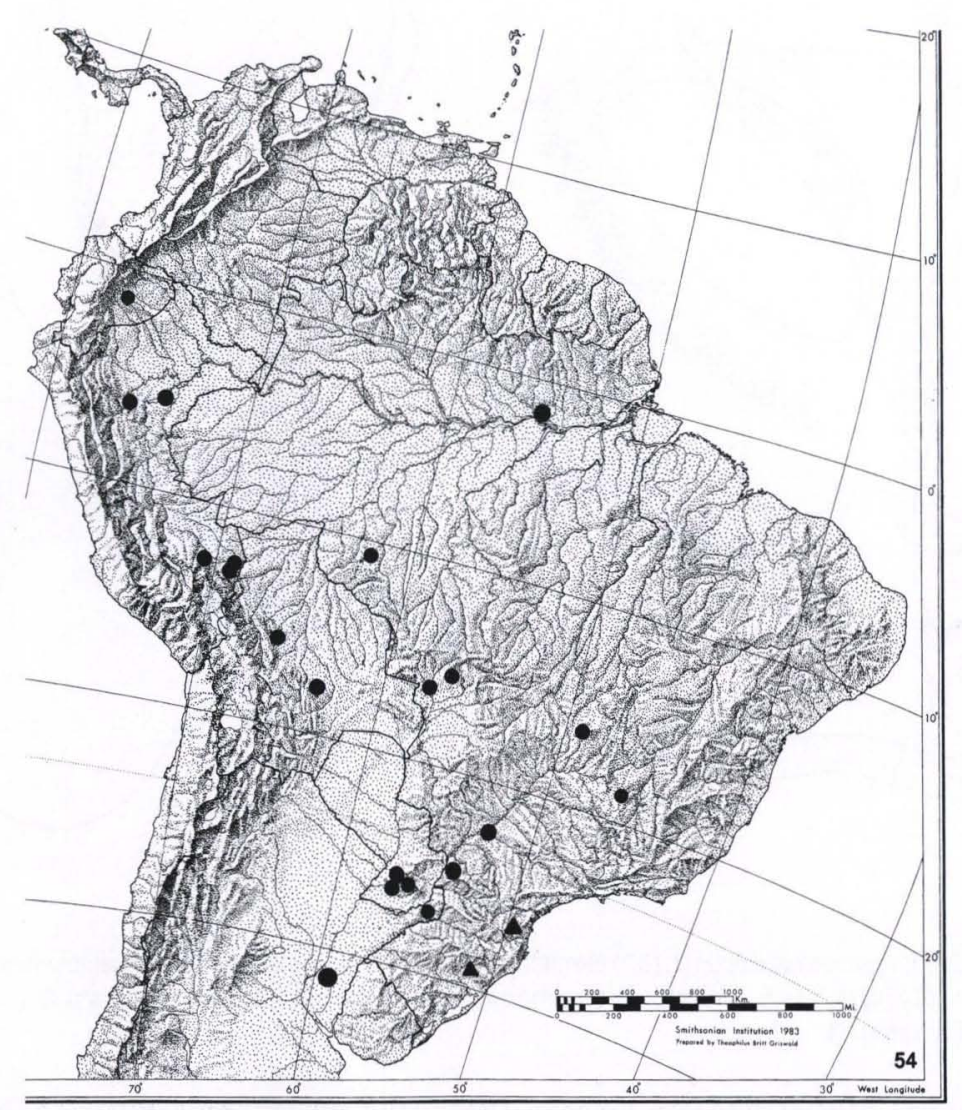

Fig. 54. Distribuição espacial. (•) Narope panniculus, (A) Narope guilhermei.

\section{Narope nesope Hewitson, 1869}

Figs 46,55 e 57

Narope nesope Hewitson, 1869. Equat. Lep., 4 p. 32, index p. [1]; Curaray, Equador, Buckley leg.-Kirby, 1871. Syn. Cat. Diurn. Lep., p. 129; cat.- Stichel, 1904, in Wytsman. Gen. Ins. 20, p. 15; cat., dg.- Stichel, 1909. Tierreich 25, p. 42, 48; cat., sist., dg.- Fruhstorfer, 1912, in Seitz. Gross-Schmett. Erde 5, p. 329; sist., dg.-Stichel, 1932. Lep. Cat. 51, p. 16; cat., dg.- D'Abrera, 1987. Butt. Neotrop. Reg. 3, p. 392, figs (macho d, v); sist., dg.- Robbins et al., 1996, in Wilson \& Sandoval. Manu, p. 229; dg.

Narope pusilla Röber, 1929. Intern. ent. Ztschr. 23: 325; 1 macho [holótipo], Buenavista, 75 km NO Santa Cruz, Bolívia, coleção Kotzsch.-Stichel, 1932. Lep. Cat. 51, p. 17; cat., dg. syn. n. Naropina pusilla; Röber, 1929. Intern. ent. Ztschr. 23: 326.

Histórico. Espécie descrita de Curaray, Equador, à margem do Rio Curaray, um dos afluentes da margem direita do Rio Napo. A comparação do lectótipo de $N$. nesope, a seguir designado, com a descrição de $N$. pusilla mostrou que esse é um novo sinônimo. 
Material tipo. A descrição da espécie está baseada em número não definido de exemplares. Um síntipo macho foi encontrado no "The Natural History Museum", Londres, Inglaterra, é aqui designado LECTÓTIPO, com o objetivo de garantir a adequada identificação da espécie, com as seguintes etiquetas: /Type/ Equal nesopel Ecuador, Hewitson Coll. 79 - 69, Narope nesope Hew./ B.M. Type No Rh 6119 Narope nesope or Hew./ LECTOTYPE/ Narope nesope Hewitson, 1869, Lectotype, M. M. Casagrande det. 2002/. O holótipo de N. pusilla, segundo Dr. Gerardo Lamas está depositado no "Zoologisches Museum", Copenhague, Dinamarca.

Diagnose. Asas anterior e posterior castanho. Na anterior, ferrugíneo em 3/4 basais da margem costal e parte adjacente a célula discal; acompanhando externamente na base de m-cu até a margem interna, mancha arredondada de escamas pretas. Algumas escamas pretas difusas sobre $\mathrm{M}_{2}-\mathrm{M}_{3}$.

Descrição. Macho (Figs 46 e 55). Asa anterior: comprimento da margem costal - 25 a $28 \mathrm{~mm}$; margem externa - 20 a $28 \mathrm{~mm}$; largura da asa - 18 a $21 \mathrm{~mm}$. Asa posterior: comprimento da margem costal - 16 a $20 \mathrm{~mm}$; margem externa - 21 a $23 \mathrm{~mm}$; maior comprimento da asa -22 a $24 \mathrm{~mm}$.

Cabeça e apêndices, e tórax castanho ferrugíneo. Abdome castanho.

Face dorsal das asas anterior e posterior castanho e sobre a margem externa discreta linha ferrugínea com aproximadamente $1 \mathrm{~mm}$ de largura. $\mathrm{Na}$ asa anterior, ferrugíneo em 3/4 basais da margem costal e parte adjacente da célula discal, as escamas desta cor, não ocupam espaços abaixo da célula e nem abaixo de $\mathrm{M}_{3}$; acompanhando externamente à célula, na base de $\mathrm{m}$-cu, até a margem interna, mancha arredondada de escamas pretas. Algumas escamas pretas difusas sobre $\mathrm{M}_{2}-\mathrm{M}_{3}$. Na asa posterior, androcônia, oval de tamanho médio, creme, pouco além da bifurcação Rs-M1, sobre Rs. Maior projeção da asa em 2A.

Face ventral das asas anterior e posterior com predominância de escamas castanho amarelado. Linhas e pontos mais escuros em tons de castanho avermelhado. $\mathrm{Na}$ asa anterior, uma faixa obliqua, pouco antes do ápice até o meio da margem interna. Faixa na metade da margem costal, ao longo de toda a base de $\mathrm{M}_{1}-\mathrm{M}_{2}$, $\mathrm{M}_{2}-\mathrm{M}_{3}$, quebrando abruptamente em m-cu, e acompanhando paralelamente a faixa distal até a margem interna; pequenos pontos brancos entre $\mathrm{R}_{3}-\mathrm{R}_{4}$ próximos ao ápice; a faixa diagonal do ápice até o meio de $2 \mathrm{~A}$ está ausente; sobre a metade proximal de $2 \mathrm{~A}$, androcônia com escamas ferrugíneas, pouco maior que aquela da face dorsal da asa posterior.

$\mathrm{Na}$ asa posterior, metade proximal da célula discal com escamas castanho escuro. Pouco além do meio da margem interna, faixa castanho escuro avermelhada antecedida por ponto escuro projeta-se até a margem anal pouco antes do ângulo anal. De $\mathrm{M}_{2}$ até o ângulo anal, esta faixa é acompanhada, externamente, por outra faixa de cor branca. Além desta, até a margem externa o aspecto é violeta metálico. Dois pontos negros com pupilas brancas antecedem essa faixa e estão sobre faixa escura, entre $\mathrm{CuA}_{1}-\mathrm{CuA}_{2}$ e $\mathrm{CuA}_{2}-2 \mathrm{~A}$, respectivamente.

Genitália (Fig. 55A-E). Unco projetado distalmente, quase reto na borda ventral. Subunco retangular e afilado na extremidade distal, sem espinhos. Valva 

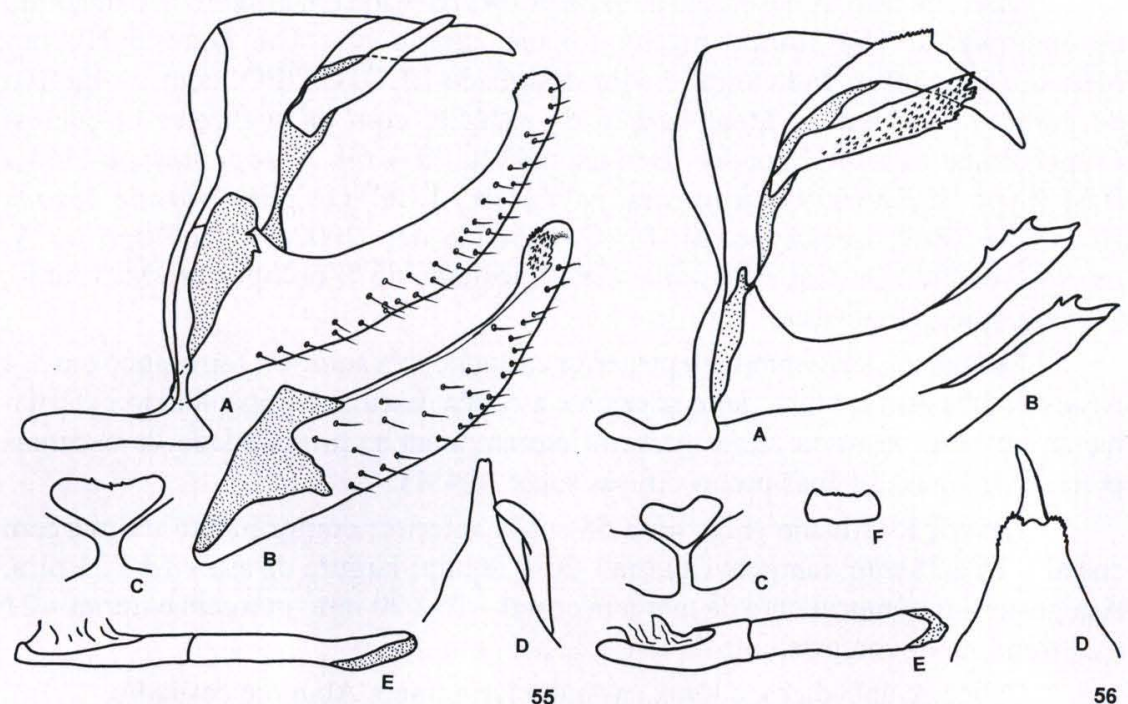

55

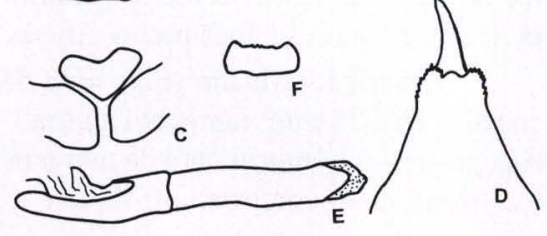

56

Figs 55-56. Genitália masculina: (A) vista lateral, (B) valva, vista lateral interna, (C) juxta, vista ventral, $(D)$ tegume/unco, vista dorsal, $(E)$ edeago, vista lateral, $(F)$ gnato, vista ventral; (55) Narope nesope; (56) Narope denticulatus.

projetada para além da extremidade distal do unco; distalmente o bordo dorsal em vista interna com área de fortes projeções como espinhos. Juxta, em vista ventral, com forma de um triangulo invertido, com suave depressão na porção distal.

Fêmea. Desconhecida.

Discussão. Entre as espécies do gênero, é a de menor evergadura alar. Como em $N$. panniculus, apresenta uma mancha preta de aspecto arredondado no centro da metade inferior da asa anterior. É facilmente distinta desta, pela coloração ferrugínea na asa anterior.

Distribuição espacial (Fig. 57). EQUADOR, Curaray. PERU, Madre de Dios: Pakitza, Tambopata, Salvacion; Puno: Chaquimayo, Yahuarmayo, Carabaya. BoLíviA, Santa Cruz: Buenavista (Ichilo, Rio Yapacani). BRASIL, Acre: Xapuri; Rondônia: Jarú.

Distribuição temporal. Entre os exemplares estudados das diferentes coleções e do material coletado encontram-se registros de adultos voando entre os meses de fevereiro, março, junho-agosto e outubro.

Etologia. Machos foram coletados em armadilhas com iscas de frutas em decomposição.

Planta hospedeira e imaturos. Desconhecidos, mas acredita-se que devam alimentar-se de Poaceae. 


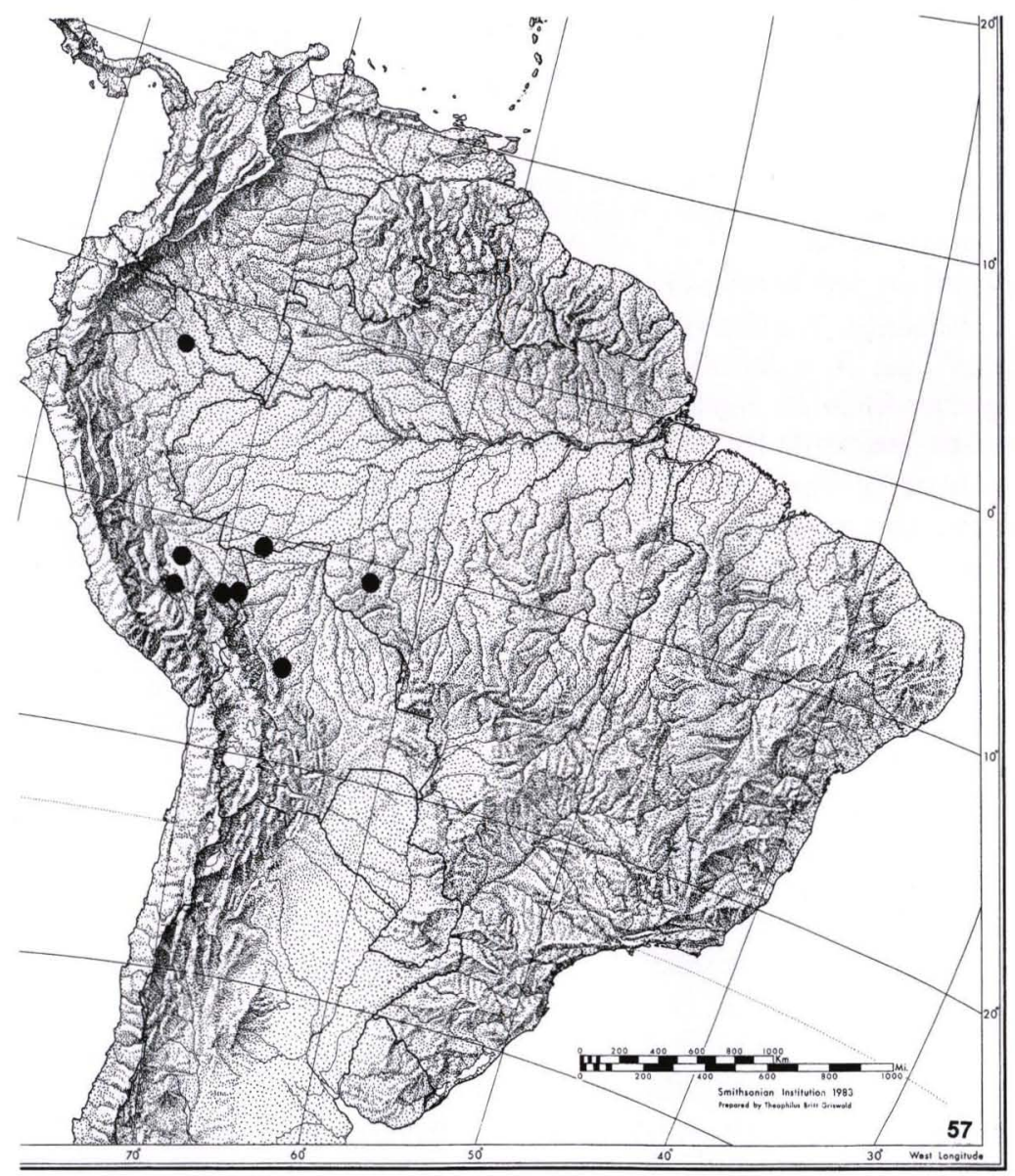

Fig. 57. Narope nesope, distribuição espacial.

Material estudado. EQUADOR, 3 machos (CU); Curaray, 1 macho (lectótipo) (BMNH); PERU, Madre de Dios: Salvacion, 400 m, 1 macho, III. 1990, M. Büche leg. (OM); Pakitza, Parque Nacional Manu, 340 m, 2 machos, 15 e 19.X.1991, Casagrande leg. (UFPC); Tambopata Reserve, 300 m, 5 machos, 26, 27 e 29.X.1991, Casagrande leg. (UFPC); Puno: Chaquimayo, 2500-3000ft, 1 macho, H.C. Watkins leg. (BMNH); Yahuarmayo, 1200ft, 1 macho, Febr. March. 1912, H.C. Watkins leg. (BMNH); Carabaya, R. Huacamayo, 2000 ft, 1 macho, G. Ockenden leg. (BMNH). BolíviA, Santa Cruz: Buenavista, 1 macho (AME); Buenavista, Ichilo, 400 m, 1 macho (UFPC); R. Yapacani, 1 macho, VIII.1913, Steinbacher leg. (CMP). BRASIL, Acre: Xapuri, 2 machos, 1934, F. Oiticica F. leg. (UFPC); Rondônia: Jarú, 1 macho, 5.VIII.1975, Brown leg. (KB); Candeias do Jamari, Banho do Rio Preto, 1 macho, 1-15.VII.1996, O.- C.G. Mielke \& Miers leg. (OM). 


\title{
Narope denticulatus Talbot, 1928, stat. $\mathbf{n}$.
}

\author{
Figs 51,56 e 58
}

Narope cyllastros denticulatus Talbot, 1928. Bull. Hill Mus. 2: 200, 221, pl. 8, Fig. 13 (macho d); 1 macho holótipo, 6-VI-1927, Tombador, 16 mi S. Diamantino, Mato Grosso, Brasil, Collenette leg.; Hill Museum [transferido para o BM(NH)].- D'Abrera, 1987. Butt. Neotrop. Reg. 3, p. 390, fig. (macho v); sist., dg.

Narope cyllastros denticulata [sic]; Stichel, 1932. Lep. Cat. 51: 15; Cat., dg.

Histórico. TALBOT (1928) ao descrever $N$. cyllastros denticulatus faz comparações com $N$. cyllastros, salientando o crenulado da margem das asas na subespécie. Além do holótipo, inclui também dois machos [parátipos] do Mato Grosso na coleção do Hill Museum [transferidos para o BMNH].

Material Tipo. HOLÓTIPO no "The Natural History Museum" Londres, Inglaterra, com as seguintes etiquetas: / Type HT / 39. 27 Tombador, 16 miles S. of Diamantino $1500 \mathrm{ft} 4$ - 6. VI. 27 Matto Grosso C. L. Collenette/ Narope cyllastros denticulatus macho H.T. Talb. 1928/.

Diagnose. Asa anterior castanho ferrugíneo e a posterior, parcialmente castanho avermelhado. Margem externa de ambas as asas denteada, acompanhadas por franja de escamas creme. Face ventral amarelo pardo, com faixas em castanho escuro e branco.

Descrição. Macho (Figs 51 e 56). Asa anterior: comprimento da margem costal - 27 a $30 \mathrm{~mm}$; margem externa - 20 a $22 \mathrm{~mm}$; largura da asa -18 a $20 \mathrm{~mm}$. Asa posterior: comprimento da margem costal -19 a $21 \mathrm{~mm}$; margem externa - 21 a $23 \mathrm{~mm}$; maior comprimento da asa -23 a $25 \mathrm{~mm}$.

Cabeça, tórax e abdome castanho. Antenas com flagelômeros basais castanho e os apicais ferrugíneo.

Face dorsal da asa anterior com a parte central castanho ferrugíneo e as extremidades junto às margens costal e externa castanho escuro avermelhado, franjas creme. Asa posterior com área adjacente à célula discal castanho ferrugíneo e o restante castanho escuro avermelhado; com suave linha submarginal em preto, com início em $\mathrm{Sc}+\mathrm{R}_{1}$, acompanha a margem externa até $2 \mathrm{~A}$; androcônia oval de tamanho médio, creme, pouco além da bifurcação de Rs-M1, sobre Rs; margem externa fortemente crenulada (Fig. 51) com projeção acentuada, acompanhada pela veia $\mathrm{CuA}_{1}$.

Face ventral da asa anterior, de cor predominante amarelo pardo; do ápice até o meio de $2 \mathrm{~A}$, faixa diagonal, de aproximadamente $2 \mathrm{~mm}$ de largura, com escamas brancas mescladas e, outras duas, escuras, a basal desde a margem costal, passando pela dcs e base de $\mathrm{CuA}_{2}$ terminando sobre $2 \mathrm{~A}$, a terceira pós-basal; sobre a metade proximal de $2 \mathrm{~A}$, androcônia de escamas creme, do mesmo tamanho que aquela da face dorsal da asa posterior.

Face ventral da asa posterior com a faixa basal formada por escamas escuras; a pós-basal com início na base de $\mathrm{M}_{1}$, une-se com a basal formando um "Y" invertido; linha submarginal, crenulada e escura; o espaço compreendido entre essa linha e a margem da asa amarelo palha; proximal à linha submarginal uma área de escamas brancas com reflexo prata, antecedida por faixa mais larga de escamas escuras. Todo o restante da asa com pequenos aglomerados de escamas escuras. 


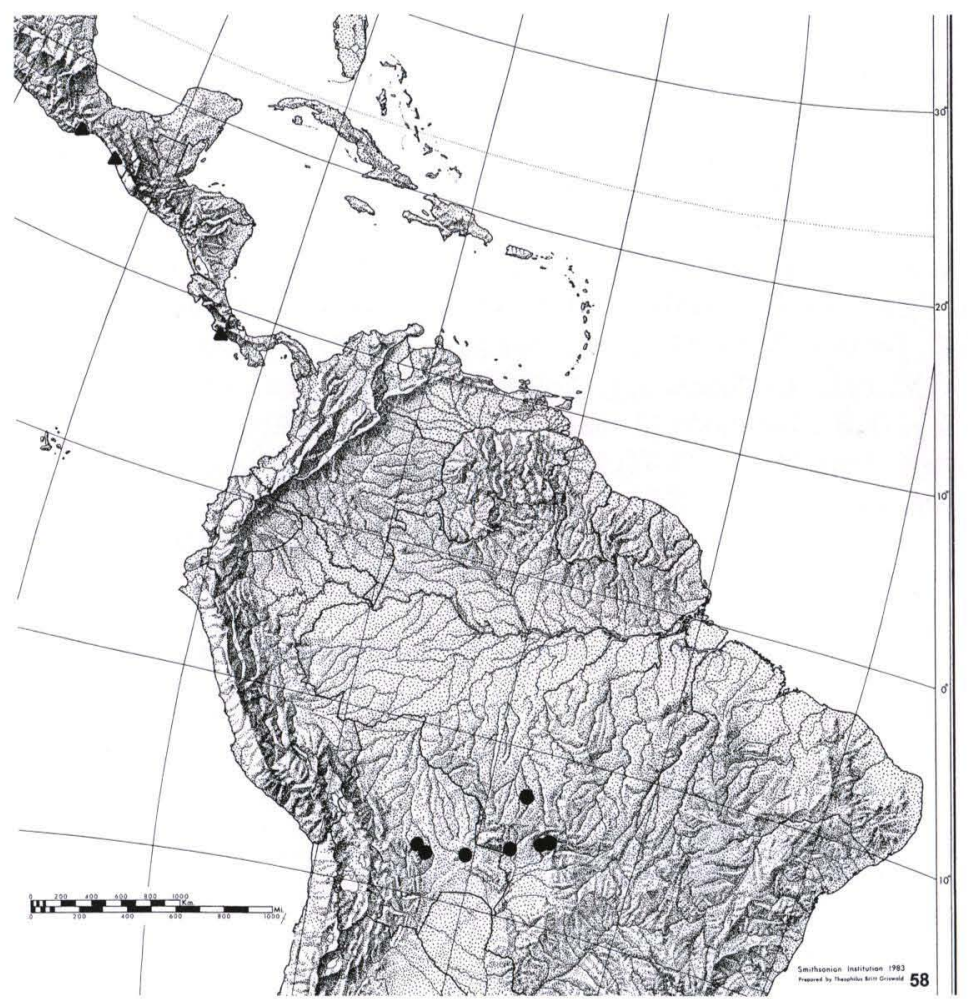

Fig. 58. Distribuição espacial. (•) Narope denticulatus, (A) Narope testacea.

Genitália (Fig. 56A-E). Unco curvo, com projeção bilobada e crenulada na face dorsal. Subunco retangular, com extremidade distal denteada; porção lateral revestida de numerosos espinhos. Valva projetada além da extremidade distal do unco com três a quatro projeções na porção dorsal e distal. Juxta, em vista ventral, com forma de U. Gnato em forma de placa retangular, com suave denteado na porção distal.

Fêmea. Desconhecida.

Discussão. O padrão de coloração da face ventral das asas, a margem externa da asa denteada e com escamas brancas, as características do subunco e da valva, assim como a distribuição geográfica de Narope denticulatus caracterizam a espécie de forma tal a separá-la de $N$. cyllastros com a qual pode ser confundida. Consequentemente $N$. denticulatus é um stat. $\mathbf{n}$.

Distribuição espacial (Fig. 58). BolíviA, Santa Cruz: Chiquitos, Buenavista. Brasil, Mato Grosso: Diamantino (Tombador), Buriti, Brasnorte, Cáceres, Chapada dos Guimarães.

Distribuição temporal. Entre o material estudado encontrou-se adultos coletados em fevereiro, abril, junho, julho, setembro e novembro, assim sendo pode-se supor que deva voar o ano todo. 
Etologia. TALBOT (1928) ao descrever a subespécie, cita que a mesma foi coletada em uma área de sol dentro da floresta. Provavelmente estava pousada sobre restos de frutas em decomposição ou mancha de urina de algum animal, pois das espécies de hábitos conhecidos só são ativas no crepúsculo.

Planta hospedeira e imaturos. Desconhecidos, mas acredita-se que devam alimentar-se de Poaceae.

Material estudado. Bolívia, Santa Cruz: Chiquitos, 1 macho; 1 macho, 1905/6, Steinbach leg. (BMNH), Buenavista, 750 m, 4 machos, Steinbach leg. (BMNH). BRASIL, Mato Grosso: 3 machos (UFPC), Diamantino, Tombador, 1 macho, 6.VI.1927, Collenette leg. (holótipo) (BMNH), Buriti, 1 macho, 14.II.1966, Brown leg. (KB). Brasnorte, 1 macho, 21.VII.1987, Miers leg. (OM); Brasnorte, Faz. Paraná, 3 machos, 5-20.VII.1990, Mielke leg. (OM). Cáceres, 13-19.XI.1984, 28 machos, Buzzi, Mielke, Elias \& Casagrande leg. (UFPC), 5 machos, 1-9.X.1985, Elias leg. (UFPC), Chapada dos Guimarães, 1 macho, abril, H.H.Smith leg. (BMNH); Minas Gerais: 1 macho, Garbe leg. (MZUSP).

\section{Narope testacea Godman \& Salvin, 1878, stat. rev. Figs 58-60, 63-64}

Narope testacea Godman \& Salvin, 1878. Ann. \& Mag. Nat. Hist. (5)2: 259; macho, fêmea, Chiriqui,

[Panamá], Ribbe leg.; coleção Staudinger.- Godman \& Salvin, 1881, in Godman \& Salvin. Biol.

Centr.-Amer., Lep. Rhop. 1, p. 139, pl. 15, figs 4-6 (macho d, v, fêmea d); sist., dg.- Staudinger,

1887, in Staudinger \& Schatz, Exot. Schmett. 1, p. 218; sist.- R. Maza R., 1987. Marip.

Mexicanas, p. 96, pl. 27, fig. 6 (macho d); dg.- D'Abrera, 1987. Butt. Neotrop. Reg. 3, p. 392,

fig. (macho v, como albopunctum); sist., dg.

Narope cyllastros testacea; Stichel, 1904. Ins.- Börse 21: 197; sist., dg.- Stichel, 1904, in Wytsman.

Gen. Ins. 20, p. 15; cat., dg.- Stichel, 1909. Tierreich 25, p. 44; cat., sist., dg.-Fruhstorfer, 1912,

in Seitz, Gross-Schmett. Erde, 5, p. 328; sist., dg.- Stichel, 1932. Cat. Lep. 51: 15; cat., dg.- R.

Maza E. \& J. Maza. 1993. Marip. Chiapas, p. 183; dg.

Histórico. A descrição original está baseada em ambos os sexos, coletados por Ribbe no Chiriqui, Panamá. STICHEL (1904) a menciona como subespécie de N. cyllastros. As citações de DEVRIES (1987) e PENZ et al. (2000) referem-se à $N$. minor sp. n., descrita a seguir.

Material tipo. No "Zoologisches Museum der Humboldt Universität", Berlim, Alemanha, estão os dois síntipos utilizados na descrição original. O macho, aqui designado como LECTÓTIPO, com o objetivo de garantir a adequada identificação da espécie, com as seguintes etiquetas: / Narope testacea G \& S /299/ Origin./ Chiriqui Ribbe/LECTOTYPE/ Narope testacea Godman \& Salvin, 1878, Lectotype, M. M. Casagrande det. 2002/ e a fêmea, designada como PARALECTÓTIPO com as seguintes etiquetas: /Origin./Chiriqui Ribbe/ PARALECTOTYPE/ Narope testacea Godman \& Salvin, 1878, Paralectotype, M.M. Casagrande det. 2002/.

Diagnose. Face dorsal das asas anterior e posterior castanho claro ferrugíneo. Linha marginal denteada e enegrecida, contornando toda a margem. Genitália masculina de unco com projeções laterais denteadas.

Figs 59-62. (59-60) Narope testacea: (59) macho, vistas dorsal e ventral; (60) fêmea, vistas dorsal e ventral; (61-62) Narope minorsp. n.: (61) macho, holótipo, vistas dorsal e ventral; (62) fêmea, alótipo, vistas dorsal e ventral. 

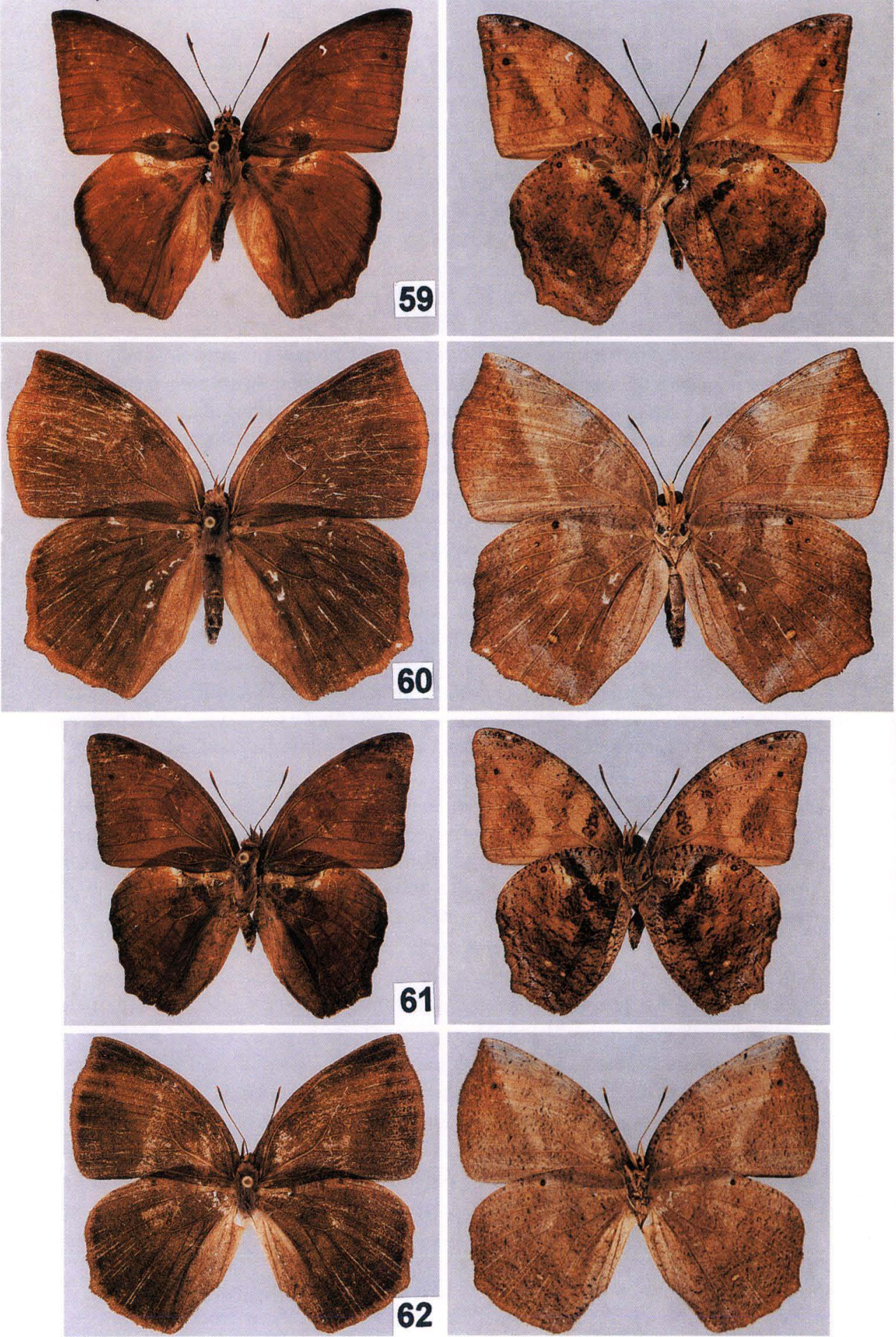

Revta bras. Zool. 19 (2): 467 - 569, 2002 
Descrição. Macho (Figs 59 e 63). Asa anterior: comprimento da margem costal - 30 a $32 \mathrm{~mm}$; margem externa 21 a $22 \mathrm{~mm}$; largura da asa - 20 a $21 \mathrm{~mm}$. Asa posterior comprimento da margem costal -20 a $22 \mathrm{~mm}$; margem externa - 22 a $23 \mathrm{~mm}$; maior comprimento da asa -23 a $25 \mathrm{~mm}$.

Cabeça e apêndices, tórax e abdome amarelo ferrugíneo.

Face dorsal das asas anterior e posterior castanho amarelado ferrugíneo. $\mathrm{Na}$ asa anterior, margem costal com escamas amarelo palha com aproximadamente $1 \mathrm{~mm}$ de largura; entre $\mathrm{R}_{2}$ e $\mathrm{R}_{5}$ com escamas pretas; linha marginal sinuosa e escura; ponto escuro no terço distal entre $\mathrm{M}_{1}-\mathrm{M}_{2}$. Na asa posterior, androcônia oval, de tamanho médio, creme, pouco além da bifurcação Rs-M 1 , sobre Rs.

$\mathrm{Na}$ face ventral da asa anterior, a cor predominante é amarelo palha, com inúmeros pequenos aglomerados de escamas pretas. Do ápice da asa até o meio de $2 \mathrm{~A}$, faixa diagonal, com aproximadamente $2 \mathrm{~mm}$ de largura e escamas mais claras, divide a asa em duas áreas; a distal mais escura e a proximal mais clara. Outras duas faixas, não tão evidentes, sendo uma delas, a basal, desde a margem costal, passando pela dcs, parte interna da célula discal até $2 \mathrm{~A}$; a outra pós-basal, do meio da margem costal, sobre as discocelulares até à base de $2 \mathrm{~A}$; sobre a metade proximal de $2 \mathrm{~A}$, androcônia com escamas creme, do mesmo tamanho que aquela da face dorsal da asa posterior.

$\mathrm{Na}$ face ventral da asa posterior, próxima ao meio da margem costal, faixa basal preta de aproximadamente $2 \mathrm{~mm}$ se projeta até o primeiro terço de $2 \mathrm{~A}$; quando passa por Rs, faixa pós-basal se forma, em semicírculo, e também se projeta até $2 \mathrm{~A}$ pouco distal à anterior. Ponto preto com interior creme sobre Rs, na metade distal da margem costal. Linha submarginal escura e crenulada, antecedida por faixa em branco violáceo e por outra anterior a essa, castanho; pontos creme sobre essa faixa. Toda a margem externa crenulada, com projeção acentuada acompanhada pela veia $\mathrm{CuA}$.

Genitália (Fig. 63A-E). Unco reto, com projeção lateral denteada. Subunco retangular, pouco mais estreito na base; lateralmente, pouco antes da metade até a porção distal, várias projeções esclerotinizadas, como espinhos; borda distal completamente denteada. Valva projetada de forma a alcançar a extremidade do unco; extremidade distal com duas projeções, a anterior com vários dentes e a distal em ponta única. Juxta, em vista ventral, com forma de $\mathrm{U}$.

Fêmea (Figs 60 e 64). Asa anterior: comprimento da margem costal - 32 a $34 \mathrm{~mm}$; margem externa $-24 \mathrm{~mm}$; largura da asa $-23 \mathrm{~mm}$. Asa posterior: comprimento da margem costal - 26 a $27 \mathrm{~mm}$; margem externa - 26 a $27 \mathrm{~mm}$; maior comprimento da asa - 30 a $31 \mathrm{~mm}$.

Cabeça e apêndices, tórax e abdome castanho.

Face dorsal das asas anterior e posterior, castanho uniforme. Margem externa em ambas as asas com faixa de aproximadamente $1 \mathrm{~mm}$ de largura pouco mais clara que o restante. $\mathrm{Na}$ asa anterior, o ápice e o torno são retraídos em relação a parte média e na posterior, margem externa totalmente crenulada, com projeção pouco acentuada acompanhada pela $\mathrm{CuA}_{1}$.

$\mathrm{Na}$ face ventral de ambas as asas, o castanho é mais claro e com algumas escamas brancas com reflexos violáceos. Na asa anterior, como nos machos, uma faixa diagonal de escamas mais claras divide a asa em duas partes; a distal mais 

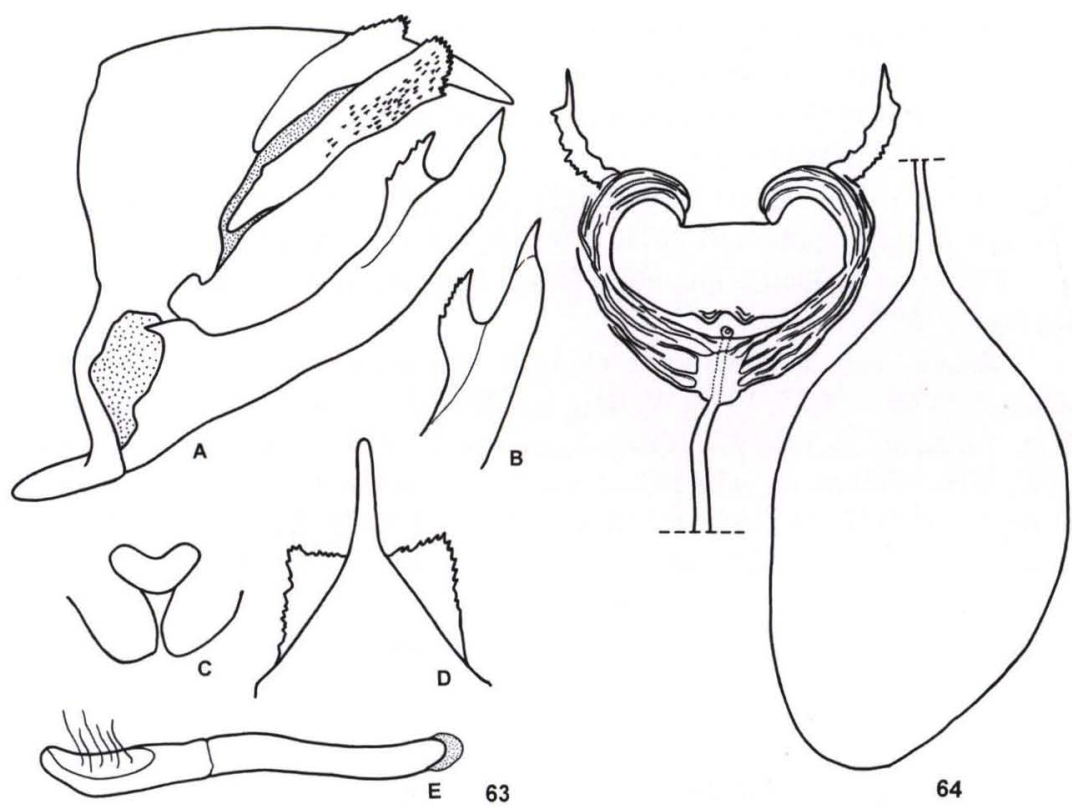

Figs 63-64. Narope testacea. (63) Genitália masculina: (A) vista lateral, (B) vista lateral interna, (C) juxta, vista ventral, (D) tegume/unco, vista dorsal, (E) edeago, vista lateral; (64) genitália feminina, vista ventral.

escura e a proximal mais clara. A asa posterior, com faixa submarginal de escamas claras, seguida de outras duas semelhantes, uma mediana e outra pós-basal. Na faixa escura, entre as claras submarginal e mediana, uma série de pontos escuros na margem costal, passando a creme próximo ao ângulo anal.

Genitália (Fig. 64). Lamela pós-vaginal em forma de placa esclerotinizada, com porção médio-anterior arredondada e com projeções distais. Lamela ante-vaginal pequena em relação à pós-vaginal. Duto da bolsa e corpo da bolsa com o mesmo tamanho, porém completamente distintos; bolsa arredondada.

Discussão. A espécie pode a primeira vista ser confundida com $N$. cyllarus, pois ambas possuem coloração castanho amarelo ferrugíneo, porém podem ser distinguidas pela presença de faixa submarginal em ambas as asas, machos e fêmeas com o mesmo padrão de coloração e pelo fato de só ocorrerem na região sul da América do Sul, enquanto que, em $N$. testacea a faixa em ambas as asas é marginal e enegrecida, as fêmeas são castanho claro sem ferrugíneo e distribuem-se pelo México e Panamá.

De $N$. minor sp. n., descrita a seguir, se distingue pela presença de linha submarginal escura nas asas posteriores e pelo aspecto da projeção lateral do unco, e de $N$. cyllastros da qual foi considerada por STICHEL (1904) como subespécie, pela coloração das asas anterior e posterior, aspectos da genitália masculina como forma do unco, subunco e valva. 
Distribuição espacial (Fig. 58). MÉXICO, Chiapas: Motozintla; Oaxaca: Candelaria Loxicha. PANAMÁ, Chiriqui.

Distribuição temporal. Entre os exemplares estudados, os adultos voam entre os meses de julho a novembro.

Etologia. Desconhecida. DeVRIES (1987) cita aspectos do comportamento de Narope testacea, porém a citação refere-se à Narope minor $\mathbf{s p .} \mathbf{n}$.

Planta hospedeira e imaturos. Desconhecidos, mas acredita-se que devam alimentar-se de Poaceae.

Material estudado. MÉxICO, Chiapas: Motozintla, San Jeronimo, 600 m, 5 machos, 11.VIII - 14.XI. 1973, Welling leg. (UFPC). Oaxaca, Candelaria Loxicha, 500 m, 1 macho, 25.VII.1976 (OM), 2 machos, 17.VIII.1976, 7.X.1982, 1 fêmea, 28.VII.1976, Welling leg. (UFPC), 1 macho e 1 fêmea, 22.IX.1971 e 24.X.1970, Welling leg. (CGCM) 1 macho e 1 fêmea, 28.VII-27.VIII.1976(UFPC). PANAMÁ, Chiriqui, 1 macho e 1 fêmea (lectótipo e paralectótipo) (ZMHB).

\section{Narope minor Casagrande, sp. $\mathbf{n}$.}

Figs 61-62, 65-67

Narope cyllastros testacea; DeVries, 1987. Butt. Costa Rica, p.256, pl. 41, figs 6, 7 (macho d, v); biol., planta hosp., dg., etol.-Maes, 1999. Ins. Nicaragua, vol.III, p. 1387; dg., planta hosp., etol. -Penz, Aiello \& Strygley, 2000. Jour. Lep. Soc. 53 (4): 149; planta hosp.

Material tipo. HOLÓTIPO macho na Coleção de Entomologia Padre Jesus Santiago Moure, Departamento de Zoologia, Setor de Ciências Biológicas, Universidade Federal do Paraná, Curitiba, Paraná, Brasil, com as seguintes etiquetas: /HOLOTYPE/ Chiltepec, Oaxaca, México, 20.VIII.1973, Welling leg/ DZ 4724/ Narope minor Casagrande, Holotype, M. M. Casagrande det. 2002/. ALÓTIPO na coleção de Lepidoptera do "National Museum of Natural History", Smithsonian Institution, Washington, USA, com as seguintes etiquetas: /ALLOTYPE/ Panamá, Veraguas, Ballena, 2 feb. 1979, coll. G. E. Small/ Narope minor Casagrande, Alotype, M. M. Casagrande det. 2002/.PARÁTIPOS: MÉXICO, Oaxaca: Chiltepec, 1 macho, VIII-1964, Welling leg. (CGCM), 1 macho, 2.VII.1973, DZ 805 (UFPC); Tapalapam, 1 macho, 25.VIII.1982, Cota leg., DZ 4818 (UFPC); Candelária Loxicha, 500 m, 1 macho, 7.X.1982, Welling leg., DZ 4730 (UFPC). PANAMÁ, Panamá: Canal Área, 2 machos, 2-4.VI.1970, G.B. Small leg., (USNM), Darién: Cerro Pirre, Cana, 400m, 1 macho, 4.VIII.1981, G.B. Small Jr. leg., (MHNL), Herrera: Chepo, 700 m, 1 fêmea, 25. XII. 1984, G.B. Small Jr. leg., (MHNL), todos etiquetados como parátipos da seguinte forma: /PARATYPE/ Narope minor Casagrande, Paratype, M.M. Casagrande det. 2002/.

Diagnose. Asas anterior e posterior, na face dorsal, laranja ferrugíneo, pequena mancha preta, próxima à margem externa entre $\mathrm{M}_{1}-\mathrm{M}_{2}$, linha submarginal escura na asa posterior, do macho. Na fêmea com a face dorsal das asas em castanho claro, sem ferrugíneo. Genitália masculina com unco reto e com projeção lateral arredondada e serrilhada, dobrada dorsalmente formando uma crista sobre o unco.

Descrição. Macho (Figs 61 e 65). Asa anterior: comprimento da margem costal - 26 a $30 \mathrm{~mm}$; margem externa - 18 a $20 \mathrm{~mm}$; largura da asa -17 a $19 \mathrm{~mm}$. 
Asa posterior: comprimento da margem costal - 18 a $20 \mathrm{~mm}$; margem externa - 18 a $20 \mathrm{~mm}$; maior comprimento da asa - 22 a $24 \mathrm{~mm}$.

Cabeça, tórax e abdome castanho. Antenas ferrugíneas.

Asas anterior e posterior na face dorsal laranja ferrugíneo. Ápice da asa anterior com escamas pretas que diminuem progressivamente em direção ao centro da asa; pequena mancha preta próxima à margem externa entre $\mathbf{M}_{1}-\mathbf{M}_{2}$. Asa posterior pouco mais escura que anterior, ápice segue o mesmo padrão da anterior; linha submarginal preta e crenulada, como a margem da asa, e a maior projeção acompanhada pela $\mathrm{Cu}_{1} \mathrm{~A}$; androcônia oval de tamanho médio, creme, pouco além da bifurcação Rs-M1, sobre Rs.

Face ventral da asa anterior palha, com pequenos conjuntos de escamas castanho. Do ápice da asa até o meio de $2 \mathrm{~A}$, faixa diagonal de aproximadamente 2 $\mathrm{mm}$ de largura e com escamas claras, dividindo a asa em duas áreas; a distal mais escura e a proximal clara. Outras duas faixas, escuras: a basal desde a margem costal, passando pela célula discal até próximo de $2 \mathrm{~A}$ e a outra pós-basal, da margem costal e passando pelas bases de $R_{2}, R_{3}, R_{4}$ e $R_{5}$, até $2 A$. Sobre a metade proximal de $2 A$, androcônia com escamas ferrugíneas, do mesmo tamanho que aquela da face dorsal da asa posterior.

Face ventral da asa posterior, com padrão de coloração semelhante à asa anterior, porém com um número muito maior de aglomerados de escamas escuras e com aparência marmorizada. Faixa basal escura desde o meio da margem externa, passando pela base da bifurcação Rs-M 1 , pelo centro da célula discal até próximo à base de $3 \mathrm{~A}$; faixa pós-basal com início na basal, na área próxima à dcs, formando uma curva até pouco além do meio de $3 \mathrm{~A}$. Sobre a linha submarginal escura, se encaixam escamas claras de reflexo violáceo. Entre $\mathrm{Sc}+\mathrm{R}_{1}$ - Rs, ponto escuro com parte interna creme, seguido de outros, menores, entre as veias subsequentes, formando um circulo; os dois últimos maiores, de escamas creme com parte interna escura.

Genitália (Fig. 65A-E). Unco reto com projeção lateral arredondada e serrilhada que se dobra dorsalmente formando uma crista sobre o unco. Subunco retangular, na extremidade distal o dobro da largura da extremidade basal, lados externo e mediano distal com inúmeros espinhos esclerotinizados. Valva projetada, não ultrapassando o unco; extremidade distal com duas projeções, a anterior levemente serrilhada e com um dente projetado e a distal com dois ou três dentes (valvas assimétricas). Juxta, em vista ventral, com forma de um $\mathrm{V}$ expandido, com a porção interna serrilhada.

Fêmea (Figs 62 e 66). Asa anterior: comprimento da margem costal - 30 $\mathrm{mm}$; margem externa $-20 \mathrm{~mm}$; largura da asa $-20 \mathrm{~mm}$. Asa posterior: comprimento da margem costal $-23 \mathrm{~mm}$; margem externa $-23 \mathrm{~mm}$; maior comprimento da asa $-26 \mathrm{~mm}$.

Cabeça e apêndices, tórax e abdome castanho.

Asas anterior e posterior com a face dorsal completamente castanho. Linha marginal com no máximo $1 \mathrm{~mm}$ de largura, com escamas mais claras que o restante da asa. Discreta nuance ferrugem após a célula discal da asa anterior. 


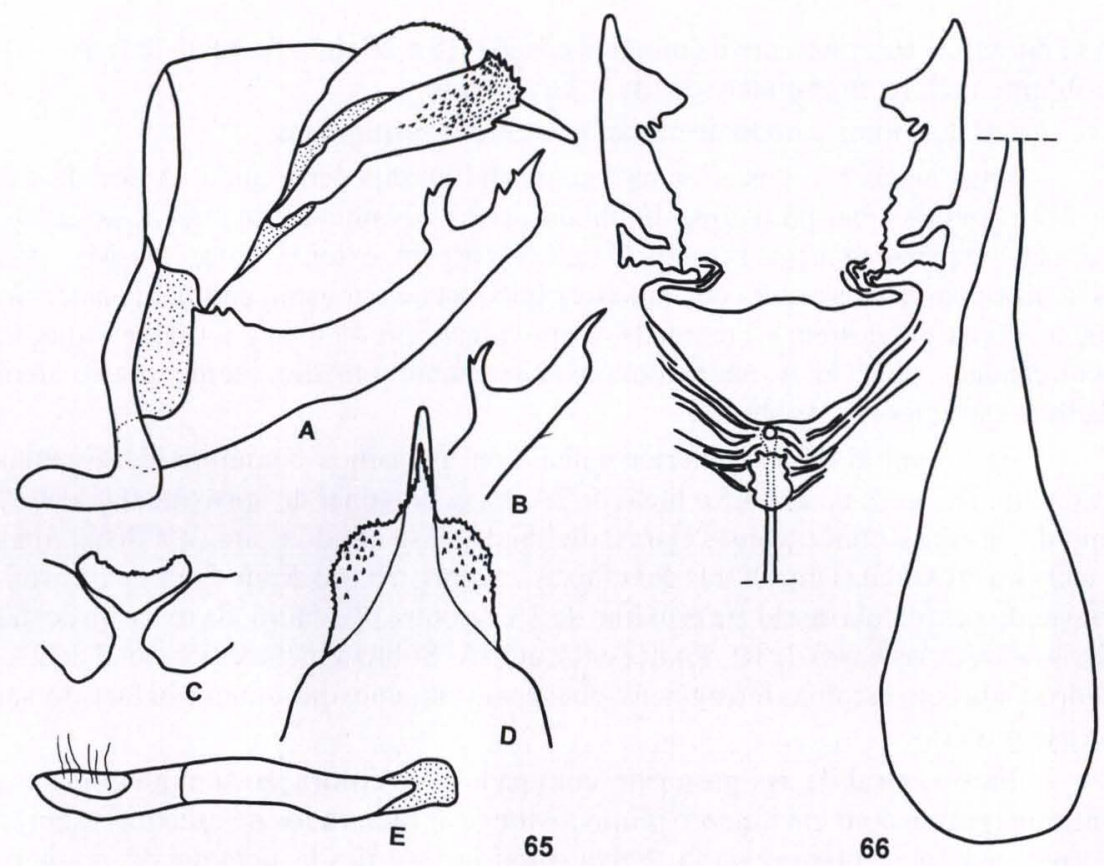

Figs 65-66. Narope minor sp. n. (65) Genitália masculina: (A) vista lateral, (B) valva, vista lateral interna, $(C)$ juxta, vista ventral, (D) tegume/unco, vista dorsal, (E) edeago, vista lateral; (66) genitália feminina, vista ventral.

Face ventral parda acinzentado. Como nos machos, asa anterior com linha diagonal desde o ápice até o meio de $2 \mathrm{~A}$, área marginal castanho claro; área basal mais clara e com reflexos em prata acentuado entre $\mathrm{R}_{3}, \mathrm{R}_{4}$ e $\mathrm{R}_{5}$; ápice da asa retraído. Asa posterior com vários e pequenos conjuntos de escamas escuras; ponto escuro, destacado em $\mathrm{Sc}+\mathrm{R}_{1}$-Rs, no meio da margem costal; margem da asa crenulada, com projeção acompanhada pela veia $\mathrm{M}_{3}$.

Genitália (Fig. 66). Lamela pós-vaginal com formato de meia-lua e com saliência mediana; lamela ante-vaginal fracamente esclerotinizada. Duto da bolsa e bolsa com aproximadamente o mesmo tamanho; corpo da bolsa alongado.

Discussão. Nas coleções examinadas e que dispõem de material desta espécie, estava misturado $\operatorname{com} N$. testacea. Porém $N$. minor $\mathbf{s p .}$. pode ser separada de $N$. testacea, pelo menor tamanho, coloração castanho ferrugíneo das asas e pela faixa submarginal na asa posterior, além de aspectos nas genitálias masculina e feminina.

Distribuição espacial (Fig. 67). MéxICo, Oaxaca: Chiltepec, Tapalapam, Candelária Loxicha. PANAmá, Panamá: Canal Area; Veraguas: Ballena; Darién, Cerro Pirre; Herrera: Chepo. Costa RicA, San Jose: Santa Ana, Pozo Azul de Pirris. 


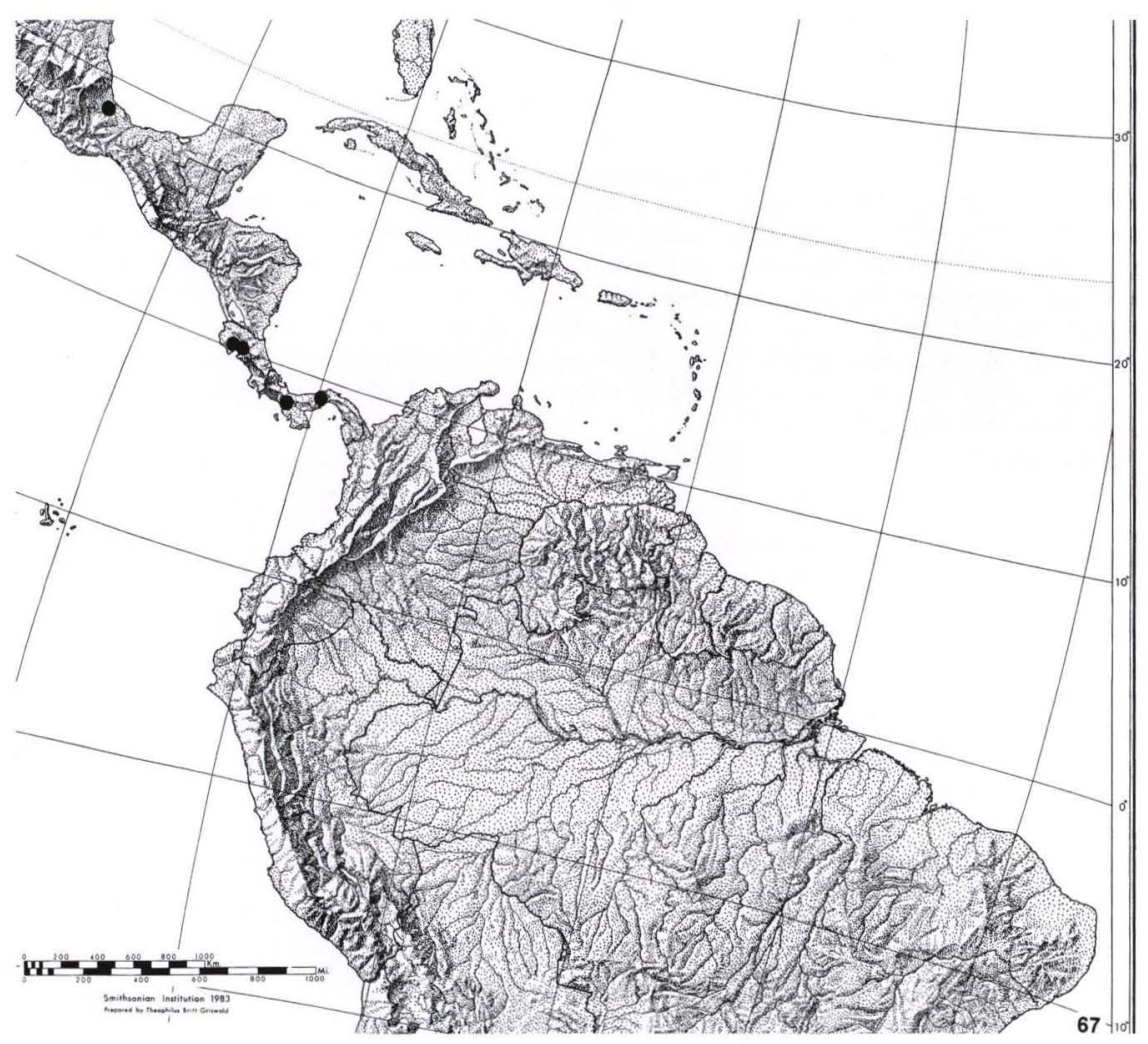

Fig. 67. Distribuição espacial. (•) Narope minor sp. n.

Distribuição temporal. Com base no material estudado, os adultos voam nos meses de fevereiro e de junho, agosto, outubro e dezembro.

Etologia. Segundo DEVRIES (1987), mencionada como $N$. testacea, na Costa Rica, voam em locais acima de 1200 metros no lado do Pacífico, podem ser capturadas após o escurescer com banana em decomposição e na luz quando escuro; os machos voam de quatro a dez metros de altura em trilhas e são muito raros.

Planta hospedeira e imaturos. DeVRIES (1987) cita, sob o nome de $N$. testacea, como planta hospedeira bambu (Poaceae), sendo o ovo branco com círculos concêntricos em vermelho e bastante esculturado, no que é seguido por PENZ et al. (2000).

Etimologia. O nome é alusivo ao pequeno tamanho da espécie.

Material estudado. Todos os exemplares mencionados no item Material tipo. 


\section{Narope cyllabarus Westwood, 1851}

Figs 22, 68-72

Narope cyllabarus Westwood, 1851, in Doubleday. Gen. Diurn. Lep. 2, p. 349; Bolívia; BM(NH).Herrich-Schäffer, 1865. Corr.- Blatt zool.- min. Ver. Regensburg 19: 65; cit-- Kirby, 1871. Syn. Cat. Diurn. Lep., p. 129; cat.- Staudinger, 1887, in Staudinger \& Schatz. Exot. Schmett. 1, p. 218; sist., dg.-Stichel, 1904, in Wytsman. Gen. Ins. 20, p. 15; cat., dg.-Stichel, 1909. Tierreich 25, p. 42, 48; cat., sist., dg.-Fruhstorfer, 1912, in Seitz, Gross-Schmett. Erde 5, p. 330; sist., dg.Stichel, 1916. Neue Beitr. syst. Insektenk. 1: 7; sist., dg.-Stichel, 1932. Lep. Cat. 51, p. 16; cat., dg.- Hemming, 1941. Jour. Soc. Bibl. Nat. Hist. 1(2): 451; sist., dg.- Lewis, 1973. Butt. World, p. 29 , fig. 10 (d), p. 222, dg.- Lewis, 1975. Marip. Mundo, p. 29, fig. 10 (d), p. 222; dg.- Lamas, 1983. Rev. Soc. Mex. Lep. 8: 16; dg.- D’Abrera, 1987. Butt. Neotrop. Reg. 3, p. 392, figs (macho d, v); sist., dg.- Robbins et al., 1996, in Wilson \& Sandoval. Manu, p. 229; dg.- Ramos, 2000. Jour. Res. Lepid. 35:33; etol.

Narope sutor; Piñas \& Manzano, 1997. Marip. Equador, p. 62, fig. 218 (d); err. ident.; dg.

Histórico. WESTWOOD (1851) ao citar a distribuição geográfica para a espécie tipo do gênero, $N$. cyllastros, até então somente figurada, inclui duas novas espécies: $N$. cyllarus e $N$. cyllabarus, esta baseada em macho(s) da Bolívia. As citações que seguem à descrição original, ampliam a distribuição geográfica.

Material tipo. No “The Natural History Museum", Londres, Inglaterra, um síntipo macho foi encontrado e é aqui designado como LECTÓTIPO, com o objetivo de garantir a adequada identificação da espécie, com as seguintes etiquetas: /Type/ Bolívia/ Narope cyllabarus Westw. G. \& S. p.349/ B.M. TYPE Nº 6116 Narope cyllabarus or Westw./ LECTOTYPE/ Narope cyllabarus Westwood, 1851, Lectotype, M. M. Casagrande det. 2002/.

Diagnose. Face dorsal das asas anterior e posterior ferrugíneo escuro. Ápice e margem externa da asa anterior com escamas escuras. Pequeno ponto de escamas escuras, próximo à margem externa, entre $\mathrm{M}_{1}-\mathrm{M}_{2}$, e outro sobre a discocelular inferior. Tegume se projeta distalmente até próximo ao ápice do unco.

Descrição. Macho (Figs 68 e 70). Asa anterior: comprimento da margem costal - 32 a $36 \mathrm{~mm}$; margem externa - 23 a $25 \mathrm{~mm}$; largura da asa - 22 a $25 \mathrm{~mm}$. Asa posterior: comprimento da margem costal - 20 a $23 \mathrm{~mm}$; margem externa - 24 a $25 \mathrm{~mm}$; maior comprimento - 25 a $28 \mathrm{~mm}$.

Cabeça e apêndices, tórax e abdome ferrugíneo.

Face dorsal das asas anterior e posterior ferrugíneo escuro. Ápice e margem externa da asa anterior com escamas escuras; pequeno ponto de escamas escuras, próximo à margem externa, entre $\mathrm{M}_{1}-\mathrm{M}_{2}$, e outro sobre a discocelular inferior. Ápice e linha submarginal da asa posterior enegrecido e mancha de escamas escuras sobre a base de $\mathrm{M}_{2}$. O bordo da margem externa, liso e sem projeções acompanhadas por veias; androcônia oval, de tamanho grande, creme, pouco além da bifurcação Rs-M1, sobre Rs.

Face ventral das asas anterior e posterior amarelo com inúmeros aglomerados em pontos ou linhas de escamas escuras. Em ambas as asas, faixa marginal com aproximadamente $1 \mathrm{~mm}$ de largura em castanho e faixa submarginal castanho escuro. $\mathrm{Na}$ asa anterior, pouco além da linha marginal, entre $\mathrm{M}_{1}-\mathrm{M}_{2}$, ponto escuro com centro creme; faixas basal e pós-basal em castanho; sobre a metade proximal de $2 \mathrm{~A}$, androcônia com escamas creme, pouco maior que aquela da face dorsal da 

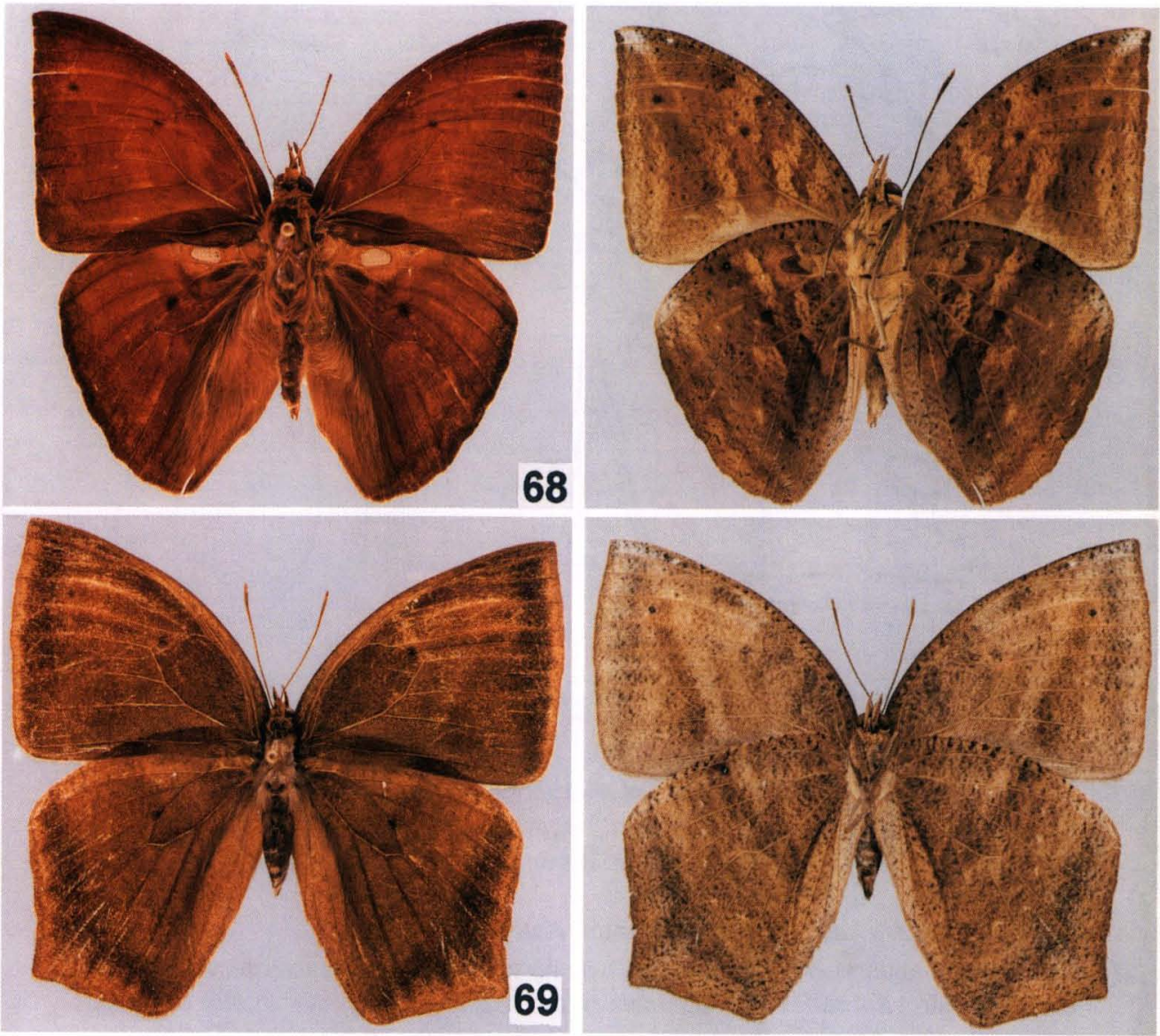

Figs 68-69. Narope cyllabarus. (68) Macho, vistas dorsal e ventral; (69) fêmea: vistas dorsal e ventral.

asa posterior. $\mathrm{Na}$ asa posterior faixa basal com início no meio da margem costal e até o meio da célula discal; faixa pós-basal da metade distal da célula discal até $2 \mathrm{~A}$; faixa mediana, da metade distal da margem costal até próxima ao ângulo anal; linha submarginal castanho escuro com pontos mais escuros; da faixa mediana até a linha submarginal castanho com alguns pontos amarelos.

Genitália (Fig. 70A-E). Unco curvo, com acentuada convexidade dorsal e margem inferior levemente serrilhada e ponta projetada. Tegume se projeta distalmente, em ponta, até a porção mais dorsal da convexidade do unco. Subunco retangular, com constrição mediana, porção distal com alguns espinhos pontudos. Valva estreita e longa, projetada para além do unco; borda dorsal serrilhada. Juxta, em vista ventral, em forma de $\mathrm{V}$ expandido, na margem distal com leve depressão mediana. 

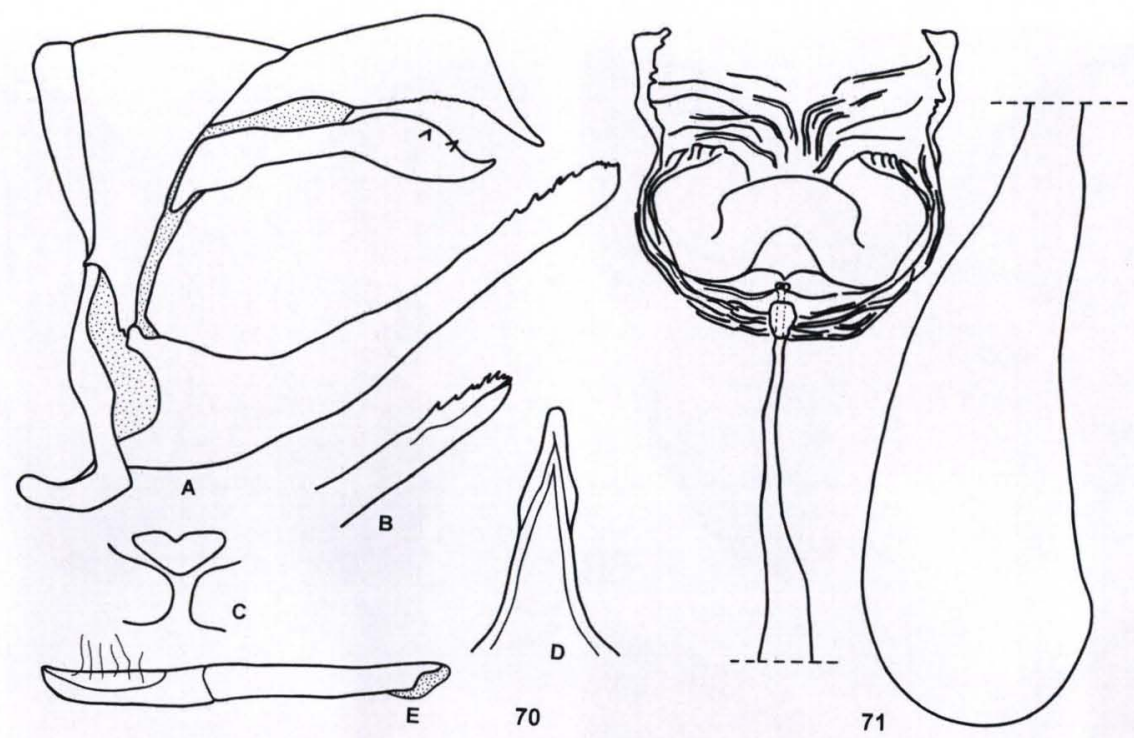

Figs 70-71. Narope cyllabarus. (70) Genitália masculina: (A) vista lateral, (B) vista interna da valva, (C) juxta; (D) tegume/unco, vista dorsal, (E) edeago; (71) genitália feminina, vista ventral.

Fêmea (Figs 69 e 71). Asa anterior: comprimento da margem costal - 37 a $40 \mathrm{~mm}$; margem externa - 27 a $30 \mathrm{~mm}$; largura da asa -25 a $30 \mathrm{~mm}$. Asa posterior: comprimento da margem costal - 27 a $31 \mathrm{~mm}$; margem externa - 28 a $30 \mathrm{~mm}$; maior comprimento -36 a $38 \mathrm{~mm}$.

Cabeça, tórax e abdome castanho. Antenas ferrugíneas.

Asas anterior e posterior com a face dorsal castanho. Margens costal e externa castanho claro. Sobre $\mathrm{M}_{1}$ e $\mathrm{M}_{2}$ algumas escamas ferrugíneas. Asa posterior com faixa marginal castanho claro, com linhas em castanho escuro e discreto ferrugíneo.

Face ventral amarelo claro. Como nos machos, toda a superfície ventral, com inúmeros e pequenos pontos e traços formados por escamas escuras. Na asa anterior manchas e faixas de contorno pouco definido em castanho claro. $\mathrm{Na}$ asa posterior o mesmo desenho que no macho com relação às faixas basal e pós-basal. Margem externa e linha submarginal em castanho. Do meio da margem costal até à margem interna, em semicírculo, pequenos pontos, o primeiro escuro e os demais em amarelo claro, sobre área castanho claro; estes pontos estão nos espaços entre as veias. Margem externa lisa, exceto por projeção acompanhada pela M3.

Genitália (Fig. 71). Lamela pós-vaginal retangular, com projeções laterais e borda distal arredondada; projeções laterais dobradas para a região distal. Lamela ante-vaginal pequena. Duto da bolsa pouco menor que o corpo da bolsa; bolsa copuladora alongada.

Discussão. A coloração ferrugínea da face dorsal das asas anterior e posterior, o desenho na face ventral de ambas as asas com amarelo intenso e aspectos relacionados à genitália, como a convexidade do unco e espinhos no subunco separam-na de $N$. obidos $\mathbf{s p .}$. ., com a qual pode ser confundida. 
Distribuição espacial (Fig. 72). GUIANA INGLESA, Bartica: Kartabo. COLÔMBIA, Meta: Rio Negro. EQUAdOR, Chimborazo: Riobamba; Bolívar: Balzapamba; Santiago-Zamora: Macas, Normandia. Peru, Madre de Dios: (Pakitza); Cuzco: Cuzco (Salvacion); Junín: Rio Perené, Chanchamayo, Satipo; Amazonas: Rio Santiago; Loreto: Iquitos; San Martin: Jepelacio. BolíviA, Cochabamba: Chapare (Cristal Mayo); Santa Cruz: Buenavista (Ichilo), Rio Japacani; La Paz. BrASIL, Amazonas: São Paulo de Olivença, Manicoré; Rondônia: Guajarámirim, Jarú, Rio Jamari, Cacaulândia; Mato Grosso: Buriti, Cáceres (Cel. Rio Branco); Mato Grosso do Sul: Nioaque; Distrito Federal: Brasília, Cabeça de Veado (Distrito Federal); Goiás: Rio Araguaya (Ilha do Bananal).

Distribuição temporal. Pelo material estudado, pode-se concluir que a espécie voa durante o ano todo.

Etologia. Machos são atraídos para armadilhas com iscas de frutas em decomposição.

Planta hospedeira e imaturos. Desconhecidos, mas acredita-se que devam alimentar-se de Poaceae.

Material estudado. Guiana InglesA, Bartica: Kartabo, 1 macho, 1920 (USMN). COlÔMBIA, Meta: Rio Negro, 1 macho, 17.I.1971, Brown leg. (KB), 1 macho, 7.VIII.1971, Schmidt-Mumm leg. (UFPC). EQUADOR, Chimborazo: Riobamba, 2798m, 1 macho (BMNH); Bolivar: Balzapamba, 1 macho (AME); Santiago-Zamora: Macas, Normandia, 1 macho (CU). PERU, Madre de Dios, Parque Manu, Pakitza, 340m, 11 machos, 27.IX-20.X.1991, Casagrande \& Mielke leg. (UFPC); Cuzco: Cuzco, Salvacion, 400 m, 1 macho, Büche leg. (UFPC); Junín: Rio Perené, 300-400 m, 4 machos, IX-XI.1987, Tello leg. (OM), Chanchamayo, 2 machos, VII (BMNH), 1 macho, V.1961 (CU), Satipo, 1 macho (AMNH); Amazonas: Rio Santiago, 3 machos, 14-17.X.1930 (AMNH); Loreto, Iquitos, 100 m, XII.1988, Büche leg. (UFPC); San Martin: Jepelacio, 1 macho (AMNH). BolíviA: 1 macho (lectótipo) (BMNH), Cochabamba: Chapare, Cristal Mayo, 600 m, 2 machos, sem data e II.1961 (UFPC), 1 macho, X.1954 (AME); Santa Cruz: Buenavista, Ichilo, 2 machos (UFPC), 1 macho (AME), Rio Japacani, 600 m, 4 machos, Steinbach leg. (CMP); La Paz: 1 macho, Garlepp leg. (BMNH). BRASIL, Amazonas: São Paulo de Olivença, 1 macho (UFPC); Manicoré, 1 macho (UFPC), 1 macho (BMNH); Rondônia: Rio Madeira, Guajarámirim, 1 macho, 11-24.VIII. 1943 (MNRJ), Jarú, 2 machos, 5-10.VII.1976, Callaghan leg. (AME), 1 macho, 5-8.IX.1976, Brown leg. (KB); Rio Jamari, Cachoeira do Samuel, 1 macho, V.1944, Parko leg. (UFPC); Cacaulândia, 1 fêmea, 8-19.XI.1994, Mielke leg. (OM); Mato Grosso: Buriti, 26.V.1969, Brown leg. (KB); Cáceres, Cel. Rio Branco, Rio Vermelho, 400 m, 1 fêmea, 2.VII.1972, Mielke \& Brown leg. (UFPC); Mato Grosso do Sul: Nioaque, 1 macho, 9.VII.1967 (UFPC); Distrito Federal: Brasília, Cabeça de Veado, 2 fêmeas, 28.XII.1980, 27.XI. 1981, 1 macho, 9.IV.1981, Ferreira leg. (UFPC), Brasília, BR 251, KM 0, Reserva Ecológica IBGE, 1 macho, 3.XI.1979, 2 fêmeas e 1 macho, 3-4.XII.1979, A. Negrett leg., 1 macho, 29.IX.1980, Ferreira leg. (UFPC); Goiás: Rio Araguaya, Ilha do Bananal (MNRJ). 


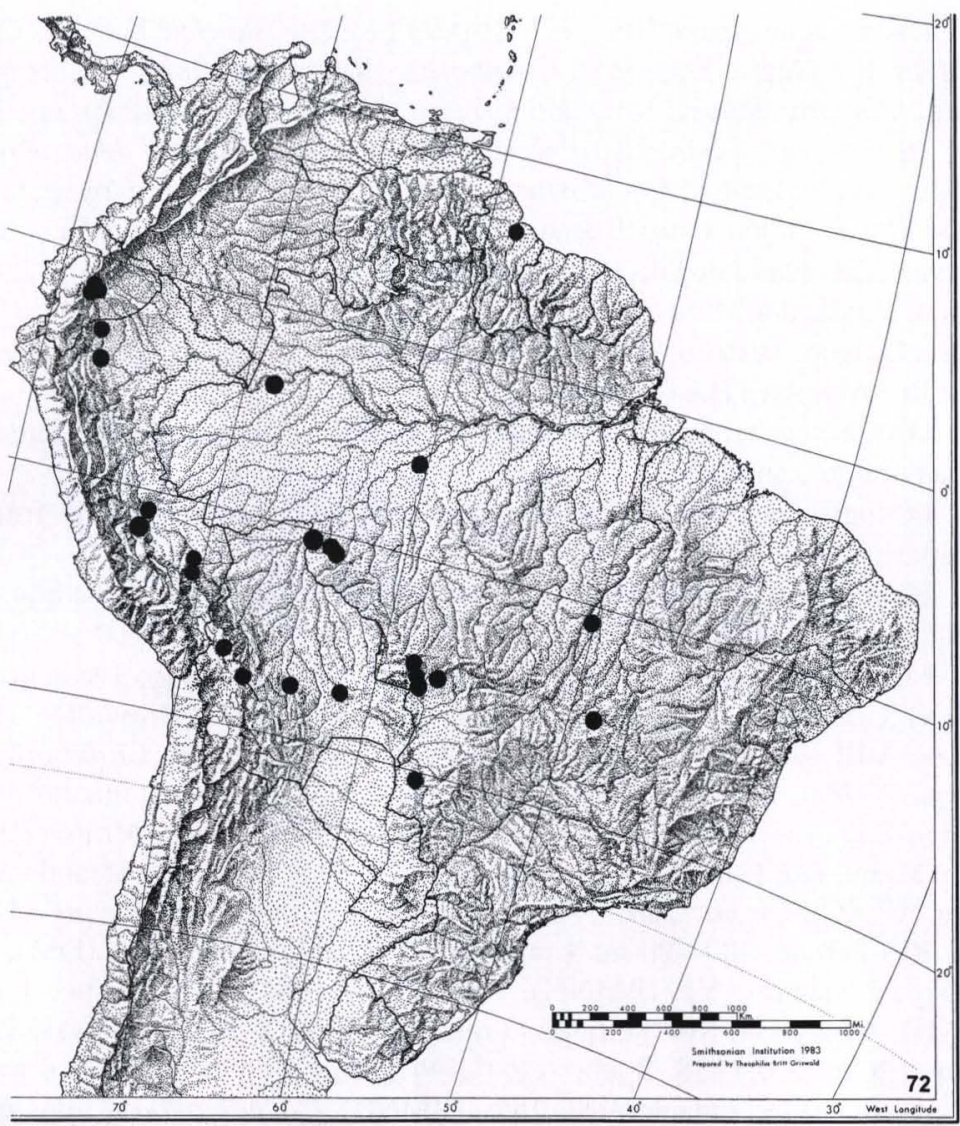

Fig. 72. Narope cyllabarus. Distribuição espacial.

Narope obidos Casagrande, sp. $\mathbf{n}$.

Figs 73-74, 76-78

Material tipo. HOLÓTIPO na Coleção de Entomologia Padre Jesus Santiago Moure, Departamento de Zoologia, Setor de Ciências Biológicas, Universidade Federal do Paraná, Curitiba, Paraná, Brasil, macho, com as seguintes etiquetas: /HOLOTYPE/ Óbidos, XI.1965/ DZ 4726/ Narope obidos Casagrande, Holotype, M.M. Casagrande det. 2002/. ALÓTIPO na Coleção de Entomologia Padre Jesus Santiago Moure, Departamento de Zoologia, Setor de Ciências Biológicas, Universidade Federal do Paraná, Curitiba, Paraná, Brasil, fêmea, com as seguintes etiquetas: / ALLOTYPE/ Altamira, Xingú, [Pará], Coleção Julius Arp/ DZ 4731/ Narope obidos Casagrande, Allotype, M.M. Casagrande det. 2002/. PARÁTIPOS: PERU, Madre de Dios: Pakitza, Parque Manu, 2 machos, 15 e 20.X.1991, Casagrande leg. 
DZ 4816, (UFPC) (MHNL). BRASIL, Pará: Itaituba, 1 fêmea, DZ 4817, (UFPC), Óbidos, 1 macho, VIII. 1960, DZ 3064, (UFPC); Mato Grosso: Sinop, Km 500 Estrada Cuiabá-Santarém, 1 macho, X-XI.1975, Roppa leg. DZ 4824, (UFPC); Espirito Santo: Colatina, 3 machos, 22-24.IX.1937, DZ 4825, 4810, 4811, (UFPC). Todos etiquetados como parátipos da seguinte forma:/PARATYPE/ Narope obidos Casagrande, Paratype, M.M. Casagrande det. 2002/.

Diagnose. Face dorsal das asas anterior e posterior castanho avermelhado ferrugíneo, mais intenso na margem costal e dentro da célula discal da asa anterior. Margens externas de ambas as asas não crenulada. Genitália masculina com unco de convexidade acentuada dorsalmente, subunco liso, terminando em ponta e valva estreita com borda dorsal denteada.

Descrição. Macho (Figs 73 e 76). Asa anterior: comprimento da margem costal - 32 a $34 \mathrm{~mm}$; margem externa - 24 a $25 \mathrm{~mm}$; largura da asa - 23 a $24 \mathrm{~mm}$. Asa posterior: comprimento da margem costal - 23 a $25 \mathrm{~mm}$; margem externa - 25 a $26 \mathrm{~mm}$; maior comnprimento - 26 a $27 \mathrm{~mm}$.

Cabeça e apêndices, tórax e abdome castanho, com vermelho ferrugíneo escuro.

Face dorsal das asas anterior e posterior castanho avermelhado ferrugíneo. $\mathrm{Na}$ asa anterior, com escamas em castanho avermelhado ferrugíneo na margem costal e dentro da célula discal; ápice com poucas escamas escuras sobre o castanho. $\mathrm{Na}$ asa posterior o castanho é pouco mais intenso; bordo da margem externa liso e sem projeções acompanhadas por veias; androcônia oval, de tamanho grande, creme, pouco além da bifurcação Rs-M $M_{1}$, sobre Rs.

Face ventral das asas anterior e posterior em castanho claro; vários pontos e linhas de escamas escuras, sobre a superfície de ambas as asas com maior intensidade na posterior. $\mathrm{Na}$ asa anterior, pouco antes da margem externa, entre $\mathrm{M}_{1}-\mathrm{M}_{2}$, pequeno ponto escuro, deste ponto até o meio de $2 \mathrm{~A}$ com faixa diagonal de aproximadamente $1 \mathrm{~mm}$ de espessura; faixa basal castanho, sobre o meio da célula discal; faixa pós-basal castanho e pouco mais larga, desde a margem costal, sobre as discocelulares até o meio de $2 \mathrm{~A}$; sobre a metade proximal de $2 \mathrm{~A}$, androcônia com escamas creme, pouco maior que aquela da face dorsal da asa posterior. Asa posterior com linha submarginal escura, com discreta sinuosidade entre $\mathrm{M}_{2}$ e $2 \mathrm{~A}$; faixa basal castanho, desde a margem costal até a base de $3 \mathrm{~A}$; paralela à basal, mas separada por área castanho claro, a faixa pós-basal em castanho escuro até o meio de $2 \mathrm{~A}$; faixa pós-mediana, também castanho, na metade distal da margem costal se extende até a linha submarginal; ausência de reflexos prata ou violáceos.

Genitália (Fig. 76A-E). Unco curvo, com bordas lisas, acentuada ponta distal e convexidade dorsal. O tegume se projeta distalmente, em ponta, até a porção mais dorsal da convexidade do unco. Subunco liso, retangular, com a porção proximal alargada e afilando em direção distal até terminar em ponta, esta se projetando além da convexidade do unco. Valva estreita e longa, projetada para além do unco; borda superior da metade distal provida de espinhos. Juxta, em vista ventral, com forma de $\mathrm{V}$ expandido, com borda distal arredondada e com suave depressão mediana.

Fêmea (Figs 74 e 77). Asa anterior: comprimento da margem costal - 39 mm; margem externa $-27 \mathrm{~mm}$; largura da asa $-25 \mathrm{~mm}$. Asa posterior: comprimento da margem costal $-27 \mathrm{~mm}$; margem externa - $27 \mathrm{~mm}$; maior comprimento - $34 \mathrm{~mm}$. 

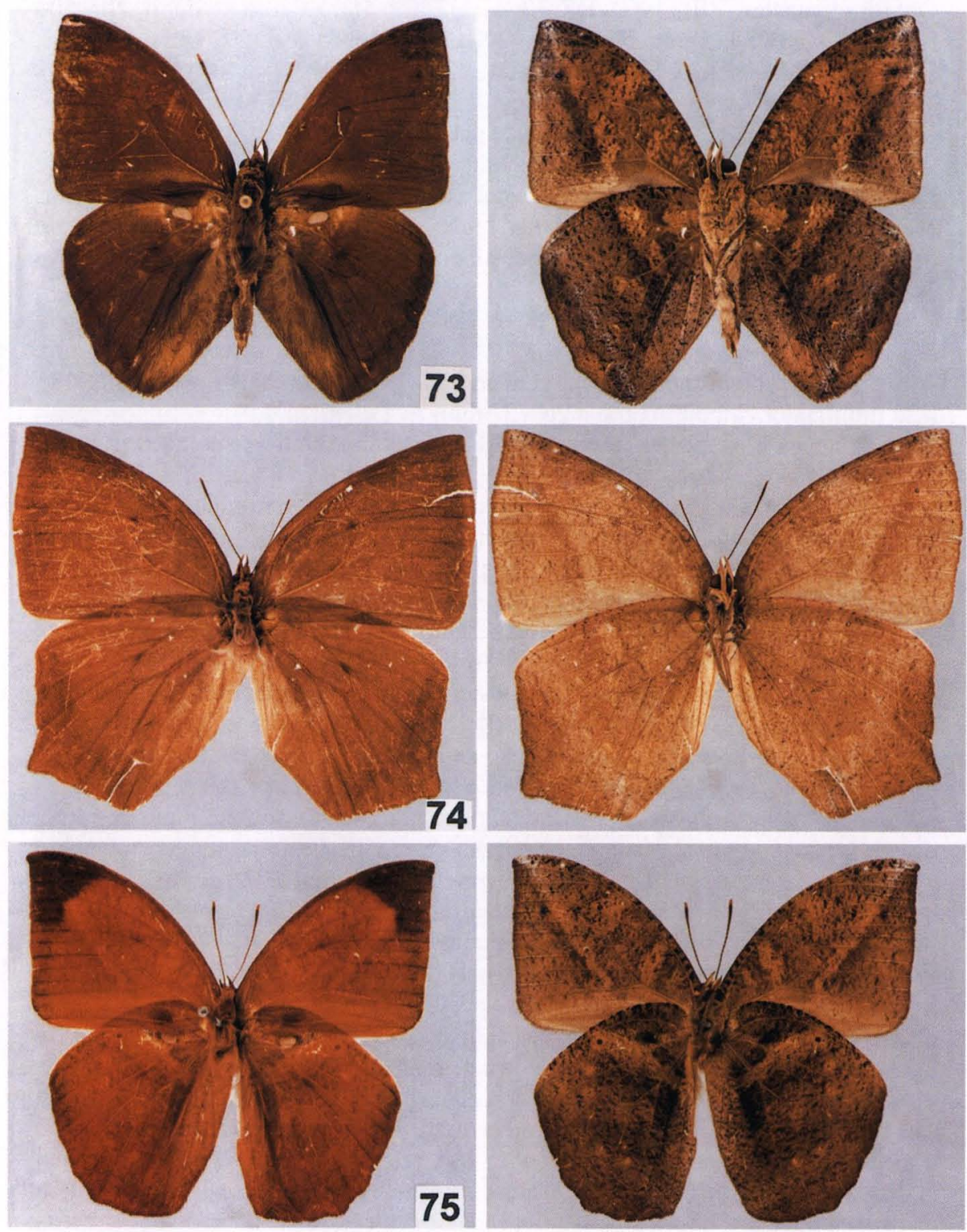

Figs 73-75. (73-74) Narope obidos sp. n.: (73) macho, holótipo, vistas dorsal e ventral; (74) fêmea, alótipo, vistas dorsal e ventral; (75) Narope ybyra sp. n., macho, holótipo, vistas dorsal e ventral. 

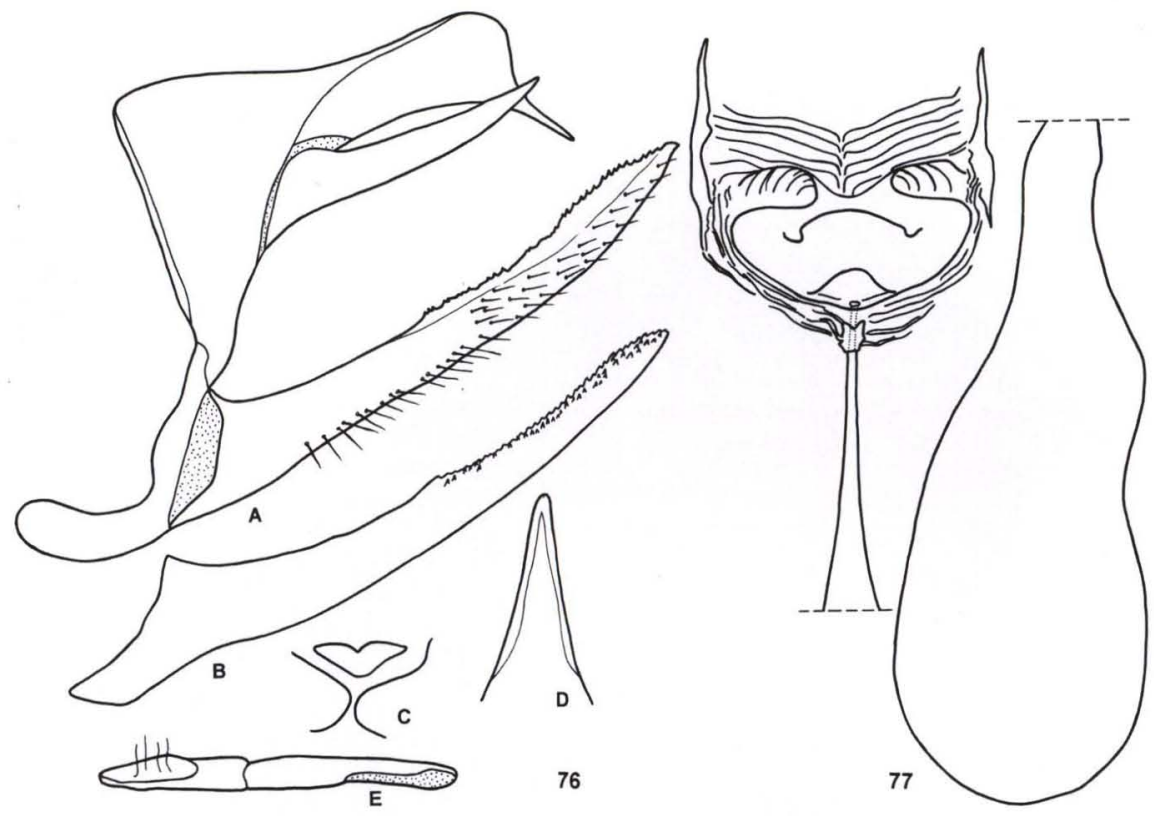

Figs. 76-77. Narope obidos sp. n. (76) Genitália masculina: (A) vista lateral, (B) valva, vista lateral interna, (C) juxta, vista ventral, (D) tegume/unco, vista dorsal, (E) edeago, vista lateral; (77) genitália feminina, vista ventral.

Cabeça e apêndices, tórax e abdome castanho.

Face dorsal das asas anterior e posterior castanho. Ápice da asa anterior e margem externa de ambas as asas com algumas escamas escuras. Como nos machos, toda superfície ventral, com inúmeros pequenos pontos e traços formados por escamas escuras. $\mathrm{Na}$ asa anterior, linha diagonal desde o ápice até o meio de $2 \mathrm{~A}$ define coloração mais escura para a área distal. $\mathrm{Na}$ asa posterior, margem externa projetada em ponta e acompanhada pela veia $\mathrm{M}_{3}$; linha submarginal denteada; da base até esta linha, castanho claro com reflexos violáceos, após a linha submarginal até a margem externa, castanho sem reflexos; pontos de escamas escuras, com centro branco, entre $\mathrm{Sc}+\mathrm{R}_{1}$-Rs, na metade distal da margem costal, seguido por outros, de cor creme, em semicirculo, nos espaços entre as veias subseqüentes.

Genitália (Fig. 77). Lamela pós-vaginal retangular, com extremidades arredondadas e braços laterais projetados e dobrados sinuosamente para a região dorsal. Lamela ante-vaginal pequena. Entre as lamelas pós-vaginal e a ante-vaginal pequena placa, com aproximadamente o mesmo tamanho da ante-vaginal. Duto da bolsa e bolsa com aproximadamente o mesmo tamanho; corpo da bolsa alongado.

Discussão. Narope obidos $\mathbf{s p}$. n. assemelha-se à $N$. cyllabarus, porém o castanho avermelhado ferrugíneo da face dorsal das asas é distinto do laranja ferrugineo de $N$. cyllabrus; androcônia da face dorsal da asa posterior pouco menor e características relacionadas à genitália masculina, como formato da valva e subunco liso e em ponta, as distinguem. 


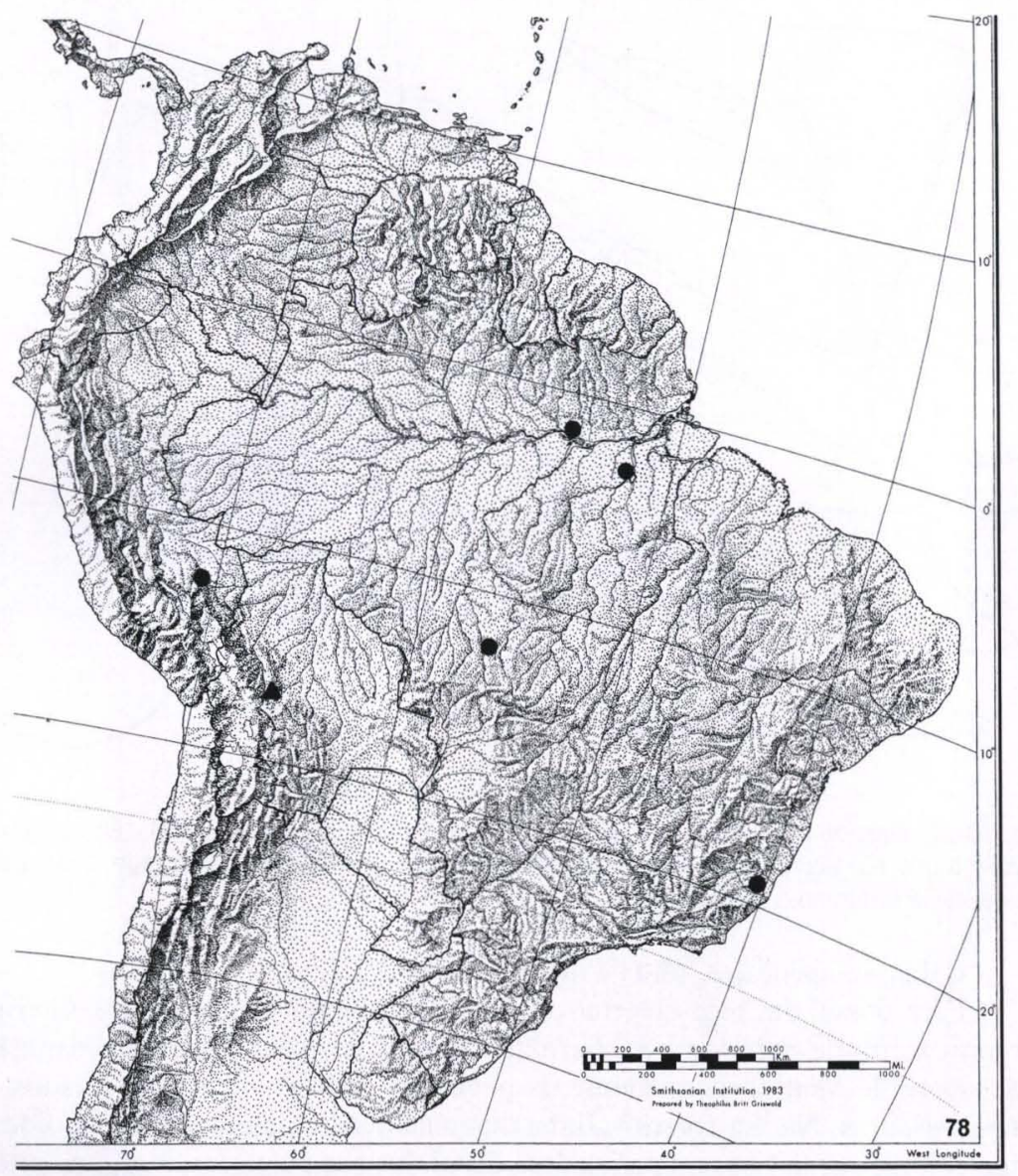

Fig. 78. Distribuição espacial. (•) Narope obidos sp. n., (A) Narope ybyra sp. n.

Distribuição espacial (Fig. 78). Peru, Madre de Dios: Parque Manu (Pakitza). Brasil, Pará: Altamira, Itaituba, Óbidos. Mato Grosso: Sinop (Rodovia Cuiabá - Santarém); Espírito Santo: Colatina.

Distribuição temporal. Entre o material estudado encontrou-se adultos voando entre os meses de agosto a novembro.

Etologia. Os machos coletados em Pakitza, no Parque Manu, foram atraídos para armadilhas com iscas de frutas em decomposição.

Planta hospedeira e imaturos. Desconhecidos, mas acredita-se que devam alimentar-se de Poaceae.

Etimologia. O nome é alusivo à localidade tipo, Óbidos (Pará).

Material estudado. Todos os exemplares citados no item Material tipo. 


\section{Narope syllabus Staudinger, 1887}

\section{Figs 79-85}

Diagnose. Face dorsal das asas anterior e posterior castanho avermelhado, sem manchas ou faixas. Margem externa de ambas as asas crenulada e com franja de escamas creme. Face ventral de ambas as asas castanho claro a amarelo. Subunco provido externamente com inúmeros espinhos.

\section{Chave para as subespécies}

1. Face ventral das asas anterior e posterior com amarelo intenso. Na face ventral da posterior linha submarginal denteada acompanhada por faixa de escamas claras com aproximadamente o dobro da espessura da linha submarginal; faixa pós-basal com o dobro da largura da basal ......N. syllabus syllabus

- Face ventral das asas anterior e posteriores castanho claro. Na face ventral da posterior linha submarginal quase reta e faixa de escamas claras de igual espessura que a linha submarginal; faixa pós-basal mais estreita que a basal

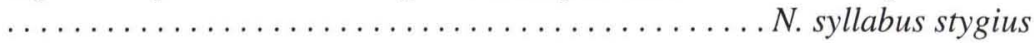

\section{Narope syllabus syllabus Staudinger, 1887}

Figs 79,82 e 85

Narope syllabus Staudinger, 1887, in Staudinger \& Schatz. Exot. Schmett. 1, p. 218; 1 macho [holótipo], Chanchamayo, [Junín].

Narope anartes syllabus; Fruhstorfer, 1912, in Seitz, Gross-Schmett. Erde 5, p. 329; sist., dg.- Lamas, 1969. Biota, Lima, 7: 290; dg.

Narope cyllastros syllabus; Stichel, 1916. Neue Beitr. syst. Insektenkunde 1: 7; dg.- Stichel, 1932. Lep. Cat. 51: 15; syn.: anartes; Stichel, 1904; Stichel, 1925; cat., dg.- Lamas, 1981. Rev. Soc.

Mex. Lep. 6: 30; dg.- D’ Abrera, 1987. Butt. Neotrop. Reg. 3, p. 390, figs (macho d, v); sist., dg.

Histórico. STAUDINGER (1887) descreveu a espécie com base em um macho. Os autores subseqüentes a mencionam como uma subespécie de $N$. anartes e $N$. cyllastros.

Material tipo. O HOLÓTIPO está na coleção do "Zoologisches Museum der Humboldt Universität", Berlim, Alemanha, e possui as seguintes etiquetas:/Origin./ Chanchamayo Thamm./ Narope not anartes but see Hewitson/ HOLOTYPE/ Narope syllabus Staudinger, 1887, Holotype, M. M. Casagrande det. 2002/.

Diagnose. Face dorsal das asas anterior e posterior castanho escuro avermelhado com margem externa escura e franja marginal de escamas claras. Face ventral de ambas as asas amarelo, com faixas e manchas castanho. Na asa posterior a faixa mediana com o dobro da largura da pós-basal.

Descrição. Macho (Figs 79 e 82). Asa anterior: comprimento da margem costal - 35 a $37 \mathrm{~mm}$; margem externa - 25 a $26 \mathrm{~mm}$; largura da asa - 23 a $24 \mathrm{~mm}$. Asa posterior: comprimento da margem costal -23 a $25 \mathrm{~mm}$; margem externa - 26 a $28 \mathrm{~mm}$; maior comprimento - $30 \mathrm{~mm}$.

Cabeça, tórax e abdome castanho avermelhado. Antenas ferrugíneas.

Face dorsal das asas anterior e posterior castanho escuro avermelhado. Margem 
externa em ambas as asas de coloração pouco mais escura, com aspecto esfumaçado que se dilui em direção à base. Na face dorsal da asa posterior, androcônia oval, de tamanho médio, creme, pouco além da bifurcação Rs-M1, sobre Rs.

Face ventral de ambas as asas amarelo intenso. $\mathrm{Na}$ asa anterior, do ápice até pouco antes do meio de $2 \mathrm{~A}$, faixa diagonal, imaginária definindo a área distal com escamas castanho e a proximal com escamas amarelo claro; na proximal, desde a base até metade da célula discal, castanho, incluindo a faixa basal e a pós-basal separada dessa por pequeno espaço amarelo claro; na área distal, o castanho não chega até a margem externa; mancha redonda escura entre $\mathrm{M}_{1}-\mathrm{M}_{2}$; sobre a metade proximal de $2 \mathrm{~A}$, androcônia oval, de igual tamanho que aquela da face dorsal da asa posterior.

Face ventral da asa posterior com a margem externa crenulada, maior projeção acompanhada pela $\mathrm{CuA}_{1}$; linha submarginal escura, acompanha os desenhos do crenulado da margem externa da asa; faixa, em posição proximal à faixa submarginal de aproximadamente $1 \mathrm{~mm}$ de espessura com escamas brancas, antecedida por outra pouco mais espessa e castanho; faixa basal castanho escuro, desde a metade proximal da margem costal até a metade proximal de 2A; faixa pós-basal, também castanho escuro, da metade distal da célula discal até $3 \mathrm{~A}$, o dobro da largura da basal.

Genitália (Fig. 82 A-E). Unco pouco curvo, com discreta projeção lateral em ponta e com espinhos. Subunco de forma retangular, com extremidade proximal estreita; extremidade distal serrilhada e face externa com inúmeros espinhos. Valva projetada para além da extremidade distal do unco; extremidade distal da valva com espinho subapical projetado dorsalmente e anterior a esse outra projeção, que se expande internamente com várias projeções em ponta. Projeção anterior do saco, quatro vezes mais longa que larga. Juxta, em vista ventral, em forma de $\mathrm{V}$ expandido, com borda distal serrilhada.

Fêmea. Desconhecida.

Discussão. A coloração castanho avermelhado na face dorsal e o amarelo na face ventral de ambas as asas e a asa posterior com a faixa pós-basal mais larga que a basal caracterizam a subespécie.

Distribuição espacial (Fig. 85). Peru, Junín: Rio Perené, Chanchamayo, La Merced, San Ramon. BolíviA, Santa Cruz: Buenavista (Ichilo, Rio Juntas).

Distribuição temporal. Entre o material estudado, os adultos voam de agosto a novembro.

\section{Etologia. Desconhecida}

Planta hospedeira e imaturos. Desconhecidos, mas acredita-se que devam alimentar-se de Poaceae.

Material estudado. Peru, Junín: Rio Perené, 300-800m, 5 machos, IXXI.1987, Tello leg. (OM); Chanchamayo, 4 machos, sem data e 1 macho de VIII.1920 (BMNH); Chanchamayo, La Merced, 2 machos, XI.1904, Schunke leg., 3 machos, X-XI.1919, Watkins leg. (BMNH); San Ramon, 3 machos, X.1903, Watkins leg. (BMNH). BolíviA, Santa Cruz: Buenavista, Ichilo, 1 macho (UFPC), Buenavista, Rio Juntas, 1000 m, 2 machos, 1890, Garlepp leg. (UFPC). 

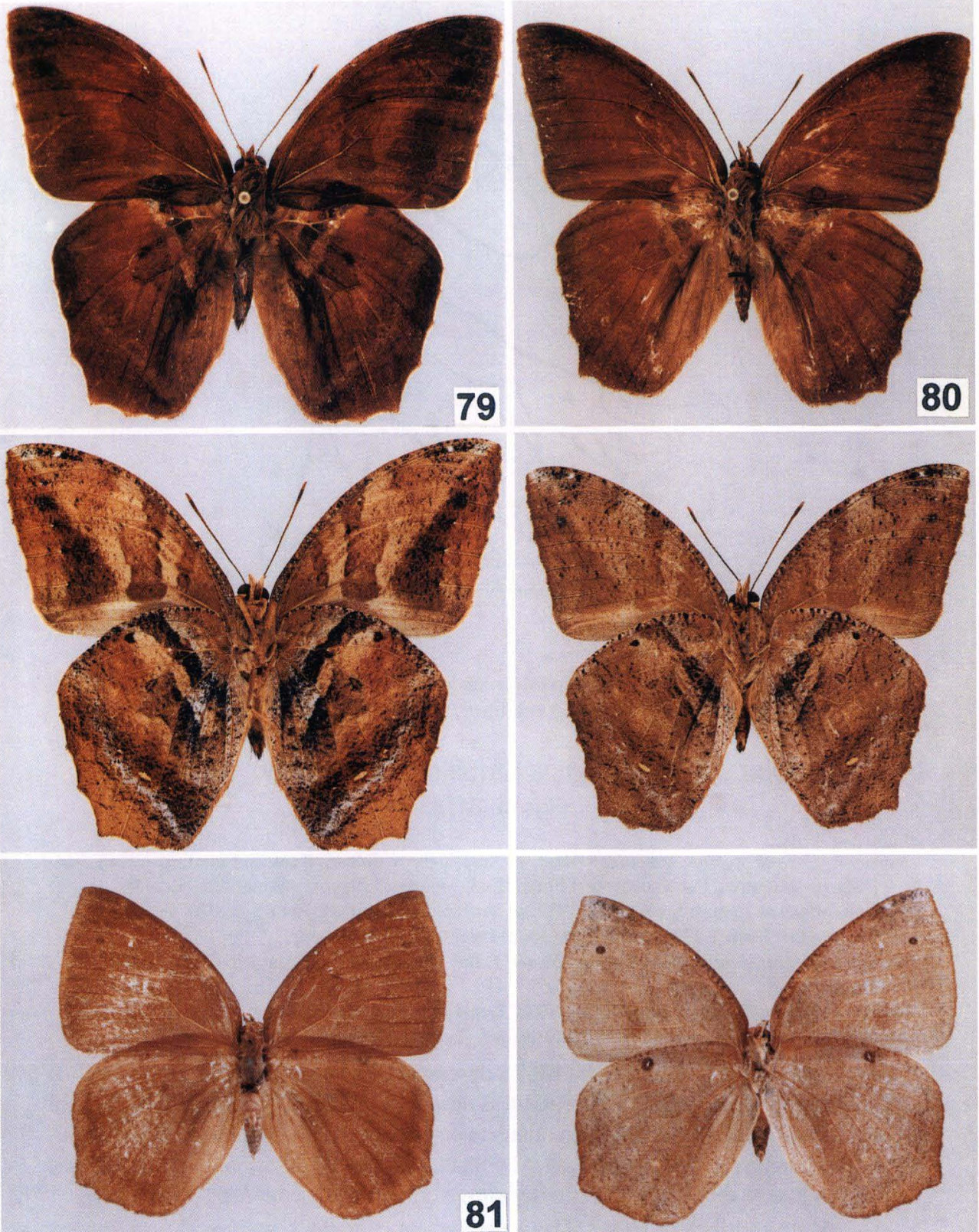

Figs 79-81. (79) Narope syllabus syllabus, macho, vistas dorsal e ventral; (80-81) Narope syllabus stygius: (80) macho, vistas dorsal e ventral; (81) fêmea, vistas dorsal e ventral. 


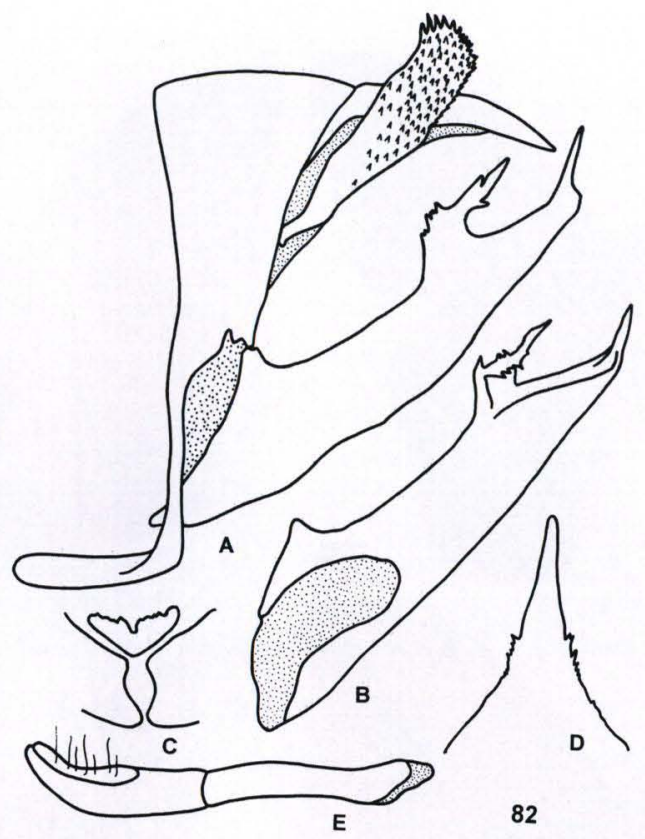

Fig. 82. Narope syllabus syllabus, genitália masculina: (A) vista lateral, (B) valva, vista lateral interna, (C) juxta, vista ventral, (D) tegume/unco, vista dorsal, (E) edeago, vista lateral.

\section{Narope syllabus stygius Staudinger, ssp. rev., comb. $\mathbf{n}$. Figs $80-81,83-85$}

Narope cyllastros stygius Staudinger, 1887, in Staudinger \& Schatz. Exot. Schmett. 1, p. 218; uma fêmea [holótipo], Fonteboa, [recte Fonte Boa], Amazonas superior, [Amazonas, Brasil]. Narope cyllastros stygius; Fruhstorfer, 1912, in Seitz. Gross-Schmett. Erde 5, p. 328; sist., dg. Narope stygius; Stichel, 1916. Neue Beitr. syst. Insektenk. 1: 7; sist., dg.

Narope cyllastros stygius; Miranda-Ribeiro, 1931. Bol. Mus. Nac., Rio de Janeiro, 7 (1): 38; err. ident.; $\mathrm{dg}$.

Narope cyllastros forma stygius; Stichel, 1932. Lepidopteorum Cat. Pars: 51, p. 15; sist., dg. Narope syllabus; Robbins et al., 1996, in Wilson \& Sandoval. Manu, p. 229; dg.

Histórico. STAUDINGER (1887) descreveu stygius como espécie, já que o exemplar que dispunha não apresentava as mesmas características que cyllastros, com quem comparou. STICHEL (1932) considera como forma de cyllastros. Considerandose a distribuição espacial, diferenças já apontadas quando da descrição original e outras aqui levantadas, revalidamos a subespécie e a combinamos com Narope syllabus.

Material tipo. O HOLÓTIPO de Narope cyllastros stygius, é uma fêmea, com as seguintes etiquetas: /Narope not cyllastrus [sic] but see Hewitson /Origin./ Fonteboa Hhl/ I'. n. G. desid/ HOLOTYPE/ Narope syllabus stygius Staudinger, 1887, Holotype, M.M. Casagrande det. 2002/, encontra-se no "Zoologisches Museum der Humboldt Universität", Berlin, Alemanha. 
Diagnose. Face dorsal das asas anterior e posterior castanho escuro ferrugíneo com margem externa escura e franja marginal de escamas claras. Face ventral de ambas as asas bege com faixas e manchas castanho. Nas asas posteriores faixa pó-basal mais estreita que a basal.

Descrição. Macho (Figs 80, 83). Asa anterior: comprimento da margem costal - 33 a $34 \mathrm{~mm}$; margem externa - $24 \mathrm{~mm}$; largura da asa - $22 \mathrm{~mm}$. Asa posterior: comprimento da margem costal $-23 \mathrm{~mm}$; margem externa $-25 \mathrm{~mm}$; maior comprimento $-28 \mathrm{~mm}$.

Cabeça e apêndices, tórax e abdome, castanho escuro.

Asas anterior e posterior na face dorsal castanho escuro ferrugíneo; margem externa com coloração pouco mais escura; androcônia oval, de tamanho médio, creme, pouco além da bifurcação Rs-M1, sobre Rs.

Face ventral em ambas as asas bege. $\mathrm{Na}$ asa anterior, do ápice até pouco antes do meio de $2 \mathrm{~A}$, faixa diagonal imaginária definindo as áreas distal com escamas castanho e a proximal com escamas bege; na proximal, praticamente desde a base até a metade da célula discal castanho claro, incluindo a faixa basal e a pós-basal separada dessa por pequeno espaço bege; na área distal, o castanho não chega até a margem externa; mancha redonda escura com escamas bege no centro, entre $\mathrm{M}_{1}-\mathrm{M}_{2}$; sobre a metade proximal de $2 \mathrm{~A}$, androcônia de forma oval com escamas creme, de igual tamanho que aquela da face dorsal da asa posterior.

Face ventral da asa posterior com a margem externa crenulada, maior projeção acompanhada pela $\mathrm{CuA}_{1}$; linha submarginal escura acompanha os desenhos do crenulado da margem externa da asa; faixa em posição proximal à subapical de aproximadamente $1 \mathrm{~mm}$ de espessura com escamas brancas, mais larga além de $\mathrm{M}_{2}$, antecedida por outra faixa pouco mais espessa e castanho; entre $\mathrm{Sc}+\mathrm{R}_{1}$-Rs, logo após o início da faixa basal, mancha alongada formada por escamas escuras seguida por outras manchas pequenas e bege, distribuídas nos espaços entre as veias seguintes em semicírculo e acompanhando o contorno da asa; faixa basal castanho escuro, desde a margem costal até o meio de $2 \mathrm{~A}$; faixa pós-basal, castanho claro de contornos pouco evidentes, da metade distal da célula discal até $3 \mathrm{~A}$, mais estreita que a basal.

Genitália (Fig. 83A-E). Subunco de forma retangular, com extremidade proximal estreita; extremidade distal alargada e serrilhada; face externa com inúmeros espinhos esclerotinizados. Juxta, em vista ventral, em forma de $\mathrm{V}$ expandido.

Fêmea (Figs 81 e 84). Asa anterior: comprimento da margem costal - $31 \mathrm{~mm}$; margem externa $-22 \mathrm{~mm}$; largura da asa $-22 \mathrm{~mm}$. Asa posterior: comprimento da margem costal $-23 \mathrm{~mm}$; margem externa $-21 \mathrm{~mm}$; maior comprimento $-26 \mathrm{~mm}$.

Cabeça e palpo, castanho claro.

Face dorsal das asas anterior e posterior castanho claro e como nos machos, sem manchas ou faixas.

Face ventral mais clara. Pequenas linhas formadas por escamas escuras se distribuem por toda a superfície ventral. No terço distal da asa anterior, entre $M_{1}-M_{2}$, mancha circular de escamas escuras com escamas creme no centro. $\mathrm{Na}$ asa posterior mancha arredonda formada por escamas escuras, entre $\mathrm{Sc}+\mathrm{R}_{1}$ e Rs, com escamas creme distribuídas no centro de forma alongada. Margem externa crenulada e projetada em $\mathrm{M}_{3}$. 


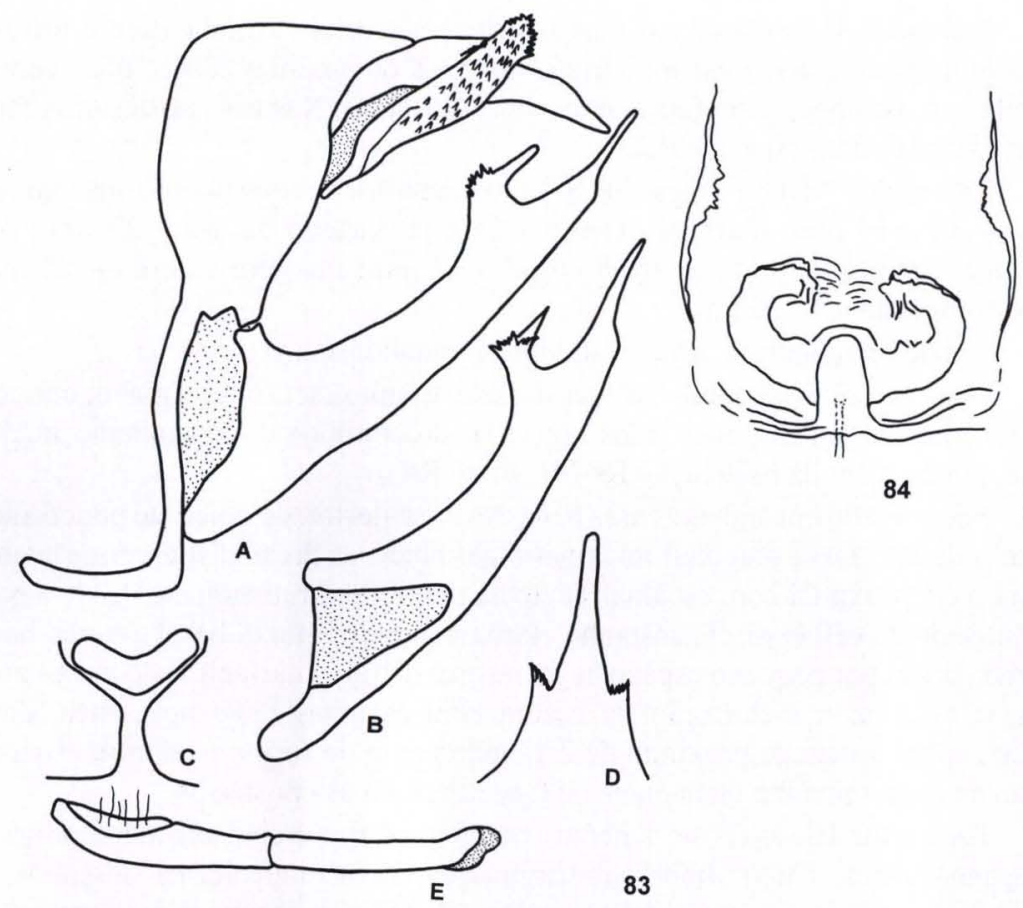

Figs 83-84. Narope syllabus stygius. (83) Genitália masculina: (A) vista lateral, (B) valva, vista lateral interna, (C) juxta, vista ventral, (D) tegume/unco, vista dorsal, (E) edeago, vista lateral; (84) genitália feminina, vista ventral.

Genitália (Fig. 84). Lamela pós-vaginal com braços projetados e convergindo látero-distalmente. Lamela ante-vaginal projetada sobre a parte central da pós-vaginal, com extremidade distal arredondada.

Discussão. A coloração bege na face ventral das asas anteriores e posteriores e a faixa pós-basal na asa posterior, mais estreita que a basal, caracterizam a subespécie. Diferencia-se de $N$. syllabus syllabus pela nuance pálida nos desenhos da face ventral de ambas as asas e pelas diferenças no tamanho da projeção anterior do saco e forma do subunco. A fêmea, muitas vezes, confundida com fêmea Narope cyllastros é facilmente diferenciada desta pela presença da mancha escura no terço distal da face ventral da asa anterior.

Distribuição espacial (Fig. 85). PERU, Madre de Dios: Parque Manu, Pakitza. Brasil, Amazonas: Rio Madeira; Pará: Fonteboa, Óbidos; Rondônia: Jarú, Rio Jamary; Mato Grosso: Cáceres (Salto do Céu).

Distribuição temporal. Entre o material estudado, os adultos voam nos meses de junho à setembro.

Etologia. Machos são atraídos para armadilhas com iscas de frutas em decomposição. 


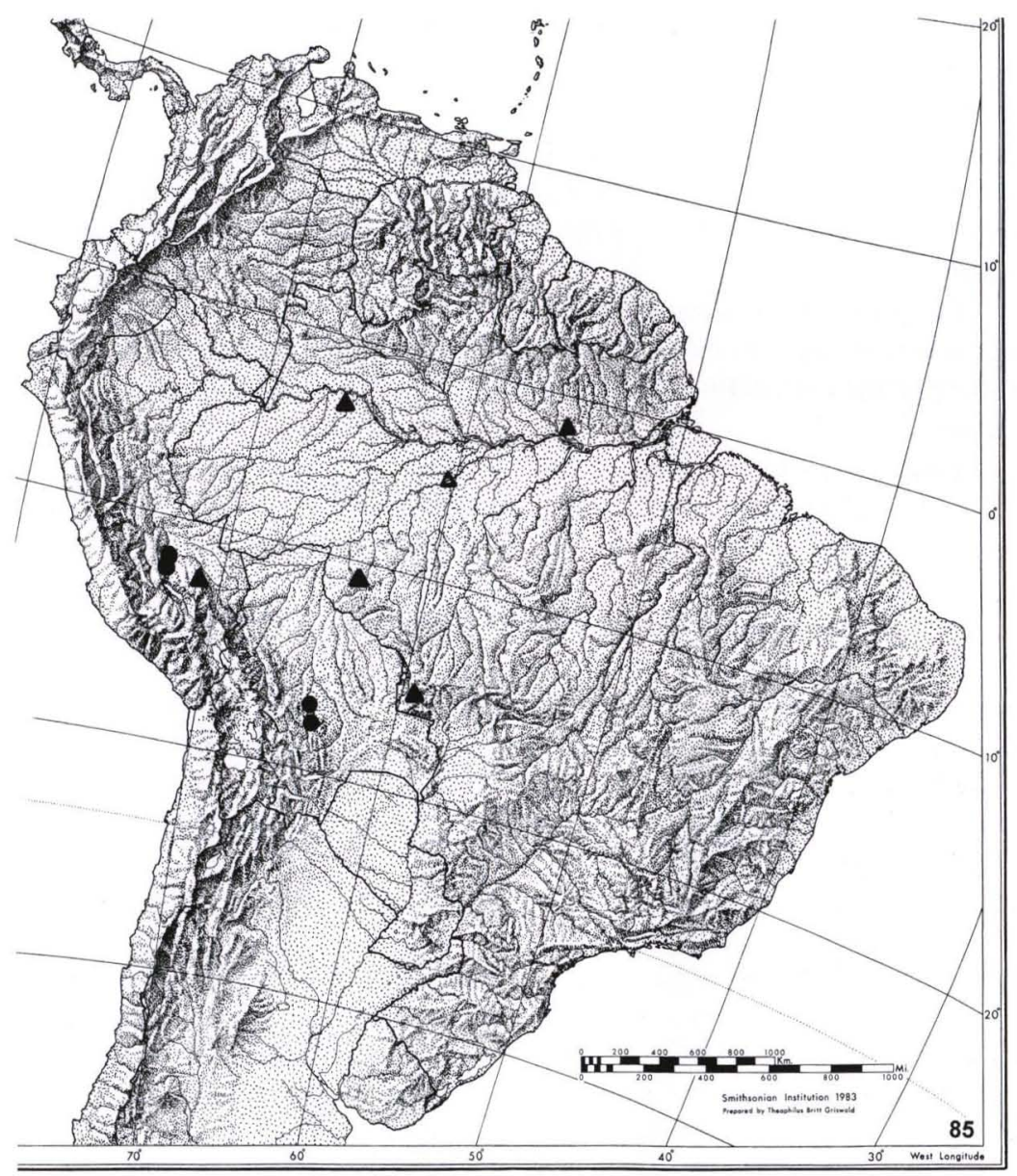

Fig. 85. Narope syllabus, distribuição espacial. (•) Narope syllabus syllabus, (A) Narope syllabus stygius.

Planta hospedeira e imaturos. Desconhecidos, mas acredita-se que devam alimentar-se de Poaceae.

Etimologia. Desconhecida

Material estudado. Peru, Madre de Dios: Pakitza, 3 machos, 27.IX 20.X.1991, 340 m, Casagrande \& Mielke leg. (UFPC) (MHNL). BRASIL, Amazonas: Rio Madeira, 1 macho (MNRJ); Pará: Fonteboa, 1 fêmea (ZMHB), 1 fêmea, Óbidos VI.1966, DZ 4819 (UFPC); Rondônia: Jarú, 4 machos, (4) 5.VIII.1975 e (1) 8.IX.1976, Brown leg. (UFPC), Rio Jamari, 1 macho, 4-12.IX.1977, Gifford \& Negretti leg. DZ 4816 (UFPC), 2 machos (UFPC); Mato Grosso, Cáceres, Salto do Céu, 1 macho, 7.VI.1971, Brown leg. (KB). 


\section{Narope ybyra Casagrande, sp. $\mathbf{n}$.}

\section{Figs 75,78 e 86}

Material tipo. HOLÓTIPO na Coleção de Entomologia do Museu Nacional, Rio de Janeiro, Rio de Janeiro, Brasil, com as seguintes etiquetas: /HOLOTYPE/ Bolívia/ MN 19003/ Col. Julius Arp/ Narope ybyra Casagrande, Holotype, M.M. Casagrande det. 2002/.

Diagnose. Face dorsal das asas anterior e posterior ferrugíneo claro. Margem externa da asa posterior de contorno arredondado com suave crenulado. Tegume projetado distalmente sobre o unco. Subunco retorcido e com inúmeros espinhos.

Descrição. Macho (Figs 75-86). Asa anterior: comprimento da margem costal $-33 \mathrm{~mm}$; margem externa $-23 \mathrm{~mm}$; largura da asa $-21 \mathrm{~mm}$. Asa posterior: comprimento da margem costal - $22 \mathrm{~mm}$; margem externa $-25 \mathrm{~mm}$; maior comprimento $-26 \mathrm{~mm}$.

Cabeça e apêndices, tórax e abdome ferrugíneo.

Face dorsal das asas anterior e posterior ferrugíneo claro. Ápice da asa anterior formando um semicírculo de escamas castanho escuro, desde a base de $\mathrm{R}_{4}-\mathrm{R}_{5}$ até $\mathrm{M}_{2}$. Na asa posterior, androcônia oval, de tamanho médio, creme, pouco além da bifurcação Rs-M1, sobre Rs; linha marginal com aproximadamente $1 \mathrm{~mm}$ de espessura e de ferrugíneo pouco mais acentuado que o restante da asa.

Face ventral de ambas as asas castanho com inúmeros aglomerados de escamas mais escuras em forma de pequenos pontos ou linhas disformes. Na asa anterior, do ápice ao meio de $2 \mathrm{~A}$, com faixa diagonal de aproximadamente $1 \mathrm{~mm}$ de largura, com escamas difusas mais claras; faixa basal dentro da célula discal e outra, pós-basal, três a quatro vezes mais larga que a basal, desde a margem costal, passando sobre, as discocelulares, até a base de $\mathrm{M}_{3}$, posteriormente além da célula discal até o meio de $2 \mathrm{~A}$. Sobre a metade proximal de $2 \mathrm{~A}$, androcônia de forma oval, creme, pouco menor que aquela da face dorsal da asa posterior.

Face ventral da asa posterior, entre $\mathrm{Sc}+\mathrm{R}_{1}-\mathrm{Rs}$, no meio da margem costal, ponto de escamas escuras com centro branco, o primeiro de uma série de pontos que ocupam os espaços entre as veias longitudinais subsequentes, de cor creme e em semicírculo acompanhando o contorno convexo da asa; sem reflexos violáceos ou prata. Faixas basal e pós-basal, castanho escuro avermelhado, paralelas desde a metade proximal da margem costal até a metade proximal de $2 \mathrm{~A}$.

Genitália (Fig. 86 A-E). Tegume com a margem lateral fortemente retraída. Unco curvo e com projeção lateral em ponta, de contorno serrilhado. Subunco de forma retangular, estreito na base, alargando posteriormente e pouco além da metade, retorcido e falcado, terminando de forma rombuda; toda a área retorcida com espinhos. Valva estreita, não projetada para além do unco; extremidade distal com duas pontas, a anterior voltada para o dorso, de borda serrilhada e internamente revestida de espinhos e a posterior dirigida para a porção distal, pouco pronunciada. Juxta, em vista ventral, com forma de triângulo invertido.

Fêmea. Desconhecida. 

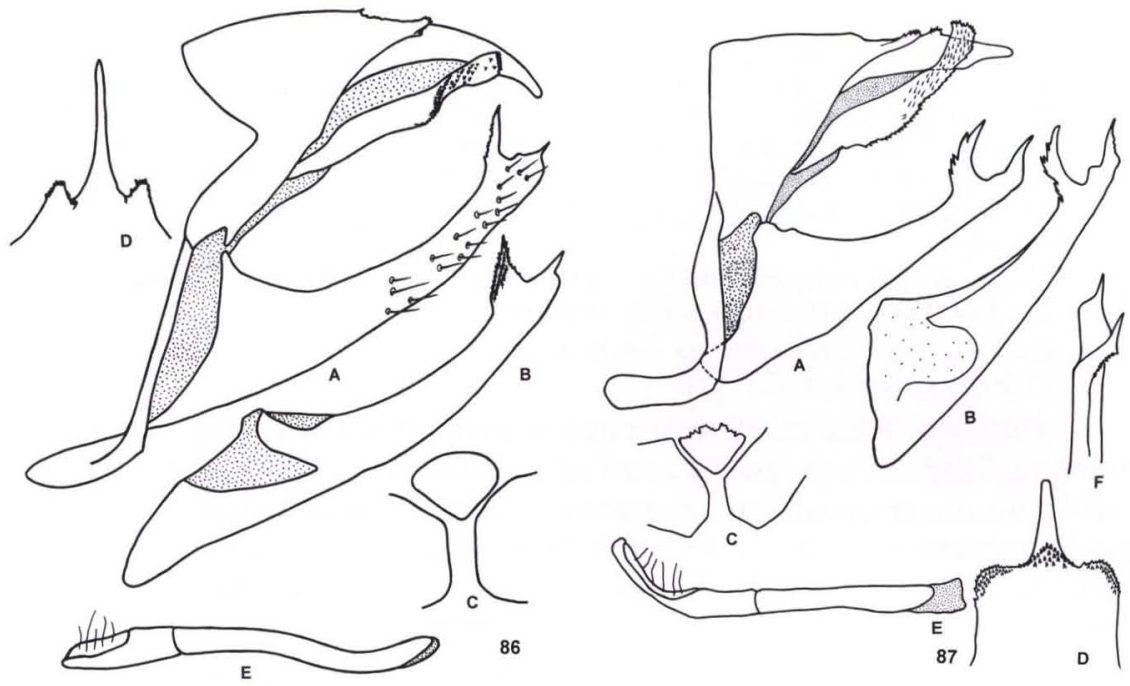

Figs 86-87. Genitália masculina: (A) vista lateral, $(B)$ valva, vista lateral interna, $(C)$ juxta, vista ventral, (D) tegume/unco, vista dorsal, (E) edeago, vista lateral, (F) ápice da valva; (86) Narope ybyra sp. n., holótipo; (87) Narope marmorata.

Discussão. A margem externa da asa posterior, quase arredondada, e os detalhes da genitália masculina como a margem lateral do tegume fortemente retraída, o subunco retorcido, valva estreita e a forma da juxta em triângulo invertido caracterizam a espécie.

Distribuição espacial (Fig. 78). BoLívIA.

Distribuição temporal. Desconhecida

Etologia. Desconhecida

Planta hospedeira e imaturos. Desconhecidos, mas acredita-se que devam alimentar-se de Poaceae.

Etimologia. Tupi: ybyra que significa - írmão mais novo

Material estudado. O holótipo, único exemplar conhecido.

\section{Narope anartes Hewitson, 1874}

Figs 88-89, 91-92 e 98

Narope anartes Hewitson, 1874. Descr. Butt., p. 9; Bolívia.- Kirby, 1877. Syn. Cat. Diurn. Lep., Suppl., p. 717; cat.- Staudinger, 1887, in Staudinger \& Schatz. Exot. Schmett. 1, p. 218; sist., dg.- Godman, 1901, in Godman \& Salvin. Biol. Centr.- Amer., Lep. Rhop. 2, p. 666; syn.: sarastro; sist., dg.- Stichel, 1904, in Wytsman. Gen. Ins. 20, p. 15; syn.: syllabus, marmorata; cat., dg.- Stichel, 1909. Tierreich 25, p. 42, 46, figs (venação), 12 (macho d, v); syn.: syllabus, marmorata; sist., cat., dg.- Fruhstorfer, 1912, in Seitz, Gross-Schmett. Erde 5, p. 329; sist., dg.Stichel, 1916. Neue Beitr. syst. Insektenkunde 1: 7; sist., dg.- Stichel, 1932. Lep. Cat. 51, p. 15; cat.- Casagrande, 1996. Revta bras. Zool. 12:

686, fig. 34 (gen. masc.); sist.- D’Abrera, 1987. Butt. Neotrop. Reg. 3, p. 392, figs (macho d, v, fêmea d); sist., dg.- Velez \& Salazar, 1991. Marip. Colomb., p. 157, Fig. (fêmea d); dg.

Narope sarastro Staudinger, 1886, in Staudinger \& Schatz. Exot. Schmett. 1, pl. 76 (macho d, v).- 
Staudinger, 1887, in Staudinger \& Schatz. Exot. Schmett. 1, p. 218; 1 macho [holótipo], Valle do Cauca, [Colômbia]; coleção Staudinger--Stichel, 1904. Ins.- Börse 21: 21; fêmea.- Stichel, 1904, in Wytsman. Gen. Ins. 20, p. 15; cat., dg.-Stichel, 1909. Tierreich 25, p. 42, 45, fig. 10 (venação); sist., cat., dg.- Fruhstorfer, 1912; in Seitz Gross-Schmett. Erde 5, p. 329; sist., dg.-Stichel, 1916. Neue Beitr. syst. Insektenk. 1: 7; sist.- Fassl, 1918. Ent. Rdsch. 35: 31; dg.- Hering \& Hopp, 1925. Dtsch. ent. Ztschr. Iris 39: 193; dg.- Smart, 1976. Enc. Butt. World, p. 240, fig. 8 (d); dg.; syn. $\mathbf{n}$.

Narope sarastro disyllus Fruhstorfer, 1912, in Seitz. Gross-Schmett. Erde 5, p. 329; Huancabamba, [Cajamarca], Peru, 1500m.- Lamas, 1969. Biota, Peru, 7: 290; dg.; syn. n.

Narope anartes anartes; Stichel, 1932. Lep. Cat. 51: 15; syn.: f. disyllus, f. marmorata; cat., dg.-Lamas, 1985. Rev. peruana Ent. 27: 70; dg.

Histórico. Todas as referências que seguem após a descrição original dizem respeito à distribuição geográfica e catálogo. STAUDINGER (1887), quando descreveu $N$. sarastro, já supunha que era apenas uma forma local de $N$. anartes, caso não fosse um sinônimo. STICHEL (1932) menciona Narope sarastro disyllus como uma forma de Narope anartes. As descrições originais de Narope sarastro e Narope sarastro disyllus idicam que ambas são sinônimos de $N$. anartes.

Material tipo. A descrição de Narope anartes baseia-se em um número não definido de exemplares. No "The Natural History Museum" Londres, Inglaterra, foi encontrado um síntipo macho, aqui designado LECTÓTIPO, com o objetivo de garantir a adequada identificação da espécie, com as seguintes etiquetas: /Type/ BOLÍVIA, Hewitson Coll. 79 - 69, Narope anartes Hewitson/ B.M. N R.H. 6116, Narope anartes Hew., macho/. /LECTOTYPE/ Narope anartes Hewitson, 1874, Lectotype, M.M. Casagrande det. 2002/.

O HOLÓTIPO de Narope sarastro está depositado na coleção do "Zoologisches Museum der Humboldt Universitat", Berlim, Alemanha, com as seguintes etiquetas: /Origin./ Cauca Patino/ sarastro Stgr Type/ abgebildet/.

A descrição de Narope sarastro disyllus não menciona o número de exemplares. Nas coleções estudadas, onde estão outros tipos de Fruhstorfer, não foi encontrado nenhum sintipo.

Diagnose. Face dorsal das asas anterior e posterior castanho ferrugíneo. Asa posterior pouco mais escura que a anterior, com faixa marginal ferrugíneo intenso e margem externa com suave crenulado. Na fêmea, mancha amarelo intenso na asa anterior.

Descrição. Macho (Figs 88 e 91). Asa anterior: comprimento da margem costal - 33 a $37 \mathrm{~mm}$; margem externa - 23 a $26 \mathrm{~mm}$; largura da asa -22 a $25 \mathrm{~mm}$. Asa posterior: comprimento da margem costal -23 a $25 \mathrm{~mm}$; margem externa -24 a $27 \mathrm{~mm}$; maior comprimento da asa - 27 a $29 \mathrm{~mm}$.

Cabeça, tórax e abdome castanho ferrugíneo. Antenas ferrugíneas.

Face dorsal das asas anterior e posterior castanho ferrugíneo. Na asa anterior, sobre a base de $\mathrm{R}_{4}-\mathrm{R}_{5}$ e formando um semicírculo até $\mathrm{M}_{2}$, escamas enegrecidas com reflexos violeta. Na célula discal da asa anterior e além desta, o ferrugíneo é mais intenso. $\mathrm{Na}$ asa posterior o ferrugíneo é menos intenso que na anterior, exceto na faixa marginal de aproximadamente $1 \mathrm{~mm}$ de largura, onde a cor é mais acentuada; margem externa crenulada, maior projeção acompanhada pela $\mathrm{CuA}_{1}$; androcônia oval, de tamanho médio, creme, pouco além da base da bifurcação Rs-M1, sobre Rs. 

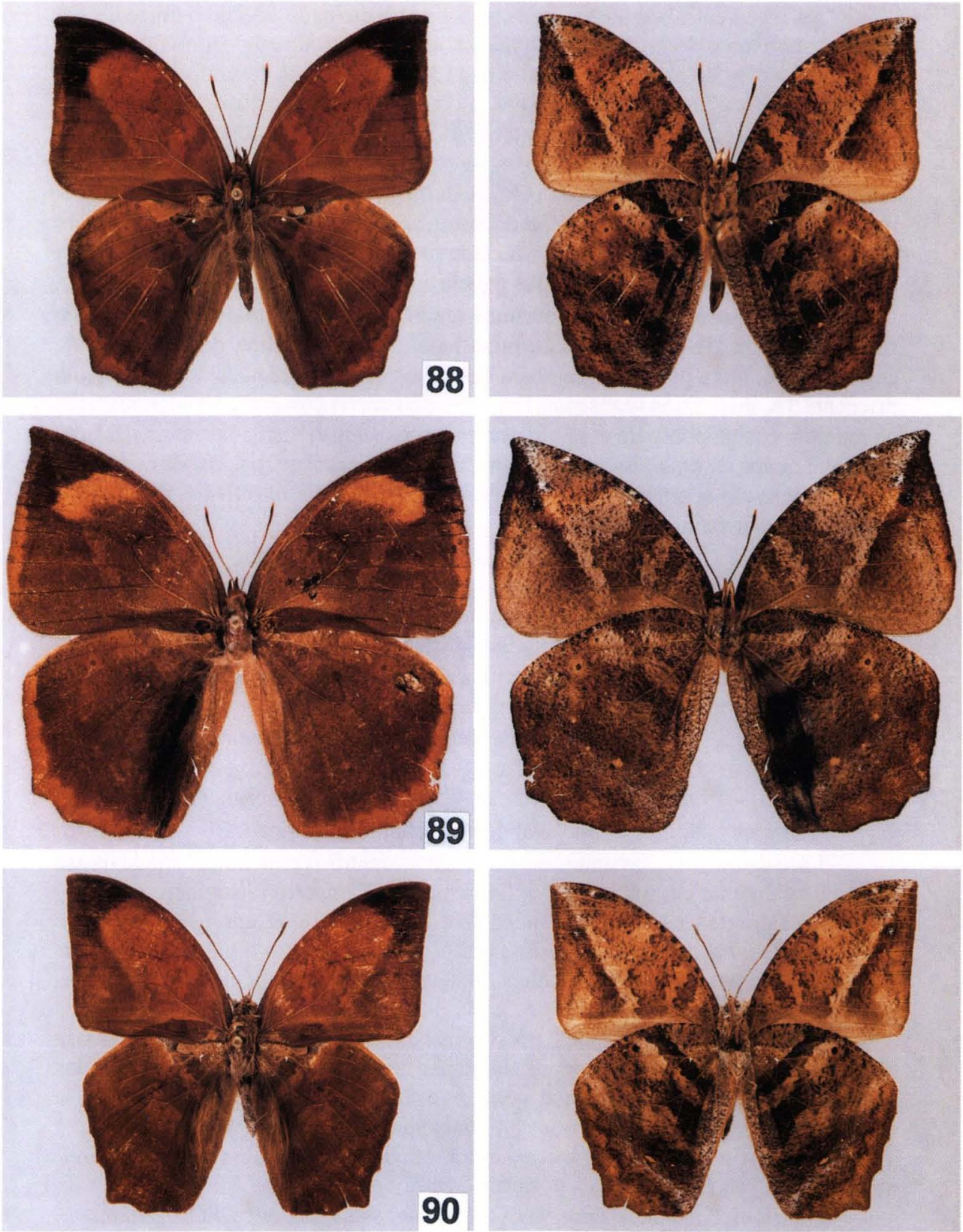

90

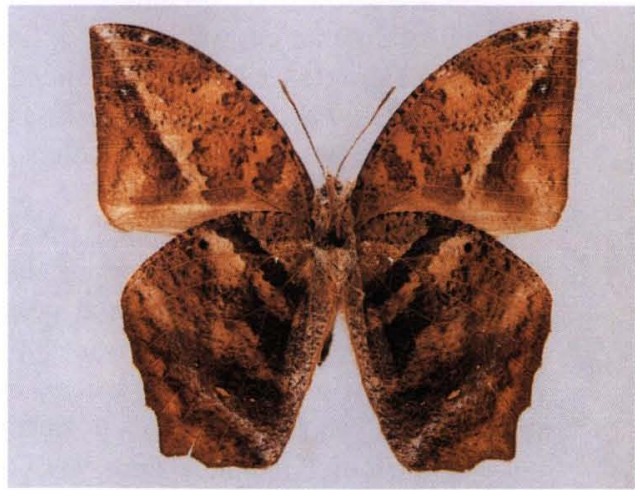

Figs 88-90. (88-89) Narope anartes: (88) macho, vistas dorsal e ventral; (89) fêmea: vistas dorsal e ventral; (90) Narope marmorata, macho, vistas dorsal e ventral. 
$\mathrm{Na}$ face ventral de ambas as asas, bege avermelhado. Desde o ápice da asa anterior até o meio de $2 \mathrm{~A}$, faixa diagonal, com aproximadamente $1 \mathrm{~mm}$ de largura, de escamas brancas na região apical e bege avermelhada no restante, dividindo a asa em duas áreas; a distal mais escura, e diminuindo a intensidade da tonalidade conforme se aproxima da margem externa e área proximal mais clara; ponto escuro com escamas claras, logo além da faixa, no espaço $\mathrm{M}_{1}-\mathrm{M}_{2}$; área proximal com duas outras faixas, uma basal dentro da célula e outra pós-basal, esta três a quatro vezes mais larga que a basal, desde a margem costal, passando sobre as discocelulares até $\mathrm{M}_{3}$, e daí até o meio de $2 \mathrm{~A}$; sobre a metade proximal de $2 \mathrm{~A}$, androcônia de forma arredondada, do mesmo tamanho que aquela da face dorsal da asa posterior.

$\mathrm{Na}$ asa posterior com as mesmas tonalidades porém mais intensas; linha submarginal em zig-zag acentuado; faixa basal castanho escuro, desde a margem costal até $2 \mathrm{~A}$; faixa pós-basal, também castanho escuro, da metade distal da célula discal até $3 \mathrm{~A}$, duas a três vezes mais larga que a basal; no espaço $\mathrm{Sc}+\mathrm{R}_{1}-\mathrm{Rs}$, no meio da margem costal, ponto de escamas escuras com centro branco, o primeiro de uma série que ocupa os espaços entre as veias longitudinais subsequentes, de cor creme e em semicirculo acompanhando o contorno convexo da asa; reflexos prateados e violáceos nas áreas mais escuras.

Genitália (Fig. 91A-E). Unco curvo, pouco maior que o tegume, com projeção lateral em ponta e de contorno serrilhado. Subunco de forma retangular e uniforme; metade distal retorcida e com numerosos espinhos; valva estreita e não projetada para além do unco, extremidade distal alarga-se progressivamente, terminando com duas pontas voltadas para cima, sendo a anterior revestida por espinhos. Juxta, em vista ventral, com forma de pera.

Fêmea (Figs 89 e 92). Asa anterior: comprimento da margem costal - 37 mm; margem externa $-27 \mathrm{~mm}$; largura da asa $-26 \mathrm{~mm}$. Asa posterior: comprimento da margem costal - $29 \mathrm{~mm}$; margem externa $-29 \mathrm{~mm}$, maior comprimento - $31 \mathrm{~mm}$.

Cabeça e apêndices, tórax e abdome castanho ferrugíneo.

Face dorsal das asas anterior e posterior castanho avermelhado. Ápice da asa anterior totalmente castanho escuro; linha marginal amarelo ferrugíneo, entre $\mathrm{M}_{2}$ até pouco além de $\mathrm{CuA}_{1}$; larga mancha de escamas amarelas, em meia lua, pouco antes do ápice. Face ventral das asas anterior e posterior com o mesmo padrão de cores, faixas e pontos que nos machos, inclusive na intensidade de tons e reflexos prateados e violáceos.

Genitália (Fig. 92). Lamela pós-vaginal em forma de placa retangular, quase quadrada com depressão no meio da região proximal, formando dois bordos arredondados. Lamela ante-vaginal, pequena e pouco esclerotinizada. Duto da bolsa e bolsa com aproximadamente o mesmo tamanho; corpo da bolsa alongado.

Discussão. As escamas apicais escuras na asa anterior e o castanho ferrugíneo das asas, principalmente na posterior identificam a espécie.

Distribuição espacial (Fig. 98). ColôMBIA, Valle do Cauca. PERU, Huánuco: Tingo Maria, Junín, Rio Perene; Cuzco: San Pedro. BolíviA, Cochabamba: Chapare, Cristal Mayo; La Paz: Coroico.

Distribuição temporal. Entre o material estudado escontrou-se adultos voando em fevereiro e de agosto a novembro. 


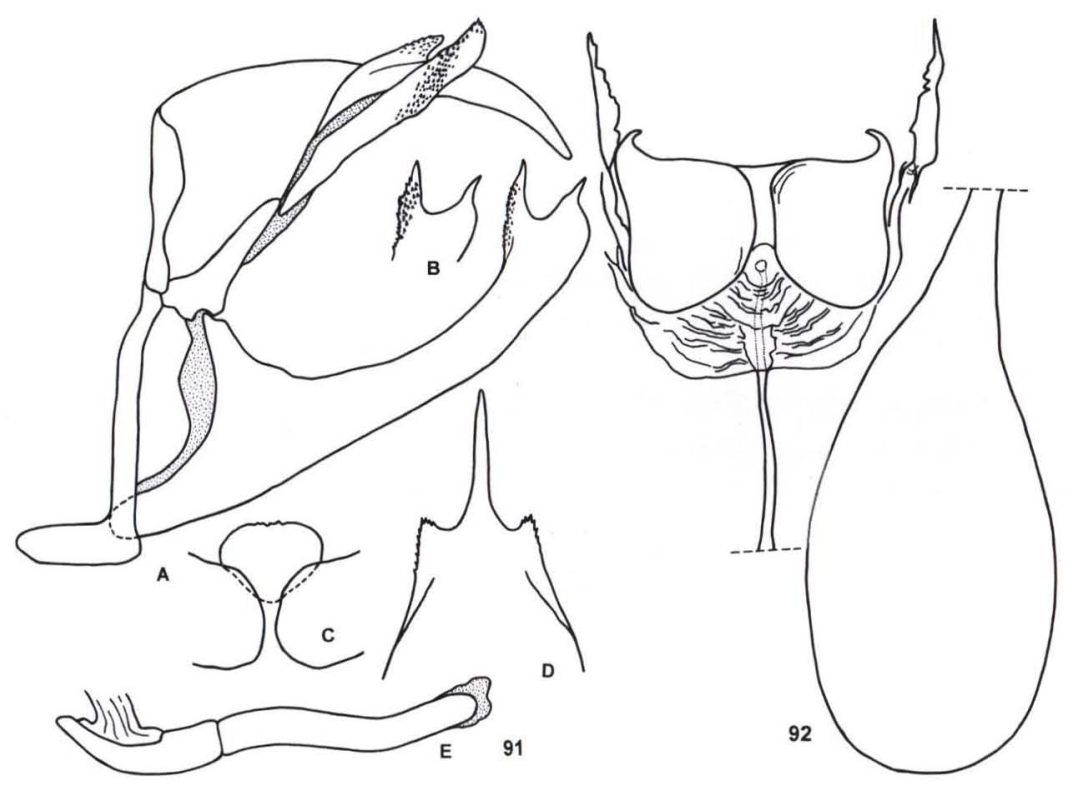

Figs 91-92. Narope anartes. (91) Genitália masculina: (A) vista lateral, (B) valva, vista lateral interna, (C) juxta, vista ventral, (D) tegume/unco, vista dorsal, (E) edeago, vista lateral; (92) genitália feminina, vista ventral.

Etologia. Desconhecida

Planta hospedeira e imaturos. Desconhecidos, mas acredita-se que devam alimentar-se de Poaceae.

Material estudado. Colômbia, Valle do Cauca. Peru, Huánuco: Tingo Maria, Rio Monzon, 1 macho, 11.X.1981, Schunke leg. (OM); Tingo Maria, 700 m, 1 macho, XI.1981, Schunke leg. (OM); Tingo Maria, 2 machos, VIII.1975, Rojas leg. (OM); Tingo Maria, 1 macho, 26.III.1988, Büche leg. (OM); Oeste do Peru, 2 machos (MNRJ). Junín: Rio Perené, 300-800 m, 1 macho, IX - XI, 1987, Tello leg. (OM); Cuzco: San Pedro, Vale do Cosñipata, 1400 m, 2 machos, 5-10. XI. 2001, Mielke leg. (OM). BolíviA, Cochabamba: Chapare, Alto Palmar, 1100m, 2 machos (UFPC) (OM); Cristal Mayo, 600 m, 1 macho, III.1961 (UFPC). La Paz: Coroico, $120 \mathrm{~m}, 1$ macho (MNRJ).

\section{Narope cauca Casagrande, sp. $\mathbf{n}$.}

Figs $93-94$, 96-98

Material tipo. HOLÓTIPO na coleção do "Zoologisches Museum der Humboldt Universität", Berlim, Alemanha, com as seguintes etiquetas: /B.C.A. Lep.Rhop. Narope anartes, Hew. Godman - Salvin Coll. 1919-6/ sarastro Stgr. Cauca Valle Stgr. 881/ Cauca Vall., Colômbia. Ex Staudinger/1 ơ/HOLOTYPE/ Narope cauca Casagrande, 2002, Holotype, M.M. Casagrande det. 2002/. 
ALÓTIPO na Coleção de Entomologia Padre Jesus Santiago Moure, Departamento de Zoologia, Setor de Ciências Biológicas, Universidade federal do Paraná, Brasil, fêmea, com as seguintes etiquetas: /ALLOTYPE/ Columbien. Ex Coll. H. Fruhstorfer/ sarastro Stdgr? Columbi/ DZ 4827/ Narope cauca Casagrande, Allotype, M.M. Casagrande det. 2002/

Diagnose. Face dorsal das asas anterior e posterior castanho claro ferrugíneo. Asa posterior com o ferrugíneo mais intenso, faixa marginal ferrugíneo intenso e margem externa lisa. Na fêmea, mancha ferrugínea de contorno difuso, na asa anterior.

Descrição. Macho (Figs 93 e 96). Asa anterior: comprimento da margem costal - $37 \mathrm{~mm}$; margem externa $-25 \mathrm{~mm}$; largura da asa $-24 \mathrm{~mm}$. Asa posterior: comprimento da margem costal - $25 \mathrm{~mm}$; margem externa - $28 \mathrm{~mm}$; maior comprimeno da asa $-28 \mathrm{~mm}$.

Cabeça, tórax e abdome, castanho claro ferrugíneo. Antenas e palpos ferrugíneo intenso.

Face dorsal das asas anterior e posterior castanho claro ferrugíneo; faixa marginal com aproximadamente $1 \mathrm{~mm}$ de largura, em ferrugíneo quase laranja, na margem externa de ambas as asas, pouco mais evidente e alargando progressivamente em direção ao angulo anal nas posteriores. Na asa anterior, sobre a base de $\mathrm{R}_{4}-\mathrm{R}_{5}$ e formando um semicírculo desde o ápice até o torno, escamas enegrecidas com reflexos violeta. Ápice da asa posterior com escamas enegrecidas de reflexos violeta até pouco além de $\mathrm{M}_{1}$; androcônia oval, de tamanho médio, creme, pouco além da bifurcação Rs-M1, sobre Rs; dentro da célula discal e na base das cubitais e anais escamas castanho sem ferrugíneo.

Face ventral da asa anterior castanho com nuances e faixas castanho ferrugíneo distribuídas da seguinte forma; faixa com $2 \mathrm{~mm}$ de espessura castanho claro, do ápice até o meio da margem interna, na parte distal desta faixa o castanho é mais escuro enquanto que na proximal castanho totalmente claro, e a faixa basal no meio da célula discal e a pós-basal sobre as discocelulares pouco mais escuras e com tons ferrugíneos. No ápice da asa, escamas brancas em pequenas linhas. Sobre a metade proximal de $2 \mathrm{~A}$, androcônia com escamas creme pouco menor que aquela da face dorsal da asa posterior.

$\mathrm{Na}$ face ventral da asa posterior, linha sinuosa submarginal define com o bordo da margem externa da asa uma área castanho ferrugíneo. Faixa basal, diagonal, desde a metade da margem anterior, passando pela base da bifurcação Rs- $\mathrm{M}_{1}$, meio da célula discal até próximo à base de $3 \mathrm{~A}$. Ainda na margem externa, entre $\mathrm{Sc}+\mathrm{R}_{1}-\mathrm{Rs}$, e após o início da faixa, ponto formado por escamas escuras com centro claro, seguido de outros menores, entre as veias subsequentes formando um semicírculo que acompanha o formato convexo da margem externa. O contorno da asa é completamente arredondado, sem crenulados ou projeções. A faixa pós-basal de coloração escura, porém não tão intensa como a basal tem início na dcs e termina próxima de $2 \mathrm{~A}$. Da faixa pós-basal até a linha submarginal várias escamas claras com reflexos prata e violáceo se encaixam entre as escamas castanho ferrugíneo, conferindo à asa reflexo violáceo. 

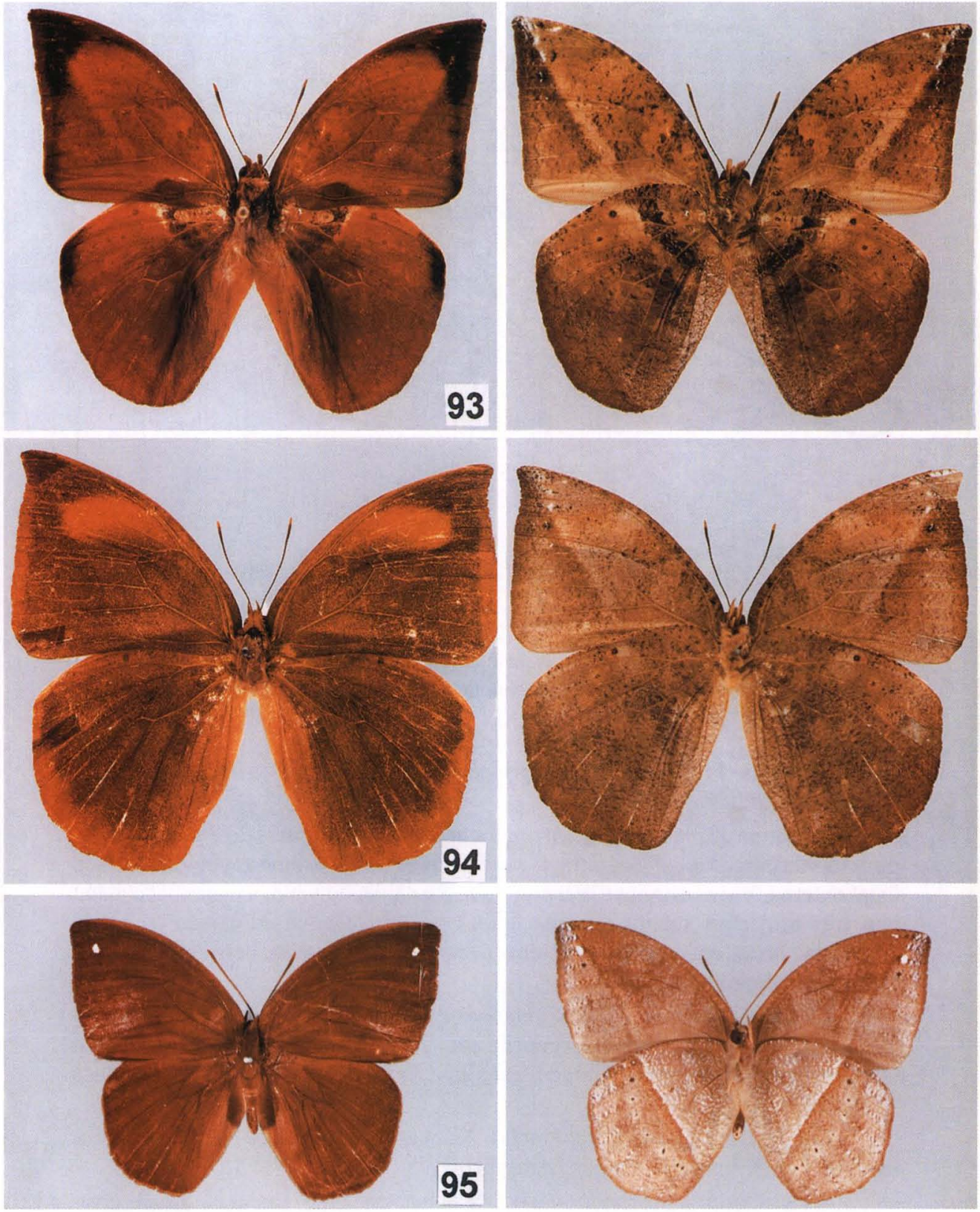

Figs 93-95. (93-94) Narope cauca sp. n.: (93) macho, holótipo, vistas dorsal e ventral; (94) fêmea, alótipo, vistas dorsal e ventral; (95) Narope albopunctum, macho, holótipo, vistas dorsal e ventral. 


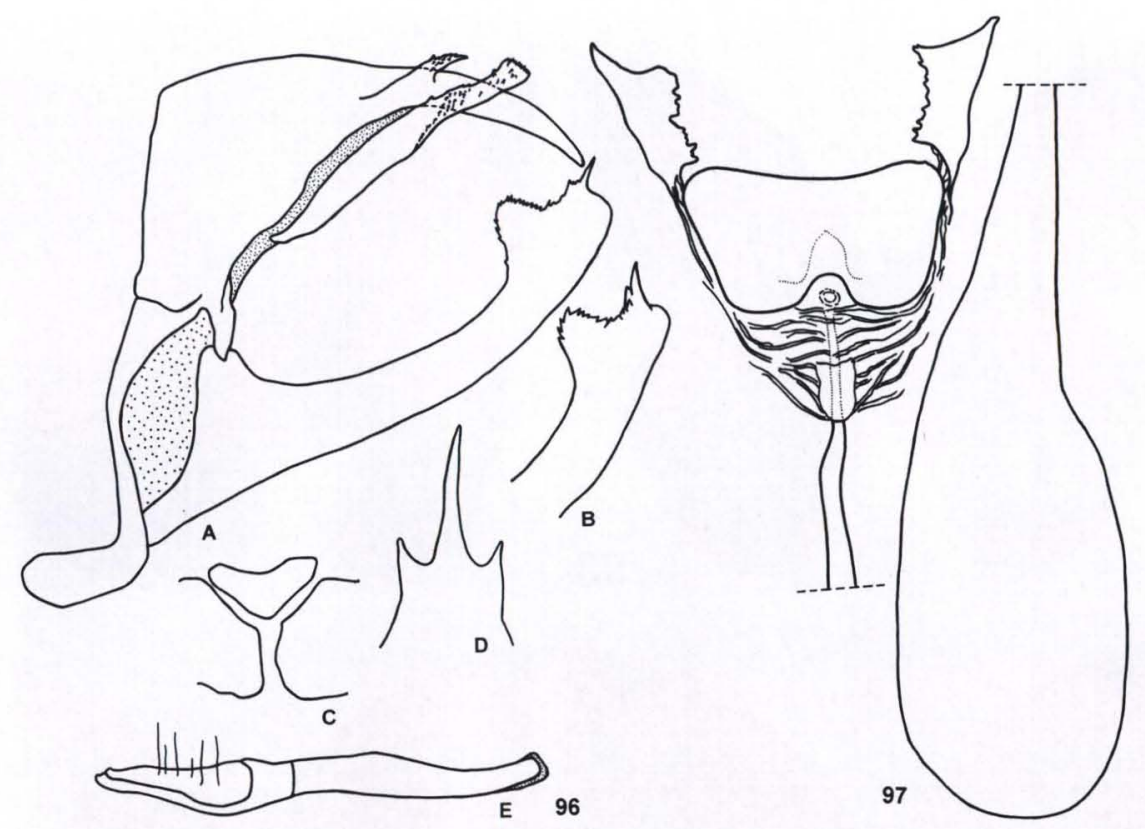

Figs 96-97. Narope cauca sp. n. (96) Genitália masculina: (A) vista lateral, (B) valva, vista lateral interna, (C) juxta, vista ventral, (D) tegume/unco, vista dorsal, (E) edeago, vista lateral; (97) genitália feminina, vista ventral.

Genitália (Fig. 96A-E). Unco pouco curvo, com projeções laterais em ponta e com espinhos; subunco

em forma de placa retangular, maior que a metade da soma do tegume e unco, retorcido na porção mediana, ultrapassando o unco e com espinhos em toda metade distal externa. Valva estreita e não projetada para além do unco; extremidade distal com três projeções subapicais antecedidas por estrutura arredondada de borda serrilhada. Juxta, em vista ventral, em forma de $\mathrm{V}$ expandido, com porção distal suavemente deprimida.

Fêmea (Figs 94 e 97). Asa anterior: comprimento da margem costal - 39 $\mathrm{mm}$; margem externa $-27 \mathrm{~mm}$; largura da asa $-26 \mathrm{~mm}$. Asa posterior: comprimento da margem costal $-29 \mathrm{~mm}$; margem externa $-30 \mathrm{~mm}$; maior comprimento da asa $-32 \mathrm{~mm}$.

Cabeça, tórax e abdome castanho. Antenas ferrugíneas com escamas claras nos flagelômeros apicais. Palpos ferrugíneos.

Asas anterior e posterior com a face dorsal castanho. Linha marginal ferrugínea, de aproximadamente $1 \mathrm{~mm}$ de largura na asa anterior e aumentando a largura progressivamente na asa posterior até atingir aproximadamente $3 \mathrm{~mm}$ de largura no ângulo anal. $\mathrm{Na}$ asa anterior, além da célula discal, antes do ápice e acima de $\mathrm{M}_{2}$ mancha laranja ferrugíneo. 


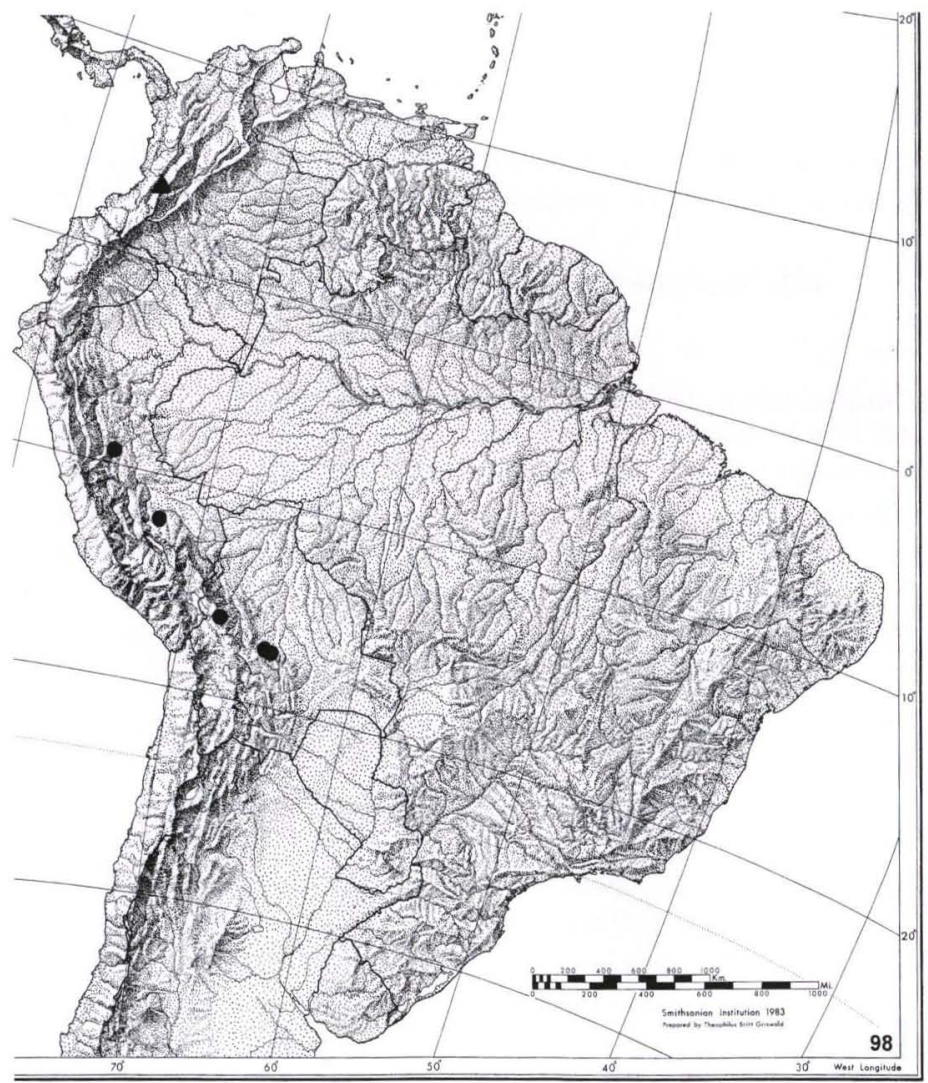

Fig. 98. Distribuição espacial. (•) Narope anartes, (A) Narope cauca sp. n.

Face ventral de ambas as asas mais clara que a face dorsal, com inúmeros conjuntos de escamas escuras. Na asa anterior, como nos machos, faixa diagonal do ápice até a metade de $2 \mathrm{~A}$. Na asa posterior, ponto escuro bem marcado na parte média entre $\mathrm{Sc}+\mathrm{R}_{1}$-Rs. Como nos machos, porém em menor intensidade, reflexos prata e violáceos presentes.

Genitália (Fig. 97). Lamela pós-vaginal com a forma de placa retangular esclerotinizada, com suave depressão mediana anterior. Lamela ante-vaginal pequena e suavemente esclerotinizada. Duto da bolsa pouco menor que a bolsa; bolsa alongada.

Discussão. A cor laranja ferrugíneo mais intenso, a margem externa da asa posterior lisa no macho e a mancha ferrugínea dispersa na asa anterior da fêmea e o ápice desprovido de escamas escuras, caracterizam $N$. cauca $\mathbf{s p .} \mathbf{n}$.

Distribuição espacial (Fig. 98). ColôMBIA: Valle do Cauca. 
Distribuição temporal. Desconhecida.

Etologia. Desconhecida.

Planta hospedeira e imaturos. Desconhecidos, mas acredita-se que devam alimentar-se de Poaceae.

Etimologia. O nome é alusivo à localidade tipo, Valle do Cauca.

Material estudado. Os exemplares citados no item Material tipo.

\section{Narope marmorata Schaus, 1902, stat. rev.}

Figs 87,90 e 99

Narope marmorata Schaus, 1902. Proc. U.S. Nat. Mus. 24: 390; tipos $n^{\circ}$ 5.878, Bolívia; USNM.-

Stichel, 1916. Neue Beitr. syst. Insektenk. 1: 7; sist.

Narope anartes forma marmorata; Stichel, 1932. Lep. Cat. 51, p.16.

Histórico. Após a descrição da espécie por SCHAUs (1902) foi sinonimizada com Narope anartes por STICHEL (1904) e mencionada como Narope anartes $\mathrm{f}$. marmorata também por STICHEL (1932).

Material tipo. No "National Museum of Natural History", Smithsonian Institution, Washington, Estados Unidos, foram encontrados dois síntipos com o mesmo número. O exemplar, macho, mencionado na descrição original como possuindo "wings brown, the veins paler; also the basal and anterior portion of primaries to the dark violaceous brown apical portion which does not reach vein 4 on the outer margin." é aqui designado como LECTÓTIPO, com o objetivo de garantir a adequada identificação da espécie, com as seguintes etiquetas: /Narope marmorata type Schaus/ Bolívia/ Collection W. Schaus/ Type N ${ }^{\circ} 5878$ U.S.N.M./ LECTOTYPE/ Narope marmorata Schaus, 1902, Lectotype, M. M. Casagrande det. 2002/. O outro exemplar mencionado na descrição original como possuindo "the upper surface of a more uniform brown, merely the apex and outer margins being slightly darker" e com as etiquetas: Narope marmorata type Schaus/Bolívia/ Collection W. Schaus/ Type N 5878 U.S.N.M./ é um exemplar de Narope syllabus syllabus Staudinger, 1887.

Diagnose. Face dorsal das asas anterior e posterior castanho claro. Ápice e margem costal ta asa anterior escurecidos, interior da célula discal, sobre base de $\mathrm{R}_{4}-\mathrm{R}_{5}$, espaço $\mathrm{M}_{1}-\mathrm{M}_{2}$ e sobre $\mathrm{M}_{3}, \mathrm{CuA}_{1}$ e $\mathrm{CuA}_{2}$, escamas ferrugíneas.

Descrição. Macho (Figs 87 e 90). Asa anterior: comprimento da margem costal - 30 a $34 \mathrm{~mm}$; margem externa - 21 a $23 \mathrm{~mm}$; largura da asa -21 a $22 \mathrm{~mm}$. Asa posterior: comprimento da margem costal -20 a $21 \mathrm{~mm}$; margem externa - 23 a $25 \mathrm{~mm}$; maior comprimento da asa - 27 a $28 \mathrm{~mm}$.

Cabeça e apêndices, tórax e abdome castanho.

Face dorsal das asas anterior e posterior castanho. Ápice da asa anterior destacado pelas escamas escuras, quase pretas; na margem costal, interior da célula discal, sobre a base de $\mathrm{R}_{4}$ e $\mathrm{R}_{5}$, no espaço $\mathrm{M}_{1}-\mathrm{M}_{2}$ e sobre $\mathrm{M}_{3}, \mathrm{CuA} \mathrm{A}_{1}$ e CuA2, escamas ferrugíneas, restante da asa castanho. Asa posterior com a margem externa crenulada, maior projeção acompanhada pela $\mathrm{CuA}_{1}$; androcônia oval, de tamanho médio, creme, pouco além da bifurcação Rs-M $\mathrm{M}_{1}$, sobre Rs. 
$\mathrm{Na}$ face ventral da asa anterior, com cor predominante bege e com vários conjuntos de escamas castanho. Discreta linha submarginal sinuosa e escura. Do ápice até o meio de $2 \mathrm{~A}$, faixa diagonal, com aproximadamente $1 \mathrm{~mm}$ de largura e de escamas claras, divide a asa em duas áreas; a distal, mais escura, diminuindo de intensidade conforme se aproxima da margem externa e a proximal mais clara. Nesta, duas outras faixas, uma basal formada por várias elipses, dentro da célula, de contorno escuro e parte interna mais clara e outra, pós-basal, desde a margem costal, passando sobre as discocelulares até $\mathrm{M}_{3}$ e pelo lado externo da célula até o meio de $2 \mathrm{~A}$. Sobre a metade proximal de $2 \mathrm{~A}$, androcônia de forma arredondada, pouco menor que aquela da face dorsal da asa posterior.

$\mathrm{Na}$ face ventral da asa posterior, as mesmas tonalidades da asa anterior com menos espaços de escamas bege. Linha submarginal escura e marcada de forma sinuosa, como a margem da asa. Anterior a ela, faixa com dois a três milímetros de largura de escamas escuras, antecedidas por escamas brancas com reflexos violáceos. Faixa basal castanho escuro, desde a margem costal até o meio de $2 \mathrm{~A}$. Da faixa basal, ocupando a metade distal da célula discal e se projetando até $3 \mathrm{~A}$, faixa pós-basal castanho escuro.

Genitália (Fig. 87A-E). Unco reto com projeção lateral serrilhada, não em ponta, e dorsalmente com inúmeros espinhos, as partes laterais destas projeções convergem dorsalmente, formando uma crista pouco projetada sobre o dorso do unco; subunco alongado, em forma de "foice", extremidade proximal estreita alargando-se progressivamente até a metade do comprimento e estreitando novamente para terminar de forma arredondada; toda a borda ventral serrilhada, incluindo a extremidade distal; espinhos revestem a metade distal externa. Valva projetada para além do unco; extremidade distal com duas pontas, sendo que a anterior se projeta sobre a distal. Juxta, em vista ventral, em forma de $\mathrm{V}$ expandido, com a margem distal serrilhada.

Fêmea. Desconhecida.

Discussão. A coloração das asas anterior e posterior, tanto dorsal como ventralmente e o contorno crenulado com projeção acentuada na $\mathrm{CuA}_{1}$ na margem externa da asa posterior caracterizam a espécie. A comparação de exemplares de $N$. marmorata e $N$. anartes, tanto pelo aspecto cromático da asa como pelas genitálias masculinas, identificam cada uma delas como espécies distintas, além de simpátricas.

Distribuição espacial (Fig. 99). PerU, Junín: Rio Perené; Satipo. BolíviA, Santa Cruz: Buenavista (Ichilo); Cochabamba: Yungas del Palmar.

Distribuição temporal. Pelo material estudado pode-se concluir que a espécie voa nos meses de março, agosto a novembro.

Etologia. Desconhecida

Planta hospedeira e imaturos. Desconhecidos, mas acredita-se que devam alimentar-se de Poaceae.

Material estudado. Peru, Junín: Rio Perené, 200-500 m, 2 machos, IXXI.1987, Tello leg. (OM); Satipo, 700 m, 1 macho, 20. III.1981 (OM); BolíVIA, 2 machos (MNRJ), 1 macho (UFPC); Santa Cruz: Buenavista, Ichilo, 400 m, 1 macho (UFPC); Cochabamba: Yungas del Palmar, 1000 m, 1 macho, VIII.1948 (UFPC). 


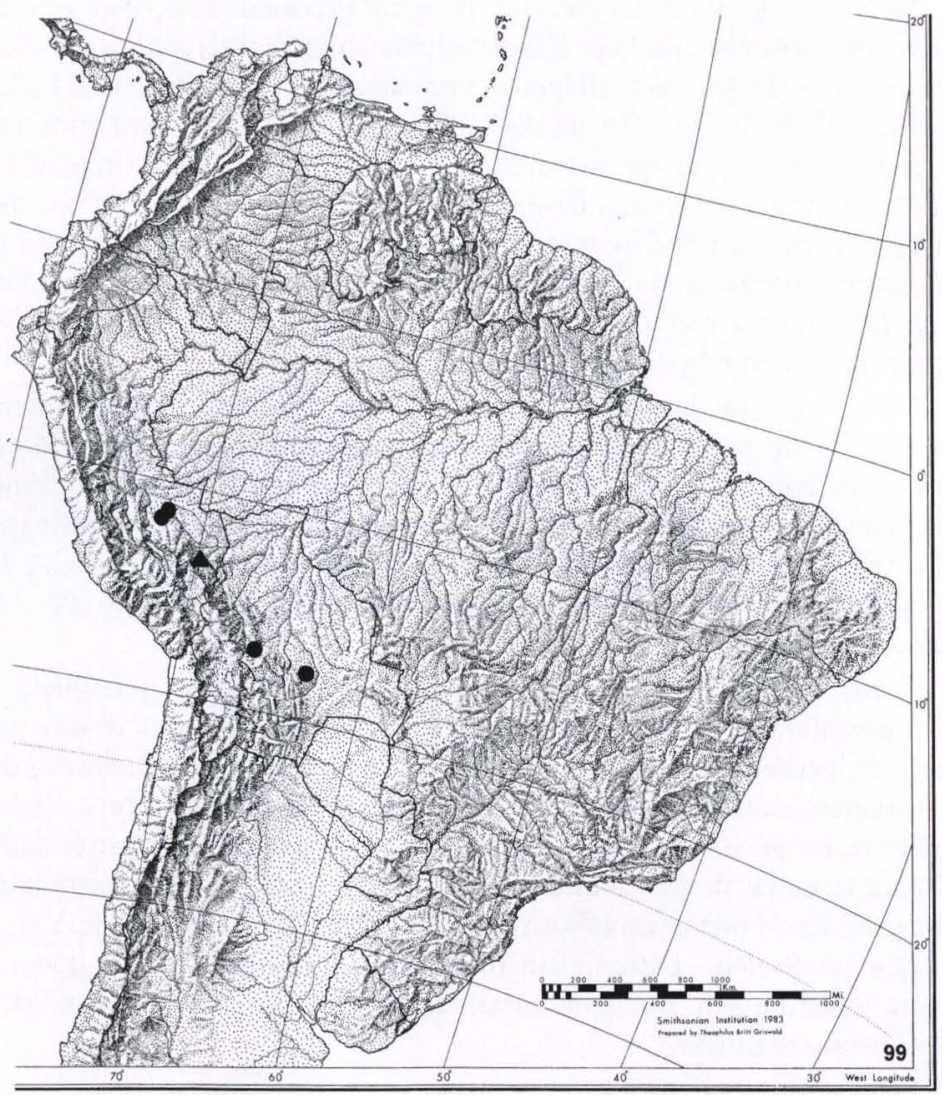

Fig. 99. Distribuição espacial. (•) Narope marmorata, (A) Narope albopunctum.

\section{Narope albopunctum Stichel, 1904}

Figs 95 e 99

Narope albopunctum Stichel, 1904. Ins.- Börse 21: 6; 1 fêmea [recte macho, holótipo], Marcapata, [Cuzco], Peru, coleção Staudinger.- Stichel, 1904. Gen. Ins. 20, p. 16; cat., dg.- Stichel, 1909. Tierreich 25, p. 42, 50, fig. 13 (macho d, v); cat., dg.-Fruhstorfer, 1912, in Seitz. Gross-Schmett. Erde, 5, p. 330; sist., dg.-Stichel, 1932. Lep. Cat. 51, p. 17; cat., dg.-Lamas, 1969. Biota, Lima, 7: 290; dg.- Lamas, 1985. Rev. peruana Ent. 27: 70; dg.- D’Abrera, 1987. Butt. Neotrop. Reg. 3, p. 392, fig. (macho d; macho v = testacea); sist., dg.- Casagrande, 1996. Revta bras. Zool. 12: 684 ; sist.

Histórico. Na descrição original STICHEL (1904) cita a espécie fundamentada em um exemplar fêmea da Coll. Staudinger. LAMAS $(1969,1985)$ sugere que a espécie possa ocorrer em Tambopata, Madre de Dios, Peru, porém nunca foi vista ou coletada nesta localidade. Na referência de D'ABRERA (1987), a figura da face vental de $N$. albopunctum é de $N$. testacea. 
Material tipo. HOLÓTIPO macho (nec fêmea, como na descrição original) no "Zoologisches Museum der Humboldt Universität" Berlim, Alemanha, com as seguintes etiquetas: /Narope albopunctum Stichel/ Zool. Mus. Berlin/ Marcapata Peru/ HOLOTYPE/ Narope albopunctum Stichel, 1904, Holotype, M.M. Casagrande det. 2002/.

Diagnose. Face dorsal das asas anterior e posterior castanho escuro. Na anterior ponto branco em $\mathrm{R}_{5}-\mathrm{M}_{1}$ e na posterior, tufo de pêlos odoríferos dentro da célula discal. Asa posterior com faixa diagonal escura na face ventral de ambas as asas.

Descrição. Macho (Fig 95). Cabeça e apêndices, tórax e abdome castanho.

Face dorsal das asas anterior e posterior castanho escuro. Na asa anterior, ponto subapical de escamas brancas em $\mathrm{R}_{5}-\mathrm{M}_{1}$. Na asa posterior linha marginal escura; sobre a base de $\mathrm{CuA}_{1}$, dentro da célula discal, um pincel de pêlos.

Face ventral das asas anterior e posterior mais clara, com faixa marginal mais escura de aproximadamente $1 \mathrm{~mm}$ de espessura. $\mathrm{Na}$ asa anterior faixa diagonal de escamas escuras com início na margem costal, pouco antes do ápice, até o meio de 2A. O ponto de escamas brancas ocupa igual posição na face ventral, outro menor, de escamas escuras, pouco mais abaixo. Do ápice até o angulo anal, área de pequenos pontos brancos.

Face ventral da asa posterior, faixa diagonal de escamas escuras, da metade da margem costal até o meio da margem interna. Na metade proximal, junto à faixa de escamas escuras, outra de escamas claras que dispersam em direção à base. $\mathrm{Na}$ metade distal, linha de pontos com escamas escuras, distribuídos desde a margem costal, de forma convexa, até a linha diagonal na margem interna.

Discussão. São conhecidos apenas dois exemplares, ambos machos, inclusive o holótipo equivocadamente identificado por STICHEL (1904) como fêmea. As asas são completamente castanho escuro com ponto de escamas brancas em R5-M que diferenciam as espécies de todas as demais.

Distribuição espacial (Fig. 99). PERU, Cuzco: Marcapata.

Distribuição temporal. Desconhecida.

Etologia. Desconhecida.

Planta hospedeira e imaturos. Desconhecidos.

Material estudado. PERU, Cuzco: Marcapata (holótipo, ZMHB) e um macho sem procedência (BMNH).

\section{Aponarope Casagrande, 1982}

Figs 100-106

Espécie tipo: Aponarope sutor (Stichel, 1916).

Aponarope Casagrande, 1982. Revta bras. Ent. 26 (3/4): 356; espécie tipo: Narope sutor.-Casagrande, 1996. Revta bras. Zool. 12: 687; sist.

Caracterização morfológica (Figs 100-106). Asa anterior com margem externa côncava e de ápice recuado. Com 12 veias que atingem as margens costal e externa. $\mathrm{R}_{3}$ termina no ápice da asa. $\mathrm{Na}$ asa posterior com margem externa reta $\mathrm{e}$ ângulo anal projetado em $2 \mathrm{~A}$. 
$\mathrm{Na}$ face dorsal da asa posterior, dentro da célula umeral e sobre a base da bifurcação $\mathrm{Sc}+\mathrm{R}_{1}$-Rs até pouco além da base da bifurcação $\mathrm{Rs}$ com $\mathrm{M}_{1}$, área de aspecto brilhoso e sem escamas. No centro dessa área, pouco além da bifurcação Rs- $M_{1}$, sobre Rs, escamas diferenciadas formam uma androcônia de tamanho grande, oval e creme. Ausência de estrutura odorífera na célula discal da asa posterior.

$\mathrm{Na}$ face ventral da asa anterior, sobre a metade proximal de $2 \mathrm{~A}$, androcônia com escamas creme, com aproximadamente o mesmo tamanho que aquela da face dorsal da asa posterior. Sobre essas escamas um pincel de pêlos, distribuídos de forma linear em uma dobra formada pela margem interna da asa. A extensão da faixa de pêlos corresponde ao tamanho da mancha.

Nos machos, fêmur das pernas meso e metatorácica com espinhos.

Nas fêmeas, o fêmur da perna protorácica é maior que a tíbia, chegando próximo ao ápice do tarso.

Genitália masculina com valva alargada e truncada na porção distal e de bordo levemente crenulado. Juxta presente. Edeago liso, com vesica se projetando da face ventral. Genitália feminina com placa pós-vaginal fortemente esclerotinizada, com as extremidades laterais retorcidas e dirigidas dorsalmente.

Espécie incluída. Aponarope sutor (Stichel, 1916).

Etimologia. O nome genérico significa "retirado de Narope".

\section{Aponarope sutor (Stichel, 1916)}

Figs 100-106

Narope sutor Stichel, 1916. Neue Beitr. syst. Insektenk. 1: 7; [holó]tipo, macho, $\mathrm{n}^{\circ} 475$, Mato Grosso, Brasil; coleção Stichel.- Stichel, 1932. Lep. Cat. 51, p. 17; syn.: pluto; cat.

Narope panniculus panniculus; Stichel, 1916. Neue Beitr. syst. Insektenk. 1: 8; sist., fêmea.

Narope pluto Tessmann, 1928. Mitt. Zool. Mus. Berlin 24: 124, pl. 5, fig. 23 (macho v); 3 machos,

Montealegre, médio Pachitea, [Huánuco], Peru, 270 m, Tessmann \& Pape leg.; Zoologisches

Museum Berlin.

Aponarope sutor; Casagrande, 1982. Revta bras. Ent. 26: 356; sist.-Lamas, 1985. Rev. peruana Ent.

27: 70; dg. -Casagrande, 1996. Revta bras. Zool. 12: 686, figs 32, 35 (gen. masc.); sist.

Histórico. A espécie foi descrita duas vezes, sendo o segundo nome, Narope pluto, corretamente sinonimizado por STICHEL (1932). A citação de Narope panniculus panniculus de STICHEL (1916) refere-se a esta espécie, pois o exemplar foi estudado no Zoologisches Museum der Humboldt Universität, Berlim, Alemanha. CASAGRANDE (1982) cria o gênero Aponarope e transfere Narope sutor, para esse gênero, considerando as diferenças morfológicas apresentadas, quando comparadas às outras espécies de Narope.

Material tipo. O único exemplar utilizado por STICHEL (1904) para a descrição, ou seja, o HOLÓTIPO de N. sutor está no "The Natural History Museum", Londres, Inglaterra, com as seguintes etiquetas: /TYPE/ Brasilien, Mato Grosso, e c. H. Stichel/ TYPUS/HOLOTYPE/ Narope sutor Stichel, 1904, Holotype, M. M. Casagrande det. 2002/.

TESSMANN (1928) baseou a descrição, de $N$. pluto em três exemplares [SÍNTIPOS] dos quais um está no "Zoologisches Museum der Humboldt Univer- 
sität", Berlim, e é aqui designado como LECTÓTIPO, com o objetivo de garantir a adequada identificação da espécie, com as seguintes etiquetas: /TYPE/ O.Peru, Rio Pachitea. G. Tessmann S./ N. pluto m. det. G. Tessmann/LECTOTYPE/ Narope pluto Tessmann, 1928, Lectotype, M. M. Casagrande det. 2000/. Um dos outros síntipos, no Museu Nacional do Rio de Janeiro, Brasil, é aqui designado como PARALECTÓTIPO.

Diagnose. Asas anterior e posterior castanho escuro com nuances ferrugíneo. Androcônia de escamas claras nas asas posteriores; Sc separada de $\mathrm{R}_{1}$. Genitália masculina com valva alargada e truncada na porção distal e, de bordo levemente crenulado.

Descrição. Macho (Figs 100, 102-104). Cabeça, tórax e abdome, castanho escuro. Antenas ferrugíneas.

Asa anterior: comprimento da margem costal - 31 a $34 \mathrm{~mm}$; margem externa -25 a $27 \mathrm{~mm}$; largura da asa -24 a $26 \mathrm{~mm}$. Asa posterior: comprimento da margem costal - 23 a $25 \mathrm{~mm}$; margem externa - 25 a $26 \mathrm{~mm}$; maior comprimento da asa 25 a $27 \mathrm{~mm}$.

Asas anterior e posterior com a face dorsal em castanho escuro. Na anterior, ápice e margem externa enegrecida, nas porções mediana e basal castanho escuro com nuances ferrugíneo. $\mathrm{Na}$ asa posterior, ferrugíneo presente apenas em uma pequena área entre a célula discal e o ápice, este como na asa anterior enegrecido; sobre a célula umeral, base da bifurcação $S c+R_{1}-R s$ até a base da bifurcação Rs- $M_{1}$, área diferenciada, sem escamas e de aspecto brilhoso; no centro desta área, logo após a bifurcação de Rs-M1, sobre Rs, escamas odoríferas formam uma androcônia, oval, creme e de aproximadamente $4 \mathrm{~mm}$ no maior eixo.

Face ventral da asa anterior, castanho com nuances e faixas castanho escuro distribuídas da seguinte forma; faixa marginal com $1 \mathrm{~mm}$ de largura, acompanha toda a margem externa; faixa com $2 \mathrm{~mm}$ de largura, de escamas castanho claro, desde o ápice até a parte mediana da margem interna; faixa basal, no meio da célula discal, castanho escuro e a pós-basal sobre as discocelulares da mesma cor que a basal.

Sobre a metade proximal de $2 \mathrm{~A}$, mancha odorífera com escamas creme pouco menor que aquela da face dorsal da asa posterior. Sobre a androcônia pincel de pêlos ferrugíneos, distribuído de forma linear sobre uma dobra formada pela margem interna da asa. A extensão da faixa de pêlos corresponde ao tamanho da mancha.

$\mathrm{Na}$ face ventral da asa posterior, faixa levemente convexa com $2 \mathrm{~mm}$ de largura, castanho claro, desde a metade da margem costal e de forma diagonal até meio de $2 \mathrm{~A}$. No início desta faixa um pequeno ponto de escamas escuras externamente e claras na parte central é seguido por um conjunto de outros pontos mais claros, distribuídos nos espaços entre as veias seguintes e em semicírculo, acompanhando o contorno da asa, estes pontos são diferentes do primeiro pois são de escamas claras. Linha marginal similar à da asa anterior. Entre essa e a linha de pontos, uma faixa de reflexo prata; este reflexo também pode ser observado, na área escura, logo acima da faixa clara. 

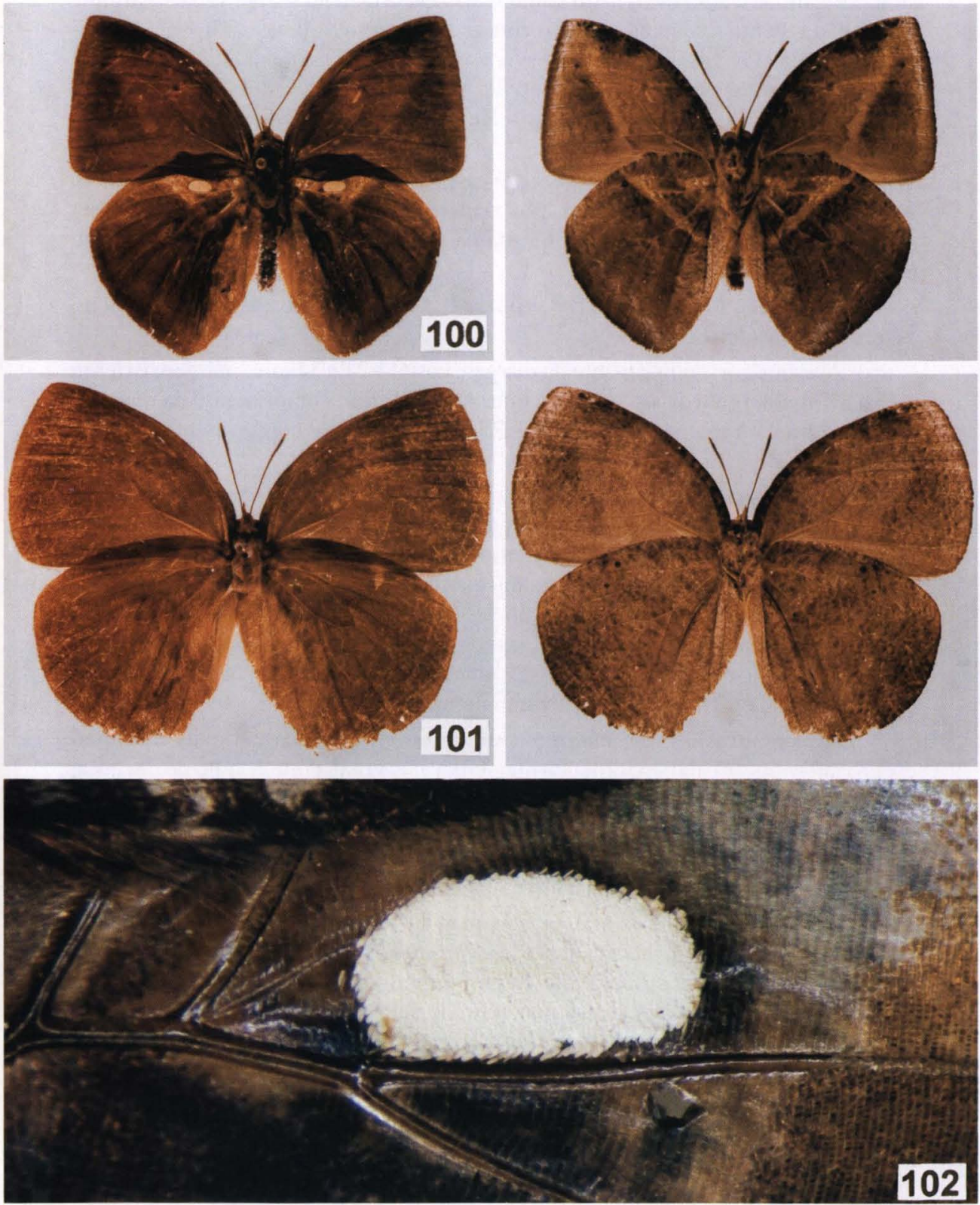

Figs 100-102. Aponarope sutor. (100) Macho, vistas dorsal e ventral; (101) fêmea: vistas dorsal e ventral; (102) androcônia, asa posterior do macho, face dorsal.

Revta bras. Zool. 19 (2): $467-569,2002$ 


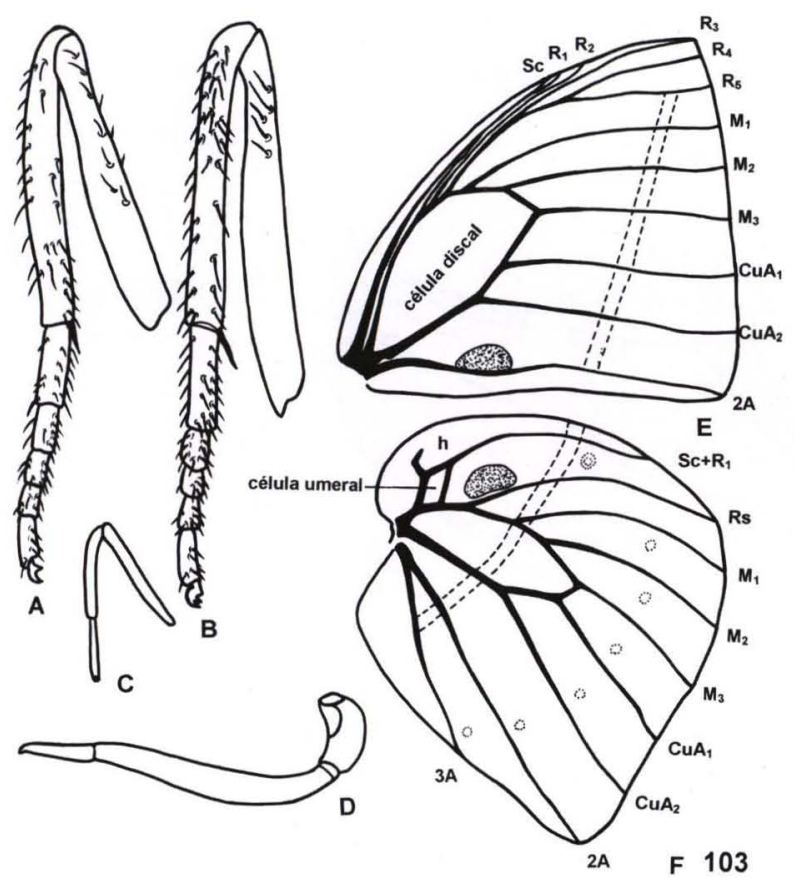

Fig. 103. Aponarope sutor, macho: (A) perna metatorácica, $(B)$ perna mesotorácica, $(C)$ perna protorácica, (D) palpo labial, (E) asa anterior, (F) asa posterior.

Genitália (Fig. 104A-E). Unco curvo, com a margem distal inferior serreada. Subunco liso e alongado, duplamente retorcido e com três projeções apicais que ultrapassam o unco dorsalmente. Base da valva tão larga quanto a altura do tegume; porção distal alargada e truncada e, de bordo levemente crenulado; externamente, borda superior fortemente esclerotinizada e inferior a este, estreita faixa membranosa. Projeção anterior do saco curta, tão larga quanto longa. Juxta, em vista ventral, em forma de V, com a porção distal completamente deprimida. Edeago delicado, quando comparado ao restante da genitália.

Fêmea (Figs 101 e 105). Cabeça e apêndices, tórax e abdome castanho. Asa anterior: comprimento da margem costal $-34 \mathrm{~mm}$; margem externa - $25 \mathrm{~mm}$; largura da asa $-26 \mathrm{~mm}$. Asa posterior: comprimento da margem costal $-27 \mathrm{~mm}$; margem externa $-27 \mathrm{~mm}$; maior comprimento da asa $-28 \mathrm{~mm}$.

Asas anterior e posterior com a face dorsal uniformemente castanho, com apenas linha marginal mais clara de aproximadamente $1 \mathrm{~mm}$ de largura, na margem de ambas as asas, pouco mais clara que o restante. Face ventral de ambas as asas pouco mais clara que a dorsal e com inúmeros pontos de escamas escuras. $\mathrm{Na}$ asa posterior, como nos machos, com semicírculo de pontos, distribuídos entre as veias longitudinais, acompanham a forma convexa da margem externa. 


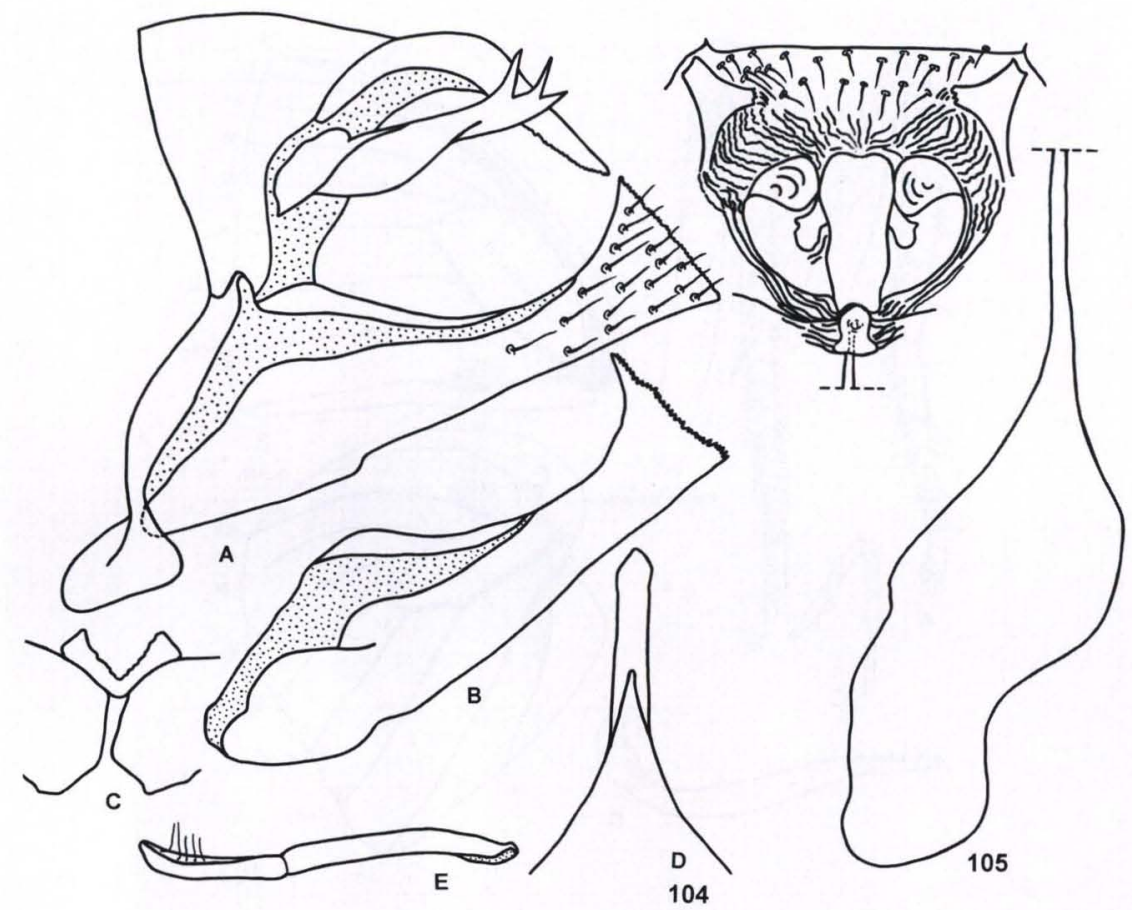

Figs 104-105. Aponarope sutor. (104) Genitália masculina: (A) vista lateral, (B) valva, vista lateral interna, (C) juxta, vista ventral, (D) tegume/unco, vista dorsal, (E) edeago, vista lateral; (105) genitália feminina, vista ventral.

Genitália (Fig. 105). Lamela pós-vaginal retangular e fortemente esclerotinizada, retorcida e com os braços laterais dirigidos dorsalmente. Lamela ante-vaginal pequena. Duto da bolsa pouco menor que a bolsa; corpo da bolsa alongado.

Discussão. Embora de formato alar similar à algumas espécies de Narope, como N. nesope e N. cyllabarus, é distinta da primeira pela androcônia da face dorsal das asas posteriores acentuadamente maior e ausência de mancha preta na face dorsal da asa anterior, e da segunda pela ausência da cor laranja na face dorsal das asas; distingue-se das espécies de Narope de maneira geral, pela presença de espinhos nos fêmures meso e metatorácicos e pelo padrão das genitálias masculina e feminina.

Distribuição espacial (Fig. 106). Peru, Madre de Dios: Puerto Maldonado (Tambopata) 300 m; Huánuco: Montealegre (Rio Pachitea) 270 m. BRAsIL, Acre: Alto Juruá; Amazonas: Huitanaã; Pará: Itaituba; Rondônia: Vilhena; Mato Grosso: Diamantino.

Distribuição temporal. Com base no material do Mato Grosso, pode-se sugerir que se não voa durante todo o ano, possui duas gerações anuais já que tem-se exemplares de janeiro e setembro-outubro. 


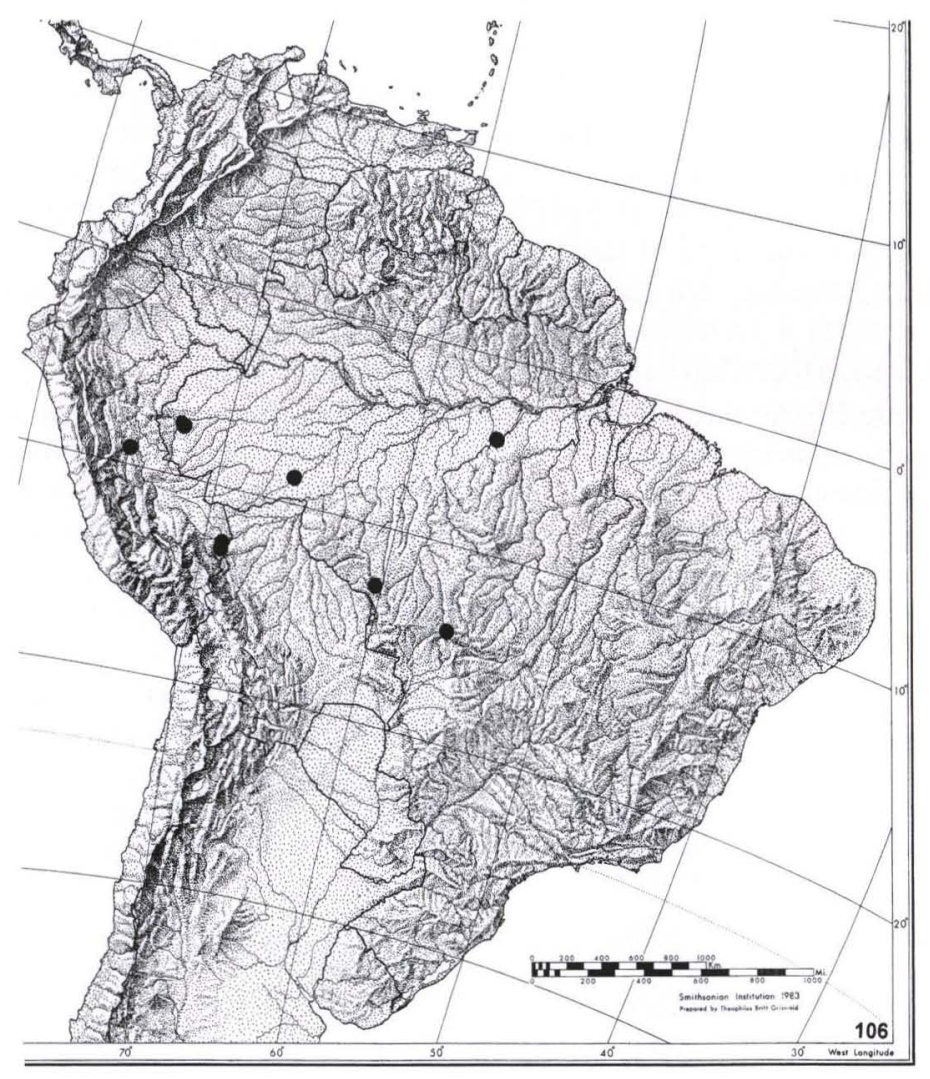

Fig. 106. Aponarope sutor, distribuição espacial.

Etologia. São crepusculares e de vôo rápido. Machos podem ser coletados em armadilhas suspensas com frutas em decomposição e a única fêmea que dispomos foi coletada (O.H.H. Mielke) sobre excremento humano, dentro da mata logo pela manhã.

Planta hospedeira e imaturos. Desconhecidos, mas acredita-se que devam alimentar-se de Poaceae.

Material estudado. Peru, Madre de Dios: Puerto Maldonado, Tambopata Reserve, 300 m, 1 macho, 27.X.1991, Mielke leg. (UFPC); 2 machos, VII.1988, Büche leg. (OM); Huánuco: Montealegre, Rio Pachitea, entre Rio Pichis-Palcazu e a foz, 2 machos (LECTÓTIPO e PARALECTÓTIPO machos de N. pluto), Tessmann \& Pape leg. (ZMHB, MNRJ). BRASIL, Amazonas: Huitanaã, Rio Purus, 1 macho, III.1922, S.M. Klages leg. (CMP); Pará: Itaituba, [Rio] Tapajós, 1 fêmea, 1890, Michael [leg.] (ZMHB); Acre: Alto Juruá, 2 machos (MNRJ); Rondônia: Vilhena, 1 macho, 10.X. 1986, Elias leg. (UFPC); Mato Grosso: Diamantino, Faz. São João, Alto Rio Arinos, 1 macho e 1 fêmea, 22.I.1978 e 13.IX.1978, Furtado \& Mielke leg. (UFPC). 


\section{CONCLUSÕES}

Imaturos de Narope cyllene $\mathrm{C}$. Felder \& R. Felder, 1859 utilizam como planta hospedeira Chusquea leptophylla Nees (Poaceae) e o ciclo completo, desde oviposição até o aparecimento dos primeiros adultos dura aproximadamente 75 dias. As larvas atingem o comprimento máximo de $7,3 \mathrm{~cm}$. A interpretação da quetotaxia da cabeça da larva de primeiro estádio é dificultado pelo grande número de cerdas ramificadas e a do corpo, ao contrário, é facilitada pelo reduzido número de cerdas. Estudos de imaturos em Naropini, exceto pelo trabalho de CASAGRANDE (1992), estão restritos à identificação da planta hospedeira, o que impede um melhor entendimento das relações entre as espécies e com o meio.

Em função dos hábitos crepusculares apresentados, os adultos, são muito pouco coletados e portanto a sua representatividade em coleções é restrita. Também são insuficientes os dados relacionados com a distribuição espacial, já que supostamente algumas espécies podem apresentar uma ampla distribuição, estão na prática (material disponível) restritas à áreas isoladas, ou seja, de distribuição disjunta, apontando para uma necessidade de coletas, no mínimo entre estas áreas com florestas, seu habitat natural.

Com base nos estudos feitos, os gêneros que compõem a tribo Naropini, Aponarope Casagrande, 1982 e Narope Doubleday, [1849], são monofiléticos. Aprofundamentos em estudos morfológicos com criteriosas análises das variações estruturais são necessárias, assim como, estudos complementares de bioquímica e microscopia eletrônica, para o melhor embasamento de caracteres e análise filogenética.

A partir desse estudo, a tribo Naropini fica assim constituída:

Brassolinae (Boisduval, 1836) Bates, 1861.

Naropini (Stichel, 1925) Casagrande, 1996

Aponarope Casagrande, 1982

Aponarope sutor (Stichel, 1916)

Narope pluto Tessmann, 1928, syn. n.

Narope Doubleday, [1849]

Narope albopunctum Stichel, 1904

Narope anartes Hewitson, 1874

Narope sarastro Staudinger, [1886], syn. n.

Narope sarastro disyllus Fruhstorfer, 1912, syn. n.

Narope cauca Casagrande, sp. $\mathbf{n}$.

Narope cyllabarus Westwood, 1851

Narope cyllarus Westwood, 1851

Narope cyllastros Doubleday [1849]

Narope cyllene C. Felder \& R. Felder, 1859

Narope denticulatus Talbot, 1928, stat. n.

Narope guilhermei Casagrande, 1989

Narope marmorata Schaus, 1902, nom. rev.

Revta bras. Zool. 19 (2): 467 - 569, 2002 
Narope nesope Hewitson, 1869

Narope pusilla Röber, 1929, syn. n.

Narope obidos Casagrande, sp. $\mathbf{n}$.

Narope panniculus Stichel, 1904

Narope panniculus piccatus Stichel, 1916, syn. n.

Narope syllabus Staudinger, 1887

Narope syllabus syllabus Staudinger, 1887

Narope syllabus stygius Staudinger, 1887, ssp. n., comb. n.

Narope testacea Godman \& Salvin, 1878, stat. rev.

Narope ybyra Casagrande, sp. $\mathbf{n}$.

AGRADECIMENTOS. À todas as pessoas e instituições, mencionadas no item "Material e Métodos". Ao Prof. Dr. Olaf H.H. Mielke, pelo auxílio nas fotografias, pelo incentivo para preparar esse artigo, revisões e principalmente pelo contínuo aprendizado através das discussões que o convivio tem possibilitado. Ao Dr. Gerardo Lamas (Museo de Historia Natural, Lima, Peru), pela revisão do manuscrito, sugestões e atenção, ao Dr. Robert Robbins (National Museum of Natural History, Smithsonian Institution, Washington, DC, EUA) pela permissão para o uso do mapa das distribuições, ao Dr. Armando Cervi (Departamento de Botânica, da Universidade Federal do Paraná) pela identificação da planta hospedeira de Narope cyllene. Aos amigos Dra Danúncia Urban pela revisão e sugestões além da alegria de todos os dias e ao Dr. Albino Morimasa Sakakibara pela sempre disponibilidade.

\section{REFERÊNCIAS BIBLIOGRÁFICAS}

ACKERY, P.R. 1988. Hostplants and classification: a review of nymphalid butterflies. Biol. Jour. Linnean Soc., London, 33: 95-203.

BAR, M.C. 1878. Note critique sur les différents systèmes de classification des Lépidoptères Rhopalocères établis depuis l'époque de Latreille et essai d'une nouvelle classification jusqu'aux genres exclusivement. Ann. Soc. ent. Fr., Paris, 8 (5): 5-30.

BATES, H.W. 1864. Contributions to an insect fauna of the Amazon Valley. Lepidoptera-Nymphalidae. Jour. Ent., London, 2: 175-213.

BAtes, M. 1932. Notes on the metamorphosis of the Brassolidae (Lepidoptera). Bull. Brooklyn Ent. Soc., Lancaster, 27: 155-163.

Bergallo, H.G.; C.F. Duarte da Rocha; M.A. dos Santos Alves \& M.van Sluys. 2000. A fauna ameaçada de extinção do Estado do Rio de Janeiro. Rio de Janeiro, Ed. Universidade do Estado do Rio de Janeiro, $62+4 \mathrm{p}$.

BönNinghaUSEn, V. von. 1896. Beitrag zur Kenntnis der Lepidopteren-Fauna von Rio de Janeiro. Verh. Ver. naturw, Unterh., Hamburg, 9: 19-41.

BoISDUVAL, J.B.A. 1836. Histoire naturelle des Insectes. Spécies géneral des Lepidoptères 1. Paris, Libr. Encyclopédique de Roret, 690p.

— 1870. Considérations sur des Lépidoptères envoyès du Guatemala à M. de l'Orza. Rennes, Oberthür \& Fils, 100p.

BROWN JR., K.S., 1992. Borboletas da Serra do Japi: diversidade, hábitos, recursos alimentares e variação temporal, p. 142- 187, $105+4$ figs. In: L.P.C. Morellato (Ed.). História Natural da Serra do Japi. Ecologia e preservação de uma área florestal no Sudeste do Brasil. São Paulo, Editora UNICAMP/FAPESP, 321p.

BURMEISTER, H.C.C. 1855. Kritische Bemerkungen ueber M.S. Merian Metamorphoses Insectorum Surinamensis. Sitzber. Abhandl. Naturf. Gesell. Halle 2 (1854), p. 58-65. 
CASAgrande, M.M. 1979. Sobre Caligo beltrao (Illiger). I. Taxonomia, biologia, morfologia das fases imaturas e distribuições espacial e temporal (Lepidoptera, Satyridae, Brassolinae). Rev. Bras. Biol., Rio de Janeiro, 39 (1): 173-193.

. 1982. Quatro gêneros novos de Brassolinae (Lepidoptera-Nymphalidae). Revta bras. Ent., São Paulo, 26 (3/4): 355-356.

- 1989. Espécie nova de Narope do sul do Brasil (Lepidoptera, Nymphalidae, Brassolinae). Revta bras. Zool. 6 (1): 125-129.

- 1992. Narope cyllene Felder \& Felder, sp. rev. Redescrição e fases imaturas. (Lepidoptera, Nymphalidae, Brassolinae). Revta bras. Zool. 7(1-2): 129-145.

- 1996. Notas sistemáticas sobre Brassolinae. I. Tribos. (Lepidoptera, Nymphalidae). Revta bras. Zool. 12 (3): 671-699.

CAsagrande, M.M. \& O.H.H. MielKe. 1993. Borboletas (Lepidoptera) ameaçadas de extinção no Paraná. Revta bras. Zool. 9 (1/2): 75-92.

1995. Fauna do Paraná ameaçada de extinção - Lepidoptera, p. 145-57. In: M.G.P.

Tossulino; T.C.C. Margarido; F.C. StRaube; J.C.M. Leite; S.A.A. Morato; R.S. Bérnils; M.M. CASAGRANDE \& O.H.H. MielKe (Eds) Lista vermelha de animais em extinção no estado do Paraná. Curitiba, Secretaria do Estado do Paraná e Deutsche Geselschaft für Technische Zusammenarbeit, 178p.

- 2000. Larva de quinto estádio e pupa de Caligo martia (Godart). (Lepidoptera, Nymphalidae, Brassolinae), Revta bras. Zool. 17 (1): 75-79.

2000. Larva de quinto estádio e pupa de Dasyophthalma rusina rusina (Godart).

(Lepidoptera, Nymphalidae, Brassolinae). Revta bras. Zool. 17 (2):401-404.

LuCAS, H. 1851. In: J.C. ChENu. 1851-52. Encyclopédie d' Histoire Naturelle, Papill., p.172-173.

CRUeger, C. 1879. Über exotische Lepidopteren. Verh. Ver. naturw. Unterh., Hamburg, 4: 192-198.

D' Abrera, D.J. 1987. Butterflies of the Neotropical Region. Part III. Brassolidae, Acraeidae \& Nymphalidae (partim). Victoria, Black Rock, Hill House, 525p.

DEVRIES, P.J. 1986. Hostplant records and Natural History notes on Costa Rican Butterflies (Papilionidae, Pieridae \& Nymphalidae). Jour. Res. Lep. 24 (4): 290-333.

- 1987. The Butterflies of Costa Rica and their Natural History. Papilionidae, Pieridae, Nymphalidae. Princeton, Univ. Press, 327p.

DeVRIES, P.J.; I.J. KItching \& R.I. VANE-WRIGHT. 1985. The systematic position of Antirrhea e Caerois, with coments on the classification of the Nymphalidae (Lepidoptera). Syst. Ent. 10: 11-32.

DiAs, M.M. 1979. Morfologia e biologia de Eryphanis polyxena polyxena (Meerburgh, 1775) (Lepidoptera, Satyridae, Brassolinae). Revta bras. Ent., São Paulo, 23 (4): 267-274.

DOUBLEDAY, E. 1846-[1852]. The genera of diurnal Lepidoptera, comparing their generic characters, a notice of their habitats and transformations and a catalogue of the species of each genus; illustrated with 86 plates by W.C. Hewitson. London, 536p.

EHRLICH, P.R. 1958. The comparative morphology, Phylogeny and higher classification of butterflies (Lepidoptera: Papilionoidea). Univ. Kansas Sci. Bull. 39 (8): 305-369.

EhrLich, P.R. \& P.H. Raven. 1965. Butterflies and plants: a study in coevolution. Evolution 18: 586-608.

EMMEL, T.C. 1991. A note on the life history of Dynastor napoleon in Southern Brazil (Lepidoptera: Nymphalidae: Brassolinae). Trop. Lep. 2 (2): 151-153.

FASSL, A.H. 1918. Die vertikale Verbreitung der Lepidopteren in der Columbischen Ost-Cordillere. Ent. Rdsch., Stuttgart, 35 (8): 30-31.

Felder, C. \& R. Felder. 1859-1860. Lepidopterologisches Fragmente. Wien. Ent. Monatschr. 3 (1859): p. 178-186, 2 Taf., p. 263-273, 1 Taf., p. 321-328, 390-405, 5 Taf.; 4 (1860): p. 97-112, 2 Taf., p. 225-251, 2 Taf.

- 1862. Specimen faunae lepidopterologicae riparum fluminis Negro superioris in Brasilia septentrionali. Wien. Ent. Monatschr., Wien, 6 (3): 65-80, 109-126, 175-192, 229-235.

1867. Reise der österreichischen Fregatte Novara um die Erde in den Jahren 1857, 
1858, 1859 unter den Befehlen des Commodore B. von Wüllerstorf-Urbair. Zoologischer Theil. Zweiter Band. Zweite Abtheilung: Lepidoptera. Wien, Carl Gerold's Sohn. (1): [4] + 1-136 pls 1-21 ([12 January 1865]), (2): [2] + 137-378, pls 22-47 ([after October]) 1865), (3): [2] + 379-536, pls 48 - 74 ([25 April] 1867.

FruHSTORFER, H. 1912. Brassolidae, p. 285-332, pls 61-67. In: A. SEITZ. Gross-Schmett. Erde, 5, Alfred Kernnen, Stuttgart., 1139.

GERHARD, B. 1883. Über die geograpische Verbreitung der Macro-Lepidopteren auf der Erde. Berl. ent. Ztschr., Berlin, 27: 173-185.

Glaser, L. 1887. Exotische Schmetterlingsgattungen. Cat. Etymol. Coleop. et Lepidopt. Berlin, $396 p$.

Godman, F.D. \& O. Salvin. 1879-1901. Biologia Centrali-Americana. Lepidoptera-Rhopalocera. 1 (texto), p.122-140; 2 (suppl.), p.664-666; 3, pls 12-15, 107 (figs 17-18). Taylor \& Francis.

Godman, F.D. \& O. SALvin. 1891, p. 96-110. In: E. Whymper. Travels amongst the Great Andes of the Equator. Suplementary appendix. (Lepidoptera, Rhopalocera). London, J. Murray.

Handlirsch, A. 1925. Geschichte, Literatur, Technik, Palaeontologie, Phylogenie, Systematik, p. 852-941, figs 747-841. In: C. SCHROEDER. Handbuch der Entomologie. 2. Jena, Fischer.

HARVEY, D.J. 1991. Higher classification of the Nymphalidae, p. 225 -273. In: H.F. NiJHout (Ed.). The development and evolution of butterfly wing patterns. Washington, DC, Smith. Ser. Comp. Evolutionary Biol., 297p.

HAYWARD, K.J. 1951. Catálogo sinonímico de los ropalóceros argentinos excluyendo "Hesperiidae". Acta Zool., Tucumán, Lilloana 9: 375-393.

-1954. Catálogo Sinonimico de Ropaloceros Argentinos, escluyendo Hesperidos (primer suplemento). Acta Zool. Lilloana, Tucumán, 14: 353-374.

- 1973. Catálogo de ropalóceros argentinos. Op. Lilloana 23: 1-318.

HeMming, F. 1941. The dates of publication of the several portions of Doubleday (E.) "Genera od Diurnal Lepidoptera" and in the continuation there of by Westwood (J.O.). Jour. Soc. Bibliogr. Nat. Hist., London 1: 447-464.

1967. The generic names of the butterflies and their type-species (Lepidoptera:Rhopalocera). Bull. Brit. Mus. (Nat.Hist.), Ent. (Suppl. 9): 1-509.

HEPPNER, J.B. 1982. Dates of selected Lepidoptera literature for the western hemisphere fauna. Jour. Lep. Soc., Lawrence, 36 (2): 87-111.

HePpNER, J.B. \& G. LAMAs. 1982. Acronyms for World Museum Collections of Insects, with Emphasis on Neotropical Lepidoptera. Bull. Ent. Soc. Amer. 28 (3): 305-315.

Hering, M. \& W. Hopp. 1925. Eine Sammelausbeute des Herrn Werner Hopp aus dem Chocó Kolumbiens. Dtsch. ent. Ztschr. Lep. Iris, Dresden, 39: 181-207.

HERRICH-SCHÄFFER, G.A.W. 1864. Prodromus systematis lepidopterorum. Versuch einer systematischen Anordnung der Schmetterlinge. Corr.- Blat zool.- miner.Ver. Regensb. 18 (7/8): 89-112, (9): 123-136, (10): 148-152.

HEwitson, W.C. 1869. Remarks on and descriptions of new species of butterflies collected by Mr. Buckley in Ecuador. Equat. Lep. 4: 32.

HinTON, H.E. 1946. On the homology and nomenclature of setae of lepidopterous larvae, with some notes on the phylogeny of Lepidoptera. Trans. R. Ent. Soc. London 97: 1-37.

HÜBNER, J. 1901-1906. Sammlung exotischer Schmetterlinge. Vol.I: VI p+pls 1-213; Vol.II: IVp.+pls 214-438; Vol. III: III+172p.+pls 439-491. Brussels, Reed., W.F. Kirby, Verteneuil \& Desmet.

KESSELRING, J. \& H. EBERT. 1979 [1982]. Relação das borboletas encontradas na "Mata do Buraquinho", João Pessoa, Estado da Paraíba, Brasil. Rev. Nordest. Biol., João Pessoa, 2 (1/2): 105-118.

KIRBY, W.F. 1871. A Synonymic Catalogue of Diurnal Lepidoptera. London, Voorst, 690p.

. 1877. A Synonymic Catalogue of Diurnal Lepidoptera, Suppl., p. 691-884. London, Voorst.

KIVIRIKKo, E. 1936. Beobachtungen über die Tagfalterfauna (Lep., Diurna) des Territoriums Misiones (Rep. Argentina) in der Zeit 5 V. - 20.VI.1928. Ann. Ent. Fenn., Helsinki, 2: 49-63. 
KöHLER, P. 1923. Fauna Argentina. Lepidoptera e collectione Alberto Breyer. I Theil: Rhopalocera, Systematischer Katalog und Studien, Berichtingungen u. Neubeschreibungen. Ztschr. wiss. Insekt.- Biol., Berlin, 18 (12), Sonderbeilage, 34p.

LAmAS, G. 1969. Lista de ropalóceros (Lepidoptera) peruanos citados em la obra "Die Gross-Schmetterlinge der Erde" de Adalbert Seitz. Biota, Lima, 7 (58): 265-38.

- 1981. La fauna de mariposas de la Reserva de Tambopata, Madre de Dios, Perú (Lepidoptera, Papilionoidea y Hesperioidea). Revta Soc. Mex. de Lep. 6 (2): 23-40.

- 1985. Los Papilionoidea (Lepidoptera) de La Zona reservada de Tambopata, Madre de Dios, Perú. I. Papilionidae, Pieridae y Nymphalidae (en parte). Revta Peruana Lep. 27: 59-73.

Lamas, G.; R. Robbins \& D. HaRvey. 1991. A preliminary survey of the butterfly fauna of Pakitza, Parque Nacional Del Manu, Peru, with an estimate of its species richness. Publ. Mus. Hist. Nat. UNMSM, Lima, 40: 1-19.

Lamas, G.; R. RobBins \& W. Field. 1995. Bibliography of buttterflies. Na annotated bibliography of the Neotropical Butterflies and Skippers (Lepidoptera: Papilionoidea and Hesperioidea). In: J.B. HEPPNER. (Ed.) Atlas of Neotropical Lepidoptera 124. Gainesville, Scientific Publishers, XIV+ $463 p$.

LEWIS, H.L. 1973. Butterflies of the World. Chicago, Follett. XVI+312p..

- 1975. Las Mariposas del Mundo. Barcelona, Ed. Omega S.A., 312.

MAES, J.M. 1999. Insectos de Nicaraguá. 3. Nicarágua, Imprenta Print, 1898p.

MAZA E., R.G. DE LA. 1987. Mariposas mexicanas. Guia para su colecta y determinación. México, Fondo de Cultura Económica, 304p.

Maza E., R.G. DE LA \& J. DE la MAZA. 1993. Mariposas de Chiapas. México, Gobierno del Estado de Chiapas, 224p.

MÉNÉTRIÉs. E. 1855. Enumeratio Corporum Animalium Musei Imperialis Academiae Scientiarum Petropolitanae. Classes Insectorum, Ordo Lepidopterorum. Pars.I. Lepidoptera Diurna. Catalogue de la Collection Entomologique de l'Académie Imperiale des Sciences de St.Pétersbourg. Petropoli, $97 \mathrm{p}$.

MielKe, O.H.H. 1995. Revisão de Elbella Evans e gêneros afins (Lepidoptera, Hesperiidae, Pyrrhopyginae). Revta bras. Zool. 11 (3): 395-586. [1994]

Mielke, O.H.H. \& M.M. Casagrande. 1998. Papilionoidea e Hesperioidea (Lepidoptera) do Parque Estadual do Morro do Diabo. Teodoro Sampaio, São Paulo. Revta bras. Zool. 14 (4): 967-1001.

Miranda Ribeiro, V. 1931. Lepidópteros de Matto Grosso. Material colligido pelos senhores General Candido Rondón, Prof. Alípio de Miranda Ribeiro e Emil Stlle. Bol. Mus. Nac. Rio de Janeiro 7 (1): 31-52.

Mosher, E. 1969. Lepidoptera Pupae. Five collected works on the Pupae of North American Lepidoptera. East Lansing, Michigan, Entomological Reprint Specialists, 323p.

MÜLLER, W. 1886. Südamerikanische Nymphalidenraupen. Versuch eines natürlichen Systems der Nymphaliden. Zool. Jahrb. Syst. 1: 417-678.

NICULESCU, E.V. 1972. La terminologia delle armature genitali nei Lepidotteri. Definizioni e Sinonimie. Boll. Ass. Rom. Ent., Roma, 27 (3, 4): 33-44.

— 1972-1983. L'armure génitale chez les lépidoptères. Bull. Soc. Ent. Mulhouse (Supl.): $1-128$.

Pagenstecher, A. 1909. Die geographische Verbreitung der Schmetterlinge, p. 360-419. Jena., Gustav Fischer.

Penz, C.M.; A. Aiello \& R.B. SRygley. 2000. Early stages of Caligo illioneus and Caligo idomeneus (Nymphalidae, Brassolinae) from Panamá, with remarks on larval food plants for the subfamily. Jour. Lep. Soc. 53 (4):142-152. [1999]

Peracchi, A. et al. (85 autores) 1998. In: H. DE G. Bergallo; C.F.D. DA Rocha; M. van Sluys; M.A. dos Santos Alves; T.P. Moulton \& K.T. DE FonseCa (Eds). Lista das espécies ameaçadas de extinção do Estado do Rio de Janeiro. Diário Oficial Estado Rio de Janeiro 24 (102), Part I, p. 9-16. 
Peterson, A. 1962. Larvae of Insects. Part I (Lepidoptera and Hymenoptera). Ohio, Columbus, 315p. Piñas Rubio, F.S.J. \& I. Manzano P. 1997. Mariposas del Ecuador. 1. Géneros. Quito, Pontificia Universidad Católica del Ecuador, 114p.

Podtiaguin, B. 1944. Notulae Entomologicae. Revista de la Sociedad Cientifica del Paraguay. Asunción, 4 (4): 3-24.

RichelmanN, G. 1889. Die Verbreitung der Rhopalocera in den verschiedenen Faunengebieten und einige Eigenthuemlichkeiten derselben. Tagebl. Dtsch. Naturf. Versamml. 61: 66-69.

Robbins, R.; G. Lamas; O.H.H. Mielke; D. Harvey \& M.M. Casagrande. 1996. Taxonomic composition and ecological structure of the species-rich butterfly community at Pakitza, Parque Nacional del Manu, Peru, p. 217-252. In: D. Wilson \& A. Sandoval (Eds). La Biodiversidad del Sureste del Peru: Manu, Biodiversity of Southeastern Peru. New York, Oxford Univ. Press, 679p.

RöBER, J.K.M. 1929. Ueber einige exotische Falter. Int. Ent. Zeitschr. 23 (27): 323-327.

Schaus, W. 1902. Description of new American butterflies. Proc. U.S. Nat. Mus. 24 (1262): 383-460.

SCUDDER, H.H. 1875. Historical sketch of the names proposed for butterflies; a contribution to systematic nomenclature. Proc. Amer. Ac. Arts \& Sci., Boston, (2) 10: 91-293.

SEITZ, A. 1890. Die Schmetterlingswelt des Monte Corcovado. Stett. Ent. Ztg. 51: 2-5, 28-35, 89-99, 258-266.

- 1928. Das System der Schmetterlinge. IV. Die Satyromorphen. Ent. Rdsch., Stuttgart, 45: 3-4, 8-10, 14-16, 20, 23-24, 27, 31, 34-35.

Silva, G.A.; C.R.Gonçalves; D.M. Galvão; A.J.L. Gonçalves; J. Gomes; M.N. Silva \& L. Somoni. 1967-1968. Quarto. Cat. Ins. Viv. Plant. Brasil 1 (1), p. I-XIII+1-422 (1967); 1 (2), p. 423-906 (1967); 2 (1), p.V-XXVI+1-622 (1968); 2 (2), p. 1-265 (1968). Rio de Janeiro, Laboratório de Patologia Vegetal.

SMART, P.E. 1976. The illustrated encyclopedia of the butterfly world in color. London, Hamlyn, 275 p.

Staudinger, O. 1887. Exotische Tagfalter. In: O. Staudinger \& E. Schatz. Exotische Schmetterlinge 1, 333p.

STEHR, F.W. 1987. Order Lepidoptera, p. 288-596. In: F.W. STEHR (Ed.). Immature Insects. Dubuque, Kendal,/Hunt, 750p.

Stichel, H. 1904. Lepidoptera, Rhopalocera, Fam. Nymphalidae, Subfam. Brassolinae. In: P. WYTSMAN (Ed.). Genera Insectorum. 20. Editor Brüssel, 48p.

— 1909. Brassolidae. Das Tierreich, Berlin, 25: XIV+244p (reedição de 1965, Verlag J. Cramer, Weinheim).

- 1916. Neues über Genus Narope West. Neue Beitr. syst. Insek. Berlim, 1 (1): 7-8.

1925. Zur Systematik der Brassolidae (Lep. Rhop.). Neue Beitr. syst. Insek. Berlin, 3: 58-69.

1932. Lepidopterorum Catalogus 51, Brassolidae. Berlin, W. Junk, 115p.

TALBot, G. 1928. List of Rhopalocera collected by Mr. C.L. Collenette in Matto Grosso, Brazil. Bull. Hill Mus., London, 2: 192-220.

Tessmann, G.T. 1928. Neue Schmetterlinge aus Ostperu. Mitt. zool. Museum Berlin 14 (1): 115-130. URICH, F.C. \& T.C. EMmEL. 1991. Life histories of Neotropical Butterflies from Trinidad. 5. Dynastor darius darius (Lepidoptera: Nymphalidae: Brassolinae). Trop. Lep. 2 (2): 145-149.

VÉlez, J.H. \& J.A. Salazar. 1991. Mariposas de Colombia. Bogotá, Villegas Editores, 168p.

WALLACE, A.R. 1876. The geographical distribution of animals. With a study of the relations of living and extinct faunas as elucidating the past changes of the earth's surface. London, Macmillan. Vol. 2, IX+607p.

ZIKÁN, J.F. 1920. Biologische Beiträge zur Schmetterlingsfauna Brasiliens. Ztschr. Dtsch. Ver. Wiss. Kunst., São Paulo, 1: 145-157.

ZIKÁN, J.F. \& W. ZIKÁn. 1968. Insecto-fauna do Itatiaia e da Mantiqueira. III. Lepidoptera. Pesq. agropec. bras. 3: 45-109.

Recebido em 09.I.2001; aceito em 09.V.2002. 